UNIVERSIDADE DE SÃO PAULO

FACULDADE DE FILOSOFIA, LETRAS E CIÊNCIAS HUMANAS

DEPARTAMENTO DE GEOGRAFIA

PROGRAMA DE PÓS GRADUAÇÃO EM GEOGRAFIA HUMANA

\title{
A PRODUÇÃO DO LUGAR NA PERIFERIA DA METRÓPOLE PAULISTANA
}

\section{Fabiana Valdoski Ribeiro}

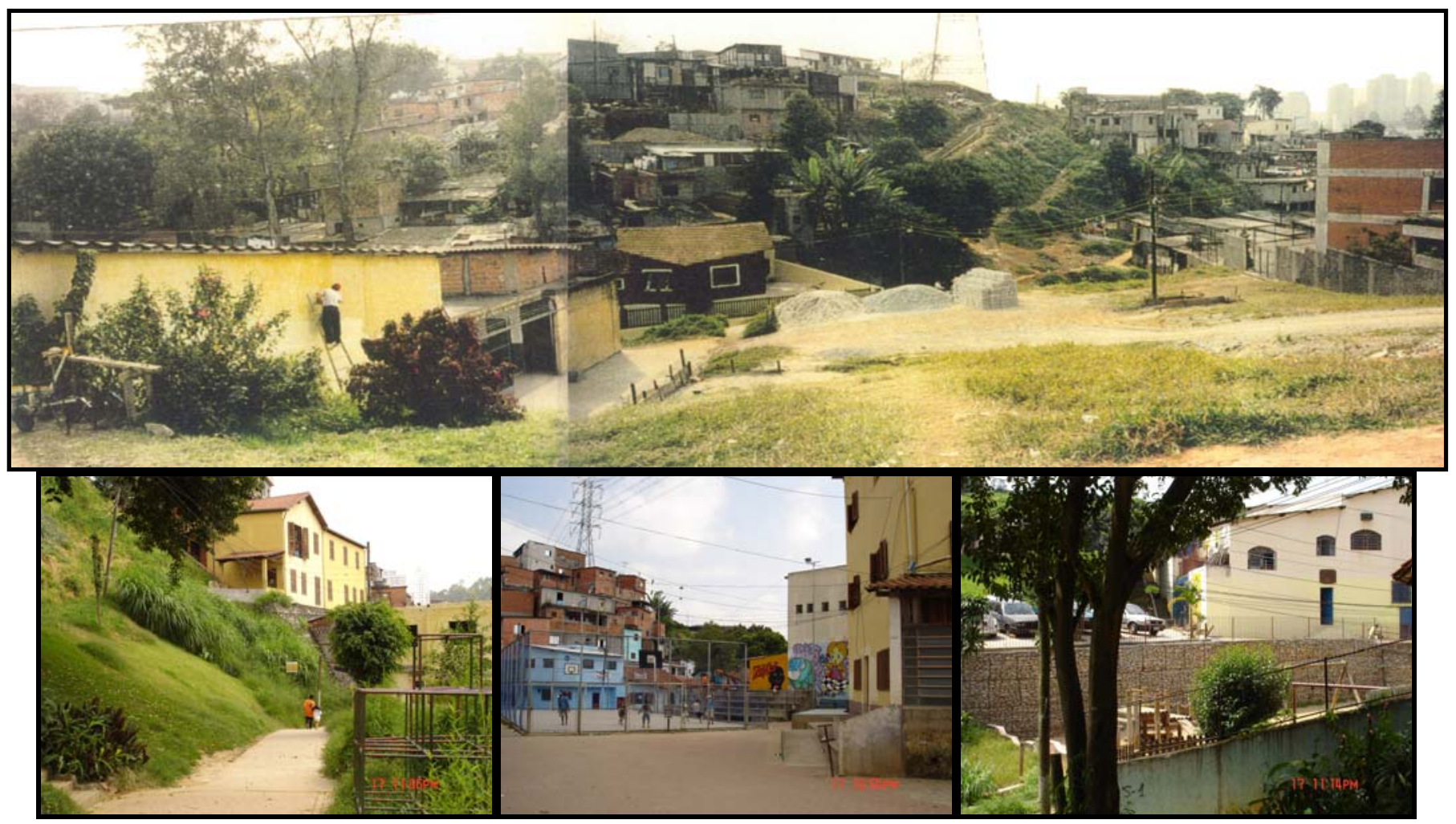

Orientadora: Prof ${ }^{a}$ Dr $^{\mathrm{a}}$ Ana Fani Alessandri Carlos

SÃO PAULO

2007 


\section{UNIVERSIDADE DE SÃO PAULO \\ FACULDADE DE FILOSOFIA, LETRAS E CIÊNCIAS HUMANAS \\ DEPARTAMENTO DE GEOGRAFIA \\ PROGRAMA DE PÓS-GRADUAÇÃO EM GEOGRAFIA HUMANA}

\section{A PRODUÇÃO DO LUGAR NA PERIFERIA DA METRÓPOLE PAULISTANA \\ Fabiana Valdoski Ribeiro}

Orientadora: Prof ${ }^{\mathrm{a}}$ Dr $^{\mathrm{a}}$ Ana Fani Alessandri Carlos

Dissertação de Mestrado apresentada

ao Programa de Pós-Graduação em Geografia Humana do Departamento de Geografia da Faculdade de Filosofia, Letras e Ciências Humanas da Universidade de São Paulo, para obtenção do título de Mestre em Geografia. 


\section{Agradecimentos}

Muitos amigos, pesquisadores e professores fizeram parte desta pesquisa de mestrado, seja por meio de colaborações acadêmicas, seja através do apoio contínuo na vida, em parte, solitária do pesquisador. Agradeço-os pelas reflexões, pelas conversas, pelos apoios e a possibilidade de construir amizades ao longo do caminho da pós-graduação e consolidar meu objetivo de tentar produzir um trabalho que busque uma sociedade pautada na coletividade.

Começo meus agradecimentos por minha mãe Elza e meu pai Manoel, sempre lutadores do povo, uma no “chão” da escola pública e outro no "chão” de fábrica. Foram eles que me proporcionaram a vontade de construir um mundo justo a partir de suas próprias experiências de vida. São estas experiências de meus pais que estão atreladas a outro grupo importante para minha trajetória, o grupo formado pela antiga organização de esquerda chamada Ala Vermelha, principalmente à Maria Luiza, Maria Lucia, Delmar, Hamilcar.

Na universidade destaco a importância do papel do Prof ${ }^{\circ}$ Ariovaldo Umbelino de Oliveira, que me proporcionou a entrada no mundo da pesquisa. À Prof ${ }^{a}$ Arlete Moyses Rodrigues, que ao vê-la no Encontro Nacional dos Estudantes de Geografia (2000) me permitiu vislumbrar a possibilidade de construção de uma geografia próxima dos movimentos sociais.

Com muito carinho, agradeço meu grupo de pesquisa formado pela Camila, Sávio, Danilo e Rafael, no qual começamos o nosso percurso no ano de 2001, orientados desde esta época pela Prof ${ }^{o}$ Ana Fani. Eles serão sempre meus eternos companheiros de pesquisa, de encontros, de projetos e o que pudermos fazer no futuro.

A minha orientadora, Prof ${ }^{a}$ Ana Fani, merece um agradecimento especial, por ela ser a professora que me convenceu a continuar na geografia devido a sua paixão em sala de aula, bem como a atenção que prestou a um grupo de alunas que estavam com muita vontade de aprender geografia urbana no ano de 1999. A Prof ${ }^{a}$ Fani nos mostra a possibilidade de fazer uma geografia radical, que tem por base o questionamento dos rumos desta sociedade.

Agradeço a todos da Favela Monte Azul e da Associação Comunitária Monte Azul que me concederam entrevistas e conversas, e me permitiram participar de encontros e construir minha interpretação a respeito deste lugar na metrópole. Destaco o grupo de teatro por meio do Cido (coordenador), Jefferson (pessoa que sempre esteve ao meu 
lado na pesquisa), Rosana e Igor. Em relação ao processo de “urbanização da favela” tive a oportunidade de conhecer e conversar com Seu Paulo, pessoa muito generosa e disposta a apresentar as melhorias existentes na favela. A arquiteta Vânia Ribeiro também foi uma pessoa fundamental para compreender o processo de "urbanização", me levando para as vistorias da obra na favela.

Neste percurso também preciso fazer menção ao nosso Laboratório de Geografia Urbana (Labur), com os amigos e grupos de estudos fundamentais a formação de qualquer estudante. São eles a Prof ${ }^{\mathrm{a}}$ Margarida, Prof ${ }^{\mathrm{a}}$ Amélia e Prof ${ }^{\mathrm{a}}$ Glória, a Flor (técnica do laboratório), Frederico, Isabel Alvarez, André Baldraia, Renata, Júnior, Flávia, Daniel (também pela tradução do resumo), Flávia, Paolinha, Felipe, Júlio entre outros que encontramos neste lugar de sociabilidade da universidade.

Agradeço aos Professores Cleide Rodrigues, Marisia Buitoni, Regina Bega, Rita de Cássia e Mônica Arroyo.

Aos mapas agradeço a André Gonçalves.

Aos amigos de vida, Luiz Fernando, Mauricio, Lea, Alexandrinho Linares, Malu D’Alessandro, Linconl Secco, Adolar, Andrezinho (Viterbo), Viviane, Rosana, Débora, Luciana Dias, aos participantes da Articulação Pelo Direito à Cidade e da Consulta Popular.

Por fim, agradeço ao apoio financeiro concedido pela Fundação de Amparo à Pesquisa de São Paulo, na forma de bolsa de mestrado, bem como ao meu parecerista que acompanhou o percurso da pesquisa e sugeriu alguns percursos para serem realizados. 


\section{RESUMO}

A problemática urbana sobre a qual nos debruçamos na presente pesquisa referese aos processos de degradação da vida dos habitantes da metrópole, não apenas material, mas, sobretudo, resultante do empobrecimento das possibilidades de apropriação dos lugares da cidade. Tal apropriação se reduz, dialeticamente, pelas estratégias de dominação do espaço, que impõem normas ao uso do espaço pelos habitantes como condição necessária a um espaço produto, condição e meio da acumulação capitalista. Todavia, a normatização da vida pelo regramento do uso do espaço não se realiza sem conflitos. A população urbana, nos momentos da vida cotidiana, transgride-a constantemente como meio de sobrevivência a uma cidade produzida sob a égide capitalista, que possui como centro a acumulação do capital, em detrimento da reprodução da vida.

É nesta perspectiva de desvendar as estratégias de normatização do uso e as transgressões diante o processo de dominação do espaço que a pesquisa se insere, tratando de compreender a produção de um lugar na metrópole paulistana, que se apresenta contraditoriamente como um espaço de normatização e transgressão na medida em que se constituiu como uma centralidade na periferia.

Esta reflexão se construiu a partir do conhecimento dos sujeitos que produziram o espaço da Favela Monte Azul - zona sul do município de São Paulo - destacando as ações de uma organização não governamental chamada Associação Comunidade Monte Azul, por entender seu papel de destaque na produção da singularidade desta favela diante as demais da metrópole. Para tanto, analisamos as bases de sua matriz discursiva, as estratégias e ações e, principalmente, as articulações entre os sujeitos existentes na favela por meio do processo de "urbanização da favela” e das atividades culturais teatro.

A hipótese orientadora da pesquisa fundamenta-se, portanto, na idéia de uma urbanização que aprofunda a degradação da vida, produzindo tensões e conflitos ainda mais violentos que podem impedir a reprodução das relações de produção, levantando “barreiras” ao processo de acumulação. Para não interromper o ciclo, uma das estratégias utilizadas é a dominação do espaço pela territorialização de instituições na periferia, que levam a cabo as normas elaboradas pela ordem distante (Estado/empresas privadas). Estas instituições, como as organizações não governamentais, tentam diluir as 
formas de organização e participação popular conforme introduzem a população às normas da cotidianeidade, isto é, às normatizações do uso através da legitimidade dada pela forma da propriedade e gestão dos serviços prestados. Contudo, essas mesmas instituições, na medida em que “absorvem” os conflitos, encontram-se em uma crise de sua própria reprodução.

Degradação - normatização - uso - dominação/apropriação do espaço - segregação sócio-espacial - centralidade na periferia - territorialização - instituições

\section{ABSTRACT}

The urban problematic into which we delve in this research is concerned with the process of degradation of metropolitan life resulting from shrinking possibilities of place appropriation in the city. This appropriation is dialectically constrained by the strategies of spatial domination, which impose rules to people's use of space as a necessary prerequisite to a space that is means, condition and product of capital accumulation. Nevertheless, the regulation of life through the control of spatial uses does not occur without contradiction. In everyday life, people are often violating these

rules as a means of surviving in a city produced under capital's command and organized to meet the requirements of capital accumulation, instead of those of the reproduction of life.

This research is, therefore, carried out with the aim of uncovering the strategies of regulation of uses and the transgressions that arise in the face of spatial domination, attempting to understand the production of a specific place in the city of São Paulo. This place presents itself contradictorily as a space of regulations and a space of transgressions, so long as it has become a centrality on the periphery.

We derived such considerations from an understanding of the subjects that have produced the space of Monte Azul slum (southern area of the city of São Paulo), focusing on the actions of a non-governmental organization named Associação Comunidade Monte Azul (ACMA), which we considered to have a significant role in shaping the uniqueness of this place compared to others. We examined, therefore, the foundations of ACMA's discursive matrix, its strategies, its actions and the articulation 
of the subjects through the process of "slum urbanization" and through cultural activities (theatre).

The guiding hypothesis of our research rests upon the assumption of an urbanization that intensifies the degradation of life, inevitably creating tensions and sparking ever more violent social conflicts that could pose threats to the reproduction of relations of production and erect barriers to accumulation. One of the strategies pursued in order to defend accumulation is the domination of space through the territorialization of institutions in the urban periphery. These institutions, such as non-governmental organizations, impose the rules set out by the distant order (State/corporations) and try to discourage collective participation and organization, all the while introducing people to the rules of everydayness, that is, to the regulation of uses through the legitimacy conferred by the type of propriety and management of the services offered. These very same institutions, though, as long as they "internalize" conflicts, find themselves sunk in a crisis of reproduction.

Degradation - regulation - use - spatial domination/appropriation - sociospatial segregation - centrality on the periphery - territorialization - institutions 


\section{Índice}

Resumo/Abstract

$\begin{array}{lll}\text { Agradecimentos } & \text { IV }\end{array}$

$\begin{array}{ll}\text { Introdução } & 01\end{array}$

Os conflitos decorrentes da tendência À degradação da vida apreendidas no lugar $\quad 03$

$\begin{array}{ll}\text { O percurso proposto } & 10\end{array}$

A urbanização da Favela e o Núcleo Teatral: a vida vista pelas transgressões 11

$\begin{array}{ll}\text { O movimento da exposição } & 15\end{array}$

Capítulo I - As Continuidades e Rupturas na Produção do Lugar 17

A morfologia da favela Monte Azul $\quad 21$

Os momentos de produção do lugar: A - A formação da Favela Monte Azul 25

B- O momento de produção da Favela Monte Azul: A chegada dos antroposóficos 34

C -O momento de reprodução da Favela Monte Azul: crises e territorialização da Associação

Comunitária Monte Azul $\quad 41$

A morfologia contígua ao Lugar 46

Capítulo II - Da Periferização às Centralidades na Periferia 58

O Espaço condição, meio e produto da reprodução da sociedade 63

A mercadoria e o espaço-mercadoria $\quad 64$

$\begin{array}{ll}\text { Apontamentos sobre a segregação sócio-espacial } & 71\end{array}$

Uma leitura possível da dominação e apropriação do espaço 74

Capítulo III - A Territorialização da Associação Comunitária Monte Azul 82

As organizações não governamentais - Novos sujeitos em cena?

A Associação Comunitária Monte Azul e um panorama da matriz antroposófica 90

A estrutura da Associação Comunitária Monte Azul e a gestão dos serviços 97

Mantenedores e fluxo de capital 105

$\begin{array}{ll}\text { Um exemplo de atuação } & 109\end{array}$

$\begin{array}{ll}\text { A crise no período de reprodução do Lugar } & 110\end{array}$

A morfologia da favela: Os prédios da ACMA e o Centro Cultural 120 
A política de “urbanização da favela” Monte Azul 132

Favelas, urbanização e movimentos sociais 133

A favela Monte Azul e o processo de “urbanização da favela” 139

A atuação da ACMA nas intervenções da favela 139

As conquistas na produção do lugar 147

O aumento dos preços das casas na favela 153

A disputa pelo espaço de uso: fragmentação do espaço? 158

Os limites das ações assistencialistas 162

A atividade teatral na Associação Comunitária Monte Azul 165

Os conflitos de concepções do “Fazer” teatro 167

A nova fase do núcleo teatral 169

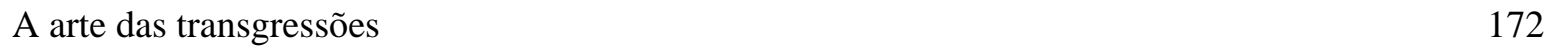

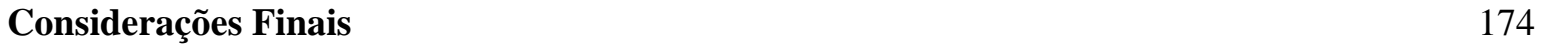

$\begin{array}{ll}\text { Bibliografia } & 176\end{array}$

$\begin{array}{ll}\text { Anexos } & 183\end{array}$ 


\section{Introdução}

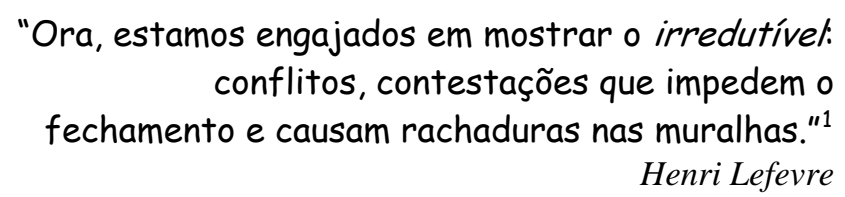

A proposta da pesquisa fundamenta-se na procura daquilo que resiste e transgride a lógica da redução das possibilidades de apropriação e uso da metrópole pelos habitantes que nela vivem. A resistência e a transgressão ${ }^{2}$ realizada pelos milhares de habitantes expropriados (dos direitos, da vida, do trabalho, da terra) foram a princípio apreendidas como os elementos reveladores das contradições dos conteúdos da urbanização contemporânea, a partir do choque entre a reprodução ampliada do capital, que mobiliza os momentos de trabalho, de lazer e da vida privada da sociedade visando a realização plena da acumulação, e os momentos de reprodução da vida dos habitantes da metrópole, que, por sua vez, se reproduzem por meio de transgressões, como condição necessária frente a tendência à degradação da vida.

A potência de ambos os conceitos, resistência e transgressão, reside no fato destes conterem os conflitos, latentes ou não, da reprodução da sociedade em sua totalidade, as formas distintas de apreensão de elementos para esta reprodução pelas classes que a compõem, com seus jogos de estratégias e ações, que se revelam concretamente em práticas sócio-espaciais.

A tentativa da busca pelas resistências e transgressões na metrópole surgiu como a porta de entrada para compreensão das formas de dominação pelas quais a produção do espaço capitalista é regido, pois essas ações fazem parte do questionamento do processo hegemônico em curso. Muitas vezes porém, o que aparece sob a forma de transgressão e resistência ratifica a expropriação ou exploração através da cooptação dessas ações pelos sujeitos implicados na lógica da acumulação, revelando, assim, um grau de perversidade ainda maior do processo. Esta foi a realidade com a qual nos deparamos ao longo da pesquisa, e analisando uma favela que alcançou inúmeras conquistas relacionadas aos aspectos infra-estruturais, construídas a partir das histórias

\footnotetext{
${ }^{1}$ Lefevre. Henri, A vida cotidiana no mundo moderno, Editora Ática, pg.84

${ }^{2}$ A transgressão é compreendida nos termos que Henri Lefebvre elabora como elementos reveladores do movimento tendencial, mas que somente elas não bastam para uma transformação das estruturas da sociedade. Ela se afasta do termo resistência, pois concebemos a resistência como uma ação que contem estratégias e táticas inseridas dentro de um projeto político e social.
} 
de lutas dos movimentos sociais existentes na metrópole, chegamos nas formas sutis de dominação do espaço efetivadas por sujeitos que realizam a lógica hegemônica através de ações assistencialistas. E, de fato, tais relações povoaram grande parte das organizações existentes na história da metrópole paulistana.

Por outro lado, uma metrópole como São Paulo, centro de poder econômico, e que no início do século XXI continua a representar a cidade eleita para o circuito mundial, a resistência e a transgressão são condições necessárias para a sobrevivência dos trabalhadores, produzindo organizações que não estão pautadas pelo assistencialismo, ou ainda, pelo clientelismo. É em São Paulo que estão localizadas as sedes dos maiores movimentos sociais urbanos, principalmente aqueles que lutam por moradia, transporte e saneamento básico ${ }^{3}$, bem como é nela que se encontram os sindicatos mais ativos. Além disso, a cidade agrupa também as secretarias nacionais de movimentos sociais ditos rurais, como por exemplo, o MST (Movimento dos Trabalhadores Rurais Sem Terra) ou o MLST (Movimento de Libertação dos Sem Terra).

Todavia, constatamos, neste princípio do século XXI, uma crise das organizações populares urbanas, que pode ser observada a partir do empobrecimento da participação direta das mesmas. A questão que nos cabe, então, é compreender qual é ou quais seriam os elementos reveladores do fundamento desse processo que transparece atualmente.

Muitos autores atribuem esta realidade à institucionalização ${ }^{4}$ dos movimentos, que hoje atuam junto a parlamentares e secretarias de governo, fato decorrente do processo de democratização do país pela via representativa. Outros focam suas análises no aparecimento de outras formas de organização, como por exemplo, as organizações não governamentais, que substituem os espaços de sociabilidade e das experiências de politização e iniciam uma burocratização das formas de luta. Contudo, todos convergem para um mesmo prisma, o de que há uma profunda crise das formas de organização e mobilização da população urbana, que os fragiliza e produz um terreno fértil para as estratégias de dominação.

\footnotetext{
${ }^{3}$ Eis alguns exemplos, Central dos Movimentos Populares - CMP, União Nacional por Moradia PopularUNMP, Movimento Nacional de Luta pela Moradia - MNLM e, mais recentemente, Coordenação dos Movimentos Populares - CP.

${ }^{4}$ Eder Sader termina seu livro destacando este ponto e, de fato, durante as aulas de pós-graduação ministradas pelo Prof. Dr. Lucio Kowarick, tais questões tiveram centralidade no debate, inclusive destacando-se a diminuição de estudos na academia sobre os movimentos sociais.
} 
Claro que associado a tais processos, estão implicadas determinações de ordem econômica, política e social, observáveis principalmente no início da década de 90, com o redirecionamento dado pelos impactos da reestruturação produtiva, o novo papel do Estado no que tange as políticas sociais, e as formas violentas de criminalização daqueles que fazem parte de organizações populares. A crise nestas organizações, bem como na participação popular, desenha uma das facetas da problemática urbana neste princípio do século XXI, sinalizando o aprofundamento da degradação da vida dos habitantes da metrópole em suas três dimensões (social, político e econômico) e, a partir daí, compreendê-la tornou-se o objetivo amplo desta pesquisa.

A hipótese que orienta esta pesquisa fundamenta-se na idéia de que há hoje na metrópole um movimento tendencial ao empobrecimento das relações sociais, que se torna igualmente empobrecimento da vida na metrópole, reduzida ao ato do consumo e ao mundo privado. Esse processo se impõe pela redução das possibilidades de apropriação do espaço no âmbito do lugar, que aponta as perdas e os interditos constatados em São Paulo como um dos novos conteúdos da urbanização, fruto do momento de sua reprodução.

Este empobrecimento possui um sentido mais amplo do que aquele atribuído pelas precarizações das condições materiais. Ele se espalha por um campo mais vasto, submetendo o habitante da metrópole às segregações não apenas de ordem econômica, mas fundamentalmente, políticas e sociais.

Assim, na presente pesquisa, a intenção é compreender o empobrecimento da vida na metrópole e revelar as estratégias de dominação, que possui o espaço como condição central à realização do processo hegemônico.

\section{Os Conflitos Decorrentes da Tendência à Degradação da Vida Apreendidos no Lugar}

Do ponto de vista de uma leitura geográfica, na qual compreendemos o espaço como condição, meio e produto da reprodução da sociedade (como poderá ser visto no capítulo 2), verificamos as estratégias de classe ${ }^{5}$ que produz este mesmo espaço e quais

\footnotetext{
${ }^{5}$ A estratégia aqui apresentada é aquela efetuada no âmbito da prática, que comporta também o nível teórico, dos discursos, dos saberes, que muitas vezes legitimam os atos concretos. "La estrategia de clases trata de asegurar la reproducción de las relaciones esenciales a través de la totalidad del espacio.”Lefebvre, H. Espacio y Política, pp41, “Que se deve entender por estratégia? Uma noção corrente, a noção de 'relação de forças' não basta, pois não ultrapassa o nível da táctica. Em resumo, a Estratégia não é constituída nem por concepções admitidas por um 'sujeito' genial, o Chefe, nem pela aplicação pormenorizada dum sistema doutrinal pré-existente. Ela resulta de um encadeamento de acasos e de necessidades sempre particulares: as confrontações entre forças diversas e desiguais, repartidas por
} 
as tendências do processo de urbanização, bem como, os conflitos decorrentes da produção deste no atual momento histórico. Nestas últimas décadas, com o acelerado processo de urbanização, acompanhado pelo incremento de formas ainda mais sutis de exploração, ocorre um empobrecimento maciço da maioria da população, aprofundando a desigualdade da sociedade. Simultaneamente, a produção do espaço ganha ainda mais relevância enquanto instrumento e mediação de poder, pois ele se insere como objeto central utilizado para amenizar, controlar e oprimir a sociedade que exacerba as contradições.

Na perspectiva da crise das organizações e da participação popular, na qual o espaço adquire centralidade, a pesquisa de mestrado, que buscou a negatividade à tendência hegemônica, elegeu a favela Monte Azul, localizada na porção sul do município de São Paulo, como um lugar possível de compreender alguns dos conteúdos da dominação do espaço e das transgressões dos moradores diante desse processo.

A favela é tratada como referência de cultura e serviços públicos e, principalmente, um modelo de como é possível empreender uma melhor “qualidade de vida” a partir de ações de determinada organização não governamental (ONG). Sua morfologia demonstra uma singularidade impressionante se comparada com o restante das favelas paulistanas, assim como, as ações ali reunidas despertam a atenção de muitas instituições e mesmo de indivíduos atrelados aos trabalhos de cunho social, que vão visitá-la para conhecer todo o aparato divulgado pelas redes do terceiro setor ou por aqueles que a freqüentam.

Desse modo, por conter tal singularidade fundada nas melhorias infra-estruturais e reunir serviços escassos à periferia, ela se transformou em nosso objeto de estudo, buscando compreender os usos que a população fazia do espaço produzido, porque tal favela apareceu enquanto uma resistência à imposição da lógica da troca, na medida em que privilegiava o uso.

Neste percurso, descobrimos que as conquistas se realizaram pela mediação de um processo de intervenção política chamada “urbanização de favela”, calcado na concepção dos movimentos sociais, mas realizada na prática subvertendo os próprios

dois campos opostos (se houver três partidos em presença, a situação complexifica-se extraordinariamente). Os objetivos, os interesses, as vontades, as representações das diversas fracções empenhadas na luta, as concepções dos dirigentes, tudo isso desempenha o seu papel. A unidade teórica resultante dessas relações tomadas no seu conjunto, horizonte dos atos parciais, visão total inacessível enquanto tal a cada um dos participantes tomados separadamente e contudo possível/impossível dos seus pensamentos e consciências é a Estratégia no sentido de Clausewitz.” Lefebvre, H., A re-produção das relações de produção, pp. 90. 
princípios desta concepção. Por outro lado, nos ativemos às ações da área cultural, dando destaque ao grupo de teatro existente, pois esta atividade atribuiu tanto visibilidade deste lugar para o restante da metrópole, como também, destacou uma maneira de apropriação do espaço que contém a riqueza dos conflitos entre dominação e transgressões das normas impostas para o lugar. Além de atribuir esta visibilidade à Associação que as organizou, ambas as ações são relevantes mediações para explicar a metamorfose das práticas sócio-espaciais dos moradores.

No primeiro momento, a pesquisa de campo se enveredou pelo aprofundamento das ações da ONG Associação Comunitária Monte Azul, que gerencia todas as atividades existentes (ambulatório, creches, oficinas profissionalizantes, festas, etc.) e que teve e têm papel central na metamorfose da morfologia da favela. A princípio, esta ONG aparecia enquanto mediação para conhecer as práticas sócio-espaciais dos moradores, mas sua potência de reunir condições para além de equipamentos nos chamou a atenção e, deparamo-nos, então, com os mecanismos de gestão dos serviços e com a propriedade dos equipamentos e prédios existentes na favela. O debruçar-se sobre o estudo dessa organização não governamental revelou-se importante para destacar um aspecto da problemática urbana, nomeadamente, as formas de dominação e os conflitos da população que se encontra sob as normatizações das instituições.

A Associação Comunitária Monte Azul, portanto, se transforma em objeto de pesquisa para compreender sua estrutura e estratégias na produção daquele lugar em articulação com os (ou subordinação dos) moradores. À medida que realizávamos o trabalho de campo encontramos uma forma sutil de dominação do espaço, que transformava as melhorias conquistadas ao longo dos anos em uma forma de subordinação dos moradores.

Alcançávamos, assim, o descompasso entre morfologia e conteúdo das relações sociais, pois se a aparência morfológica demonstrava uma resistência ao processo de urbanização no mundo contemporâneo por permitir a produção de espaços de uso, ao nos aprofundarmos no conteúdo destas conquistas, defrontamo-nos com uma forma de segregação daqueles habitantes, que por sua natureza camufla as formas mais sutis de manutenção da reprodução das relações de produção, ou seja, as normas que empobrecem o uso e controlam a vida dos moradores. 
COLOCAR MAPA DE LOCALIZAÇÃO EM A3 
$\underline{\text { A análise da participação dessa instituição no processo de "urbanização da }}$ favela” e da forma como se realiza o trabalho cultural na área teatral colocam-se como o objetivo específico da pesquisa, por considerá-las mediações que revelam as sutis relações de manutenção da reprodução das relações de produção.

Conforme o desenvolvimento da pesquisa, deparamo-nos com uma das contradições centrais da produção do espaço urbano paulistano, que se agrava na medida em que se aprofundam os laços de dominação, calcados, principalmente, na escassez (da terra, dos serviços públicos, dos espaços de uso e lazer), produto e condição da segregação sócio-espacial. Essa contradição põe em primeiro plano o papel do espaço enquanto instrumento das estratégias de poder no mundo contemporâneo: a contradição apropriação e dominação do espaço, que pretendemos explicitar ao longo da exposição.

Cabe, inicialmente, considerar o caráter singular deste lugar, seja pela reunião de equipamentos, concentração de fluxo de verbas e pessoas, desde estrangeiros até usuários dos serviços oferecidos, seja pelo poder exercido pela própria instituição. Estas características dão a qualidade de uma centralidade possível na periferia em relação à metrópole e tal centralidade é compreendida por meio do significado de periferia e de como o espaço urbano é produzido. É nesta medida, que entendemos a periferia enquanto produto de uma lógica de centralizações (Rocha, 2000), a qual possui como fundamento a tríade homogeneização-fragmentação-hierarquização do espaço. É esta tríade que nos permite compreender a extensão da segregação sócio-espacial, porque, no movimento da realidade, produz-se estratégias de inclusão do espaço ao circuito da troca, homogeneizando-o sob a forma de mercadoria para se integrar ao mundo da racionalidade capitalista. Tal homogeneização forma centros que emitem as normas concebidas pelas determinações hegemônicas, hierarquizando os espaços "periféricos” a partir da atribuição de funções específicas que reforçam a integração ou desintegração ao circuito da troca. Através desta extensão, o espaço se estilhaça, torna-se fragmentado, já que na medida que se integra ao circuito da troca, o acesso se realiza pela mediação do dinheiro. É esta mediação que assegura o não acesso de todos à terra urbana, reforçando os laços de subordinação e aprofundando a contradição fundante da urbanização atual, que é a relação entre uso-troca. Segundo Botelho (2005)

“... a fragmentação é um instrumento de poder político, pois 'separa para reinar', transformando os membros da sociedade em indivíduos indiferentes 
entre si, unidos em grupos de interesses contrapostos, isolados por barreiras visíveis e invisíveis".

Essa centralidade, que se produz em parte pelas ações dos sujeitos e instituições atuantes na produção deste lugar na periferia, representa um "nó” das normas elaboradas por uma ordem distante, que se realiza no âmbito do lugar com características específicas. Estão implicados neste processo, os moradores da favela, a comissão de moradores, a Associação Comunitária Monte Azul, o Estado (representado pela Prefeitura de São Paulo, destacadamente), as empresas mantenedoras da instituição, além dos usuários da estrutura oferecida. Esses sujeitos criaram uma rede de estratégias, que dão uma especificidade ao lugar, como também, particularidades aos usos que seus habitantes fazem do espaço. Apresenta, também, o entrelaçamento dos moradores com instituições, demonstrando a dimensão da prática sócio-espacial permeada por determinações concebidas estranhamente ao modo de se apropriar do espaço em sua vida cotidiana, revelando a dominação enquanto norma e, assim, o conflito latente.

O movimento de centralização revela a territorialização ${ }^{6}$ de sujeitos para levar a cabo estratégias específicas. Na pesquisa, portanto, aparece e, é posto em relevo, a territorialização da Associação Comunitária Monte Azul internamente à Favela, que se aprofunda com a “política de urbanização” realizada no início dos anos 2000. A aparente aceitação desta territorialização, consentida e legitimada pelos moradores, é compreendida pelo fato destes últimos estarem imersos no processo de segregação sócio-espacial (o termo favela já nos aponta esta condição precária), produto da produção capitalista do espaço, que imprime uma perversidade ainda maior na conjuntura desenhada do início da década de 90.

O estudo da morfologia singular traz, também, um conteúdo específico, que aponta neste lugar a necessidade de compreender a segregação sócio-espacial para além da precariedade material, pois o espaço social segregado representa as fragmentações da vida que podem estar sob os véus das melhorias infra-estruturais.

\footnotetext{
${ }^{6}$ O conceito de territorialização é compreendido conforme a interpretação de Fernandes (1999), que se refere a Raffestin, "o território é um trunfo particular, recurso e entrave, continente e conteúdo, tudo ao mesmo tempo. O território é o espaço político por excelência, o campo da ação dos trunfos”. A territorialização destaca as relações de poder impressas materialmente no espaço. Na presente pesquisa verificamos a territorialização da ACMA a partir de seus prédios, nos quais se realizam as atividades conforme as normas de seu projeto. Na pesquisa de Fernandes, ele analisa a territorialização do MST a partir da conquista dos assentamentos.
} 
Desse modo, percebemos que nesta favela, na qual se conquistou imensas melhorias infra-estruturais, a segregação tornou-se de produto a condição de dominação desta mesma população mediada por normas de uma instituição como a Associação, na medida emque o risco de retorno à escassez dos serviços de educação e saúde, dos espaços de uso e lazer é uma ameaça e, fundamentalmente, a propriedade e gestão dos serviços estão nas mãos da Associação. A propriedade e a forma de participação dos moradores são centrais para se entender até que ponto a segregação à qual é submetida a maioria da população se transforma em instrumento de realização da segregação política dos indivíduos que lá vivem.

O processo de produção deste lugar, com as conquistas das melhorias infraestruturais, reafirmam normas assistencialistas e de dependência ao invés de se apresentar como processo de produção de um espaço a ser apropriado, um espaço de socialização, no qual poderia se transformar em um espaço de realização de experiências de politização.

A segregação seria, portanto, uma forma estrategicamente elaborada pelo saber e realizada na prática pelo poder político para dominar o espaço, e desse modo, tenta impedir as contestações, as ações organizadas da população, e por conseguinte, possui um caráter político que reforça a centralização exercida pelo centro de decisões.

Afirmamos, então, que a segregação enquanto condição se camufla em melhorias infra-estruturais, que são positividades no que diz respeito à vida de seus habitantes, mas que, ratifica as relações de poder e as formas de dominação em um período em que a reprodução das relações de produção se tornam centrais e o papel do espaço aparece em primeiro plano.

Isto nos leva a atentar para o fato de que os processos de produção deste lugar não se referem às formas de resistências na metrópole, e sim, às transgressões necessárias para a realização da reprodução da vida. Como dito anteriormente, as resistências são compreendidas como ações referendadas em um projeto político-social pautado no valor-de-uso, algo que não ocorre no lugar da cidade analisado. Referimonos, então, às transgressões, entendidas como ações inerentes a vida por esta permanecer subordinada às relações mercantilistas e da troca, mas que podem reforçar ou não os laços desta própria subordinação.

As transgressões se realizam a todo o momento nos planos da vida cotidiana, rompendo com as normas postas, mas não necessariamente contendo um outro projeto. As transgressões são contínuas, pois o processo de homogeneização e subordinação da 
vida também não é interrompido, sendo a todo instante posto em xeque pela prática sócio-espacial, já que a tendência hegemônica, isto é, da reprodução do capital, possui finalidades opostas às da vida. Diante das normatizações desta instituição localizada na favela, se realizam as transgressões por inúmeros caminhos, às vezes tortuosos, às vezes de modo questionador pelos moradores. Na pesquisa pudemos identificar tanto jovens que se integraram ao tráfico de drogas (até então ausente na favela devido a outras relações de poder existente dentro dela), quanto os que atuam no grupo de teatro, que questionavam as normas impostas pela concepção da instituição. Em relação a estes últimos, há a prática do ensaio de peças como “A balada de um palhaço” de Plínio Marcos, autor de peças que denunciam as mazelas da precariedade criada pela sociedade. Como o teatro é uma atividade interna à Associação, os conflitos se destacam pela forma de praticá-lo, e sua história é de embates com a direção geral da instituição, provocando dissoluções dos grupos ao longo dos anos. A prática do teatro nesta favela é um ótimo exemplo de transgressões que se realizam internamente às estruturas que ratificam os processos de dominação. Esta prática revela que não impera somente uma dominação sobre o espaço e as relações de passividade, mas que ela está sob constante disputa, em permanente conflito pela possibilidade de apropriação e são fundamentais para entender o movimento do processo, ou seja, para os sujeitos que realizam as estratégias hegemônicas apresenta-se como "barreiras" e para os moradores que se reproduzem tendo como referência o uso e não a troca representam a luta pela vida.

Ter como objeto a compreensão das práticas sócio-espaciais significa repensar o mundo contemporâneo em seu movimento, uma vez que o próprio objeto é móvel. Os conflitos e contradições, que constantemente ganham outros sentidos pela dinâmica dos embates dos sujeitos que usam e produzem o espaço da metrópole, são o cerne da prática sócio-espacial. Compreender estas práticas significa também uma possibilidade de escapar dos riscos das reduções sobre a realidade em modelos e sistemas teóricos fechados, que não consideram o processo enquanto movimento, e além do mais, tê-las como foco coloca em destaque um dos níveis negligenciados em grande parte nas pesquisas, que é o da vida cotidiana.

\section{O Percurso Proposto}

A Geografia ao objetivar compreender as contradições e conflitos da sociedade por meio da produção do espaço situando-o como condição e meio necessário de 
reprodução da sociedade em seus níveis econômico, social e político ${ }^{7}$, enveredou-se nas possibilidades de compreensão da prática sócio-espacial realizada pelos habitantes, e especificamente em nossa pesquisa, a da instituição que usa o espaço da favela para realização de seu projeto, neste caso, localizada na periferia da metrópole paulistana.

A prática sócio-espacial é apreendida por meio do desvendamento dos usos no plano do lugar, daí decorre considerar a vida cotidiana como nível fundamental da análise, introduzindo a necessidade de compreensão dos usos, que são as formas espaçotemporais concretas na produção e reprodução da vida e do lugar. Os usos que os habitantes realizam nos lugares da metrópole vão explicitando a própria produção destes lugares na indissociabilidade entre espaço e tempo (Carlos, 2001), como também as intervenções das estratégias dos sujeitos implicados e suas concepções que atravessam tais formas.

Assim, é a partir dos usos atuais - consolidação da morfologia da favela e da territorialização da Associação - que revelamos e caracterizamos, na primeira aproximação com o lugar, os sujeitos implicados em sua produção, dando visibilidade às ações da instituição Associação Comunitária Monte Azul, que pôde nos revelar as relações tecidas interna e externamente à favela, e desse modo, situamos os conflitos das estratégias da vida e da lógica do capital. É nesta medida que as categorias lugar, uso, e vida cotidiana se apresentam como centrais na análise dos novos conteúdos da urbanização.

Como mencionado, elegemos para a análise duas ações que aparecem como centrais e potentes no processo de intervenção na prática sócio-espacial, advindas de estratégias que transformaram profundamente os usos dos lugares pelos habitantes e a produção deste lugar específico. Tais ações aparecem como mediação, no plano da realidade, da contradição apropriação e dominação do espaço.

\section{"Urbanização da Favela" e o Núcleo Teatral: A Vida Vista pelas Transgressões}

A primeira ação a ser estudada refere-se à “urbanização da favela”, que possui um caráter mais abrangente, interferindo diretamente na produção do lugar. Este seria

\footnotetext{
${ }^{7}$ Carlos nos esclarece que,“O espaço geográfico não é humano porque o homem o habita, mas antes de tudo porque é produto, condição e meio de toda a atividade humana. O trabalho, como atividade do homem, tem um caráter intencional e voluntário, o que implica a transformação do objeto em algo apropriado; o processo produtivo é assim um processo de produção concreta, nascida do trabalho; uma resposta do homem as suas necessidades. A satisfação das necessidades de sobrevivência do homem e da reprodução da espécie coloca-se como condição do processo histórico.”, A (re)produção do espaço urbano, Edusp, São Paulo, 1994.pág. 33
} 
um exemplo da introdução de uma política pública, que transforma a morfologia da favela, e permite a produção de um espaço de uso, que amplia as possibilidades de apropriação dos moradores por meio da produção de uma ampla área de lazer, mas por outro lado, alavanca um processo de disputa entre os sujeitos ali presentes.

Uma política que tem sua origem nas reivindicações e ações dos movimentos sociais urbanos que questionavam a impossibilidade do acesso à terra urbana, a expulsão dos favelados de áreas que se integravam ao circuito produtivo, e denunciavam, nas estratégias e táticas de luta, a tendência da degradação da vida na cidade, por meio da constatação da desigualdade na paisagem que aparece como o modo mais imediato pelo qual o processo de segregação sócio-espacial se apresenta.

A análise do processo da urbanização da favela é potente, pois apresenta as diretrizes de uma política que foi conquistada e elaborada por movimentos sociais urbanos e que tem por finalidade a reprodução da vida e, portanto, a produção do espaço calcado nas possibilidades do uso e da apropriação, revelando também, as formas de inserção nas lutas da metrópole e apontando a organização da população e suas relações com a institucionalização.

Por outro lado, esta política mostra que as relações tecidas na sua realização estão permeadas pelas determinações do Estado, produzindo normas que não condizem com o projeto que os habitantes das favelas construíram, e muitas vezes reiterando os marcos da dominação do espaço pela equalização do desigual. Isto é, o Estado como único que detêm o poder de se sobrepor à propriedade privada do solo por um aparato legal, impõe suas normas de homogeneização ao espaço e esta homogeneização se apresenta como necessária para a realização das estratégias de dominação do espaço, ${ }^{8}$ quando este serve de instrumento político de determinada classe.

A “urbanização de favela”, portanto, aparece na Favela Monte Azul como uma forma de ampliação dos usos daquele lugar da metrópole, mas ao mesmo tempo, como introdução da dominação do espaço pelas regras e normas de uma ordem distante (instituições e Prefeitura), contribuindo para a territorialização da Associação Comunitária Monte Azul - ACMA. Essa territorialização fornece aos moradores usos que não existem na maioria das favelas e mesmo nos bairros da periferia paulistana, entretanto, tais usos estão subordinados ao projeto da própria ACMA. E é este projeto

\footnotetext{
${ }^{8}$ Lefebvre em seu livro intitulado A Respeito do Estado apresenta que o Estado possui uma simultaneidade, ou seja, ele ora se apresenta como representação da sociedade, ora ele é o instrumento político de uma classe. Neste momento se revela a desigualdade da sociedade.
} 
que se produz com referenciais externos à população residente, e se incorpora a ela por relações assistencialistas. Portanto, é a partir da análise do processo de "urbanização da favela”, que percebemos a articulação entre a organização dos moradores, a ACMA e o Estado.

Essa análise nos aproxima do significado da produção da norma como coação e ação da produção da cotidianidade ${ }^{9}$, que se instala programando e fragmentando os momentos da vida ${ }^{10}$, tratando-se de uma ação lógica e racional, inserida em estratégias de instituições como as das políticas públicas de modo geral.

O que marca um período diferenciado no plano da favela é a introdução da matriz institucional dos alemães ${ }^{11}$, e a produção de normas referentes aos princípios que estes sujeitos carregam. Seu período subseqüente - consolidação da Associação na favela - também comporta a produção de normas, que se gesta na organização da comissão de moradores para as lutas de âmbito da metrópole, e se generaliza no processo de conquista desta política pública específica, sendo estas entrecortadas pelas normas institucionais da ACMA.

A história da produção deste lugar na metrópole mostra a sobreposição e a articulação de estratégias que ganham concretude nas normas e vão transformando a prática sócio-espacial.

Esta política pública - "urbanização de favela - representa, simultaneamente, ganhos e perdas, possibilidades e limites, apropriação e dominação, tanto do ponto de vista dos moradores como das instituições (sejam elas próximas ou não da reprodução da vida dos habitantes). Tal política revela que o processo é contraditório, incorporando momentos de continuidade e ruptura de estratégias e de lógicas, que se transformam em contradições do espaço.

\footnotetext{
9 "A cotidianidade seria o principal produto da sociedade dita organizada, ou de consumo dirigido, assim como a sua moldura, a Modernidade" (Lefebvre, 1991, 82). A cotidianidade seria a vida cotidiana programada, induzida, por ideologias, a tendência à fragmentação da vida, pelo mergulho na racionalidade produtivista e do consumo. Suas implicações alcançam e privilegiam a reprodução da vida, reduzindo-a a miserabilidade do tempo escasso, a impossibilidade de realização do desejo e da apropriação do espaço. No plano da cidade representa o movimento de destruição dos referenciais, de efetivação do estranhamento do habitante frente a sua obra, a cidade. No plano da habitação, é a passagem do habitar, que se apóia nos desejos e referencias da vida para o habitat, carregado de normas de uma ordem distante, que aparece estranha ao morador da metrópole. Isto nos leva a considerar a cotidianidade como a linguagem do processo de alienação que o homem da sociedade urbana se encontra.

10 “O cotidiano, ele próprio, é uma mediação entre o econômico e o político, objetivação de estratégias do estado no sentido de uma gestão total da sociedade; lugar de realização da indústria cultural visando os modelos de consumo, no que se destaca o papel da mídia. Enfim, no cotidiano, entre o concebido e o vivido, travam-se as lutas pelo uso, sempre envolvendo as particularidades na direção e com o sentido de firmarem-se como diferença.” Seabra, O. A insurreição do uso, pp 77.

${ }^{11}$ A partir de concepções antroposóficas esses alemães estabelecem uma forma de trabalho na favela regido pela chamada auritmia, base da organização, que será tratada no percurso da pesquisa.
} 
Já a segunda ação a ser analisada, se refere à atividade teatral realizada internamente à ACMA por jovens da favela e de outras localidades da metrópole (próximas ou não da sede). Ela representa na pesquisa uma possibilidade de mediação para a compreensão da apropriação do espaço não articulada com a lógica do consumo.

$\mathrm{O}$ uso do espaço ${ }^{12}$, mediado pelo teatro, revela, numa perspectiva interna às relações tecidas entre os moradores e a ACMA, uma transgressão à degradação da vida na metrópole. Este uso reúne elementos próprios da arte fundada na reflexão sobre a realidade na qual estão imersos seus participantes. Trata-se de um espaço-tempo criado para a apropriação por meio do corpo e que transforma-se no espaço-tempo da reunião, do debate sobre as condições de vida dos jovens, de brincadeiras e no momento de conhecer o outro para a produção de um projeto coletivo.

Esta ação não está imune às normas da ACMA e no recuo à história desta atividade, tais normas aparecem mais claramente a partir dos conflitos entre os coordenadores do núcleo teatral e a diretoria, e atualmente fazendo-se perceber nas crises existente entre os jovens que realizam o trabalho e, novamente, a diretoria.

No plano da metrópole, esta ação possui um papel importante por despontar como "âncora” da centralidade desse núcleo. Neste uso específico da Associação Comunitária, o lugar se torna um centro de referência, que aos poucos vai dando visibilidade aos demais usos que se faz no espaço da favela. Quando membros da Associação e moradores da favela empreendem ações de cunho cultural e, apresentando-se em vários pontos da metrópole o trabalho criado, ou mesmo, em outros municípios e países as realizações do Centro Cultural (música, teatro e dança), a centralidade adquire visibilidade e se amplia.

Uma contradição, porém, se coloca, pois ao mesmo tempo em que as atividades culturais possibilitaram a visibilidade das demais atividades e reforçaram a ACMA como um centro de reunião; o teatro, uma das atividades de maior destaque, se articulava com vários grupos culturais da metrópole, inclusive, trazendo estes trabalhos para serem apresentados na favela por meio do uso do Centro Cultural, o que ocasionou uma extensão das tensões no confronto com o projeto antroposófico de arte adotado pela diretoria.

Tais tensões, pelo relatado em conversas com antigos membros, se construíam por meio dos diferentes projetos que os demais grupos traziam de suas regiões para a

\footnotetext{
12 "O conflito pelo uso do espaço estaria revelando a essência do processo social: a propriedade lutando contra a apropriação.”, Seabra. O, A insurreição do uso, pp. 79.
} 
ACMA. Isto é, as formas de compreensão de um mundo apresentadas pelos outros grupos através das peças e debates que ocorriam, muitas vezes não condiziam com as normas da própria instituição onde se realizavam os espetáculos. Aos poucos, pelos critérios da ACMA, foi cerceada esta dinâmica e a atividade cultural perdeu sua potência de mediação como possibilidade de apropriação do espaço. Contudo, ela ainda existe e torna-se uma ação potente de desvendamento das transgressões para a realização da vida na metrópole.

Essas duas atividades - “urbanização da favela” e grupo de teatro - nos abrem a perspectiva, em facetas diferentes, de tentar compor um entendimento sobre a tendência do empobrecimento da vida e as suas insurgências como um dos conteúdos da urbanização.

\section{O Movimento da Exposição}

O momento da exposição da pesquisa é o instante das escolhas, e ele não se confunde com a investigação, pois esta nos encaminha por várias direções, mesmo que estejamos com determinada problemática construída. Este momento trata-se, então, da reunião das opções para dar destaque a determinados aspectos que o pesquisador acreditou serem os mais plausíveis para a compreensão da problemática. É uma circunstância específica que demonstra uma oportunidade de diálogo entre o pesquisador e o público em geral, ao mesmo tempo, que apresenta o acúmulo de conhecimento. Acreditamos não ser algo fechado e absoluto, mas sim uma oportunidade de continuidade da construção do conhecimento, bem como, o de direcionamento às novas descobertas por meio dos diálogos suscitados por este raciocínio ora apresentado.

Nesta direção, a dissertação se compôs em três capítulos, cada qual com uma hipótese específica: As Continuidades e Rupturas na produção do Lugar, Da Periferização às Centralidades na Periferia e a Territorialização da Associação Comunitária Monte Azul, respectivamente.

O primeiro capítulo parte da potencialidade da apreensão da paisagem e da morfologia do lugar para o desvendamento dos conteúdos da urbanização da metrópole paulistana, traçando uma periodização calcada na metamorfose de ambas que irá expor as continuidades e rupturas da produção do lugar, como também, a das relações sociais tecidas no âmbito do lugar conforme o processo de sua produção. Também, situamos este lugar na totalidade da metrópole, ou seja, localizando-o no processo geral de 
produção da metrópole, já que a favela é produto da periferização advinda da industrialização.

O segundo se refere à produção do lugar enquanto uma centralidade na periferia, destacando o processo hegemônico de produção do espaço urbano, a transformação do espaço em mercadoria intercambiável, e as implicações deste processo para a reprodução da vida dos habitantes da metrópole. A centralidade aparece como produto desta lógica e, visando a sua manutenção é central o papel das instituições, que se territorializam pela periferia e exercem funções diferenciadas, como as organizações não governamentais, que atuam muitas vezes na introdução de normas para a constituição do cotidiano programado. Este movimento irá reiterar a manutenção da reprodução das relações de produção.

No último capítulo, traçamos a territorialização da Associação Comunitária Monte Azul, as ações de “urbanização da favela” e a prática do núcleo teatral. Tentamos explicitar com estes elementos, o projeto da Associação, a sua matriz discursiva e as implicações de suas ações em relação aos sujeitos presentes na favela, chegando até o momento da crise atual da instituição e dos próprios moradores. É neste capítulo que conseguimos destacar as transgressões dos sujeitos implicados na produção do lugar, por meio dos usos e das normas postas por esta instituição, denotando o empobrecimento da vida dos habitantes da metrópole pelas subordinações a que estão sujeitos. 


\section{Capítulo I}

\section{As Continuidades e Rupturas na Produção do Lugar}

"Em vez de cidades de luz arrojando-se aos céus, boa parte do mundo urbano do século XXI instala-se na miséria, cercada de poluição, excrementos e deterioração." Mike Davis ${ }^{1}$

A desigualdade é produto da produção do espaço, marca histórica da sociedade e do processo de urbanização. Como afirma Davis (2006), as promessas de um urbanismo de décadas atrás nos conduzia a pensar que o futuro da maioria das cidades seria de ferro e aço, porém, tal previsão não se concretizou. O que apenas se erigiu foram centralidades internas às metrópoles que se produziram nestes parâmetros construídos pelos urbanistas e arquitetos, que projetavam a nova cidade. Mas a avassaladora maioria da população se encontra sob as circunstâncias mais degradantes do habitat, morando em favelas ou nos bairros onde prevalecem os loteamentos clandestinos. Isto significa, atualmente, mais de um bilhão de habitantes residindo em favelas em todo o mundo e mais do que esta cifra morando em condições precárias.

A condição de degradação a qual nos referimos, é apreendida, inicialmente, por meio da paisagem da metrópole. Esta última torna-se ponto de partida para o desvendamento dos conteúdos sociais da produção do espaço, já que forma e conteúdo se relacionam dialeticamente. O mosaico das formas, das disposições das construções, dos equipamentos urbanos, da moradia, dos lugares de trabalho, pode nos remeter, aparentemente, a um “caos”. Esta aparência de “caos” é confundida com o desenho da desigualdade da produção do espaço urbano. A paisagem transforma-se, então, na expressão sintética deste processo e é expressão da forma de produção do espaço por meio do trabalho, mostrando-nos as possibilidades de uso de uma sociedade que está assentada sobre as relações de trocas mercantis.

A paisagem é simultaneamente concreta e abstrata, pois representa uma realidade não explicitada, ao mesmo tempo, que é a concretização da objetivação dos processos sociais. Ela nos permite o acesso ao conteúdo, pois a forma jamais está dissociada deste, e embora, o conteúdo possa estar escamoteado por uma forma, sempre esta forma dará as primeiras possibilidades de incursão ao encontro do fundamento do

\footnotetext{
${ }^{1}$ Davis, Mike, Planeta Favela, Boitempo, São Paulo, 2006, pp.29.
} 
processo. Por isso, a paisagem representa a reunião dos processos e relações sociais, desta simultaneidade de formas produzidas ao longo do tempo, inclusive impondo a necessidade da separação entre os sujeitos que produz um espaço urbano, colocando-nos diante do fato de que há usos diversos na metrópole.

Do mesmo modo que atentamos para o fato de que a paisagem está imbricada ao conteúdo, não podemos compreendê-la como uma forma estática, mas como algo que possui uma dinâmica, que está em constante mudança pelo próprio movimento das relações sociais, expressando, portanto, estratégias de classe, funções e hierarquias entre os lugares.

A paisagem da metrópole paulistana revela este “eterno” construir, desconstruir e reconstruir, que delineiam as intervenções das quais o espaço é objeto, seja para produzir ou reproduzir formas necessárias à reprodução ampliada do capital, seja para a população resistir às privações e expropriações presentes na vida cotidiana. Assim, a contradição entre a riqueza produzida socialmente e sua apropriação privada está estampada na paisagem urbana.

O olhar para a paisagem pressupõe estabelecer relações com as demais localidades e, dessa maneira, revela o sítio e a situação da metrópole, com suas particularidades e diferenciações. As localizações das favelas são exemplos de quão necessário é esta compreensão, pois no município de São Paulo ${ }^{2}$ a ocupação por favelas ocorre em locais diferentes das realizadas no Rio de Janeiro. Enquanto no primeiro as casas se constroem, predominantemente, nas beiras de córregos e áreas de proteção ambiental, no segundo, os habitantes enfrentam a declividade dos morros cariocas. Porém, o cerne da questão se encontra articulada ao processo geral de valorização do espaço.

São estas potencialidades apresentadas pela paisagem urbana que nos direcionou para a escolha desta como ponto de partida, pois ela se apresenta enquanto síntese do processo de urbanização contemporâneo, que carrega as formas de degradação da vida e também as transgressões necessárias à sobrevivência.

É esta aparência concreta da paisagem, síntese de múltiplas determinações, produzida pela justaposição dos planos da realidade, que buscamos como primeira

\footnotetext{
2 “Em São Paulo, elas estão localizadas, freqüentemente, em áreas de litígio, fundo de quintais, nas faixas marginais de vias e córregos, em terrenos ou construções temporariamente abandonados, áreas, enfim, que ainda não se destinaram para um uso coletivo ou não adquiriram um valor suficientemente rentável para serem comercializadas”, Kowarick, L., A Espoliação Urbana, Paz e Terra, São Paulo,1993, pp. 90.
} 
aproximação. A partir desta forma genérica de manifestação, podemos esmiuçar os processos intrínsecos as práticas do movimento da urbanização contemporânea.

Entretanto, o ato de desvendar os componentes da paisagem pressupõe a construção de uma problemática específica, que revele alguns dos conteúdos do complexo processo da urbanização enquanto processo social, e para tal nos exige também a escolha de um lugar, já que a metrópole não pode ser apreendida em seu todo.

O horizonte aberto, enquanto recurso de método, é o da compreensão da produção do lugar, sendo este apreendido tanto do ponto de vista da escala e localização, como de produto das relações sociais mais imediatas, evidenciando contradições da reprodução da sociedade. É por excelência o nível do uso, da apropriação, que está permeado pelas determinações de uma ordem distante que insiste em ordenar o espaço-tempo dos habitantes. É nele, o lugar, em que conseguimos ler as transgressões e resistências pelo fato deste ser o nível de realização da vida que, por sua vez, reclama a necessidade da transgressão para a sobrevivência.

A produção do lugar aponta, então, a articulação das relações mais próximas, aquelas em que ainda há a predominância da qualidade e que ainda não foi diluída por uma abstração advinda da quantificação do espaço-tempo necessário à reprodução capitalista. O Lugar é, ao mesmo tempo, objeto privilegiado de uma regulamentação bem como de constantes transgressões. Ele não deve ser visto somente, como os geógrafos de base fenomenológica concebem, como um conjunto (ou centro) de significados sobre os quais prevalece a percepção do indivíduo ${ }^{3}$. Compreender a produção do lugar, nos remete aos espaços e tempos construídos socialmente, bem como, aos conflitos entre os sujeitos sociais, abrindo-nos ao entendimento das contradições da dinâmica da tendência à lógica capitalista e mercantil na qual estamos inseridos. Neste processo de urbanização, que traz uma enorme produção material, produz-se igualmente novos valores, além de códigos morais, políticos e éticos renovados. Porém, isto ocorre sem conseguir excluir a identidade concreta que se constrói através da apropriação dos lugares por meio dos usos, no qual o homem se reconhece, mesmo que esta apropriação se realize residual e precariamente. É neste nível - o do lugar - que reside a prática sócio-espacial, motor da produção do próprio lugar, que está alicerçada nos usos, nas ações dos habitantes da metrópole. Esta prática contém a maneira como se produziu (e se produz) os sujeitos sociais neste período, as

\footnotetext{
${ }^{3}$ Estebanez, Jose, Tendências y problemáticas actual de la Geografia, Editora Cicel, s/data.
} 
formas de apreensão de sua relação com a cidade e o movimento constante de transformação das relações pelos conflitos com os quais o habitante se depara diariamente.

Portanto, compreender a produção do lugar e a prática sócio-espacial é um desafio. Para Santos (1994), a grande tarefa dos geógrafos é apontar as possibilidades existentes de transformação da sociedade no lugar, questionando o projeto dos atores hegemônicos, porque. “... o Lugar - não importa sua dimensão - é, espontaneamente, a sede da resistência, ás vezes involuntária, da sociedade civil...” ${ }^{4}$ Uma vez que o lugar é onde se lê concretamente as contradições, e sendo ele o nível privilegiado do conflito, estarão presentes também a degradação e a resistência, como constituintes de um mesmo processo.

Nas ações de uma ordem distante, que tende a instaurar o controle sobre os lugares da metrópole através de normas e funções, formam-se hierarquias entre estes, erigindo centralidades específicas e funcionalizadas. Há lugares na metrópole profundamente sintonizados com as redes mais avançadas de informação, realizando plenamente as funções da reprodução ampliada, e há ainda, outros que não vivem o brilho das luzes da modernidade, mas se inserem precariamente ao processo mundial. Na metrópole de São Paulo nos deparamos com a concentração dos prédios modernos com todo o aparato necessário a seu funcionamento, na “famosa” Avenida Luís Carlos Berrini, e em contrapartida, observamos a grande massa periférica onde parte da população ainda não é atendida pelo abastecimento de água e esgoto. A produção destes espaços se realiza simultaneamente, implicando-se, isto é, a concentração de riquezas produz contraditoriamente, a segregação.

Este objeto - o lugar - que é um recorte mental, mas que se justifica por bases reais, nos permite verticalizar alguns dos conteúdos do processo de urbanização, que não são possíveis de serem apreendidos na análise da metrópole em seu todo. Tê-lo como nível de análise nos concede a oportunidade de compreender o significado do espaço hoje e sua produção, quer dizer, compreender como o espaço urbano é produzido, como é apreendido enquanto condição e meio de realização tanto do processo hegemônico da acumulação capitalista, como do ponto de vista da população que sofre as mazelas do empobrecimento da vida regida pela lógica da troca mercantil.

\footnotetext{
${ }^{4}$ Santos, Milton, A natureza do espaço, Edusp, São Paulo, 1996, pp. 259.
} 
Portanto, descrever as formas, as estruturas e as funções presentes naquele lugar da metrópole, nos traçados das suas ruas e vielas, das casas e prédios, na construção do espaço público, bem como, o que existe no entorno em que este se insere, significa situar os processos circunscritos na produção do lugar no âmbito da metrópole enquanto uma produção social, revelando uma morfologia social, igualmente tendente a fragmentação, hierarquização e funcionalização. Para Carlos (1996)

“A produção espacial realiza-se no plano do cotidiano e aparece nas formas de apropriação, utilização e ocupação de um determinado lugar, num momento específico, e revela-se pelo uso como produto da divisão social e técnica do trabalho que produz uma morfologia espacial fragmentada e hierarquizada." 5

O destrinchar da produção do lugar inicia-se pela análise da paisagem, porém, a sua materialidade se revela na morfologia espacial, materialização dos processos postos à compreensão.

Assim, segundo Carlos (2001) “... a morfologia urbana não revela a gênese do espaço, mas aparece como caminho para a análise do modo como o passado e presente se fundem em determinado momento, revelando as possibilidades e os limites do uso do espaço pelo habitante" 6

\section{A Morfologia da Favela \\ Monte Azul}

O espaço de uso construído na favela Monte Azul, os prédios existentes, a circulação de pessoas moradoras e não moradoras, denotam a produção de um lugar diferenciado na periferia de São Paulo, e peculiaridades nas relações entre os sujeitos implicados nesta produção revelam

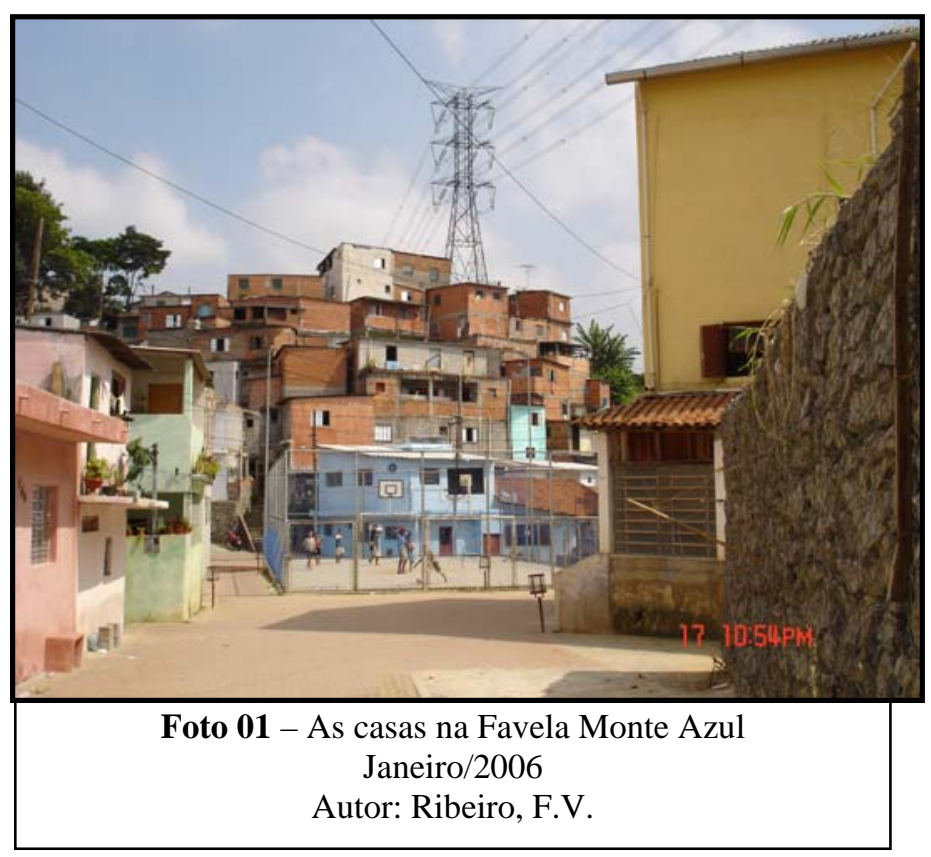

\footnotetext{
${ }^{5}$ Carlos, A. F. A., O lugar no/do mundo, Hucitec, São Paulo, 1996,pp 26.

${ }^{6}$ Carlos, A. F. A, Espaço-Tempo na Metrópole, Contexto, São Paulo, 2001, pp.46
} 
que sua morfologia é bastante singular. Qualquer pesquisador, turista ou pessoa que não resida nela, ficam impressionados com a magnitude das atividades ali concentradas.

Desde sua formação, em 1965, até hoje, sua morfologia foi radicalmente modificada, metamorfoseando os usos que os sujeitos fazem da favela e transformando a relação espaço-tempo. Podemos considerá-la, do ponto de vista das melhorias infraestruturais, como um modelo de projeto de “urbanização de favelas”, pela conquista de um amplo espaço de uso ${ }^{7}$ voltado predominantemente para o lazer e utilização dos serviços existentes.

Articulando a favela e seu entorno, atualmente ela pode ser considerada bem localizada, pois próximo dela concentram-se uma série de equipamentos urbanos que auxiliam na integração dos moradores com o restante da metrópole. Estes equipamentos urbanos são compostos por um terminal de ônibus, metrô, hipermercados, além de escritórios e prédios residenciais, que podem ser traduzidos como oportunidades de emprego para os moradores.

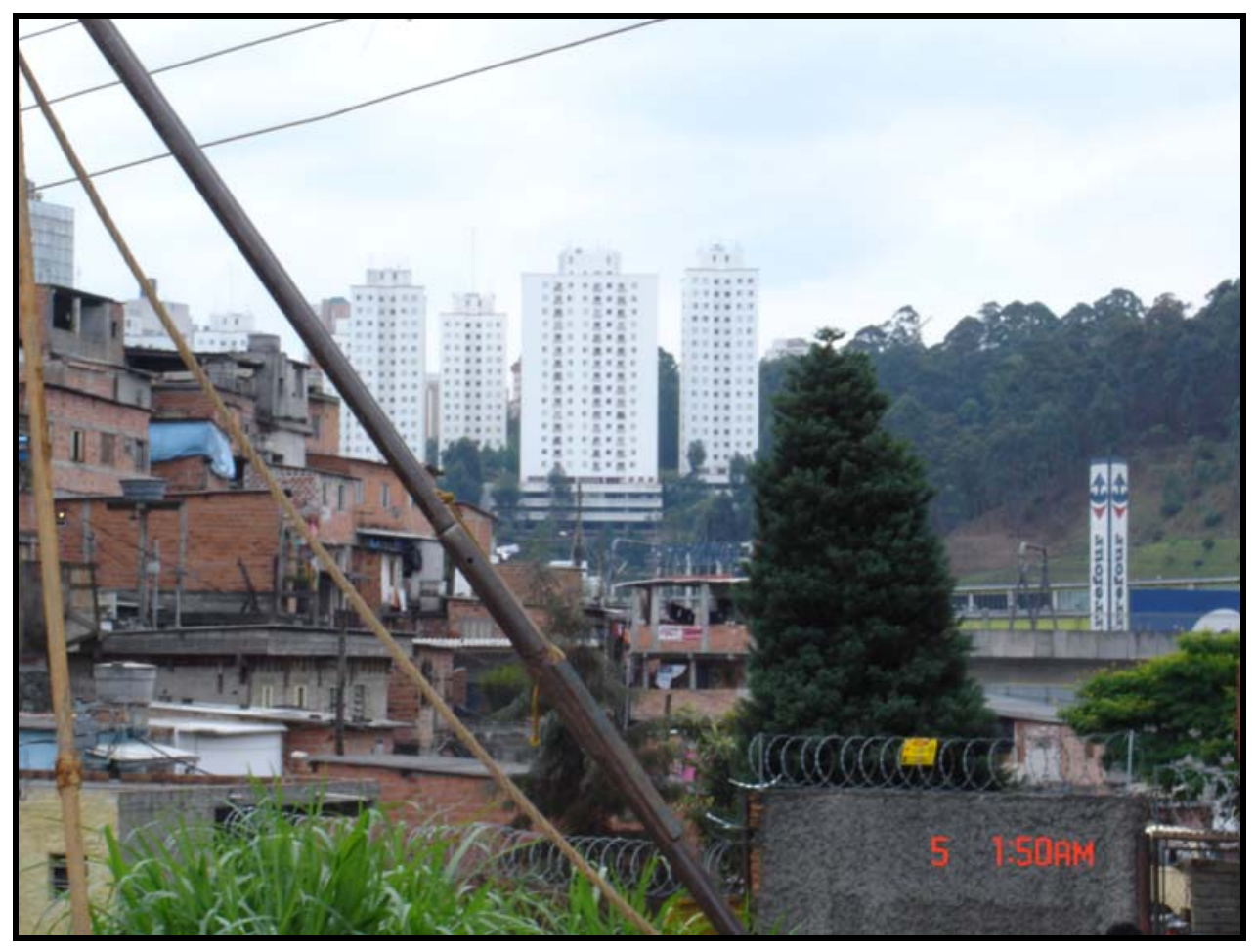

Foto 02 - No quadro há parte da Favela, ao centro um conjunto de prédios de classe média alta e a direita a torre do Hipermercado Carrefour e passagem do metrô. Fonte: Ribeiro, F. V., Out/2006

\footnotetext{
${ }^{7}$ Ao utilizar o adjetivo uso ao espaço queremos contribuir para a compreensão de que tal espaço possui características que revelam um processo de apropriação pelos moradores. Isto não significa que ela não esteja penetrada por formas de dominação de um sujeito que se territorializa no perímetro, e que insiste na normatização do espaço-tempo daqueles que ali residem. A dominação e apropriação do espaço é uma contradição de um mesmo processo, aquele da tendência da sobreposição do valor-de-troca sobre o valorde-uso na produção do espaço urbano.
} 
A favela encontra-se na porção sul do município de São Paulo, na Subprefeitura de M’Boi Mirim (Mapa 1- Localização da Favela Monte Azul), sua extensão abrange, segundo o último zoneamento do município, uma área de uso misto e outra industrial. O perímetro atual se configura como zona especial de interesse social (ZEIS) e possui desde 1993, o título de permissão de uso (regularização fundiária), representando conquistas históricas dos movimentos sociais que lutam pelo acesso à terra urbana.

Diante desta morfologia diferenciada o que podemos constatar? Um alto grau de resistência deste lugar diante das formas de expropriação e espoliação urbana? Chegamos aqui em um ponto em que emerge uma questão que pretende ser esmiuçada no decorrer da pesquisa, e que tem a ver com as possibilidades de transgressões e resistências à degradação da vida, pois suas conquistas provieram de uma relação específica dos sujeitos sociais ali implicados, distanciando-se das clássicas formas de lutas dos movimentos sociais urbanos na metrópole de São Paulo. A produção desta favela não representou um distanciamento das ações coletivas existentes na metrópole. Houve um diálogo e inserção nas lutas, mas com uma conotação diferenciada dos movimentos sociais existentes na época, por conter dentro dela - a favela - projetos distintos dos sujeitos que agiam sobre aquele lugar. Na medida em que a morfologia do lugar se transformava, as relações sociais que a produziam também iam igualmente se metamorfoseando, ganhando novos conteúdos internos, delineando uma morfologia social. Por isso, trata-se de uma prática sócio-espacial de vários sujeitos sociais implicados que produz o lugar.

Por compreender que as transformações morfológicas do lugar estão profundamente articuladas e imbricadas com as modificações das relações existentes internamente a ele ao longo de sua história, entendemos que a prática sócio-espacial ganha novos conteúdos emergentes de rupturas, porém, comporta continuidades. Desse modo, em uma tentativa de capturar estas rupturas, propomos uma periodização que tenta levar em consideração as metamorfoses da relação espaço-tempo dos sujeitos e as mudanças morfológicas, expondo à analise as transformações de qualidade das relações na produção do lugar. Isto nos coloca diante do fato de que há temporalidades que se justapõem, construindo um movimento interno do lugar, que se encontra articulado e não prescinde do movimento geral da metrópole.

Esta periodização também está calcada no significado de produção e reprodução, já que este processo revela o modo de dominação e apropriação dos objetos pelo 
homem, como ele o transforma e quais as finalidades de uso. Na medida em que realiza esta criação e ao se relacionar com ela, o homem tece a própria humanidade. A produção possui um sentido amplo, um significado de produção de objetos e do homem e sua humanidade. Esta produção está vinculada ao modo como o homem reproduz sua vida, em um acúmulo de contradições e produção de outras.

O momento de reprodução, visto pela ótica da periodização, primeiramente, pode se qualificar pelo ato da repetição das práticas necessárias à finalidade de reprodução dos sujeitos que realizam suas estratégias de sobrevivência. Esta reprodução, que já contêm contradições, as acumula e produz novas. As estratégias dos sujeitos se realizam levando a cabo o conflito entre apropriação e dominação do espaço e, tornando-se ainda mais repressivas ao outro, ao passo que os conflitos se reatualizam com novos formatos e dinâmicas, mas construídos sob o mesmo fundamento, que em tese, encaminha-se para uma ruptura radical. Isto não significa que em seu período de reprodução não haja produção de relações.

Por isso, compreendemos que,

“a noção de produção se vincula a produção do homem, às condições de vida da sociedade em sua multiplicidade de aspectos, e como é por ela determinado. Aponta, por sua vez, para a reprodução, e evidencia a perspectiva e compreensão de uma totalidade que não se restringe apenas ao plano do econômico, abrindo-se para o entendimento da sociedade em seu movimento mais amplo o que pressupõe uma totalidade."8 (Carlos; 2000;13)

A periodização aqui proposta pode sugerir uma rigidez e até modelação de um processo social. Porém, a tentativa estabelecida é posta enquanto um recurso do método de exposição para situar as mudanças e rupturas. Estas mudanças, no entanto, não se realizam em um tempo marcado, mas sim, o caráter da ruptura se assenta na sobreposição de espaços-tempos, levando a tendência do predomínio de um deles. Os momentos de produção e reprodução, longe de aparecerem desarticulados, devem ser apreendidos em seu imbricamento, e conforme o momento em que as relações sociais estão sendo analisadas, é posto em relevo um dos aspectos.

Assim, compreendemos que a Favela Monte Azul se produziu em três momentos: formação, produção e reprodução. A formação se articula ao momento

\footnotetext{
${ }^{8}$ Carlos, Espaço-Tempo na Metrópole, Contexto, São Paulo, 2001, pp 13
} 
inicial de ocupação do terreno, predominando relações de um sujeito específico, os moradores. O momento da produção se refere ao encontro dos residentes com os sujeitos pertencentes ao grupo que constituirá a Associação Comunitária Monte Azul de base antroposófica. Este encontro mudará qualitativamente a produção do lugar, configurando-se enquanto uma ruptura. O último momento que destacamos é o da reprodução do lugar, no qual há um acúmulo de conflitos, revelando contradições que se produziram no período da produção da favela e que atualmente, ganham outra magnitude e produzem novos conflitos pela modificação das relações mais amplas da metrópole. A sua marca é uma profunda crise de reprodução, tanto da ACMA como dos moradores. Neste período se efetiva a territorialização da ACMA e a produção de uma morfologia diferenciada das favelas da metrópole, em decorrência de uma intervenção a “urbanização de favela”.

\section{Os Momentos de Produção do Lugar}

\section{A - A Formação da Favela Monte Azul}

Uma favela, em seu período de formação, é a expressão da espoliação do habitante, vista por meio da crise de moradia tão bem delineada na morfologia desigual da metrópole em seu período industrial.

A Favela Monte Azul, iniciada em 1965 por ocupações espontâneas, é fruto das relações de trabalho preconizadas no período da São Paulo industrial. Em finais da década de 50, parte das indústrias se transfere para a região sul do município de São Paulo, devido, principalmente, aos baixos custos dos terrenos ao longo das margens do Rio Pinheiros. Como conseqüência disso, parte dos trabalhadores se desloca para garantir ou conseguir uma oportunidade de trabalho na metrópole. A crescente mobilidade do trabalho produzida pela necessidade do processo de industrialização, faz com que contingentes de migrantes se dirijam à metrópole, submetendo-se aos baixos salários oferecidos pelas indústrias. Entretanto, sua inserção no mercado de trabalho, principalmente, no industrial, não significou a possibilidade de entrada ao mercado formal de terras, ou a garantia de conseguir pagar o aluguel de um imóvel(Kowarick: 1994, Maricato; 1982, Bonduki; 1982, Rodrigues; 1988, Sader; 1988). Pelo contrário, na associação de dois processos, decréscimo dos salários e valorização da terra, os trabalhadores urbanos se vêem sem condições de arcar com os custos de moradia, 
restando-lhes somente a opção de ocupar terras, pois seu direito à casa, se submete às leis mercantis,

"Em todas as formas de apropriar-se do espaço urbano está implícita, na cidade capitalista, o pagamento pelo uso e pela propriedade da terra e da moradia. Na apropriação da cidade capitalista está embutido o pagamento." 9

A metrópole de São Paulo inicia o aumento da produção de habitações precárias, destacadamente as favelas, a partir da década de 40 do século XX. Cabe ressaltar que, ainda no período de constituição da favela Monte Azul, na década de 60, São Paulo era uma metrópole considerada com um baixo número de favelados em comparação com outras metrópoles da América Latina, como por exemplo, a Cidade do México, Santiago ou Lima. Segundo Kowarick (1993)

“Comparada com outras metrópoles latino-americanas, a população favelada de São Paulo é pouco numerosa. Na Cidade do México, por exemplo, 45\% dos habitantes moram em favelas ou em aglomerações de características semelhantes. Em Caracas representam mais de 1/3 dos moradores da cidade. Santiago tem $1 / 4$ da população vivendo em callampas e em Lima, metade dos habitantes mora nas barriadas" 10 .

No caso da favela Monte Azul, como uma das favelas que surge neste período, se compôs por migrantes vindos de Minas Gerais (25\%) e Bahia (21\%) predominantemente, além de outros estados nordestinos (Merege, 2001).

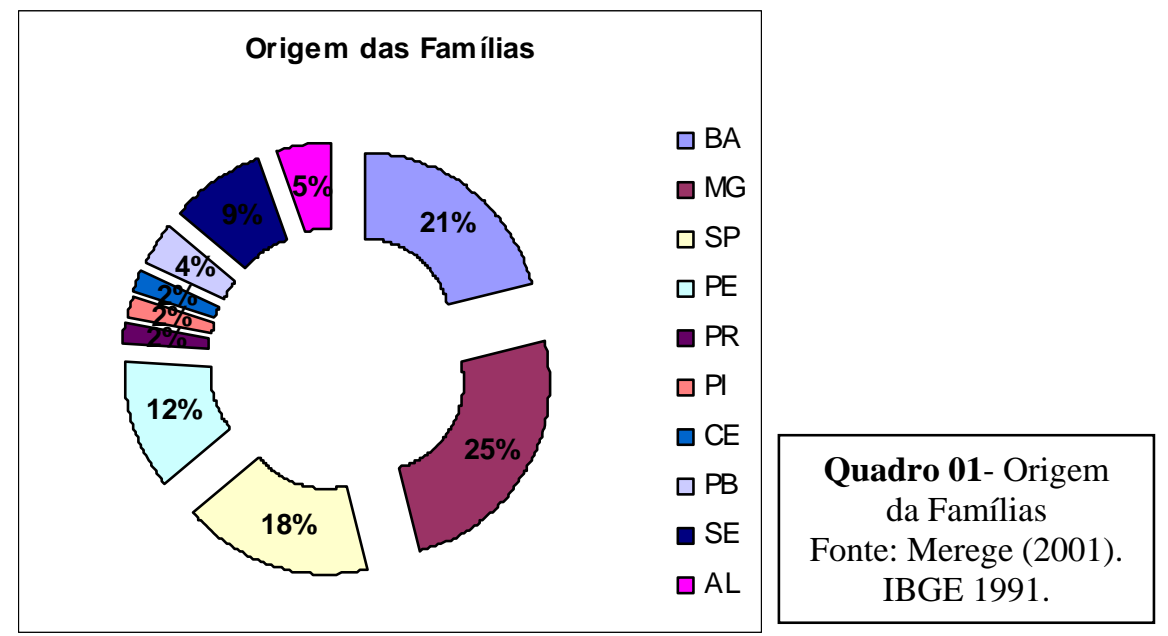

\footnotetext{
${ }^{9}$ Rodrigues, A. M. , Na procura do lugar o encontro da identidade: Um estudo do processo de ocupação coletiva de terra para moradia - Osasco, tese de doutorado, Faculdade de Filosofia, Letras e Ciências Humanas - Departamento de Geografia - USP, São Paulo, 1988.

${ }^{10}$ Kowarick, Lucio, A favela como fórmula da sobrevivência, In: A Espoliação Urbana, Paz e Terra, São Paulo, 1993, pp. 79. Este texto foi escrito na década de 70.
} 
As favelas tornaram-se a manifestação da desigualdade e exploração do trabalhador da indústria e da precarização dos trabalhos realizados na metrópole, ou ainda, uma das faces do desemprego, como explicita Kowarick(1993),

“Na realidade, a crescente favelização que se operou no município de São Paulo nada mais é do que um dos resultados do acirramento da exploração do trabalho que só pode levar a um crescente grau de espoliação nos níveis de consumo do habitante urbano. Num quadro em que os salários tornamse cada vez mais espremidos para cobrir os gastos básicos - entre os quais os referentes à moradia - a favela pode aparecer como a única alternativa para aqueles que querem permanecer na cidade. Quer porque os aluguéis tornam-se incompatíveis em face do minguado orçamento de consumo de muitos trabalhadores, quer porque a compra de terreno e a construção da casa própria sejam onerosos e impliquem também regularidade nos ganhos da família que ingressou nesse longo e tortuoso processo de aquisição, qualquer crise que ocorra pode significar a perda da possibilidade de canalizar recursos nos gastos com habitação. Essa crise - doença, acidente de trabalho ou desemprego -, freqüente no cotidiano da mão-de-obra que se desgasta no processo produtivo, constitui uma das fontes de favelização, pois muitas vezes representa, para as famílias de poucos salários mínimos, a impossibilidade de continuar pagando as dívidas ou aluguéis imperantes no mercado imobiliário."95

Essas razões do processo de favelização puderam ser apreendidas pelas entrevistas de dois moradores da Monte Azul, resgatando estas causas mencionadas acima. O primeiro morador entrevistado - D. Lourdes - se destaca por ser o primeiro que ocupou o terreno da futura favela e, o segundo - Seu Tião, que construiu seu barraco em meados da década de 70, nos fornece os elementos das perdas que a mudança para a favela o fez enfrentar. Dona Lourdes, nos contou seu percurso antes de chegar ao terreno:

“Eu pagava um terreno aqui na Monte Azul [bairro] mesmo, lá em cima [loteamentos irregulares]. Hoje tem uma casa muito bonita em cima. Eu pagava esse terreno. (...) Tava pagando o terreno pra mim [depois] comprar o material. Depois eu perdi o terreno e ai fui me bater atrás pra onde eu ia morar. Não podia pagar aluguel. Meu marido tava internado. Era só [ele] quem trabalhava, e eu fiquei, procurei terreno até lá pra Santo 
Antonio tudo eu procurei terreno da Prefeitura pra eu morar. (...)Ai eu fui no corretor e o corretor não queria por ninguém aqui [terreno do loteamento transformado em público] que enquanto não terminasse de vender tudo, né? (...) Ai foi onde eu tirei meu barraco de lá, só o barraquinho mesmo, tirei e deixei o terreno e falei, o terreno ta entregue e eu vou cuidar da minha vida."11

D. Lourdes, por não conseguir pagar o terreno ou um aluguel, entrega sua casa para a companhia de quem comprou o terreno, e sai a procura de um lugar público para levantar seu barraco. Com cinco filhos e o marido internado devido a um acidente de trabalho, ergue seu barraco no extremo sul da área que seria, futuramente, a favela Monte Azul. Este drama por que passou D. Lourdes em meados da década de 60, aparece como exemplo de um processo de urbanização visto enquanto negócio, isto é, a sobreposição do valor-de-troca sobre o valor-de-uso. Esta é a história que se repete nas vidas daqueles que aos poucos vão levantando seus barracos neste terreno. O conjunto dessas histórias expõe as bases do processo de favelização.

Outro elemento importante deste relato é a noção dada dos mecanismos de funcionamento da propriedade privada do solo, com as diferenças entre os terrenos que estão inseridos num circuito mercantil - terrenos privados - e aqueles que possuem um regime diferenciado de propriedade - terrenos públicos. Assim, começa a história de contingentes da população à procura de suas morada, mostrando como esta população, inserida precariamente na cidade produzida sob a lógica do valor-de-troca, realiza as possibilidades do morar, igualmente precário.

No segundo depoimento, Seu Tião, mais explicitamente, mostra a impossibilidade do pagamento do aluguel, bem como, a precarização da vida daqueles que tinham acesso a determinados bens no período;

“ $O$ dono ia vender a casa e eu não podia comprar, ai procurei aluguel por todo o canto, só alugava para quem não tinha filho. Ai só sobrou comprar um barraco na favela. E onde nós compramos um barraco [Favela Monte Azul] se chegasse três pessoas em casa, tinha que conversar lá fora porque era muito apertadinho (...)

Eu senti muita diferença, porque quando eu saí do aluguel, eu tinha geladeira, tinha televisão, tinha muitas coisas, e quando eu me mudei pra

\footnotetext{
$\overline{{ }^{11} \text { Depoimento dado em abril de } 2006 .}$
} 
favela, eu não podia usar nada disso, por causa [que] a energia não dava, não podia usar uma televisão e nem uma geladeira. Nessa época eu trabalhava na metalúrgica." 12

Ambos os fragmentos das entrevistas sobre a vida dos moradores e colhidos na pesquisa realizada com estes, ilustram os mecanismos do processo de favelização. Um nos aponta a associação entre os salários e o preço da terra, o outro vislumbra a dimensão da depreciação salarial e as impossibilidades de usufruir conquistas pretéritas, como o uso de bens, ou a casa para o acolhimento dos amigos.

Outro fator de relevância é o percurso da procura do terreno no qual será assentada a casa. Tal procura é referendada pela propriedade da terra, pois D. Lourdes buscará o terreno da Prefeitura, já que nele há uma "garantia relativa" de uma permanência maior, denotando as diferenças do regime de propriedade e as possibilidades de transgressão para a realização da reprodução da vida.

Quanto a questão da propriedade, a favela em seu período de formação remonta aos clássicos processos de ocupação dos loteamentos privados. Estes loteamentos, por lei, devem reservar uma porção de seus terrenos para a instalação dos equipamentos públicos, de infra-estrutura e de áreas verdes, transformando-os em propriedade estatal. As porções destinadas a estes fins mencionados, que se transformavam em terreno público, geralmente, são as piores áreas em termos de valorização para a implantação de lotes, ou seja, margens de córregos, alta declividades, etc.

No caso da formação da favela Monte Azul não foi diferente dos demais processos ocorridos na cidade de São Paulo. Ela se constituiu sobre a área pública de dois loteamentos implantados na época, e o início de sua formação foi em meados da década de 60, quando, segundo entrevista com D. Lourdes, nem todos os lotes particulares haviam sido vendidos.

No período, os loteamentos onde a favela se implantou, não haviam sido aprovados pela prefeitura, mas estavam sendo comercializados (ver figura $\mathrm{n}^{\circ} 01$ ). Hoje, após quase cinco décadas, somente um está regularizado enquanto o outro teve o processo de regularização extraviado na Prefeitura ${ }^{13}$.

Para contextualizar a situação fundiária atual, situaremos a condição de ambos os loteamentos no período de formação do lugar para verificar onde estão localizadas as

\footnotetext{
${ }^{12}$ Depoimento de Seu Tião em setembro de 2005.

${ }^{13}$ Este dado foi encontrado em pesquisa realizada na Secretaria Municipal de Planejamento de São Paulo no ano de 2006.
} 
moradias da favela e os prédios da ACMA, fator importante para compreender a territorialização da Associação. Este recuo ao período de formação nos permite entender o fundamento das formas de poder dadas atualmente pela situação da propriedade da terra existente.

O loteamento situado a leste da favela, abrangendo a R. Vitalina Grassman, teve seu pedido de inscrição feito no ano de 1967 e, somente no ano de 1980 o poder público iria aprovar a planta, embora a comercialização dos terrenos já havia sido realizada na própria década de 60. A situação jurídica deste loteamento é de suma importância para o trabalho, porque a maioria dos prédios pertencentes à Associação Comunitária Monte Azul se assenta sobre ele, o que os caracteriza como de propriedade particular. Uma vez que os prédios são particulares, a Associação possui a legitimidade de atuação sobre eles, sem necessariamente se articular com a população local.

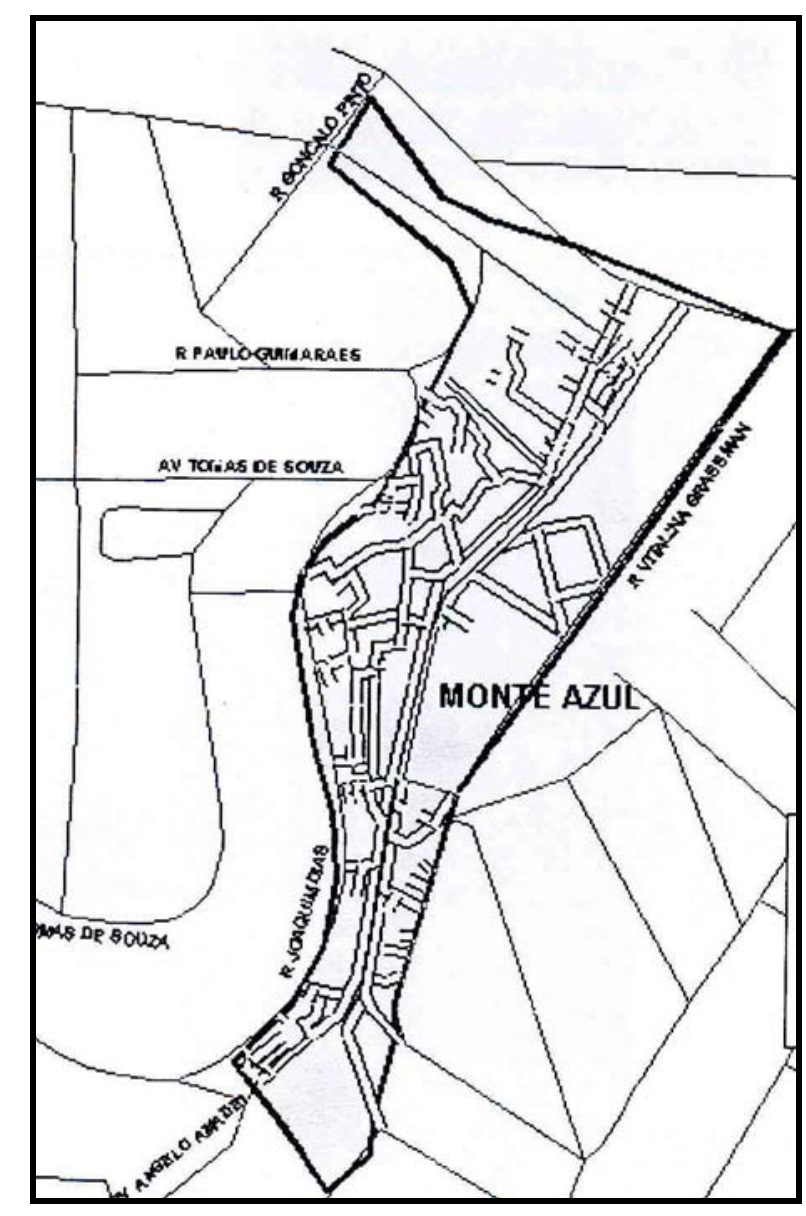

Figura 01 - Favela Monte Azul com sua localização e vielas.

Fonte: Merege, L. C., Relatórios de Pesquisa.

Elaboração:Silva, C., Instituto Lidas. Reelaboração: Ribeiro, F. V.

O segundo loteamento, que abrange um total de 610 lotes, localiza-se ao longo da Avenida Tomas de Sousa e R. Joaquim Dias (ver figura $\mathrm{n}^{\circ}$ 01), e até o momento, se apresenta em situação de irregularidade. Na pesquisa de campo, constatamos o extravio 
do processo no ano de 1990, sendo que a entrada do pedido de aprovação data do ano de 1961.

Conforme a prática comum nos parcelamentos de solo, as áreas destinadas ao poder público foram aquelas que reuniam as piores condições, portanto, possuíam menor interesse junto ao mercado imobiliário. Será nestas duas áreas destes loteamentos que a Favela Monte Azul virá a se formar.

Estas áreas destinadas ao poder público possuem outras características que promoviam a desvalorização e, que até hoje acarretam problemas para qualquer intervenção a ser realizada. Há uma faixa non aedificante da Eletropaulo, faixa de segurança das torres de fios de alta tensão, que quando construídas, décadas atrás, não previam a expansão do tecido urbano, e hoje, cortam a favela. Somado a isso, há a passagem do oleoduto da Petrobrás, apontando o fato de o subsolo ser controlado e impedindo o uso na superfície. 
Capítulo I

As Continuidades e Rupturas na Produção do Lugar

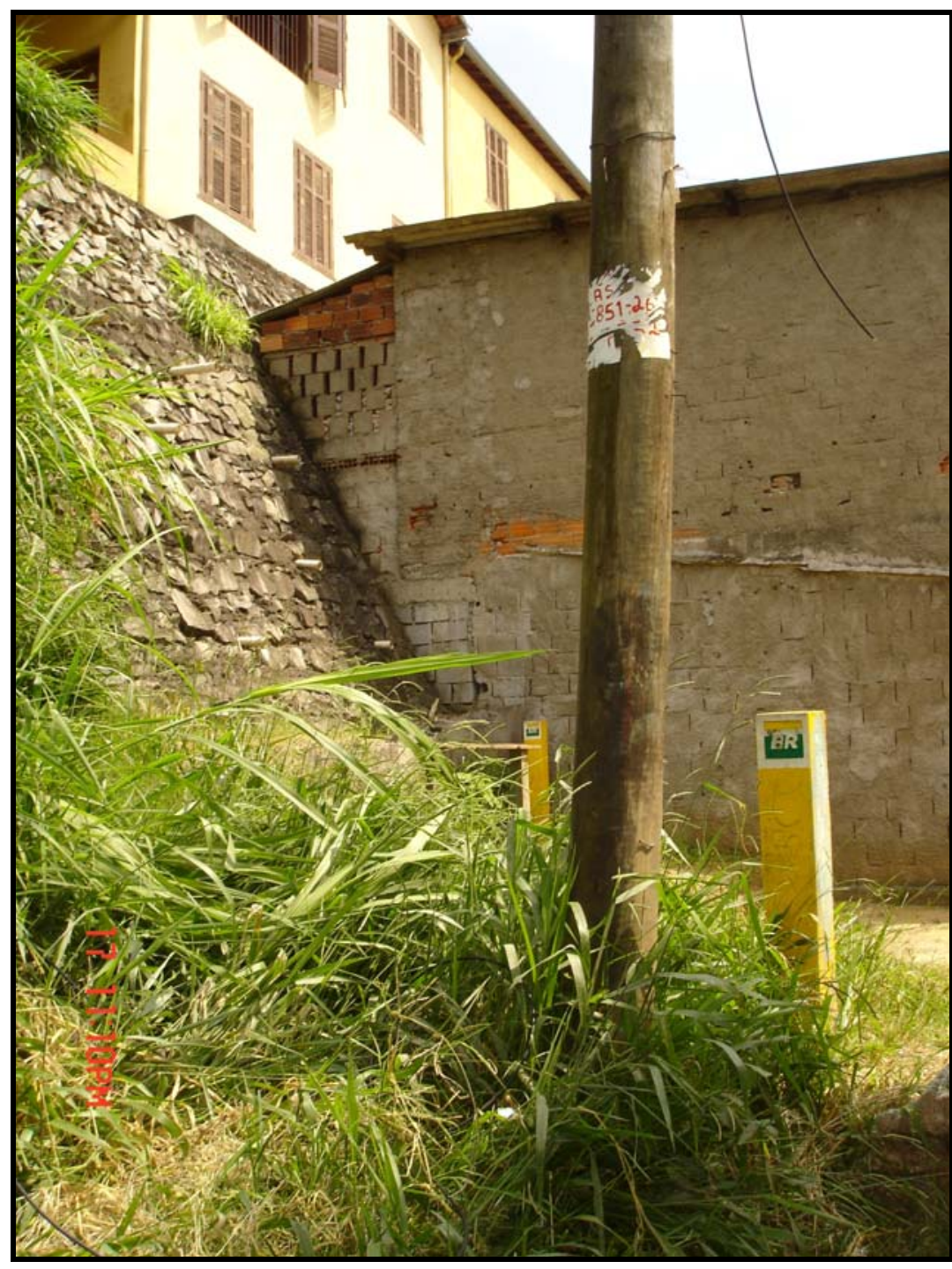

Foto 03 - Marcação da passagem do oleoduto existente sob a Favela. Autor: Ribeiro, F. V. Jan/2006

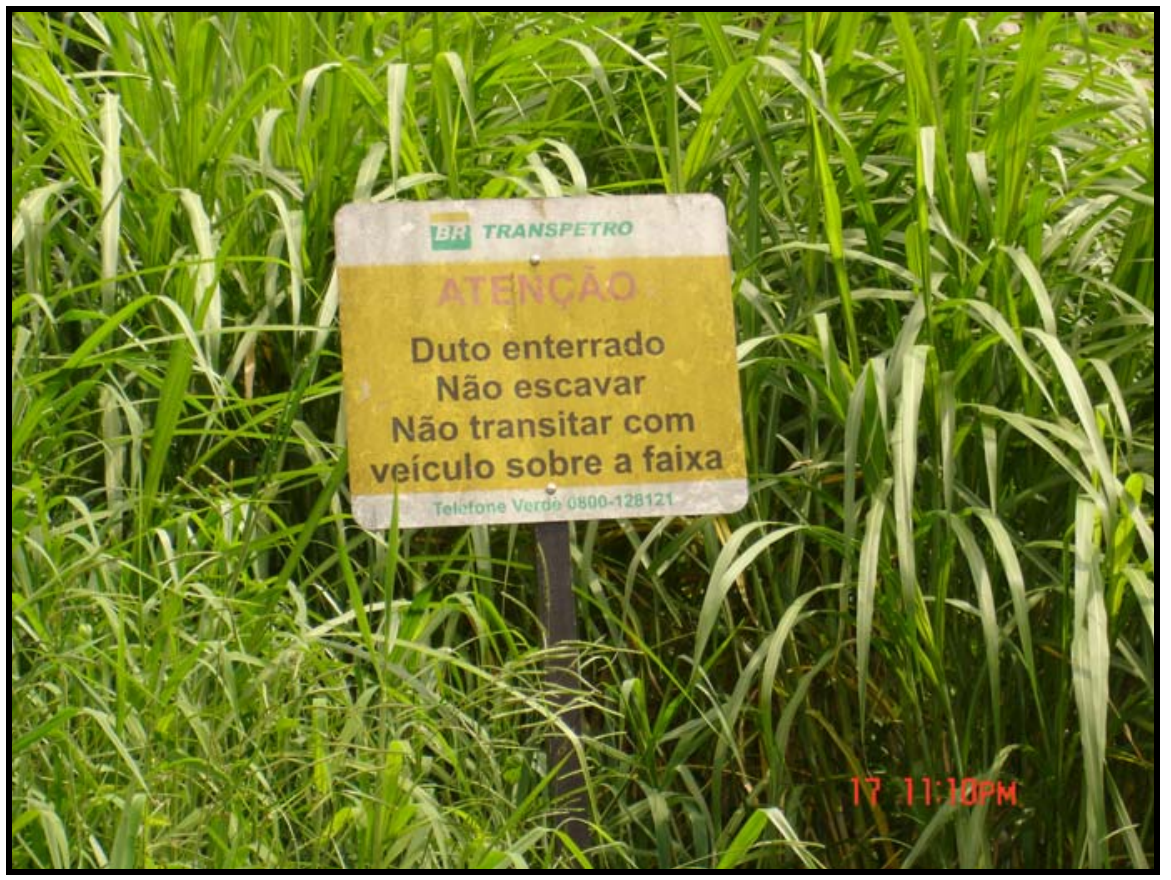

Foto 04 - Aviso da Petrobrás sobre o oleoduto existente. Autor: Ribeiro, F.V. Jan/2006 
A justaposição dos proprietários do terreno redundou em uma redução dos usos daquele lugar, mas, permitiu o acesso à terra aos moradores espoliados da cidade. Em relação a esta redução, vista principalmente com o processo de “urbanização da favela”, temos o impedimento de usar o terreno para necessidades de ampliação do espaço de uso, restando somente a alternativa de implantação de uma horta comunitária sobre ele e, que até o início de 2007 não havia sido organizada. O que há sobre esta faixa é uma ponte de acesso a outra margem do córrego e alguns interditos do período de reprodução que provêm do regime de propriedade, elementos constituídos através da ocupação dos moradores na formação da favela, como por exemplo, a não possibilidade de canalização do córrego nesta parte do terreno.

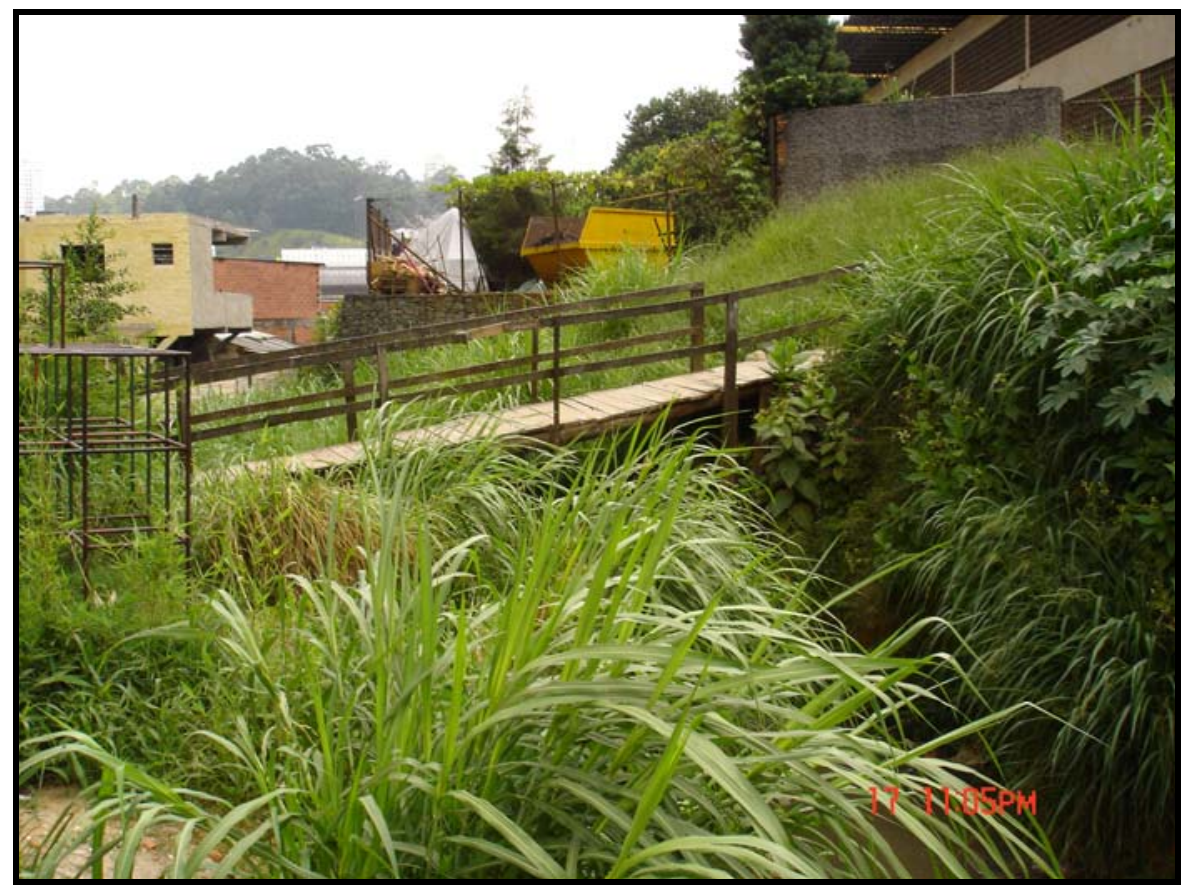

Foto 05 - Ponte sobre o trecho do córrego que não pode ser canalizado. Autor: Ribeiro, F.V. Jan/2006

Por fim, o período de formação da favela Monte Azul mostra o regime de propriedade na qual ela se assentou e as conseqüências deste processo até o seu período de reprodução. Isto significa que há uma continuidade dada pelos elementos de regimento das terras na cidade. 


\section{B - O Momento de Produção da Favela Monte Azul: A Chegada dos Antroposóficos}

Em um segundo momento, ocorre a produção da favela a partir do adensamento populacional ocorrido na década de 80, e da inserção deste lugar nos referenciais de um projeto de sujeitos não residentes na favela e que tinham como base a antroposofia ${ }^{14}$. A ação destes novos sujeitos, que se envolvem e se articulam com a população local, é a inflexão qualitativa de produção deste lugar. É o marco das mudanças nas relações e na morfologia da favela, além de ser a gênese do processo de diferenciação com as demais favelas da metrópole.

Em meados da década de 70, uma professora alemã de linha antroposófica, Ute Craemer, ${ }^{15}$ inicia um trabalho de integração entre alunos de classe média alta da escola Rudolf Steiner, na qual era professora, e as crianças da favela em que atuava, no sentido de conhecer, mutuamente, a realidade de cada um. Este trabalho ganha grandes proporções, culminando na organização de um grupo de pessoas que atuará na favela de forma voluntária, tendo como matriz discursiva a antroposofia. Em linhas gerais, tais práticas antroposóficas delineiam ações assistencialistas e de dependência, aproximando-se em muito das práticas de caridade, que relegam ou até negam as formas de autonomia da população em que se realizam os trabalhos.

Neste período (década de 70 e 80), a inserção de grupos organizados em vários pontos da periferia para realizar algum tipo de trabalho voluntário ou político estava em voga. Estávamos vivendo ainda uma ditadura militar e as formas de organização da população perpassava desde grupos assistencialistas, como os clubes de mães, até os trabalhos da teologia da libertação, da igreja católica, como também, as organizações de esquerda, que haviam sido desmanteladas pela repressão. Cada qual compunha uma

\footnotetext{
${ }^{14}$ Segundo a Sociedade Antroposófica no Brasil, esta filosofia do ser humano remonta ao período do pós primeira guerra mundial na Alemanha. Eles a definem da seguinte maneira: "A Antroposofia, do grego "conhecimento do ser humano", introduzida no início do século XX pelo austríaco Rudolf Steiner, pode ser caracterizada como um método de conhecimento da natureza do ser humano e do universo, que amplia o conhecimento obtido pelo método científico convencional, bem como a sua aplicação em praticamente todas as áreas da vida humana."A Antroposofia é um caminho de conhecimento que deseja levar o espiritual da entidade humana para o espiritual do universo. Ela aparece no ser humano como uma necessidade do coração e do sentimento. Ela deve encontrar sua justificativa no fato de poder proporcionar a satisfação dessa necessidade. A Antroposofia só pode ser reconhecida por aqueles que nela encontram aquilo que buscam a partir de sua sensibilidade. Portanto, somente podem ser antroposóficos pessoas que sentem como uma necessidade de vida certas perguntas sobre a essência humana e do universo, assim como se sente fome e sede." (Trad. de V.W.Setzer)”. www.sab.org.br, consultado em dezembro de 2005.

${ }^{15}$ Ute Craemer, de origem alemã, era professora da escola Rudolf Steiner e morava na Vila das Belezas, onde realizava trabalhos voluntários com a população carente. Ela funda, junto com um grupo de antroposóficos a Associação Comunitária Monte Azul.
} 
matriz discursiva (Sader: 1988) e possibilitava a produção de espaços de sociabilidade, que se transformavam, muitas vezes, em locais de experiências de politização.

No caso da favela Monte Azul, a organização produziu, em conjunto com os moradores, espaços de sociabilidade, que possuíam um caráter diverso de outras organizações, devido ao próprio projeto antroposófico. A inserção de uma organização de alemães, que foi primeiramente realizar um trabalho pedagógico-assistencialista ${ }^{16}$, introduz a favela em um circuito de ações articuladas com sujeitos externos a ela - em sua maioria profissionais liberais pertencentes a classe média, além do Estado, e das empresas privadas, inclusive em um nível internacional. Nesta primeira etapa, tais ações visaram sobretudo melhorias de educação e saúde.

O evento que consolida este momento é a fundação da organização não governamental gerida pelos alemães no ano de 1979. Esta ONG, denominada Associação Comunitária Monte Azul (ACMA), irá canalizar recursos para a favela oriundos de empresas internacionais ou doações. Após alguns anos, com a ampliação dos recursos na década de 80, os trabalhos se estendem a mais dois pontos na periferia da metrópole (Favela Peinha e "Bairro" Horizonte Azul ${ }^{17}$ ). A partir destas ações começam a ser engendradas novas relações dentro da favela, que deixa de ser somente 0 lugar da moradia, para se tornar, a alguns moradores, também o lugar de trabalho e de lazer, já que a Associação criou postos de trabalho dentro da favela para a execução dos serviços oferecidos.

Os trabalhos e a fundação da ACMA marcam o início da territorialização desta Associação no perímetro da favela, a partir da construção de barracões para as creches e o ambulatório, regidos respectivamente, pela pedagogia Waldorf ${ }^{18}$ e a medicina

\footnotetext{
${ }^{16}$ A Sociedade Antroposófica no Brasil relata da seguinte maneira o início dos trabalhos de Associação Comunitária Monte Azul, "Em 1970 Ute Craemer veio ao Brasil, para ser professora de classe na então Escola Rudolf Steiner, onde permaneceu até 1979. Sentindo que sua tarefa de vida estava ligada ao trágico destino dos moradores de favelas brasileiras, começou em 1975 um trabalho social, envolvendo alunos daquela escola, na Favela Monte Azul (que fica ao lado do Terminal João Dias e do Centro Empresarial, em São Paulo ). Seu trabalho, totalmente inspirado na Pedagogia Waldorf e na Antroposofia, provocou uma evolução extraordinária na favela, impulsionada pela criação, em 1979, da Associação Comunitária Monte Azul Em nossa opinião, o resultado mais importante do gigantesco trabalho social dirigido por Ute Craemer, único no mundo, pode ser resumido em uma constatação: é possível dar dignidade ao moradores de favelas e elevar seu padrão de vida se os aspectos cultural e espiritual forem tratados em paralelo com o atendimento das necessidades físicas básicas.”, www.sab.org.br, consultado em dezembro de 2005.

${ }^{17}$ A nomeação de bairro é dada em seu sentido genérico, não enquanto uma noção geográfica.

18 “A Pedagogia Waldorf concebe o homem como uma unidade harmônica físico-anímico-espiritual e sobre esse princípio fundamenta toda a prática educativa Parte da hipótese de que o ser humano não está determinado exclusivamente pela herança e pelo ambiente, mas também pela resposta que do seu interior é capaz de realizar, em forma única e pessoal, a respeito das impressões que recebe. Considera que o homem ao nascer é portador de um potencial de predisposições e capacidades que, ao longo de sua vida,
} 
antroposófica. Tal matriz - a antroposofia - atua diretamente na vida cotidiana, mas é estranha aos moradores da favela, pois tem por base fundamentos de uma outra vivência. Entretanto, ela se insere na vida dos moradores pelos usos que fazem das ações empreendidas pela própria Associação. Nesta atuação, o assistencialismo vai se forjando pelas formas de gestão dos serviços e da própria relação de propriedade dos equipamentos para realização dos trabalhos.

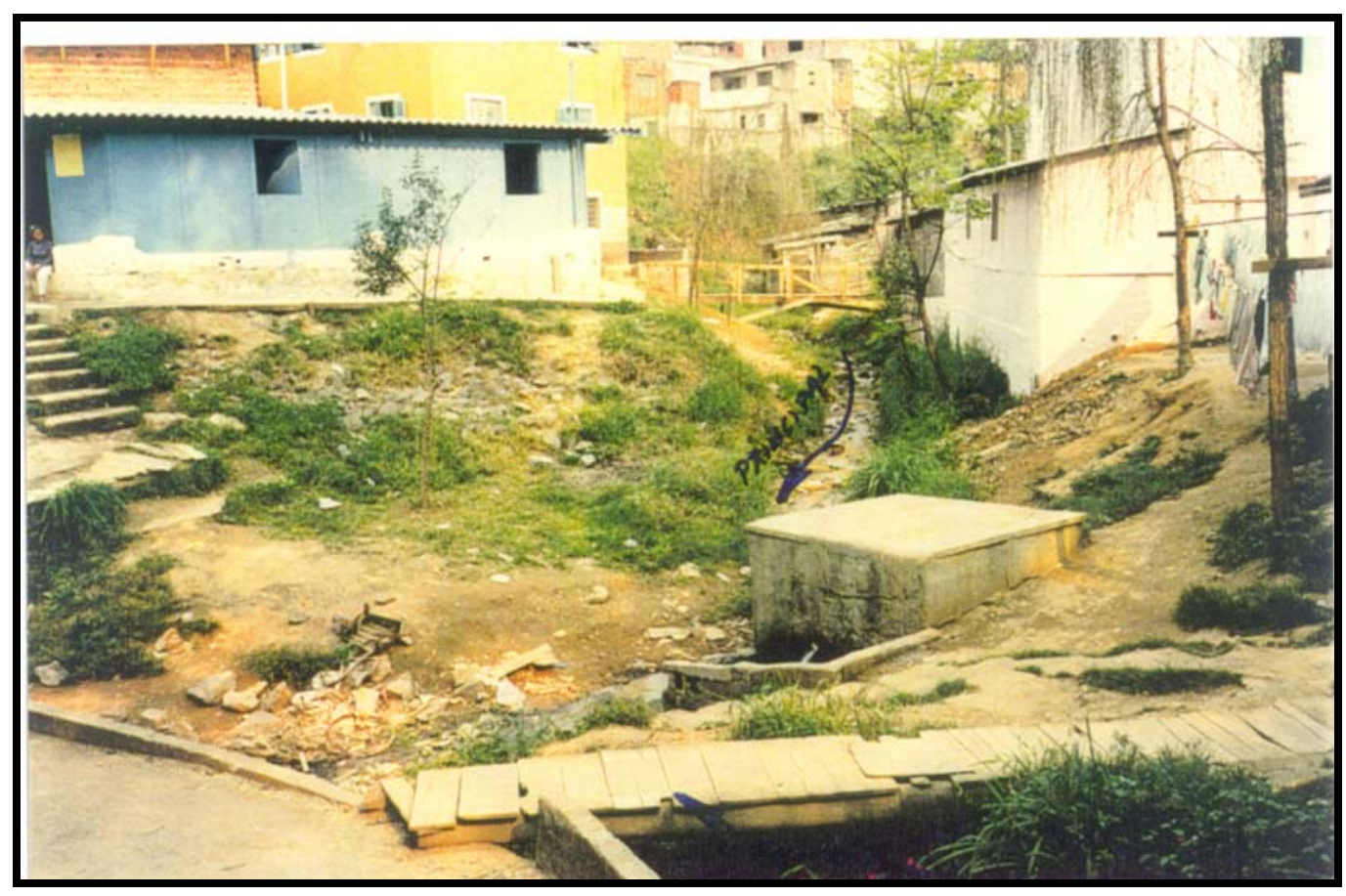

Foto 06 - Barracão e ambulatório construídos sob o sistema de mutirão. Autor: Relatório Bureau - 1992.

Esta relação assistencialista se legitima, pois este projeto da ACMA contém uma perspectiva de trabalho baseada naquilo que há de mais escasso na periferia e basilar à população (saúde e educação). As normas desta matriz vão sendo introduzidas por meio

lutam por desenvolver-se. A educação assim entendida transcende a mera transmissão de conhecimentos e se converte em sustentação do desenvolvimento integral do educando, cuidando que tudo o que se faça tenha como meta a formação de sua vontade e o cultivo de sua sensibilidade e intelecto.” www.sab.org.br, consultado em dezembro de 2005. Quanto a medicina antroposófica podemos mencionar: "O atendimento médico é minucioso e individualizado, baseado na medicina antroposófica, uma ampliação da medicina convencional. Focalizando a doença como parte da biografia individual, o processo de cura é colocado como oportunidade de desenvolvimento.” www.sab.org.br, consultado em dezembro de 2005 
do modo pelo qual os membros da Associação organizavam a população da favela. Tais normas, necessárias para a realização de seu próprio projeto, vão ratificando a sua presença internamente ao convívio dos moradores e da favela.

Nesta primeira década, os trabalhos entre moradores e ACMA são muito estreitos com a construção dos barracões para abrigar os serviços a serem prestados. Os mutirões são mais freqüentes, a presença de membros da comissão de moradores e da Associação em reuniões para trazer infra-estrutura à favela são constantes. O que temos é a ampliação dos trabalhos da ACMA e a melhoria das condições infra-estruturais da favela ao longo dos anos. Estes aspectos quantitativos transformaram a qualidade das relações tecidas no âmbito do lugar, consolidando imbricações e conflitos, que denotam a acumulação das contradições entre os sujeitos implicados na produção do lugar.

A metamorfose da morfologia é visível com a construção dos barracões onde abrigaram o ambulatório e as creches, que, inicialmente, eram de madeira. Uma série de intervenções do poder público local, e parte coordenado pela ACMA é levado a cabo, melhorando as condições infra-estruturais ao longo da década de 80. Um exemplo é a construção de parte dos prédios em alvenaria, substituindo os primeiros.

Quanto ao espaço de uso, no ano de 1983 há a execução de pavimentação de vielas e construção de escadarias através de mutirão e, pela luta ${ }^{19}$ dos movimentos sociais urbanos a Prefeitura lança dois programas: o Pró-Luz e Pró-Água, que serão executados na Monte Azul no ano de 1985. Por fim, neste momento, a inserção do Estado se realiza com o estabelecimento do convênio entre a Prefeitura e a ACMA para atendimento das creches e jardins de infância da área, transformando-se em um dos mantenedores dos serviços alocados na favela.

O que podemos apreender destas ações, que serão explicitadas ao longo da pesquisa, é que há dois processos sendo gestados simultaneamente no período de produção da favela, que se configurariam, mais claramente, enquanto conflitos no momento de reprodução. Ambos se referem a produção da centralidade na periferia. No primeiro processo, a favela e sua Associação se tornam referência para muitos trabalhos do terceiro setor, empresas privadas, e mesmo, o Estado. No segundo, a identidade concreta construída no princípio do encontro entre estes dois sujeitos se diluem com a

\footnotetext{
19 “Os programas de água, luz e melhorias são implantados em um período de ampla mobilização dos favelados que se dirigiam em caravanas ao Gabinete do Prefeito reivindicando a posse da terra e as melhorias de infra-estrutura." Rodrigues, A.M., Na procura do lugar o encontro da identidade: Um estudo do processo de ocupação coletiva de terra para moradia - Osasco, tese de doutorado, Faculdade de Filosofia, Letras e Ciências Humanas - Departamento de Geografia - USP, São Paulo, 1988, pp 169
} 
necessidade de cumprimento das exigências dos mantenedores pela forma convênio introduzindo relações abstratas e, tendo por conseqüência, a constituição de uma identidade abstrata.

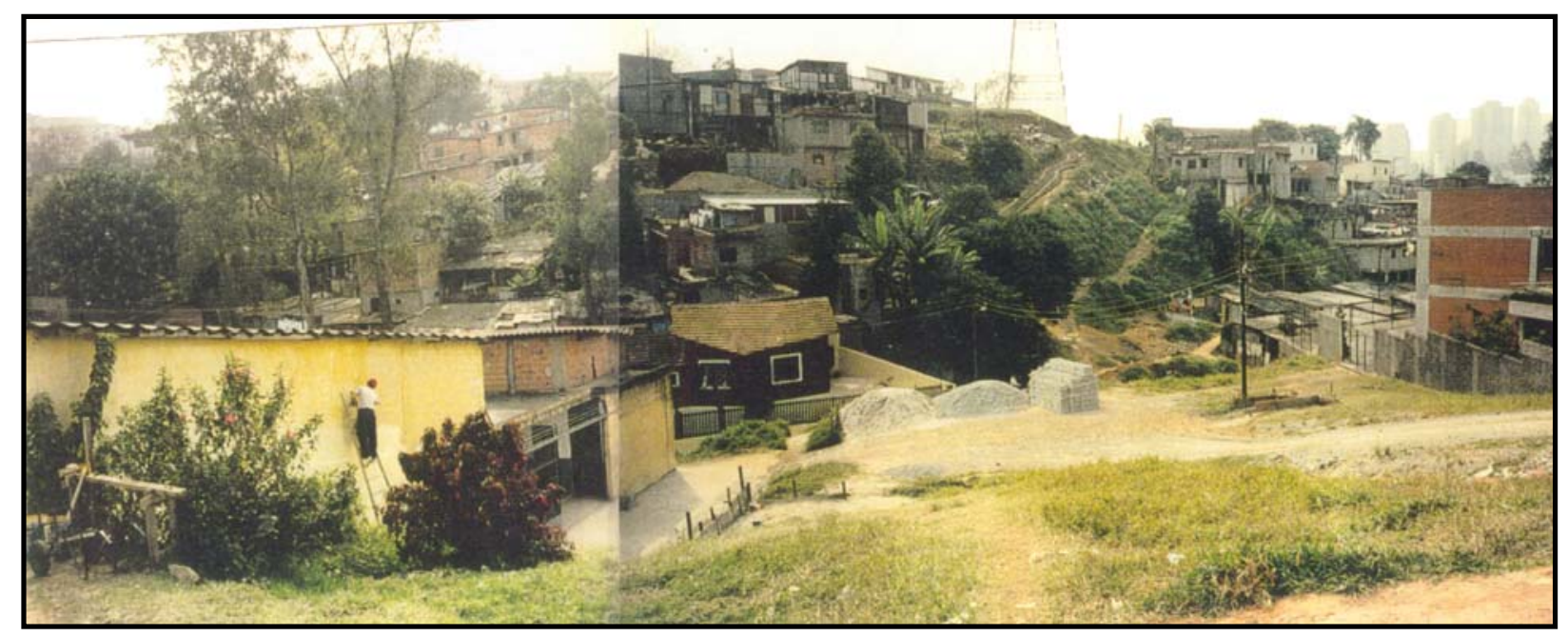

Foto 07 - A morfologia da Favela Período de produção Autor: Bureau - 1993.

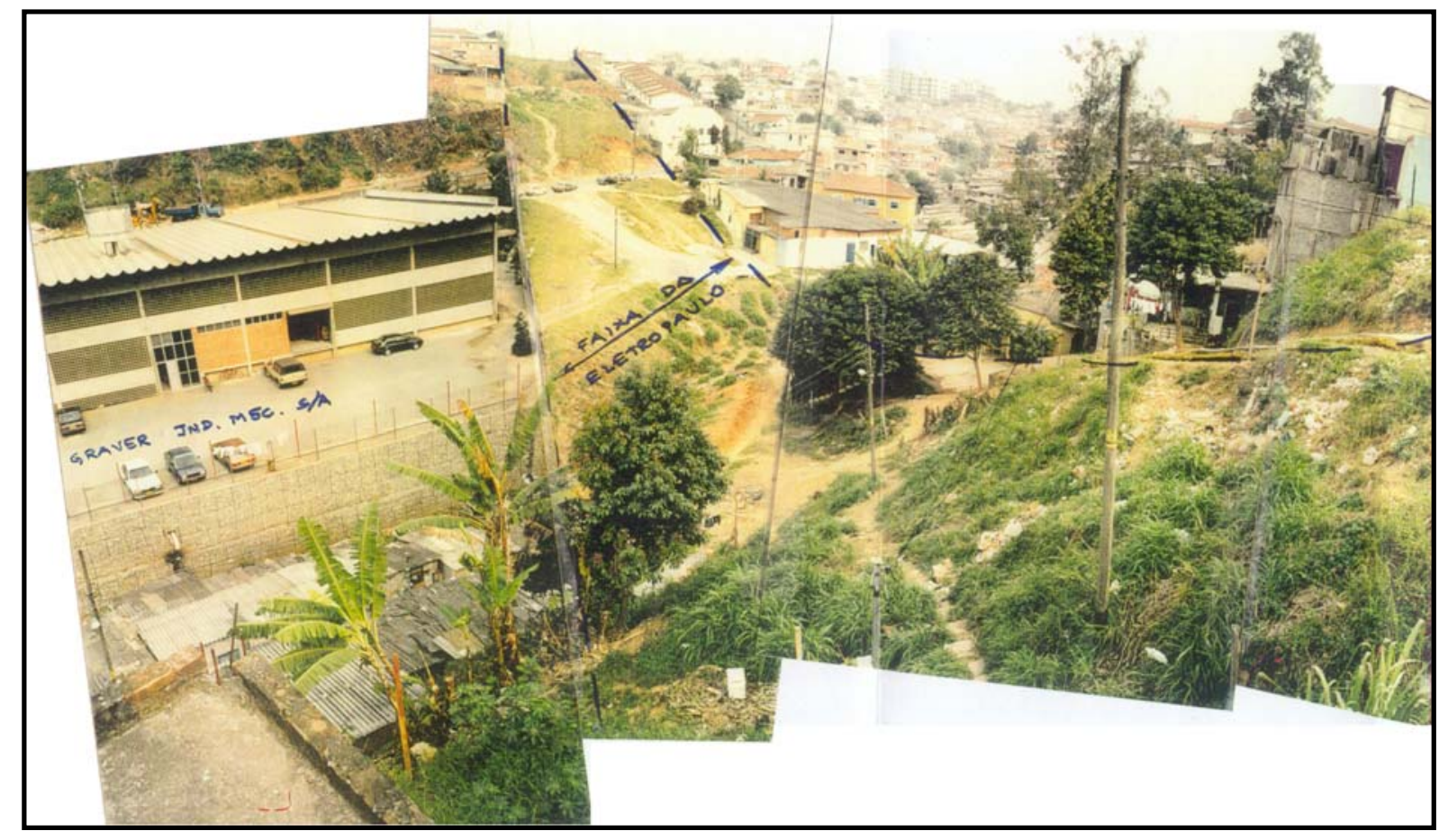

Foto 08 - Panorama da Favela Monte Azul - Período de Produção Autor: Relatório Bureau - 1992. 
Em relação ao primeiro processo, do ponto de vista da Associação, há o crescimento do aparato burocrático necessário para o cumprimento das normas exigidas pelos mantenedores e parceiros, introduzindo as normas destes agentes nas ações da própria Associação. Como esmiuçaremos nos capítulos seguintes, a ACMA necessita cumprir metas estabelecidas por seus mantenedores, o que de certa maneira, a faz subordinar-se a elas para que as verbas não escasseiem. Isto a coloca na posição de iniciar um trabalho de conteúdo mais “eficaz”, ou seja, realizar medidas de inserção de profissionais qualificados, que estejam cumprindo um tempo de trabalho socialmente necessário para dar conta das exigências burocráticas dos financiadores das atividades, por exemplo, o que gera a exigência do direcionamento de parte das verbas para sustentação destes profissionais, que acarreta um impacto nas atividades diretas.

Neste enfoque, a ACMA aponta sua crise, já que seu projeto social é também posto em xeque pela relação espaço-tempo imposta pela ordem distante (instituições mantenedoras), que se traduz pelo crescimento da burocracia interna à Associação.

Do ponto de vista dos moradores, a ampliação das verbas não significa a inserção de todos aqueles que ali residem nos serviços prestados. Isto é, a partir do momento que as verbas provêm de um órgão público - via convênio - o serviço que ele manterá é para toda a população que dele necessitar, o que nos leva a considerar uma dupla conseqüência, a primeira, que se refere a natureza dos serviços ali realizados e a segunda, a interdição ao uso dos equipamentos pelos moradores da favela.

Para a população, os serviços de educação e assistência (creches e atendimento a adolescentes) é de fundamental importância, mas há uma escassez destes serviços na periferia, levando a um afluxo da população para as regiões que os oferecem. À medida que a ACMA passa a proporcionar estes serviços, ocorre um afluxo de pessoas das imediações, o que produz um efeito de escasseamento das vagas oferecidas. Este fato nos remete ao nosso segundo argumento, a impossibilidade de todos os moradores da favela fazerem uso dos serviços prestados no lugar de morada. Um conflito se firma entre os moradores e a ACMA pela impossibilidade de usufruir da infra-estrutura que foi construída coletivamente, enquanto a centralidade deste lugar se produz.

Um segundo processo se realiza, concomitantemente, no momento da produção do lugar, que desembocará no período de sua reprodução. As relações, mesmo que mediadas pelo assistencialismo e dependência da ACMA sobre os moradores, eram em grande parte imediatas, fruto de uma relação espaço-temporal ainda parcialmente desintegrada da lógica do tempo produtivo exigido pelas normas que as mantenedoras 
viriam a impor, permitindo a produção de uma identidade concreta. Esta identidade concreta se produzia com o fortalecimento dos laços entre seus moradores no momento dos trabalhos coletivos, que produziam um espaço de sociabilidade e que possibilitavam o uso daquilo que foi construído em conjunto, como o ambulatório, creches e oficinas. A identidade dos moradores começa a ser produzida, como também, uma identidade do lugar, numa junção com o projeto da ACMA, mas sem construir uma autonomia dos moradores, pois estes últimos não estavam inseridos nos processos de decisão, abrindose, desse modo, um campo para posteriormente fincar as bases de uma identidade abstrata. Pois a identidade se construiu com referenciais externos ao plano do vivido dos moradores, advindos da matriz antroposófica. Entretanto, ainda propiciava uma margem de experimentações, porque o trabalho em mutirões era uma forma de se apropriar do espaço de moradia, bem como, transformava-se em um espaço de sociabilidade. Conforme o crescimento do trabalho da ACMA, que leva a uma ação mais restritiva para garantir os recursos financeiros, há um recrudescimento das experiências coletivas. Os mutirões se reduzem, a mobilização dos moradores para atividades coletivas fica prejudicada.

Houve, com a conjunção destes fatores, a produção de uma identidade abstrata no lugar, porque as relações sociais começam a ser mediadas pelas normas da ACMA, que deve se alinhar à relação espaço-tempo produtivo, reduzindo as possibilidades de relações imediatas ${ }^{20}$, momento que se delineia com plenitude em sua fase de reprodução.

Portanto, se pela perspectiva da ACMA a centralidade lhe permite a visibilidade das ações que empreende e tece um signo para angariar mais recursos para a ampliação de sua atuação, isto se faz pelo empobrecimento das relações da identidade concreta dos moradores, desembocando em uma identidade abstrata.

Argumentamos que se são os usos que tecem a produção da identidade concreta, a partir de uma prática sócio-espacial, ao romper com as formas de atuação mais imediatas se implode a identidade concreta fazendo explodir as bases para as relações abstratas. A prática sócio-espacial estará calcada nos próprios signos, construindo uma cadeia de mediações, que no caso é dada por relações institucionalizadas representada pela ACMA e suas normas.

\footnotetext{
${ }^{20}$ Em uma das conversas com os moradores, houve o seguinte relato "Hoje em dia o pessoal não ajuda muito mais porque eles acham que a Associação virou uma multinacional. Hoje a Associação não procura muito o pessoal da favela, não tem mutirão, acha que associação cresceu muito e não precisa mais da favela”.
} 
Os usos, na perspectiva da apropriação, se reduzem, pois a idéia de apropriação está calcada nas relações qualitativas, em luta com a dominação quantitativa do espaço e do tempo. Ao conquistar determinadas melhorias no lugar, estas concretizadas sob a mediação de normas produzidas externamente, os moradores tem suas vidas reguladas, seja para usufruir dos serviços prestados, seja como mediação para a realização de alguma atividade na favela, como por exemplo, festas juninas.

A legitimação da presença da ACMA no perímetro da favela se justifica também pelas negociações entre a liderança da favela, que exerce influência sobre os demais moradores, servindo como mediador de conflitos intra-favela e estabelecendo normas de convivência. Presenciamos uma somatória de normas articuladas e que regem a vida cotidiana dos habitantes do lugar, revelando a contradição dominação e apropriação do espaço que embasa o conflito pelo uso como veremos no desenvolvimento dos capítulos seguintes.

\section{C- O Momento de Reprodução da Favela Monte Azul: Crises e Territorialização da Associação Comunitária Monte Azul}

Atualmente, a favela vive seu período de reprodução e afirmamos isto, por entender que este momento se destaca pela introdução de políticas públicas “urbanização da favela” e “regularização fundiária”, que transformam radicalmente a morfologia da favela, permitindo outros usos. Entretanto, estes usos vêm acompanhado de um aprofundamento dos conflitos entre os sujeitos, pois há um adensamento dos laços institucionais internos, na medida em que se consolida a territorialização da ACMA, que atualmente, não possui tanta legitimidade como em seu período de produção. Esta legitimidade dada pelos moradores se efetivava conforme as possibilidades de uso destes últimos aos serviços da ACMA.

Uma vez que a centralidade acentuava a procura dos serviços pelos moradores advindos de outros lugares, os da favela se viam privados daquilo existente em seu próprio lugar, rompendo o vínculo que sustentava a presença da ACMA. Até a forma de proposição de projetos a serem realizados com os moradores, principalmente, os jovens, não incorporam as suas necessidades, aumentando o abismo entre a ACMA e os residentes. Se por um lado, isto traz uma recusa dos moradores, por outro, faz a ACMA acirrar as normas para manter a "organicidade" do lugar para a reprodução de suas atividades. O que temos é um acúmulo de tensões, que se expressam muitas vezes em 
ambigüidades entre estes dois sujeitos em destaque, isto é, enquanto um critica a ação de mando do outro, imediatamente, o chama para referendar as ações assistencialistas. O outro, por sua vez, exige uma participação ativa, porém impõe regras, que redundam a uma não participação, assegurando seu poder de decisão. A consolidação destes conflitos encaminhará a um processo de crise como veremos mais explicitamente no capítulo III.

Do ponto de vista da ACMA há a acentuação e consolidação das normas dos convênios $^{21}$ entre o Estado e a iniciativa privada para as áreas de atuação (educação e saúde), o que amplia a burocracia interna. Também, contraditoriamente, à medida que se consolida a territorialização e a centralidade, há uma perda de legitimidade junto aos moradores da favela, pela construção da identidade abstrata, que a coloca em um momento de crise, pois a leva a um processo de dissolução desta própria territorialização.

Do ponto de vista dos moradores, há a consolidação de uma identidade abstrata, que os leva a um distanciamento, principalmente da juventude, em relação as ações da ACMA, conduzindo a um aprofundamento das transgressões às normas ditadas pela ACMA no lugar. Porém, este distanciamento legitima ações de outros sujeitos, que insistem em se territorializar na favela, que podem vir a construir laços ainda mais perversos de dominação e degradação da vida pelo sentido de outras normas a serem inseridas no lugar. Esta passagem pode nos abrir a perspectiva de compreensão de que as ações e os usos não proporcionaram autonomia da população, estando a apropriação sempre vinculada a sujeitos externos à favela.

Portanto, este momento de agudização dos conflitos no lugar representa a crise da reprodução dos moradores, da Associação e da própria metrópole. No destrinchar das estratégias e ações dos sujeitos e instituições implicados na produção do lugar identificamos, anunciamos e resumimos a crise por meio dos seguintes elementos e que serão desenvolvidos ao longo do trabalho:

1 - Na perspectiva dos moradores: a) radicalmente muda-se a prática sócioespacial na metamorfose da morfologia da favela, que se realizou, praticamente, a partir do ano de 2002 pela introdução de uma política pública - "urbanização da favela”. A “urbanização” permitiu a ampliação dos trabalhos da ACMA e a produção de um

\footnotetext{
${ }^{21}$ Os convênios são formas contratuais que possuem diretrizes elaboradas pelo Estado, seguindo a lógica da equalização do desigual, na qual as mesmas regras são válidas para todo o território contribuindo para a homogeneização da vida e do espaço e sucumbindo a diferença. Isto assegura a subordinação da vida social ao conjunto
} 
espaço público para o uso dos moradores. Tal mudança, que fez estender a territorialização da ACMA, implicou em necessidades de cumprimento de normas pelos moradores para a manutenção dos convênios e continuidade do crescimento dos serviços oferecidos pela ACMA. Isto é, os marcos institucionais territorializados a partir do final da década de 70 ganham agora, contornos que interferem de forma mais intensa; b) A reprodução da ACMA coincide com a reprodução dos moradores, carregando, portanto, as crises de "sustentabilidade" e de dominação do espaço. A Favela transformou-se, com a ampliação dos serviços da ACMA e a introdução de políticas públicas, em um lugar que não se restringe ao morar, ao momento do privado, mas também, para parte dos seus moradores, é nela que se efetivam os momentos de trabalho e de lazer. Ao englobar estes momentos, contém, igualmente, as determinações das normas necessárias para a reprodução destes níveis. Fortalecendo, num certo sentido, as relações de dependência produzidas com a inserção do trabalho da ACMA na favela. c) Esta dependência demonstra o cerceamento da produção de relações de solidariedade ${ }^{22}$ e coletividade entre os moradores da favela; d) Tais fatores engendram a possibilidade de inserção de sujeitos que de certa forma dissolvem as normas da ACMA e impõe outras ainda mais restritivas; e) a afirmação da centralidade deste lugar se coaduna com a redução de acesso aos serviços prestados pela ACMA.

2 - Do ponto de vista da ACMA: a) Há a necessidade de aumento do aparato burocrático, calcado num espaço-tempo produtivo, para garantir o fluxo de verbas das instituições mantenedoras e parceiras, recuando/rompendo com as relações imediatas com a população beneficiada pelos serviços, na medida em que há a ampliação das normas que regulam o uso; b) Há, mesmo com os esforços e adequação da ACMA, a diminuição de verbas vindas de outros países e de empresas nacionais, transformando-se numa crise de "sustentabilidade” da Associação. Isto implicaria na dissolução dos trabalhos realizados na favela, e aprofundamento da entrada no espaço-tempo produtivo; c) As normas dos convênios - sejam eles com a iniciativa privada ou com o Estado - muitas vezes atravessam o projeto da ACMA reduzindo as potencialidade de

\footnotetext{
${ }^{22}$ Bensaid, em seu livro Cambiar el Mundo, discorre sobre as crises nas quais nos instalamos na mundialização do capitalismo. Dentre elas está aquela de cunho social, pois a racionalidade capitalista reduz tudo, inclusive, as relações sociais, ao tempo de trabalho abstrato. Isto redundará num aumento da exploração do trabalho, pela concorrência entre os trabalhadores por um posto de trabalho, permitindo uma precarização do trabalho ainda maior. Mas não somente isso, afirma que "a concorrência de todo o mundo contra todo o mundo destrói as relações de sociabilidade e de civilidade”pág.28, desintegra a solidariedade social. A dependência mencionada significa o reforço do processo exposto, e por outro lado, contribuição para a generalização das relações mercantis e consumistas. São, portanto, formas que impedem a produção de relações de solidariedade no âmbito da favela.
} 
suas ações; d) Um outro elemento da crise vem das pressões advindas de novos sujeitos - ligados ao tráfico de drogas, que se apresentam como barreiras aos trabalhos efetuados, dificultando a reprodução da ACMA; e) Efetiva-se um afastamento da ACMA em relação à população, que lhe proporcionou a marca distintiva de sua atuação, e desse modo, pelo assédio deste lugar por outros sujeitos que se inserem no lugar, a fragiliza e questiona a própria territorialização, pois a população não lhe atribui a mesma legitimidade de outrora.

Neste momento de reprodução da favela, acentuam-se os processos de produção da identidade abstrata, decorrente da forma como se produziram os referenciais da favela. Ou seja, os referenciais se realizaram na mediação institucional, que como já foi dito, se alicerçava em relações assistencialistas e de dependência. Estes vínculos, normatizados pelas relações de dependência, limitam, alienam ou mesmo reduzem ao mínimo, a identidade concreta dos habitantes com o lugar. Pois os projetos não são construídos a partir dos anseios e experiências concretas da população, e sim, do projeto daqueles que coordenam a ACMA, hoje pautadas, nas relações espaço-temporais regidas produtivamente, isto é, “eficazmente” para prestar as contas exigidas pelos mantenedores.

O espaço de sociabilidade se constrói sobre as bases destas normas, e as experiências de politização ${ }^{23}$ existentes nas histórias dos movimentos sociais urbanos em São Paulo se realizaram precariamente na Favela Monte Azul, empobrecendo a produção da identidade concreta, como também, transformando-se numa restrição à concretização de relações de coletividade. As experiências se assentaram na incorporação dos valores preconizados pelos antroposóficos, impedindo a reelaboração desta matriz discursiva pelos moradores, que se integravam a ela. As ações não propiciavam autonomia, pois as instâncias de decisão não pertenciam ao coletivo condição necessária para a efetivação da territorialização da ACMA na favela conforme seu projeto. Talvez, isto seja um caminho de compreensão das dificuldades de

\footnotetext{
${ }^{23}$ Eder Sader, em seu livro de referência a todos aqueles que trabalham com movimentos sociais e ações coletivas (Quando Novos Personagens Entraram em Cena), menciona o papel das experiências de politização da vida cotidiana necessárias para a reelaboração das matrizes discursivas em que foram gestados os movimentos, dentre elas temos a da Igreja Católica por meio das Comunidades Eclesiais de Base - CEBs. Mas também deixa claro, que isto não fica somente no reino das idéias, estas experiências possuem uma materialidade, portanto expõe "... sua produção e reprodução dependem de lugares e práticas materiais de onde são emitidas as falas.”. Isso demonstra a indissociabilidade da produção das idéias com uma prática sócio-espacial, que se objetiva em experiências de politização da vida dos habitantes da cidade.
} 
mobilização destes moradores diante das lutas por melhorias e, mesmo, da falta de iniciativa da população por projetos coletivos atualmente. Este fato se revela como mais uma faceta da redução das possibilidades de apropriação do espaço.

$\mathrm{Na}$ articulação e nas implicações do movimento de reprodução da metrópole em seu sentido amplo, e do movimento estrito de produção do lugar, é que pretendemos compreender a questão central proposta pela pesquisa: a tendência da degradação da vida e as insurgências diante desta tendência. Contudo, o que descobrimos ao longo da pesquisa de campo é a centralidade de um dos sujeitos implicados na produção deste lugar, elevando-o enquanto elemento fundamental para a compreensão da diferenciação de produção deste lugar, que nos lançou ao entendimento de processos amplos da produção do espaço urbano. Tal diferenciação dada por este sujeito, a ACMA, e as crises na qual quisemos aqui apresentar, nos colocou diante da seguinte questão a ser desvelada: apesar de amplas conquistas de âmbito infra-estrutural, que constatamos pela morfologia atual, e também de serviços, sugerindo uma ampliação dos usos, há concomitantemente, interditos profundos a estes novos usos, que nos fazem considerar uma pratica sócio-espacial, que se baseia numa sistemática ordenação da vida cotidiana dos habitantes. Todavia, a ordenação lógica é perpassada por transgressões, e essa fissura aberta, entre a lógica e as transgressões, perversamente se produz enquanto uma nova forma de dominação do espaço, onde se produz um “vazio” que permite entrar em cena um novo sujeito que está articulado as esferas ilegais da organização social, restringindo ainda mais as possibilidades de apropriação. Este movimento nos revela a introdução da tendência em que atualmente as periferias de grandes metrópoles possuem, a ampliação dos negócios ilícitos e articulados à violência urbana.

Esta questão justificaria o percurso aqui proposto. A compreensão das estratégias e ações da ACMA, com sua estrutura e funcionalidades, que tem um papel fundamental nos vários níveis da análise (econômico, político e social) da produção do lugar. 
A compreensão da morfologia do lugar só possui sentido se incorporada à lógica da produção do espaço ao nível da metrópole, pois as estratégias da ordem distante (instituições/Estado) e da metrópole vão traçando suas marcas no lugar, mobilizando os habitantes e os espaços, integrando ambos a partir das necessidades da reprodução capitalista, como também, desintegrando-os, quando se tornam barreiras. A finalidade da articulação entre a morfologia do lugar e sua área contígua é a de reconhecer que há uma implicação dos espaços, sendo, então, partes constituintes de um mesmo processo, estando profundamente articulados na totalidade da metrópole.

Este movimento, que é abstrato, mas incide no lugar concretamente, pode ser visto por meio das funções das infra-estruturas e equipamentos produzidos para viabilização dos negócios (como das ONGs, como por exemplo a ACMA), que atinge a vida dos moradores metamorfoseando-as e engendrando a transformação da metrópole.

O processo hegemônico, que produz estas transformações, está baseado nas determinações da reprodução capitalista, que o estrutura, na medida em que atribui funções aos lugares da metrópole. Este espaço, produzido por uma lógica fragmentária, homogênia e hierárquica, pela própria lógica de reprodução capitalista, se confronta com as formas de produção da vida.

A cidade de São Paulo, impulsionada pelo processo de industrialização, começa a se "rearranjar" para comportar os novos espaços-tempos advindos desta atividade. Incorpora os trabalhadores às fábricas, que se abrem no início do século $\mathrm{XX}$ e, leva a metrópole à produção de um novo ritmo de vida, marcado pelo relógio. O espaço vai sendo incorporado ao processo produtivo, enquanto os lugares se transformam em objeto dos negócios urbanos e, a cidade vai delineando-se como produto. Ou seja, da predominância do uso passa-se para o da troca, como resultado das planificações lógicas e abstratas descoladas ou em confronto com a produção da vida.

A industrialização - processo gerador e radical de mudança das relações espaçotemporais - conduz, neste momento, a urbanização, até o ponto em que a quantidade de “coisas” produzidas imponham outra qualidade nas relações, produzindo um outro habitante da cidade, ao fixar a lógica que estava presente na fábrica a todos momentos vividos, com relações fragmentadas e homogenizadas, na qual impera o empobrecimento da vida em seus aspectos material e humano. 
Desse modo, a cidade é produzida sob a tendência de implosão-explosão, apreendida pelo alargamento do tecido urbano, em uma avassaladora periferização, entendida enquanto produto direto da industrialização e da ampliação dos negócios do urbano.

Um outro fator a considerar no plano da metrópole quanto às metamorfoses do espaço-tempo, e que se articula à industrialização, são as mudanças nos sentidos do centro, que de histórico se transforma em centro de poder, reunindo informações, equipamentos e, os instrumentos para a viabilização da reprodução capitalista, bem como, sua manutenção. Tal reunião pode nos encaminhar ao arranjo da relação centroperiferia - produto da industrialização -, considerando-a em um sentido amplo, isto é, na lógica das centralizações, como necessidade da reprodução da sociedade. Esta é uma idéia que pretende ser desenvolvida no capítulo seguinte.

Do momento crítico, de implosão-explosão da cidade, surge, o que Lefebvre denomina de sociedade urbana. Tal momento reúne a centralização de poder econômico e político, a cisão mais bem elaborada entre dominados e dominantes, uma ideologia que justifica a produção em massa da desigualdade. Tal desigualdade se configura por meio das possibilidades e interditos dos usos, impondo a mediação do dinheiro para o acesso às novas tecnologias que a contemporaneidade nos oferece. O abismo entre dominação e apropriação aumenta e, a cisão se consolida, engendrando as sutis estratégias que se realizam no espaço, tomando-o como instrumento de poder.

Esta desigualdade pode ser vista na produção cada vez maior de favelas que datam da década de 40, período de colapso da forma "aluguel”, pois os salários, cada vez mais reduzidos, não eram compatíveis com as rendas dos trabalhadores para manter os pagamentos. Alguns elementos também viabilizaram esta desigualdade, como a coadunação das novas tecnologias de transporte, que levavam os trabalhadores cada vez mais longe do centro em busca de moradias mais baratas, compatíveis com seus salários. Por outro lado, ampliava-se a atuação do setor imobiliário para a periferia da cidade, incorporando os terrenos que ainda não estavam no circuito da troca, definindo e aprofundando a desigualdade por meio do estabelecimento das regras de acesso à propriedade da terra urbana. A procura pelo local de moradia vai sendo realizada nas “brechas” onde não vigoravam as determinações do valor-de-troca, ou que, naquele momento, seu potencial de entrada a este circuito aparecia de maneira remota.

A favela Monte Azul nasce do movimento de produção da periferia como decorrência da industrialização de meados da década de 60, pela expansão das plantas 
fabris às margens do Rio Pinheiros, na região de Santo Amaro, e pelo engendrar das novas formas de inserção precária ao mundo do trabalho.

Desse modo, pela condição do terreno público, onde o direito de propriedade privada vigora diferentemente e, pela exploração na qual estava sujeito o trabalhador da metrópole, é que se ergue o primeiro barraco da favela Monte Azul no ano de 1965. 
COLOCAR FOTOGRAFIA AÉREA DECADA DE 60 
Neste período, nas proximidades do lugar, existia grandes áreas verdes, pouco arruamento e infra-estrutura incipiente, como podemos notar na fotografia aérea de 1962.

A centralidade de serviços e comércio se encontrava em Santo Amaro, localizado no outro lado do Rio Pinheiros, e que na época já possuía uma ponte de concreto ligando as duas margens. Era em Santo Amaro que estavam os supermercados e serviços, além dos empregos. No bairro de Santo Amaro, próximo a margem direita do Rio Pinheiros, a ocupação ainda não estava em toda sua extensão, o que se vê são grandes terrenos, que posteriormente serviram ao adensamento das plantas de fábricas e novos loteamentos. A autopista da marginal ainda era mão dupla e possuía um aspecto precário.

Já ao lado esquerdo da marginal, havia uma área - considerável para a metrópole - de mata atlântica e de relevo de morrotes. Esta porção da cidade começa a ser cobiçada pelo mercado imobiliário na década de 60. Há a abertura dos arruamentos do bairro Morumbi e Vila Andrade, que serão introduzidos no circuito imobiliário para as famílias de alto poder aquisitivo principalmente. As favelas também estavam presentes, podemos destacar a Favela Peinha, que ocupa um terreno com acentuada declividade, e hoje pode ser vista quando se passa pela Marginal Pinheiros.

Na década de 70, a favela Monte Azul já ocupava parte das margens do córrego, continuando a se adensar. A favela Peinha, que se situa no outro lado da Estrada de Itapecerica, já possuía feições mais distintivas do loteamento vizinho. O desenho dos loteamentos aumenta nas duas margens do rio Pinheiros, e há a duplicação da pista da Marginal Pinheiros, traçando sua via expressa e local. Eleva-se o número de plantas industriais. A vizinhança da favela também se adensa, as ruas antigas são alargadas e novas são abertas. Os loteamentos proliferam-se e os galpões vizinhos, existentes até hoje, já se encontravam construídos. E os barracões para a construção do Centro Empresarial de São Paulo já começam a ser montados. 
INSERIR FOTOGRAFIA AÉREA DA DÉCADA DE 70 
Após 22 anos, podemos verificar pela fotografia aérea de 1994, a quantidade de transformações ocorridas em duas décadas, com a consolidação da ocupação da favela e de seu entorno por loteamentos, com a construção de prédios na região do Morumbi/Vila Andrade, mas ainda com a preservação de parte da reserva de mata atlântica, já que esta serve como diferencial para as vendas dos imóveis nesta localidade. Há a implementação de serviços e comércio, como os grandes hipermercados (Rede Carrefour).

Ocorre a materialização do Centro Empresarial e toda uma infra-estrutura para atendê-lo, consolidando-o, como o Hotel Transamérica, construído exclusivamente para hospedar os executivos que se dirigiam a ele, algo que acompanha, igualmente, a ampliação das vias de circulação para integrar este espaço as redes necessárias para viabilização dos negócios. Constrói-se o complexo viário João Dias, com a produção de uma nova ponte e modernização da antiga, duplica-se a Estrada de Itapecerica e erguem-se as alças de acesso ao Centro Empresarial. Estes acessos facilitam tanto a mobilidade daqueles que fazem os negócios nesta centralidade, como aos que residem na área do Morumbi, com sua centralidade residencial, e se ligam a outras localidades da metrópole.

No caminho estão as favelas, os loteamentos irregulares produzidos através do mecanismo da autoconstrução, que vão incorporando as valorizações das infraestruturas implantadas. Sendo, agora, cobiçadas pelo mercado imobiliário, pois no avanço da urbanização, a periferia de potência de valor, se torna efetivamente um espaço passível de ser introduzido no circuito produtivo, já que hoje reúne as condições necessárias para serem vendidas à fatia da população com poder de compra. 
INSERIR FOTOGRAFIA AEREA DECADA 90 
Na imagem de satélite de 2000, a articulação desta região da metrópole, com sua riqueza e pobreza estampada, mostra a integração com o novo eixo da economia de serviços, que vai transformando São Paulo. A implantação da linha do metrô e sua interligação com a linha de trens da Companhia Paulista de Trem Metropolitano (CPTM) traça o fluxo de trabalhadores dessa região para os prédios modernos das Avenidas Berrini e Brigadeiro Faria Lima, como também, facilita o acesso à Avenida Paulista e ao centro histórico, que preservam a centralidade de escritórios, serviços e conseqüentemente, empregos. Soma-se isto, a estação de metrô, o Terminal de ônibus (João Dias), também vizinho da favela, que possui linhas que trafegam pela Marginal Pinheiros, Berrini, rua Funchal, Avenida Juscelino Kubitschek e Faria Lima. 
INSERIR IMAGEM DE SATÉLITE DECADA DE 2000 
Os negócios imobiliários da região Morumbi/Vila Andrade aumentam, expandindo condomínios fechados e uma série de equipamentos, como supermercados (Carrefour e Extra), shopping (Jardim Sul), etc. Tais transformações produzem espaços extremamente desiguais, como os das favelas e os dos condomínios fechados, por exemplo. Apresenta também, o extremo do processo de segregação sócio-espacial, no qual rico e pobre convivem. Seabra explicita este drama da sociedade urbana quando discute a vida cotidiana como integradora das separações, no que diz respeito aos condomínios fechados

"Intramuros encontram-se uns e outros, os de fora e os de dentro para viver a cotidianidade como fluxo do tempo naquele território que os aproxima. Paradoxal, na separação de uns está a vida de outros tanto. E o drama consiste em que a vida vai sendo transformada sem o saber; que uns se reproduzem nos outros e que parte importante do tempo consomem (ambos) no mesmo lugar, através de vínculos essenciais. Vínculos que transformam uns e outros, embora não transformem da mesma forma e tampouco com o mesmo sentido.”. ${ }^{24}$

E é no revelar da morfologia que vamos decifrando os caminhos da produção do espaço desigual. Assim, Seabra, novamente, nos faz refletir sobre a importância da morfologia:

“... a morfologia social do espaço traduz tendências lógicas e sistêmicas da reprodução da sociedade e que traduz, também, a ação consciente dos agentes que se movem no urbano a procura de negócios, de trabalho ou de lugar, num confronto que se torna muito aberto e no qual se verifica a territorialização das práticas”. ${ }^{25}$

Considerando esta idéia de Seabra e as descobertas encontradas ao longo do percurso da pesquisa, na busca prática e teórica, nos encaminhamos para a compreensão dos sujeitos que inflexionam a produção do lugar, diferenciando-o e transformando-o em uma centralidade na periferia.

\footnotetext{
${ }^{24}$ SEABRA, Odette Carvalho de Lima, Territórios do uso: cotidiano e modo de vida, In: Revista Cidades, Grupo de Estudos Urbanos, vol. 02, Presidente Prudente, 2004, pp. 128.

${ }^{25}$ SEABRA, Odette Carvalho de Lima, São Paulo: a cidade, os bairros e a periferia, In: Geografias de São Paulo: Representação e crise da Metrópole, CARLOS, A. F. A. e OLIVEIRA, A. U. (org.), Contexto, São Paulo, 2004, pp272.
} 
A lógica da produção de centralidades no espaço urbano, a partir da expansão acelerada do tecido urbano, como também, dos sujeitos que as empreenderam, estão no foco da pesquisa capaz de elucidar o significado do movimento de produção do espaço urbano.

O momento de descrição da morfologia (da favela, da área contígua e social), nos lança as indagações a serem desenvolvidas no percurso e na perspectiva da problemática delimitada, bem como, nos propõe uma série de caminhos frutíferos, nos restando a difícil tarefa de escolha.

Valendo-se, então, destas oportunidades, no presente consideramos mais profícuo, por comportar questões vistas como mais relevantes para o aclaramento da problemática e das contradições fundamentais que se eleva a análise, nos debruçarmos nas ações da ACMA e sua territorialização. 


\title{
Capítulo II
}

\section{Da Periferização às Centralidades na Periferia}

\author{
"En dicha sociedad, lo 'real' se encuentra al final y no al principio".
} Henri Lefebvre ${ }^{1}$

Atualmente uma massa crescente da população ocupa as áreas mais precárias da metrópole, constituindo um volume nunca antes visto. A periferia se estende brutalmente e, em grande parte, continua a ratificar os processos de expulsão das frações da população com padrões de renda incompatíveis com a inserção de amplas porções do espaço no circuito da troca. Este fato evidencia que a produção do espaço urbano se realiza produzindo a segregação sócio-espacial (mediada pela propriedade privada do solo), que ao impedir o uso da terra, leva à ampliação a cada dia do tecido urbano paulistano.

A produção da metrópole paulistana pode ser vista neste quadro de degradação da vida urbana por meio dos dados das habitações precárias do ano de 2004. Em uma extensão de $1.509 \mathrm{~km}^{2}$ há mais de duas mil favelas, representando $11 \%$ da população total do município. Muitas delas datam da década de 60 e 70, período de expansão deste tipo de moradia nas áreas que ainda não interessavam ao mercado imobiliário. Outro viés da degradação da vida, visto pelo prisma da moradia, são os loteamentos irregulares, que também dão a feição da periferia paulistana. Estas habitações cobrem o vasto tecido urbano construído aceleradamente após a década de 60. A degradação da vida pode ser vista pelo não acesso às infra-estruturas, pela escassez dos recursos materiais, mas inclusive, pelos espaços de uso e lazer.

Assim, a segregação sócio-espacial imposta à grande parte da população comporta implicações que devem ser consideradas para a compreensão da degradação da vida na metrópole e a sua forma atual. À medida que o tecido urbano se estende, produz-se uma imensa periferia, que se diferencia do centro, seja pelas condições materiais, seja pelas possibilidades de usos dos equipamentos existentes. O espaço capitalista tende a se produzir sob a marca da relação centro-periferia dialetizado pelas centralidades, em uma relação que provém das estratégias sobre este mesmo espaço, confinando grandes contingentes da população que passam a concentrar nas periferias

\footnotetext{
${ }^{1}$ Lefebvre, Henri, El derecho a la ciudad II, Ediciones Península, Barcelona, 1976, pp.42.
} 
das cidades. A concepção de centro neste momento, portanto, se refere à reunião de poder (econômico e político), do qual poucos podem usufruir. Já a periferia é, em parte, compreendida principalmente pela idéia de precarização, isto é,

“ $a$ noção de periferia, na sua generalidade, refere-se à pobreza

geral expressa na falta de meios materiais que suportam a reprodução dos indivíduos com padrões mínimos de dignidade humana."2

Todavia, a relação centro-periferia é vista enquanto lógica e estratégica para a realização da reprodução capitalista, significando que precisamos entendê-la como uma tendência que irá confrontar-se com a prática sócio-espacial, dialetizando o processo de produção do espaço. Ou seja, o centro, subtraído de grande parte da população e ganhando novos conteúdos, precisa ser reproduzido para garantir as condições de reprodutibilidade desta mesma população, mesmo que este processo esteja compassado com a produção hegemônica, pois o centro é condição imprescindível para a realização vida urbana. É desse modo, que o imenso tecido urbano constituído pelas determinações do processo de industrialização se produz produzindo centralidades na periferia.

Essas centralidades na periferia tornam relativo e tentam superar as ambigüidades criadas pela relação centro-periferia. Elas revelam o modo desigual de produção do espaço urbano e as diferenciações resultantes das funções dadas a cada centralidade na lógica das hierarquizações do espaço, e também, envolvem as contradições do espaço, pois ao mesmo tempo em que se nega o centro à maioria da população são criadas centralidades para reunir as condições de manutenção da reprodução das relações de produção. É nesta medida que Damiani constata que:

“A urbanização é um fenômeno mundial, enquanto tal é homogêneo, mas concretamente se realiza através de diferenciações do espaço, periferias diferenciadas nas centralidades, também diferenciadas, ambas provisórias, podendo constituir novas periferias e novas centralidades.” ${ }^{3}$

Ao observarmos São Paulo, verificamos uma série de centralidades, cada qual com um conteúdo e uma função articulada às demais áreas da metrópole, caracterizando-a numa policentralidade. Isto implica na implosão do centro histórico da cidade, ao mesmo tempo em que se dissemina por toda a extensão da metrópole

\footnotetext{
${ }^{2}$ Seabra, Odette, Territórios do uso: cotidiano e modo de vida, In: Revista Cidades, Grupo de Estudos Urbanos, vol. 02, Presidente Prudente, 2004.

${ }^{3}$ Damiani, Amélia, A crise da cidade: os termos da urbanização, In:Carlos, A. F. A., Daminai, A., Seabra, O. L. S., O espaço no fim do século: a nova raridade, Geousp Abordagens, Contexto, São Paulo, 1999.
} 
centralidades que cumprirão o papel de mediação entre a ordem distante (instituições/Estado) e a próxima (lugar do vivido), bem como, centralidades que alcançarão outras já constituídas historicamente, lhes atribuindo um novo significado. Portanto, constatamos que a metrópole produz uma forma polinucleada, evidenciando esta que é uma particularidade da urbanização contemporânea.

Mas, cabe perguntar qual é o conteúdo desta forma polinucleada, bem como qual é o fundamento da produção do espaço urbano que resulta na produção destas centralidades. E, se o processo de urbanização se constitui sob a égide da relação centroperiferia na medida em que expulsa parte da população para as “franjas” periféricas, quais seriam as implicações e decorrências da constituição de centralidades na periferia? E, por fim, qual o conteúdo destas centralidades na periferia?

Para tentar responder as essas perguntas, iniciamos nossa argumentação a partir das idéias apresentadas por Rocha (2000), que considera a produção da metrópole como produto não somente da reunião de objetos materiais, mas como algo que comporta a produção e reprodução das relações de produção, portanto, as relações sociais. Na medida em que apreende a produção, este processo incorpora e coloca em primeiro plano a noção de produção e reprodução das relações sociais de produção abarcando a totalidade da metrópole e não apenas o espaço produtivo strcito sensu.

$\mathrm{Na}$ perspectiva de Rocha, estas relações se realizam sob a tríade dominação/coação/segregação que representa um movimento estratégico e lógico da reprodução capitalista, que surge como base da relação centro-periferia. Esta lógica contém os impedimentos para a realização do direito à cidade, identificados na pesquisa através dos processos de degradação da vida urbana. Entretanto, mesmo que o espaço urbano se constitua sob a relação centro-periferia, na qual o centro histórico adquire outros conteúdos, principalmente atrelados ao poder de decisão político e econômico, o centro continua a ser necessário para a realização da vida urbana, e esta necessidade faz erigir centralidades funcionalizadas na periferia a fim de manter a reprodução das relações de produção, relativizando a relação centro-periferia. De acordo com Rocha,

“Esta dicotomia [centro-periferia] já contém uma série de implicações. Nesta lógica formal - o dilema centro-periferia - encontramos o elemento de sua superação, a centralidade, que relativiza o sentido formal dos dois termos, apresentando-se como uma qualidade, um adjetivo espacial, aliás, a metrópole pode ser considerada resultado da adjetivação centralidade, pois é isto que a caracteriza, a policentralidade. Pela relatividade que a 
centralidade trás consigo não temos um único centro, o centro explodiu, temos vários centros, tantos quantos as atividades, os objetos e as situações demandarem.

Mas esta relatividade do centro que a centralidade introduz está condicionada às forças que agem na sociedade. O econômico e o político continuam tendo preponderância sobre o social, e nesta preponderância, as estratégias de dominação/coação/segregação regem a sociedade. A articulação destas três práticas é a base dos impedimentos do direito à cidade e a outros direitos para a maioria da população metropolitana."4

Sob este prisma, tentamos construir algumas reflexões que alicerçam a compreensão das questões postas neste capítulo e que acreditamos que se aproximam do conteúdo das degradações da vida na metrópole e as suas transgressões. A hipótese que orienta este capítulo (bem como a pesquisa como um todo) é que a vida urbana necessita de um centro para se realizar. Este centro, na história, obtém inúmeros conteúdos, e com o processo de periferização há a elaboração de outros novos, na medida em que se instauram as centralidades na periferia. Tais centralidades se constituem para levar a cabo não somente a produção stricto sensu, mas também, para manter a reprodução das relações de produção sob a égide da reprodução capitalista. Suas estruturas comportam diferenciações funcionais, como produto da tendência de produção do espaço urbano no capitalismo realizada através da fragmentação/homogenização/hierarquização deste, como também, incorporam práticas que advém de lógicas não hegemônicas, e desse modo, confrontam-se com os demais espaço-tempos existentes no plano da metrópole pela prática sócio-espacial dos habitantes.

Assim, uma vez que "o objeto se inclui na hipótese, ao mesmo tempo, em que a hipótese refere-se ao objeto" (Lefebvre; 2002), a Favela Monte Azul e a Associação Comunitária Monte Azul, que juntas formam o objeto específico da pesquisa, revelam a produção do lugar enquanto produção de uma centralidade na periferia, que possui um conteúdo específico dentre as inúmeras centralidades. Estes conteúdos atribuídos pela

\footnotetext{
${ }^{4}$ Rocha, Alexandre, Centralidade e Periferia na grande São Paulo: Abordagem critica sobre o morar na periferia da metrópole, dissertação de mestrado, FFLCH/DG, São Paulo, 2000.
} 
gama de ações realizadas no lugar impõe uma lógica de inserção à cotidianeidade ${ }^{5}$, interferindo diretamente nos momentos da vida cotidiana dos moradores.

Isto nos leva a elaborar uma hipótese secundária, segundo a qual a produção desta centralidade só se realiza com a territorialização de sujeitos institucionalizados (Igreja, ONGs, Associação Amigos de Bairro, etc), que tornam-se instrumentos de mediação a serviço de instituições e do Estado (ordem distante) com o objetivo de regular o lugar e reproduzir as relações de produção. Tal territorialização se realiza, destacadamente, pela gestão e propriedade dos elementos que atribuem os conteúdos de centralidade na periferia, e, portanto, o espaço aparece como instrumento político a ser considerado.

Deste modo, a prática sócio-espacial dos sujeitos implicados na produção do lugar revelam as ações de realização da estratégia de reprodução das relações sociais de produção, assim como os conflitos decorrentes destas imbricadas relações. As relações de poder tecidas ao nível do lugar, demonstram os processos sutis de dominação do espaço por uma organização não governamental com a realização do projeto antroposófico, mas também, as transgressões dos moradores diante deste aparato institucional.

Ao nível da metrópole, a centralidade produzida revela a lógica hegemônica de produção do espaço urbano, pois ela só se constitui como tal conforme os conteúdos dados pelo seu entorno. Tal produção hegemônica do espaço promove a periferização e as degradações da vida urbana, evidenciando a sobreposição do valor-de-troca sobre o valor-de-uso no processo de urbanização, pois a finalidade da produção do espaço capitalista é alcançar rentabilidade em detrimento do usufruir. A problemática urbana destacada é o empobrecimento das possibilidades de apropriação do espaço diante das relações de poder impressas e realizadas no espaço.

Cabe, então, compreender o movimento tendencial de produção do espaço urbano e as contradições presentes neste processo, e por esta razão, introduzimos a reflexão sobre os aspectos do fundamento da lógica da produção do espaço capitalista, pois a partir dela revelamos o fundamento dos conflitos na urbanização, nomeadamente a contradição uso-troca.

\footnotetext{
5 "Essa época teve o seguinte resultado: a constituição de uma cotidianidade, lugar social de uma exploração refinada e de uma passividade cuidadosamente controlada. A cotidianidade não se instaura no seio do 'urbano' como tal, mas na e pela segregação generalizada:a dos momentos da vida, como a das atividades.” Lefebvre, H., A revolução urbana, 2002, pp129.
} 


\section{O Espaço como Condição, Meio e Produto da Reprodução da Sociedade}

“O homem se apropria do mundo como apropriação do espaço - com todos os seus sentidos, isto é, com todo o seu corpo.”6

A produção do espaço geográfico é inerente à produção da vida. A sociedade, por meio de sua relação com a natureza mediada pelo trabalho espacializa suas relações sociais, e na medida que o faz, torna-se o sujeito produtor do espaço. Desse modo, a geografia se transforma em uma ciência que nos encaminha à compreensão da produção deste espaço social produzido, mas que também permite entender que o espaço se torna a condição, material e abstrata, da realização da reprodução da sociedade, tendo-o como meio para realizar a vida. Isto é, a produção do espaço

"Refere-se ao fato de que os homens, ao produzirem seus bens materiais e se reproduzindo como espécie, produzem o espaço geográfico. Entretanto, dependendo do momento histórico o fazem de modo específico, diferenciado de acordo com o estágio das forças produtivas. O espaço passa a ser produzido em função do processo produtivo geral da sociedade."7

O espaço, apreendido nestes termos, nos remete a uma totalidade dos processos sociais em seus três níveis (econômico, político e social) que, por sua vez, estão articulados e justapostos nas dimensões do local, da metrópole e do mundial. É a partir da reunião destes níveis e dimensões que caracterizamos, destrinchamos e apreendemos os sentidos das relações existentes em cada espaço-tempo.

Essas idéias expressas acima nos permitem situar a contribuição da geografia para o entendimento dos conflitos e contradições existentes na sociedade, na medida em que superamos a organização do espaço em si, e descobrimos o caráter social desse objeto a partir dos sujeitos que o produz. Ou seja, cabe à geografia compreender a espacialização das relações sociais, pois a objetivação dada pelo trabalho humano é em si a produção de espaço, e este último ganha múltiplos sentidos pela relação construída na mediação do trabalho.

Este espaço entendido como condição, meio e produto não se produz somente por um sujeito ou apenas de uma determinada maneira, pois há a simultaneidade de espaços-tempos, que traçam as qualidades dos espaços existentes, mesmo que estes

\footnotetext{
${ }^{6}$ Carlos, Ana Fani Alessandri. Espaço - tempo na metrópole, Contexto, São Paulo, 2001.

${ }^{7}$ Carlos, Ana Fani Alessandri, A (re)produção do espaço urbano, Edusp, pp22.
} 
estejam sob uma lógica hegemônica. Os sujeitos existentes na sociedade são múltiplos, cada qual apresentando uma forma de apreensão da realidade e caracterizando um mosaico de relações dadas pelas estruturas e funções existentes nos momentos da história, e este últimos são constituídos a partir do modo de apropriação da natureza através do trabalho. Esta multiplicidade de sujeitos também nos encaminha à compreensão das diversas finalidades de produção deste espaço para garantir as condições de reprodução de cada sujeito, o que demonstra que a sociedade não é homogênea, e sim, que há objetivos e finalidades diversos com processos justapostos, além dos sujeitos apresentarem-se profundamente imbricados um com os outros, evidenciando que o espaço se diferencia na articulação entre os vários níveis da realidade.

Em nosso período histórico vivemos sob uma lógica hegemônica de produção do espaço, que se choca, pela prática sócio-espacial, com os espaços-tempos anteriores. Ou seja, em uma sociedade dividida em classes sociais, na qual uma minoria detém os meios de produção e a outra se qualifica somente por possuir a força de trabalho, uma contradição torna-se a fundamental para o entendimento do significado da produção do espaço. Tal contradição se expressa nos seguintes termos:

“O espaço produzido pelo capital fundamenta-se na apropriação privada, que aliena do produtor o produto; nesse sentido, o espaço se produz a partir da contradição entre sua produção socializada $e$ apropriação individual. Essa contradição aparece no uso do solo, pois para viver o indivíduo ocupa determinada parcela do espaço." 8

Ela irá perpassar e se aprofundar com o desenvolvimento deste modo de produção até o ponto de produzir um espaço específico. É preciso, então, desenvolver a idéia da lógica hegemônica à qual a sociedade e seus espaço-tempos se subordinam.

\section{A Mercadoria e o Espaço-Mercadoria}

Marx apresenta no primeiro parágrafo do capítulo 1 d’O Capital' a forma da riqueza da sociedade capitalista: a sua “imensa acumulação de mercadorias”. É a partir desta forma elementar - a mercadoria - que ele inicia sua análise sobre o modo de acumulação, destrinchando suas formas de valor-de-uso e valor-de-troca, e é nesta dupla determinação, que estão em permanente conflito, mas que se produzem

\footnotetext{
${ }^{8}$ Carlos, Ana Fani Alessandri, A (re)produção do espaço urbano, Edusp, pp 22.
} 
simultaneamente, que vislumbramos os rumos dessa sociedade. Na medida em que se generaliza e penetra nas relações sociais, a mercadoria vai dilacerando a vida dos homens, reduzindo-os também a meras mercadorias (força de trabalho), pois o que importa é a potência de valorização do capital. Desse modo, tanto a produção de “coisas” quanto a produção do homem se realizam na toada da generalização da mercadoria.

Segundo Carlos "a coisificação das relações sociais que ocorre no processo produtivo, desumaniza e desvaloriza o homem em detrimento do objeto criado, cuja a posse significa riqueza e poder."9

Esta generalização não significa apenas uma relação de troca strcito sensu, pois o sentido deste ato da troca representa a generalização de uma relação contraditória e redutora da interação entre os sujeitos implicados no ato da troca.

Para destrincharmos esta relação nos apoiamos nas idéias de Lefebvre, segundo o qual há momentos na realização deste ato redundando na coisificação desta relação. Assim, a troca material é vista em três dimensões ou momentos, a primeira se refere ao deslizamento fora da consciência, no qual “ $A$ 'coisa' adquire uma tal importância que ela reduz, dissimulando-a, a relação entre os sujeitos"10; a segunda é o acordo estabelecido por aqueles que realizam a troca na forma contrato, que estipula uma forma de equivalência (dinheiro) e por fim, a terceira dimensão é a da coação inerente à troca, pois ao estabelecer o contrato, igualamos o desigual sob as regras morais, sociais e políticas, aparecendo como produto social a desigualdade. Estas regras são o que normatizam os usos, empobrecendo-os diante dos desejos dos habitantes. Elas provém de uma ordem distante, abstrata, e se realizam concretamente no plano do vivido, muitas vezes estranho às relações imediatas.

Na generalização da relação de troca, as “coisas” estão em primeiro plano e o diálogo se faz pelas referências de medida (quantidade). A qualidade do produto, a finalidade de seu uso aparece empobrecida frente a este ato, e com importância reduzida em um mundo no qual as mediações das “coisas” vão se sobrepondo as relações imediatas entre os sujeitos. O movimento de generalização da mercadoria e seu ato de troca intrínseco transformam a contradição uso-troca em um conflito real.

\footnotetext{
${ }^{9}$ Carlos, Ana Fani Alessandri, A (re)produção do espaço urbano, Edusp, São Paulo.

${ }^{10}$ Lefebvre, Henri, Capítulo 2 - O ato da troca material, A Respeito do Estado, tomo III O Modo de produção estatista, tradução: Oseki-Depré, I, Nasser, a., Andrade, M. e Oseki, J.pp.07.
} 
“O valor-de-troca estabelece sua preponderância no decurso de uma luta feroz contra o valor-de-uso, após tê-lo constituído como tal e sem jamais se separar dele. A troca extrai o uso de seus limites, mas também do gozo imediato." 11

Este ato da troca se estende com a coadunação da forma propriedade privada, na medida em que alimenta a transformação do homem em simples força de trabalho, reduzindo-o a mercadoria. A força de trabalho se torna também intercambiável, medida pela abstração produzida pela rede de equivalências estabelecidas social, política e moralmente.

"A igualdade dos trabalhos humanos fica disfarçada sob a forma da igualdade dos produtos do trabalho como valores; a medida, por meio da duração, do dispêndio da força humana de trabalho toma forma de quantidade de valor dos produtos do trabalho; finalmente, as relações entre os produtores, nas quais se afirma o caráter social dos seus trabalhos, assumem a forma de relação social entre os produtos do trabalho." 12

A finalidade inicial da força de trabalho do homem voltadas para a realização de suas necessidades imediatas, para fruição se esvai com a sua expropriação pela introdução da propriedade privada. A imposição da relação da troca o faz introduzir no mercado esta única mercadoria que possui. A qualidade se transforma em quantidade no momento em que o trabalho passa a ser mediado pelo tempo socialmente necessário para a valorização do capital, e o homem, reduzido ao mínimo de suas potencialidades, constrói uma história de perdas e reduções, conforme ocorre a extensão da generalização da mercadoria. Para Bensaid:

“La propriedad, solidaria con la lógica mercantil y la acumulación del capital, determina la sustracción de los médios de producción a los trabajadores, el fetichismo de la mercancia y la reificación de las relaciones sociales." 13

Isto é, a relação de propriedade se torna fundamental para o empreendimento capitalista, pois é ela que garante e mantém, ao se associar a outros elementos como o espaço, as perdas dos homens e sua sujeição ao capital. Ela permite a predominância das

\footnotetext{
${ }^{11}$ Lefebvre, Henri, Capítulo 2 - O ato da troca material, A Respeito do Estado, tomo III O Modo de produção estatista, tradução: Oseki-Depré, I, Nasser, a., Andrade, M. e Oseki, J.pp.11.

${ }^{12}$ Marx, K., O Capital, Livro I: O processo de produção do capital, $5^{\text {a }}$ edição, Civilização Brasileira, Rio de Janeiro, 1980, pp. 80.

${ }^{13}$ Bensaid, Daniel, Cambiar el mundo, Catarata, Madri, 2004, pp 28.
} 
relações mediadas pelas “coisas” (mercadorias), já que a troca é a forma primordial de relação entre os homens. Por isso, no momento de avanço do capital mundialmente, nos deparamos com a avassaladora concentração dos bens, inclusive do espaço, como o próprio Bensaid (2004;28) aponta,

“la 'globalización’ significa uma concentración sin precedentes de la propriedad privada de los médios de producción, de información y de intercambio y de los poderes reales de decisión y coerción. Estamos en la era de la mercantilización y la privatización del mundo. Ambas van de la mano. Y no se trata solo de la privatización de las industrias y de los servicios, sino que se privatizan los seres vivos, el saber, el água, el aire, $\underline{\text { el }}$ espacio, el derecho, la informción, las solidariedades, al igual que se privatiza la violência y la guerra, con empresas mercenárias que se cotizan em bolsa."[grifo meu]

Neste movimento, o espaço entra no circuito da mercadoria e da troca como propriedade daqueles que possuem os meios de produção, transformando-se pela troca, em um instrumento de subordinação dos homens que possuem somente sua força de trabalho como equivalente para se introduzir no mundo do consumo. Ele se torna objeto de acumulação da reprodução capitalista e possibilidade de mitigação das contradições desta própria acumulação. Transforma-se, portanto, no lugar privilegiado das ações estratégicas da reprodução das relações de produção.

A produção do espaço se insere, hegemonicamente, na lógica da acumulação e a contradição uso-troca se estende por ele. E uma vez subordinado à troca, o espaço se fetichiza e esconde os mecanismos de sua real produção. As mediações, de poder, de controle, das territorializações realizadas pelas estratégias de dominação para mantê-lo no circuito mercantil, implicam na degradação da vida dos habitantes que nele residem. E esta degradação física e social dos habitantes se apresenta na desigualdade da morfologia material como também na morfologia social.

A degradação e a desigualdade são produtos das relações de equivalência, da métrica, daquilo que o indivíduo, reduzido à força de trabalho, representa enquanto rendimento no processo de acumulação. Mas, estes dois processos não se realizam sem as insurgências daqueles que sofrem o peso da quantificação e abstração de suas vidas, como veremos adiante. 
O espaço mercadoria, incorporado com toda sua potência de realização de acumulação capitalista, possui como marco o processo de industrialização. Suas implicações indicam que

"através de um imenso processo, o capitalismo se apoderou da cidade histórica, fê-la explodir, gerou um espaço social que ocupou, continuando sua base material a ser a fábrica e a divisão técnica do trabalho no seio da empresa. O resultado disto foi uma vasta deslocação das contradições..."14

A industrialização seria o ponto de partida da produção de um espaço direcionado à finalidade da troca e, por sua vez, da acumulação. No caso da cidade de São Paulo, sua “explosão” em imensas periferias se realiza no momento em que se avoluma a mobilização de pessoas, produtos, dinheiro e capital para alavancar o processo industrial, já nos fins do século XIX. A propriedade privada da terra, como condição necessária ao pleno desenvolvimento da acumulação capitalista, é promulgada algumas décadas antes (1850), e se caracteriza de modo específico no Brasil, ou seja, a terra torna-se reserva de valor, forma de subordinação do trabalho ao capital (capitalismo rentista $)^{15}$. Isto viria a implicar na concentração fundiária, que se arrasta até nossos dias, e que é o centro dos enfrentamentos entre os movimentos sociais (Reforma Agrária e Urbana) e aqueles detentores da terra. A terra no Brasil, a partir desta natureza engendrada, coloca o espaço em uma posição ainda mais estratégica para a reprodução capitalista e de manutenção da reprodução das relações de produção.

A produção do espaço de São Paulo vai carregando estas determinações específicas, e de obra se transforma em produto, conforme sua inserção na prática capitalista. A industrialização introduz uma ruptura no predomínio da produção do espaço como obra, e induz o processo de urbanização:

“... a não-cidade e a anti-cidade vão conquistar a cidade, penetrála, fazê-la explodir, e com isso estendê-la desmesuradamente, levando à

\footnotetext{
${ }^{14}$ Lefebvre, Henri, A re-produção das relações de produção, Publicações Escorpião, Porto, 1978, pp 20.

15 "Sendo a renda da terra de origem pré-capitalista, perde, no entanto, esse caráter à medida que é absorvida pelo processo do capital e se transforma em renda territorial capitalizada, introduzindo uma irracionalidade na reprodução do capital. A determinação histórica do capital não destrói a renda nem preserva o seu caráter pré-capitalista - transforma-a, incorporando-a, em renda capitalizada.”, Martins, José de Souza, O cativeiro da terra, Hucitec, São Paulo, 1998, pp. 03. Um outro momento que podemos destacar das implicações da formação capitalista brasileira é a nota 09 de Seabra (2003; 07) que faz a seguinte menção: “A urbanização é rentista porque a renda incrustou-se tão profundamente na reprodução social, envolvendo, com diferentes sentidos, capitais, grupos, indivíduos... que constitui um freio poderosíssimo à transformação social.”
} 
urbanização da sociedade, e ao tecido urbano recobrindo as remanescências da cidade anterior a indústria." 16

Da cidade industrial passa a uma cidade que se conforma como força produtiva a serviço da reprodução capitalista ${ }^{17}$, inserida nas redes das trocas, e que traz novas morfologias, e novas implicações entre os sujeitos e suas práticas sócio-espaciais. Dentre estas novas implicações tentamos desvendar por meio de nossa pesquisa, quais os novos conteúdos da urbanização que aprofundam a contradição uso-troca, enfocando o papel das instituições na vida dos habitantes da metrópole, no momento que a sociedade se realiza enquanto essencialmente urbana sob a égide capitalista. Trata-se, então, da produção socializada de riquezas e de espaços, que são apropriados privadamente, fato que revela o conteúdo da urbanização, aparecendo cada vez mais intensificada no processo de segregação sócio-espacial.

Esta segregação sócio-espacial revela, enquanto processo e expressão, pois se constitui materialmente, o espaço como objeto estratégico. Na produção espacial não há nada de neutro ou inocente, ela está permeada por toda ordem de intenções, porque o espaço é pressuposto de toda a vida, da produção, e portanto, ele totaliza os processos de produção e reprodução da sociedade imersa no capitalismo. Mas, o que lhe confere este status de estratégico? Como dito, ele se torna pressuposto de toda a reprodução da sociedade e totaliza as relações econômicas, políticas e sociais. Em uma sociedade capitalista que apresenta a fragmentação/separação - aspecto central da segregação como recurso estratégico de subordinação alicerçada na propriedade privada dos meios de produção, entre eles o espaço, ao fragmentar este mesmo espaço pela política e determinações econômicas, fragmenta os espaços de sociabilidade. Ao tender o espaço à homogeneização - tornar o espaço equivalente para o ato da troca - impõe um modo de vida que novamente empreende a implosão dos espaços-tempos da sociabilidade pautada no uso e na fruição. Ao hierarquizá-lo neste movimento do espaço estilhaçado

\footnotetext{
${ }^{16}$ Lefebvre, Henri, A Revolução Urbana, trad. Sérgio Martins, Editora UFMG, Belo Horizonte, 2002, pp. 25.

17 "É essa cidade, a cidade histórica como conceito, que era a cidade monacal como realidade histórica, porque circunscrita num espaço formado por mosteiros, que, a partir do último quartel do século XIX, sofrera os impactos e metamorfoses que a acumulação capitalista da sociedade, acabara por impor. Contudo, nenhum destes processos alcança a sociedade de uma só vez e em termos absolutos, porque todo e qualquer processo é espacialmente desigual e também porque é circunstancial no tempo.”pp 05, SEABRA, O.L., Urbanização e Fragmentação: Cotidiano e vida de bairro na metamorfose da cidade em metrópole, a partir das transformações do Bairro do Limão, tese de livre-docência, FFLCH-USP, São Paulo, 2003
} 
pela propriedade e homogeneizado pela lógica das equivalências, reúne os elementos separados escamoteando os laços de cisão.

Em uma sociedade na qual o desenvolvimento das forças produtivas se encaminha para um abismo ainda mais profundo entre riqueza produzida socialmente e apropriada privadamente denotando uma exploração mais intensa as tensões tendem a se agravar, à medida que avança a segregação das possibilidades de usufruir as conquistas materiais e de conhecimento da humanidade. $\mathrm{O}$ confronto entre desenvolvimento das forças produtivas e relações de produção se realiza ainda mais violentamente, e violentas também se tornam as formas de subordinação daqueles segregados, e assim, a centralidade e desafio do processo de acumulação e reprodução do capital está enfocando na manutenção das relações de produção. Nesta direção, o espaço transforma-se, na contemporaneidade, em estratégico, por comportar todos os planos da vida cotidiana (trabalho, lazer e vida privada) passíveis de serem normatizados e controlados por inúmeros mecanismos.

Assim, as condições de exploração e expropriação se atualizam, e as formas de dominação, que atingem aqueles expropriados das possibilidades de apropriação dos meios de produção para a realização do uso por meio da violência e coação, se camuflam sob os véus das ações assistencialistas e de caridade territorializadas por toda a extensão da metrópole.

A degradação da vida, o empobrecimento das relações sociais, de vizinhança, de uso se encontra neste movimento, isto é, na fragmentação e homogeneização do espaço, que possui na hierarquização uma forma de manter - pelo discurso do saber e da violência - as desigualdades.

As hierarquias do espaço representadas pelas centralidades na periferia carregam o conteúdo de sustentação das separações, dos fragmentos da vida social para que elas não explodam em transgressões e resistências à impossibilidade da apropriação do espaço para restaurar os espaços de sociabilidade. Elas reúnem a separação, gerenciam a segregação, unem na aparência o que na essência está dissociado, mas que não prescinde um do outro, já que ambos se realizam dialeticamente. O espaço, desse modo, aufere o conteúdo das relações de poder, penetrando as normatizações no vivido dos habitantes da metrópole para tentar dissipar as tensões latentes.

No bojo deste movimento é que a segregação sócio-espacial se realiza como produto, mas principalmente enquanto condição para a manutenção da reprodução das relações de produção. A segregação é mais do que a negação do acesso aos bens 
materiais, ela é o impedimento da apropriação do espaço para que a sociedade produza relações de solidariedade, isto é, a segregação é a negação do direito à cidade em seu sentido pleno.

\section{Apontamentos Sobre a Segregação Sócio-Espacial}

O espaço urbano vai se produzindo sob a forma de segregação e autosegregação. Dessa maneira, observamos na morfologia os grandes conglomerados de favelas que tendem a aumentar aceleradamente ${ }^{18}$, a abertura de um número considerável de loteamentos clandestinos com casas autoconstruídas, o envelhecimento de bairros da periferia onde os moradores se empobrecem e não conseguem realizar a manutenção de suas residências. Na perspectiva daqueles que concentram a renda produzida na metrópole, há a formação dos condomínios fechados, altamente equipados com as tecnologias de segurança, os prédios de alto luxo, que concebem um espaço adequado ao isolamento das famílias que neles residem. Mas, mesmo na busca pela separação, ambos os exemplos convivem juntos, em posições desiguais, tanto na vida quanto nos espaços da metrópole.

Este processo fundamenta-se numa tríade proposta por Lefebvre, que remonta as bases do espaço sob a lógica da mercadoria: é a fragmentação-homogenizaçãohierarquização do espaço. A tríade representa a lógica hegemônica da produção do espaço, produto e finalidade da reprodução do capital, na medida em que o espaço se incorpora ao mundo mercantil e se aprofunda atingindo a vida. A urbanização se realiza pautada nesta tríade destacadamente. É uma lógica que envolve as dimensões do econômico, político e social, transformando o espaço em instrumento que ora aufere rendas, ora se transforma em instrumento de poder político, e com isso, impede as ações de sociabilidade, e estes três momentos desta lógica atingem a vida dos habitantes.

Esta lógica se assenta nas equivalências, na equalização do desigual para tornar o espaço intercambiável, ou mesmo, para superar as "barreiras” que a prática sócioespacial impõe diante desta própria estratégia. Isto significa que ela não se realiza sem

\footnotetext{
${ }^{18}$ Enquanto a taxa de crescimento do município de São Paulo gira em torno de 0,88\%, o mesmo indicador do crescimento da população favelada é de 2,97\%, representando uma população de mais de 1 milhão de habitantes morando em habitações precárias (11,12\% do total de habitantes do município). Sumário de dados 2004, Município de São Paulo, Prefeitura Municipal de são Paulo, 2004. Em reportagem do jornal SPTV de junho de 2006, foi veiculada a notícia dos novos indicadores da Organização das Nações Unidas - ONU, indicando que nos próximos anos teremos uma população de 1,5 bilhão de favelados no mundo.
} 
conflitos, ou seja, pois estes são imanentes a este processo, de modo que as contradições aparecem.

A tríade fragmentação-homogenização-hierarquização do espaço compreendida enquanto lógica estratégia é vista como essencial para entender a centralidade do papel do espaço ${ }^{19}$ para a minimização das contradições do capitalismo.

O espaço mercadoria, dotado de potências de realização da reprodução do capital, se torna objeto de estratégias para manter as condições ideais de valorização do valor. Ele fragmenta-se pela propriedade privada mediado pelo equivalente dinheiro para acessá-lo, e homogeniza-se para se tornar isento de barreiras à reprodução do capital, bem como hierarquiza-se para dominar aquilo que ainda não está totalmente subordinado ou continuar a manter as condições necessárias de acumulação e reprodução.

Este processo lógico-estratégico implicaria no

“surgimento da não-cidade (ou anticidade; Lefebvre, 1991), na medida em que intensificaria a segregação sócio-espacial no urbano, criando obstáculos para o encontro e a reunião de pessoas, objetos de consumo coletivo, idéias, etc. Ou seja, na medida em que o valor de uso subordina-se ao valor de troca e a mercadoria generaliza-se no urbano, a cidade e a realidade urbana tendem a ser destruídas (Lefebvre; 1991), pois a cidade não é vivida em sua totalidade, e sim fragmentariamente e através de crescentes constrangimentos a seus habitantes. „20

Uma produção do espaço que também produz um tipo de homem, empobrecido do ato do uso, reduzido a mero consumidor, preso no mundo das “coisas", e dentre elas a cidade e a casa. Portanto, se o espaço é produzido logicamente como fragmentado, homogêneo e hierarquizado, a morfologia social, num processo dialético, em que cada qual está implicado no outro, se produz também com tais qualidades, e novamente, retomamos a desigualdade em que estamos mergulhados. Se as “coisas” se sobrepõe às relações entre os sujeitos no movimento desta tríade calcada na troca, ao vislumbrarmos

\footnotetext{
19 “O capitalismo apoderou-se do espaço inteiro. Sem o apropriar a seu uso, ele o domina e o modifica para a troca; ele produziu seu espaço, aquele de sua dominação, em torno dos centros de decisão, de riqueza, de saber e de infromação.”, Lefebvre, H. A respeito do Estado, tradução, Holanda, Baldraia e Pádua, pp.40.

${ }^{20}$ BOTELHO, Adriano, O financiamento e a financeirização do setor imobiliário: Uma análise da produção do espaço e da segregação sócio-espacial através do estudo do mercado da moradia na cidade de São Paulo, tese de doutorado, Faculdade de Filosofia, Letras e Ciências Humanas - Departamento de Geografia - USP, São Paulo, 2005.
} 
as implicações da produção do homem nesta sociedade, circunscrevemos a degradação da vida neste patamar, e que se aprofunda conforme o avanço da urbanização com bases capitalistas.

A periferia - se pensarmos o plano da metrópole - e a favela - se nos dirigirmos ao plano do privado, do lugar - não são meras morfologias precárias, elas comportam a produção de um homem que se submete às condições de perdas constantes. O homem que perdeu os referenciais desta própria metrópole, da dimensão de seu trabalho, e do habitar (sentido da apropriação) tornou-se estranho a este mundo que ele mesmo produziu.

O homem fragmenta sua vida cotidiana e se reduz a força de trabalho, isto é, a um “objeto” que é comprado e vendido, entrando na lógica da concorrência que corrói as relações com os demais sujeitos. Ainda reduzido à força de trabalho, traça um comportamento adequado às demandas deste próprio mercado para se reproduzir, e vai aos poucos perdendo suas particularidades e se homogenizando conforme os modelos pré-estabelecidos (normas) de consumidor, e por fim, as “coisas” que ele "tem” compõe a referência que o posiciona na hierarquia produzida pela divisão social e territorial do trabalho.

“Uma nova miséria se estende, que toca principalmente o proletariado sem poupar outras camadas e classes sociais: a miséria do habitat, a miséria do habitante submetido a uma quotidianeidade organizada..." 21

A conformação desta miséria se formava no padrão de periferias e centros, onde o primeiro termo se refere aos lugares da cidade em que se amontoam os elementos (pessoas e objetos) que representariam uma "barreira" ao processo de reprodução capitalista e que precisam ser controlados. Os centros são os “nós” de exercício do poder político e econômico, onde se produzem as estratégias para o enfrentamento das contradições da reprodução do capital. Segundo Lefebvre, a relação centro-periferia apareceria como uma contradição do espaço subordinada à fragmentação, na qual o espaço aparece como poder.

A segregação para além dos aspectos da precarização material da vida, seria, portanto, uma forma estrategicamente elaborada pelo saber e realizada na prática pelo poder político para dominar o espaço, e desse modo, ela tenta impedir as contestações,

\footnotetext{
${ }^{21}$ Lefebvre, Henri, Direito a Cidade,Editora Morales, São Paulo, 1991, pp.142.
} 
as ações organizadas da população, e por conseguinte, possui um caráter político que reforça a centralização exercida pelo centro de decisões.

As grandes periferias são necessárias para a manutenção da reprodução das relações de produção, pois nelas se realizam efetivamente a subordinação política dos habitantes da metrópole, na lógica da segregação sócio-espacial. A degradação da vida representa também a deterioração do homem político. E a favela não é somente expressão do homem espoliado, reduzido à mercadoria força de trabalho, mas é também a declaração material da redução das atividades políticas. A tendência é a expropriação do uso do tempo e do espaço para a produção dos espaços de socialização e das experiências de politização ${ }^{22}$ dos habitantes da periferia. Contudo, cabe uma questão importante: qual a mediação entre a ordem distante (a do centro de decisão) e dos lugares existentes na periferia? Tal mediação seria a metrópole com suas centralidades na periferia, porém, o que leva a cabo estas relações de poder internamente às centralidades?

\section{Uma Leitura Possível da Dominação e da Apropriação do Espaço}

A leitura de Damiani sobre a produção do espaço urbano nos permite pensar o movimento de reprodução da metrópole hoje, a partir da idéia de urbanização crítica, isto é, “a urbanização como um novo setor produtivo e como estratégia política à considerar"23, já que ela é usufruída pela mediação do dinheiro. Isto significa compreender que a urbanização é vista pelo viés de sua rentabilidade, como um setor produtivo profícuo para a reprodução do capital, trazendo como conseqüência a impossibilidade de fruição do urbano (como reunião e simultaneidade de pessoas e ações).

A urbanização, à medida que avança, mobiliza o que está a sua frente para realizar-se como negócio e ela pode mobilizar também as relações sociais préexistentes, e neste percurso ao transformá-las, as potencializa para a reprodução capitalista. Ela tenta mobilizar os espaços, e mesmo a propriedade, que entram no tempo

\footnotetext{
22 "Embora as pessoas encontrem, de saída, numa sociedade estruturada já de determinada maneira, a constituição histórica das classes depende da experiência das condições dadas, o que implica tratar tais condições no quadro das significações culturais que as impregnam. E é na elaboração dessas experiências que se identificam interesses, constituindo-se então coletividades políticas, sujeitos coletivos, movimento sociais.”, Sader, Eder, Quando novos personagens entraram em cena, São Paulo, 1988, pp 45.

${ }^{23}$ Damiani, Amélia Luisa, A crise da cidade: os termos da urbanização, In:Carlos, A. F. A., Damiani, A., Seabra, O. L. S., O espaço no fim do século: a nova raridade, Geousp Abordagens, Contexto, São Paulo, 1999.
} 
da produtividade e assumem funções que varrem as possibilidades de uso. Esta busca de mobilização se realiza num tempo espaço desigual, redefinindo as funções de cada lugar da metrópole.

Em relação à periferia, esta se produz por determinações econômicas, políticas e sociais como o lugar do confinamento daqueles impedidos de usufruir do urbano, ou que apenas se aproximam dele precariamente. É uma situação politicamente necessária para a realização dos “negócios do urbano” amplamente. Por isso, Lefebvre nos aponta que

“A contradição principal se desloca e se situa no interior do fenômeno urbano: entre a centralidade do poder e as outras formas de centralidade, entre o centro 'riqueza-poder' $e$ as periferias, entre a integração e a segregação" 24

À medida que os negócios avançam na metrópole, há incorporação de uma massa crescente de terrenos, integrando partes da periferia, que até então eram vistas somente como o lugar onde residiam aqueles que deviam ser dominados. Esta integração ao setor produtivo redefine centralidades e a própria noção de periferia, e a redefine, além disso, as políticas públicas empreendidas pelo Estado, como também, as ações de setores como as organizações não governamentais que realizam funções, que antes do desmonte neoliberal, eram atribuição estatal.

À medida que o espaço se hierarquiza entre periferias e centros de decisão, as estratégias se generalizam, comportando a finalidade de transformar o espaço num negócio “em si”, ou seja, potente para a acumulação. Desse modo, levando às últimas conseqüências as implicações da tendência da sobreposição do valor-de-troca sobre o valor-de-uso e mesmo, para realizar a lógica estratégica, chegamos a uma contradição importante na pesquisa, e que Damiani aponta como um dos elementos da urbanização crítica, a contradição entre a apropriação e dominação do espaço ${ }^{25}$.

Damiani sinaliza que estas transformações da urbanização regida pela lógica do capital empreendem um avanço na crise da apropriação da cidade, indicando novas

\footnotetext{
${ }^{24}$ LEFEBVRE, Henri, A Revolução Urbana, trad. Sérgio Martins, Editora UFMG, Belo Horizonte, 2002, pp 155.

${ }^{25}$ Seabra já sinaliza a questão da apropriação e propriedade expondo como as relações quantitativas, fundamento da relação de troca implica na impossibilidade do uso e da apropriação. “... a apropriação está referenciada a qualidades, atributos, ao passo que a propriedade está referenciada a quantidades, as comparações quantitativas, igualações formais, ao dinheiro (que delimitando o uso tende a restringi-lo).”, Insurreição do Uso, In: Henri Lefebvre e o retorno à dialética, MARTINS, J. S.(org.), Hucitec, São Paulo, 1996, pp 71.
} 
formas de alienação e seu aprofundamento, entendidas como perda dos significados sociais da produção da cidade.

“Domínio do espaço e apropriação do espaço não são sinônimos, mas, em nossa época, definem uma contradição fundamental. Talvez, ainda mais, a deterioração dos dois termos dessa contradição. Domínio, sugerindo devastação; apropriação, definindo empobrecimento das relações sociais. ${ }^{26}$

Outra análise que permite situar também a problemática é a de Carlos, na qual a autora assinala a cisão entre a apropriação e a dominação levando-os a se tornarem termos em conflito no mundo moderno,

“Mas a apropriação e dominação se separam no mundo moderno, entram em conflito; a dominação ganha conteúdo das estratégias políticas que produzem o espaço da coação, posto que normatizado pela ordem que se impõe a toda a sociedade, direcionando a prática espacial, á medida que a apropriação se realiza enquanto prática criativa em luta contra a norma." 27

A dominação do espaço, central para a realização dos negócios do urbano, é consumada numa prática estratégica, que se define também por uma prática política, impondo regras de convivência, normatizações das condutas dos sujeitos na metrópole nos mais simples atos do vivido.

Num outro plano, o da contradição uso-troca, as possibilidades de apropriação se reduzem frente a territorialização das normas. A propriedade realizando o ato da troca impede o morador de viver a cidade conforme seus costumes, de maneira espontânea, principalmente, por este habitante se produzir enquanto alguém que não possui direitos, já que seu poder aquisitivo não o considera como cidadão (redução da idéia de cidadania pautada no consumo e não nos princípios do uso). A prática da concorrência imposta aos habitantes como necessária para se tornar cidadão, corrói, internamente, as relações dos indivíduos em sua vida cotidiana. As relações de solidariedade vão se rompendo para levar a cabo a reprodução das relações de produção “ideais”. Assim, a dominação do espaço reduz as práticas cotidianas de apropriação para a realização da

\footnotetext{
${ }^{26}$ Damiani, Amélia Luisa, A crise da cidade: os termos da urbanização, In:Carlos, A. F. A., Damiani, A., Seabra, O. L. S., O espaço no fim do século: a nova raridade, Geousp Abordagens, Contexto, São Paulo, 1999, pp.126

${ }^{27}$ Carlos, Ana Fani Alessandri, Sobre Planos e Níveis de Análise, In: O Espaço Urbano: Novos escritos sobre a cidade, Contexto, São Paulo, 2004.
} 
vida, culminando em um empobrecimento da vida social e política dos habitantes, pois regidos por normas de uma ordem distante (de instituições e do Estado), e não elaboradas pelo que funda os costumes, o que ratifica a dominação.

Damiani, então, situa a questão dominação/apropriação, e nos encaminha para a análise das lógicas empreendidas no lugar, primeiro momento a ser refletido sobre a realidade. Este momento prévio e necessário, antes de nossa inserção nas possibilidades de insurgências, pelas transgressões na vida cotidiana de seus habitantes, na produção do lugar, já que apropriação existe como condição necessária à vida.

Assim, de acordo com Damiani,

“Configura-se um conflito e uma diferença: há espaços dominados e espaços apropriados. A vida contraditória e diferenciada, apesar de toda a 'lógica', imprevista, invade e perturba a racionalidade redutora imposta. Nesse momento, mesmo que residualmente apropriação.

É preciso desvendar o espacial, que caracteriza este fim de século, como lógico, uma sócio-lógica, a lógica traduzida por estratégia real, se realizando no terreno. A essência do espacial, como se caracteriza neste momento, é a lógica, mais ainda, a lógica formal. Ela alimenta o planejamento, a informação, a deterioração da dialética do tempo. E somente um pensamento que localize essa lógica, e a transcenda, revela a dialética do espaço."28

A mediação das estratégias de dominação se realizam de várias formas, dentre elas, as das centralidades erigidas na periferia, que comportam sujeitos legitimados pela legalidade, pela representação do Estado, ou então, através dos discursos e representações internas aos lugares da metrópole. Estes sujeitos introduzem relações de poder nos lugares da periferia, empreendendo a sua territorialização.

O sentido da noção de territorialização é apreendida pelas contribuições de Raffestin. Ele situa a territorialização de sujeitos no espaço, dando ênfase nas relações de poder, que são essenciais numa realidade calcada na troca. "Ao se apropriar de um espaço, concreta ou abstratamente (por exemplo, pela representação), o ator 'territorializa' o espaço” ${ }^{29}$. São estas relações de poder que destacamos na pesquisa, no sentido de considerar o nível político como fundamental para o desvendamento da

${ }^{28}$ DAMIANI, Amélia, A crise da cidade: os termos da urbanização, In:Carlos, A. F. A., Daminai, A., Seabra, O. L. S., O espaço no fim do século: a nova raridade, Geousp Abordagens, Contexto, São Paulo, 1999, pp54.

${ }^{29}$ Raffestin, Claude, Por uma geografia do poder, Atica, São Paulo, 1993. 
problemática que está sendo desenvolvida. O sentido das noções de território e de territorialização é apreendido enquanto possibilidade de elevar à análise as mudanças de relações de poder, que têm no espaço papel fundamental para a realização da reprodução da sociedade. O espaço é antes de mais nada espaço político, pois é objeto e ao mesmo tempo instrumento, das estratégias e planos dos sujeitos implicados na produção dos lugares na metrópole. Este destaque não significa autonomizar o plano político dos demais, ao contrário, pretende enfocar as implicações deste plano em relação aos outros, e a ênfase nas relações de poder nos permite exprimir o sentido da cisão entre domínio e apropriação do espaço. É neste aspecto, que nos afastamos da argumentação do autor, por ele considerar o espaço enquanto um fator a priori, e não como condição, meio e produto da reprodução da sociedade.

Em um processo profundo de fragmentação do espaço, as relações de poder se tornam cada vez mais relevantes na luta dos sujeitos pela possibilidade de domínio e apropriação do espaço, pois dele resultam as possibilidades de uso e de manutenção da reprodução das relações de produção.

Geralmente, os portadores da legitimidade são aqueles muito próximos da dimensão do vivido, do lugar, e se territorializam por esta condição, mas que soma o peso da institucionalização em uma realidade que a representação atrelada ao Estado se torna fundamental em termos de garantia de realização dos serviços. São, portanto, instituições como a Igreja, as associações de bairro ou então, principalmente a partir da década de 90, as organizações não governamentais. Estas instituições possuem projetos específicos, visões sobre a realidade e ações que tentam concretizar os projetos, contudo, pautados pela legitimidade estatal submetem-se às normas deste centro de poder e decisão, seja pelos mecanismos próprios das relações de poder ou então, pelo aspecto econômico.

A territorialização de sujeitos e instituições, que muitas vezes produzem uma centralidade, como neste estudo, ganha o sentido desta dominação, na medida em que concretiza as normas no lugar. Estas normas possuem níveis, isto é, as das instituições locais com seus projetos, que muitas vezes se chocam com as normas do Estado (instituição central). Esta realidade representa, ao focarmos os sujeitos da produção das estratégias de dominação do espaço, uma produção que não se realiza sem conflitos com os sujeitos emissores de tais normas. Há níveis que precisam ser considerados e, por isso, a construção das normas e suas imposições para a dominação devem ser 
concebidas como um processo contraditório. É o choque da prática das territorializações.

Na presente pesquisa o acento está nas relações entre uma organização não governamental e os moradores da Favela Monte Azul. A Associação Comunitária Monte Azul é precursora das organizações não governamentais por constituir-se deste o fim da década de 70 no formato exigido atualmente para instituições desta natureza. Atualmente, é um exemplo para o denominado “terceiro setor” nas áreas de educação e saúde. Em relação à metrópole, a atuação de destaque são as atividades culturais, que atribui a visibilidade aos demais trabalhos realizados.

A partir da década de 90, este tipo de organização adquire legitimidade pelas políticas de ajustamento estrutural dadas pela conjuntura neoliberal, que na lógica do Estado mínimo repassa funções ditas “sociais” para instituições, destacadamente as organizações não governamentais. Na argumentação de Chossudovsky, que discute os impactos das reformas do FMI (Fundo Monetário Internacional) e do Banco Mundial, este autor situa o papel das ONGs na manutenção das tensões sociais mostrando que

“O FSE (fundo social de emergência) exige uma abordagem de 'engenharia social', um esquema político para 'administrar a pobreza' $e$ aliviar a inquietação social a um custo mínimo para os credores. Os chamados 'programas com metas estabelecidas' destinados a 'ajudar os pobres', combinados com a 'recuperação do custo' e a 'privatização' dos serviços de saúde e educação, são considerados um meio 'mais eficiente' de liberar programas sociais. O Estado retira-se e muitos programas sob a jurisdição de ministérios alinhados serão, daí em diante, administrados por organizações da sociedade civil sob o patrocínio do FSE. Este também financia, sob os auspícios da 'rede de seguridade social', pagamentos de indenização por demissão e/ou projetos de 'mínimo emprego' destinados aos funcionários públicos demitidos em conseqüencia do programa de ajuste.

O FSE sanciona oficialmente a retirada do Estado dos setores sociais e a 'administração da pobreza' (no âmbito microssocial) por meio de estruturas organizacionais separadas e paralelas. Várias organizações não governamentais (ongs) financiadas por 'programas de ajuda' internacionais têm absorvido gradualmente muitas das funções do governo de cada país. (...) Assegura-se, desse modo, uma precária sobrevivência 
para as comunidades locais, ao mesmo tempo em que se diminui o risco de sublevação social." 30

Portanto, estas organizações não governamentais legitimadas através das condições dadas conjunturalmente, se espalham por toda a periferia realizando as tarefas “sociais” e muitas vezes, tornam-se as bases das ações dos sujeitos territorializados nas centralidades constituídas. A territorialização é mantida por meio da gestão dos serviços, que na maioria dos casos não possui mecanismos participativos da população local, mas, realiza o projeto da própria organização, mesmo que este também esteja submetidos as normas do Estado. Contudo, o alicerce deste tipo de gestão está na propriedade privada dos prédios e apartamentos onde se concretizam as ações.

São estas ações que dão os conteúdos desta centralidade, funcionalizando-as para introduzir a lógica de um cotidiano programado. No caso da Associação Comunitária Monte Azul e da Favela Monte Azul, que nas relações tecidas ao longo das décadas transformam o lugar em uma centralidade na periferia, ao atrair fluxos de pessoas, estrangeiros, pesquisadores, capitais e políticas públicas, observamos as normatizações como termo regulatório para minimizar os conflitos e tentar impedir uma participação popular fora dos marcos do assistencialismo.

O conteúdo desta centralidade, lida através das ações que esta associação empreende, está pautada nos níveis essenciais da vida e da formação do indivíduo, como a educação. Desse modo, a vida cotidiana se torna objeto importante de crítica, e compreendê-la significa desmistificar as estratégias que são postas aos habitantes da metrópole em sua formação como indivíduos. Estas estratégias impõem um novo modo de vida que está calcado no consumo, com orientação conservadora, e vão aos poucos reduzindo o ato da apropriação.

Entretanto, estas territorializações não se impõem passivamente, mas estão em constante embate com os demais sujeitos que vivem no lugar e o produzem com seu espaço-tempo específico. É neste sentido que as transgressões surgem e elas podem ao mesmo tempo ratificar as ações de empobrecimento das relações sociais, ou então, questionar as formas do assistencialismo. Isto significa que os sujeitos implicados estão agindo, portanto, ativos no processo, seja para questionar, seja para ratificar, ou como diz Martins “... a alienação não é um processo passivo, mas sim um processo social

\footnotetext{
30 Chossudovsky, Michel, A globalização da pobreza: Impactos das reformas do FMI e do Banco Mundial, Moderna, São Paulo, 1999, pp 58/59.
} 
ativo. Nele, o sujeito ativa e criativamente desenvolve mecanismos compensatórios para as privações que o alcançam.” 31

Na produção deste lugar, imerso nas alienações e coações, o indivíduo produz também uma maneira de negação através das transgressões, que podem levar a um aprofundamento da dominação do espaço. Ou seja, a territorialização da Associação começa a ser questionada cedendo lugar para as ações da violência urbana, pois o lugar ao se transformar numa centralidade na periferia, reúne as condições para a realização do negócio do tráfico de drogas, que até então não existia na favela pela própria presença desta outra territorialização. Estes novos "negócios” transformam-se na alternativa para os jovens que não se incorporaram aos projetos da Associação, e denotam um quadro ainda mais perverso da urbanização. Isto é,

“No limite, podem usar meios ilícitos para obter os recursos de que necessitam para integrar-se: o tráfico, o roubo, a violência, os meios transgressivos de participação. A deterioração dos valores éticos que deveriam permear as relações sociais, e que daí resulta, já produz seus desastrosos efeitos na socialização anômica das novas gerações, na vivência cotidiana atravessada pela violência." ${ }^{32}$

A construção do desenvolvimento da problemática da degradação da vida e as formas de insurgências está atravessada por estas questões. Em nosso objeto específico, a territorialização da Associação Comunitária Monte Azul e suas implicações na produção do lugar enquanto uma centralidade na periferia, percebemos as contradições decorrentes do desenvolvimento de tais relações construídas. Tal processo de territorialização, com o espraiamento das normas elaboradas pela ONG, implica na dissolução da identidade concreta dos moradores e edificação da identidade abstrata pelos mecanismos burocráticos próprios das instituições, legitimando o impedimento das ações de apropriação do espaço que dão a qualidade ao direito à cidade.

\footnotetext{
${ }^{31}$ Martins, José de Souza, A sociedade vista do abismo: novos estudos sobre exclusão, pobreza e classes sociais, Ed. Vozes, Petrópolis, 2003, pp. 44.

${ }^{32}$ Idem, pp 39.
} 


\title{
Capítulo III
}

\section{A Territorialização da Associação Comunitária Monte Azul}

\begin{abstract}
"A perda da cidade reaparece como tema, mas não necessariamente atrelada à pobreza material, à pobreza absoluta, na figura da ausência de serviços e equipamentos urbanos. Aparece, em última instância, como perda de fluidez da vida urbana, como perda da vida urbana propriamente, e de suas possibilidades. A deterioração da vida urbana não seria fundamentalmente função do crescimento das cidades, identificado ao crescimento de problemas e carências materiais estritas."
\end{abstract}

Amélia Damiani $^{1}$

Um mosaico de instituições estão presentes na periferia de São Paulo, dentre elas as organizações não governamentais, que a partir da década de 90 se alastraram por todo o município, realizando ações nos setores ditos sociais, ou seja, atrelados à educação, saúde e cultura principalmente. Este processo decorre do fato de ter havido uma renovada estruturação do Estado, conforme sua inserção no ajuste estrutural exigido pelas políticas neoliberais. O cerne destas políticas está na isenção do Estado frente às demandas sociais, reduzindo verbas das áreas essenciais como saúde e educação,o que levou a uma privatização destas áreas, uma vez que a demanda foi repassada para a iniciativa privada.

A redução de verbas (de acordo com a lógica do enxugamento do Estado) ocasionou uma dupla conseqüência, a partir da incorporação, via contrato, de organizações terceirizadas do tipo ONGs para a execução destes serviços. O resultado duplo é tanto uma precarização do trabalho para aqueles que são contratados, quanto uma precarização dos serviços prestados a grande maioria da população urbana.

Algumas questões se colocam após esta afirmação. As organizações não governamentais estão explicitamente de acordo com estas precarizações? E quanto aos habitantes da metrópole, estão aceitando passivamente a introdução destes novos sujeitos que entram em cena principalmente a partir da década de 90? Será que o entrelaçamento entre Estado/empresas privadas, Ongs e moradores nos revela um conteúdo relevante do processo de urbanização, isto é, as estratégias de subordinação e suas formas para a reprodução das relações de produção no espaço urbano, porque é

\footnotetext{
${ }^{1}$ Damiani, Amélia, A cidade (des)ordenada: Concepção e Cotidiano do conjunto habitacional Itaquera I, FFLCH/DG, São Paulo, 1993, 14.
} 
nele que se encontram as maiores perdas do homem? O que pretendemos neste trabalho não é esgotar tais questões, mas colocá-las em relevo na medida que descortinamos o papel da Associação Comunitária Monte Azul na produção de um lugar na periferia de São Paulo. Buscaremos também, compreender em que medida o processo de sua construção e as ações das quais se valem estas instituições, são contraditórias, bem como, se implicam em uma totalidade da metrópole.

A idéia que alicerça o desenvolvimento deste capítulo é a compreensão de que estas Ongs, como uma das formas institucionais que se encontram na periferia de São Paulo, se legitimam pela escassez à qual a periferia é relegada, territorializando-se na metrópole, e realizando a precarização no duplo sentido. Porém, cada instituição comporta um projeto, que pode ser desde pleitear a organização autônoma da população até realizar obras com fins de caridade. Mas, a contradição reside no fato de que o ato do contrato, no qual as ONGs se submetem às normas do Estado ou das empresas privadas (quando estas são as mantenedoras), as subordinam. Tal subordinação compromete largamente o projeto proposto, pois a violência da troca, que pressupõe as relações de poder, transparece, prevalecendo as determinações da ordem distante. E uma vez que as ONGs se territorializam nos lugares para concretizar seus projetos, está implícita a subordinação, e esta condição acaba sendo imposta a um segundo grau à população atendida. Desse modo, ambos os sujeitos - instituições e moradores - estão presos a amarras à ordem distante, e neste embate, reivindicam, de modos distintos, a autonomia.

Assim, as transgressões dos sujeitos são compreendidas enquanto parte do processo, que nega, em diferentes intensidades, a opressão e a repressão da ordem distante, para que eles possam realizar, ainda que precariamente, os projetos, fruto das experiências provenientes de sua história particular. O que é imprescindível aclarar é o modo pelo qual cada sujeito está submetido às amarras, quais as relações de poder que lhes permitem conduzir os projetos conforme seus desejos, e como disto resulta, ao mesmo tempo, a manutenção de relações e o questionamentos delas.

Trata-se, então, de buscar a compreensão da territorialização da ACMA por meio dos conflitos na produção do lugar enquanto centralidade na periferia, bem como, as ações em dois processos específicos - a “urbanização da favela” e a atividade teatral - que nos lançam sobre as degradações da vida na produção do espaço urbano. 
O tema Organização Não Governamental transformou parte das pesquisas relacionadas à participação popular e as ações coletivas, como também às estratégias de grupos de esquerda. Esta instituição surge no Brasil como uma resposta ao regime autoritário vigente na década de 70 e a partir da redemocratização ganha centralidade no país.

Segundo Doimo, “a origem das ONGs está diretamente relacionada à intervenção autoritária do regime militar nas principais universidades brasileiras, obrigando renomados intelectuais a desenvolverem sua atividade fora dos espaços mantidos pelo Estado. A criação do CEBRAP e, posteriormente, do CEDEC são os maiores exemplos desse imperativos conjuntural, o que curiosamente, coincidirá com necessidades estruturais da Igreja Católica, de convívio amistoso com as Ciências Humanas, com vistas a incorporar certo saber técnico-competente para melhor interação com o mundo moderno. (...) Essa experiência de deslocamento da produção científica das universidades para as ONGs cresceu muito durante a década de 80, sob a justificativa de 'colocar o conhecimento especializado a serviço dos movimentos populares"” $164^{2}$

A nova condição posta pela conjuntura política e econômica nas décadas de 70/80, fixa parâmetros de participação calcados na institucionalidade, franqueando uma brecha para as recentes inserções políticas, que por um lado, leva ao enfraquecimento e dissolução das práticas dos movimentos sociais e por outro, licencia a presença de organizações institucionais, que farão o diálogo com o Estado.

As experiências balizadas por ações diretas, vão cedendo terreno a representatividade, que está marcada pelos elementos das políticas clientelistas e assistencialistas. Para Sader (1988), em relação aos movimentos sociais, estes “foram projetados para enfrentamentos decisivos quando ainda mal se haviam constituído como sujeitos políticos. O ritmo de suas histórias não era o mesmo que o da política instituída, e foi esta que fixou as datas. Levadas 'precocemente' aos embates políticos, expressaram sua

\footnotetext{
${ }^{2}$ Doimo, Ana Maria, A Vez e a Voz do Popular: Movimentos sociais e participação política no Brasil pós-70, Relume Dumará, Rio de Janeiro.
} 
imaturidade enquanto alternativas de poder no plano da representação política.” (p.315)

A institucionalização vai substituindo as formas relativamente autônomas de organização da população, como foram os movimentos sociais. Uma nova era das organizações se estabelece e

“As ONGs deixam de ser meros apoios e passam a ter centralidade, pois a nova era irá exigir novas relações sociais entre Estado e a sociedade civil. Os movimentos sociais em geral, e os populares em particular devido às divergências político-ideológicas - , não estavam preparados para esta nova era. As ONGs assumem a liderança de vários processos sociais.” (p.57)

“Nos anos 90, o que era ocasional se institucionaliza e os atores sociais privilegiados, convocados a ser parceiros das novas ações, são os tradicionais aliados do poder. O movimento social mais combativo, que se encontra fragilizado e fragmentado por sua crise de identidade, disputas internas etc. não tem nenhuma garantia de participação nas novas políticas porque ele tem uma formatação que não é condizente com as exigências das políticas de parceria, e fora das políticas públicas não há recursos financeiros porque os financiamentos internacionais escassearam. ${ }^{\text {,3 }}$ (p.32)

Desse modo, as organizações não governamentais se espalham por todos os cantos da vida pública, e incorporam a representação das lutas urbanas, transformandose em mediação entre população e Estado.

Cabe aqui uma nota importante. No período de eclosão dos movimentos sociais urbanos, os espaços de sociabilidade produzidos a partir de grupos que atuavam na periferia (Igreja Católica e organizações de esquerda, destacadamente) versavam sobre as carências da população e tentavam construir formas de luta diretas com os que sofriam tais mazelas. A relação direta possibilitava a apropriação do processo de luta em sua totalidade, fazendo os sujeitos descobrirem seus interlocutores através da prática.

Este processo, que podia resultar na produção de um espaço de experiências de politização, não significava em parte a negação da tendência capitalista de inserção na lógica da troca, pode sim, colocar em relevo as contradições da sociedade.

\footnotetext{
${ }^{3}$ Gohn, Maria da Glória, Os sem-terra, ONGs e cidadania, Cortez Editora, São Paulo, 1997.
} 
A oportunidade de, na prática direta e não institucionalizada, deparar-se com as contradições deste modo de produção pôde ser ampliada, porque não se amarravam ao espaço-tempo das instituições que levam a cabo a reprodução das relações de produção. Não transformava as relações em mera abstração dada pelas relações políticas, antes de tudo, se vivia a política, isto é, as relações políticas se subordinavam de certo modo às relações sociais.

Percebemos que a questão que se coloca, portanto, não é apenas uma dualidade de relações diretas e indiretas, ou movimentos sociais e instituições, e sim, a compreensão das possibilidades de apropriação de um determinado processo, dada a natureza dos sujeitos implicados. Os movimentos sociais não pactuados com o Estado capitalista colocavam com maior potência as possibilidades de questionamento da tendência hegemônica, enquanto as instituições, atreladas ao desenho burocrático - com acento na abstração das relações pela representação- reduzem, retardam, ou mesmo, impossibilitam a construção de um processo que dê conta do fundamento da exploração, expropriação e espoliação do homem.

Assim, tanto os movimentos sociais quanto as organizações não governamentais são apreendidos dentro de uma perspectiva em que ambos nos colocam diante das contradições, contendo limites e possibilidades para a reprodução da sociedade. Coube ao pesquisador, já delimitado pela problemática, refletir sobre os significados das práticas destes sujeitos dentro de uma matriz de projeto de mundo.

É desta maneira, que lemos as ONGs enquanto uma forma renovada de luta pelo acesso aos serviços e, mesmo a propriedade do solo urbano, mas que carrega a subordinação a um Estado capitalista, já que se vê atrelada pelas normas jurídicas, e destacadamente, econômicas.

No que se refere as ONGs, sabemos que grande parte realiza trabalhos nas favelas de São Paulo, consideradas como os lugares com maior índice de precarização dos serviços. E através dos serviços constroem centralidades do terceiro setor (termo dado ao setor das ONGs). Um bom exemplo são as ações na Favela Paraisópolis, localizada em um bairro de alto poder aquisitivo - o Morumbi - e próximo da Favela Monte Azul. Ela é a segunda maior favela do município de São Paulo e é objeto da ação de várias entidades, dentre elas as ONGs.

"Há diversas entidades que, contando com financiamento público, beneficiam a população local com cursos de marcenaria, jardinagem, inglês, e sobretudo, informática. A contrapartida da favela em relação aos 
projetos assistencialistas providos pelo entorno rico é sanar aquele que do ponto de vista das classes privilegiadas é o maior problema dos lugares pobres: a violência." 4

Este objetivo geral das ações das entidades locais expressam a visão de caridade e perpetuação das relações assistencialistas e de dependência. Este exemplo ainda aborda os financiamentos oriundos daqueles que residem no entorno, embora, não sejam os únicos. A cadeia de financiamentos provém também de uma lógica internacional, em que entram a aprovação pelos marcos do Banco Mundial e do Fundo Monetário Internacional em ações que vão desde a educação até “urbanização de favelas”.

Davis (2006; 84-87), ao abordar a questão das ONGs nos países ditos de Terceiro Mundo, nos encaminha para a reflexão sobre as ações destas instituições que se territorializam na periferia paulistana:

“Na verdade, a revolução das ONGs - há hoje dezenas de milhares delas nas cidades do Terceiro Mundo - reconfigurou a paisagem do auxílio ao desenvolvimento urbano praticamente do mesmo modo que a Guerra à Pobreza da década de 1960 transformou as relações entre Washington, as máquinas políticas das cidades grandes e os eleitorados rebeldes dos bairros pobres. Enquanto o papel do Estado como intermediário reduzia-se, as grandes instituições internacionais instauraram a sua própria presença na base por meio de ONGs dependentes em milhares de favelas $e$ comunidades urbanas pobres. Tipicamente, um doador-financiador internacional - como o Banco Mundial, o Departamento de Desenvolvimento Internacional do Reino Unido, a Fundação Ford ou a Fundação Friedrich Ebert alemã - trabalha por meio de uma ONG importante, que por sua vez dá consultoria a uma ONG local ou destinatário nativo. Esse sistema de coordenação e financiamento em camadas costuma ser retratado como a última palavra em empowerment, 'sinergia' e 'governança participativa'."

“Apesar de toda a retórica retumbante sobre democratização, construção por conta própria, capital social e fortalecimento da sociedade civil, as verdadeiras relações de poder nesse novo universo das ONGs são parecidíssimas com o clientelismo tradicional. Além disso, como as

\footnotetext{
${ }^{4}$ Almeida, R. e D’Andrea, T. , Estrutura de Oportunidades em uma favela de São Paulo, In: São Paulo: Segregação, pobreza e desigualdades sociais, Senac, São Paulo, pp 2032005.
} 
organizações comunitárias patrocinadas pela Guerra à Pobreza da década de 1960, as ONGs do Terceiro Mundo mostraram-se brilhantes na cooptação dos líderes locais assim como na conquista da hegemonia do espaço social tradicionalmente ocupado pela esquerda. Ainda que haja algumas louváveis exceções - como as ONGs combativas tão úteis na criação dos Fóruns Sociais Mundiais -, o maior impacto da 'revolução das ONGs/da sociedade civil', como admitem até mesmo alguns pesquisadores do Banco Mundial, foi burocratizar e desradicalizar os movimentos sociais urbanos".(p.85)

"As ONGs, observa a ativista e escritora Arundhati Roy, 'acabam funcionando como o apito de uma panela de pressão. Desviam e sublimam a raiva política e garantem que ela não chegará ao ponto de explodir'”.(p.87)

No Brasil, tais afirmações podem ser incorporadas como partes constituintes das complexas intervenções do Estado sobre os vários lugares da metrópole, reforçando as características clientelistas/assistencialistas presentes na periferia paulistana. Gohn (1997) assinala dois aspectos das ONGs que nos auxiliam na compreensão de como elas integram a engrenagem de desmobilização

"O primeiro, de caráter mais político, criará espaço institucional às ONGs à medida que grupos de esquerda, nas suas diferentes matrizes, ascendem ao poder. As ONGs passarão a ser pontos básicos de suporte técnico-político às novas administrações. O segundo, de caráter mais econômico, estruturará paulatinamente uma rede de instituições, caracterizadas como comunitárias, as quais ganharão paulatinamente uma maior confiabilidade no gerenciamento de recursos e na eficiência de suas ações, em relação às entidades de caráter público propriamente ditas" (p.60).

É nesta fase que a legitimidade destas instituições, que de certa forma representavam a população, ganha mais força, e a possibilidade de se territorializar efetiva-se, tornando a mediação entre as lutas dos moradores frente ao Estado. Mas, na medida em que conquistam tal característica, a luta direta se esvazia, bem como, as possibilidades de atuação mais contundentes de questionamento das ações que 
conduzem a produção do espaço urbano tendente à sobreposição do valor-de-troca sobre o valor-de-uso.

Internamente aos locais de atuação, legitimam-se pela possibilidade de erradicar a privação das quais os moradores estão submetidos. Contudo, a manutenção destas relações se realiza por dois elementos essenciais, que ratificam a segregação sócioespacial enquanto condição de reprodução das relações de produção. São eles a propriedade privada dos equipamentos e a gestão não participativa, que estão diretamente implicadas na normatização dos usos do espaço urbano.

Em relação à territorialização da Associação Comunitária Monte Azul (ACMA), a sua particularidade produziu um lugar com diferenciações claras, mas não escapa do ordenamento geral ao qual as organizações não governamentais se submetem, ao mesmo tempo em que subordinam os moradores. No bojo do processo descrito, pretendemos desenvolver as implicações na produção do lugar na periferia em seus três níveis sob o olhar nas ações desta ONG e ao desenvolvê-los vamos tecendo as linhas do conflito e das contradições que estão no cerne da problemática.

Podemos, em resumo, destacar algumas destas implicações da territorialização da ACMA na Favela Monte Azul e que desenvolveremos mais adiante:

1) Plano Econômico: precarização do trabalho e serviços, movimentação de capitais - inclusive internacionais - pelos Estados e empresas privadas via ONGs (determinações internacionais FMI e Banco Mundial - “recuperação de custos”), concentração de fluxos de capitais, produção de mão-de-obra - principalmente para atender às empresas de serviços - , introdução dos moradores à lógica do consumo, valorização do solo urbano. Estes efeitos são produtos das estratégias do processo de acumulação, que possui o espaço como condição e meio de sua realização, conforme elimina as "barreiras” e produz o espaço de modo a inseri-lo no processo produtivo;

2) Plano Político: manutenção das relações assistencialistas e de dependência, subordinação tanto da ACMA como dos moradores da favela à ordem distante, do Estado - ou os mantenedores (empresas privadas)- , não participação dos moradores nas decisões das ações que regem os serviços oferecidos no lugar de morada, manutenção da reprodução das relações de produção pelas relações de poder impressas no espaço, bem como, a transformação do espaço em instrumento de poder. Novamente, o espaço aparece em sua dissimulação no nível do político, pois a ideologia produzida pelas melhorias infra-estruturais e as relações internas tecidas, faz crer que se trata de um lugar na metrópole “livre” e “transparente”. Esta condição atribuída ao espaço é 
fundamental para que ele mesmo seja produzido sob os marcos necessários à acumulação capitalista;

3) Plano Social: ocorrem melhorias na infra-estrutura e de serviços - mas nem todos possuem acesso devido às normas estatais -, restrições quanto ao uso do lugar pelas mesmas normas, subordinação dos moradores ao projeto antroposófico, produção de espaços de sociabilidade atravessados pela normatização, transgressões dos moradores diante das normas do lugar. É neste nível que há o embate mais contundente entre o plano da vida e da reprodução capitalista. O espaço como condição e meio de realização da vida tende a se incorporar ao processo produtivo empobrecendo as possibilidades de apropriação do espaço. É o uso do espaço, prática intrínseca à vida, que simultaneamente o produz e o transforma em meio de realização da sociabilidade entre os moradores. A redução dos usos do espaço, ou mesmo a sua normatização, conduz á tendência a perda das relações de vizinhança, de reconhecimento no outro dos problemas existentes na vida dos moradores da metrópole.

\section{A Associação Comunitária Monte Azul e um Panorama da Matriz Antroposófica}

A Associação Comunitária Monte Azul (ACMA) foi fundada no ano de 1979 por um grupo constituído por pais de alunos da Escola Rudolf Steiner e uma professora chamada Ute Craemer. A atuação desta Associação está baseada na filosofia antroposófica, e este fato explicará a organização em que está assentada a ONG. ${ }^{5}$

Sobre a antroposofia, algumas palavras já foram ditas, mas é necessário retomálas para que se compreenda o fundamento de suas ações, pois estas revelam um projeto que se confronta com outras práticas sócio-espaciais na produção do lugar. Ela é apreendida enquanto uma matriz discursiva nos termos postos por Sader (1988), isto é,

"As matrizes discursivas devem ser, pois, entendidas como modos de abordagem da realidade, que implicam diversas atribuições de significado. Implicam também, em decorrência, o uso de determinadas categorias de nomeação e interpretação (das situações, dos temas, dos atores) como na

\footnotetext{
5 “O trabalho tornou-se gradativamente intenso e, com a ajuda financeira de particulares, convênio com a Prefeitura, doações de firmas e, especialmente, colaboração (em forma de trabalho) de pessoas de dentro e fora da favela, foi possível expandir o trabalho pedagógico a todas as faixas etárias, além de melhorias no aspecto físico da favela e cuidados com a saúde, para uma vida sócio-cultural mais afetiva. (...) O trabalho baseia-se na ciência espiritual da antroposofia e pedagogia Waldorf” . Trecho de livro de Ute Craemer citado na dissertação de mestrado de Figueiredo, R., Saúde sexual e reprodutiva de mulheres de baixa renda: Favela Monte Azul - Um estudo de caso, FFLCH-USP, São Paulo, 1999.
} 
referência a determinados valores e objetivos. Mas não são simplesmente idéias: sua produção e reprodução dependem de lugares e práticas materiais de onde são emitidas as falas.” (p.143).

Tais práticas são, portanto, vividas antes de tudo, e nesta vivência se reconstrói o próprio projeto proposto.

Verifica-se, pois, uma trama complexa que embasa os fundamentos da antroposofia, tendo por idealizador Rudolf Steiner, que no início do século XX reúne algumas idéias que darão corpo a este pensamento. De acordo com a antroposofia, o homem é compreendido enquanto corpo, alma e espírito. O Corpo seria a parte física e material através da qual entra em contato com o mundo, a Alma é uma porção não física, responsável pelos sentimentos em relação aos objetos externos ou ao outro, interiorizando-os e manifestando vontades. Por fim, teria o componente do humano designado como Espírito, que é a propriedade do pensar e refletir sobre a percepção dada pela alma. É este terceiro termo que dará o equilíbrio à relação entre os dois primeiros. Desse modo, os antroposóficos compreendem este conjunto da seguinte maneira:

"Por meio do corpo somos seres objetivos, pois entramos em contato com algo que não está em nós. Por meio da alma somos seres subjetivos, pois com ela temos reações interiores absolutamente individuais. Por meio do espírito temos atividades voltadas tanto para o que é subjetivo, quanto para o que é objetivo: podemos com ele reconhecer as nossas sensações, sentimentos ou instintos subjetivos (...) Com nosso espírito temos a percepção objetiva da essência superior daquilo que percebemos sensorialmente, ou mesmo de entes que não têm manifestação física, como por exemplo os matemáticos.”6

É desta relação entre os três termos que é atribuída a capacidade altruísta do ser humano. Tal capacidade é a finalidade da vida daqueles que congregam deste mesmo pensamento, pois assim é possível a "organização social mais sadia a que estamos vivendo. ${ }^{7}$ ”. Antes, é preciso atentar para a da lógica triádica que é exposta por eles e que possui uma justificativa. Para eles, os dois primeiros membros da entidade humana

\footnotetext{
${ }^{6}$ Stezer, Valdemar, Uma Introdução Antroposófica à Constituição Humana, site www.sab.org.br. Consultado em fevereiro de 2007.

${ }^{7}$ idem
} 
são polarizações e o último contém características dos dois primeiros, mas serve como mediação entre eles, para que possa harmonizar, ou seja, garante-se a coerência da lógica.

Ainda sob esta lógica do pensamento antroposófico há os atributos dados à Alma e ao Corpo, que nos são de grande valia para entender as finalidades dos trabalhos realizados pela Associação Comunitária Monte Azul, bem como, a coerência e o encadeamento de sua estrutura. A partir deles se organiza a administração, delineia-se a estrutura funcional e mesmo o caráter da gestão da Associação. Na relação entre eles descobrimos a justificativa dos objetivos propostos pelo projeto antroposófico e que nos leva a considerar como seus objetivos se confrontam tanto com os moradores quanto com os mantenedores.

Seguindo este raciocínio, a Alma encontra-se entre a Corporalidade e o Espírito e é composta por três partes, a alma das sensações, a consciência e a racionalidade e índole. A primeira está voltada para a corporalidade, a segunda para o espírito, e a última, está ligada à razão, equilibrando as demais. Na interação entre estes três níveis é que se "manifestará" as três capacidades sociais, e eis aqui a justificativa das ações que dão o embasamento necessário para a sua atuação caritativa. Isto é, através da alma das sensações eles exercitam o Interesse e sensibilidade sociais, significando a possibilidade de conhecer o outro, ou como colocam “interessando-se pela sua vida, sua biografia, seus problemas”, também por meio dela há a detecção das necessidades e habilidades do outro. A alma racional e da índole leva à compaixão e à com-alegria, que seriam expressões da capacidade de sentir e perceber o sentimento do outro. Por fim, a alma consciência é o exercício da responsabilidade e ação sociais.

Ou seja, “É com nosso espírito, por meio da Alma da Consciência, que sentimos a responsabilidade moral de agirmos socialmente. Mas não adianta somente sentirmos essa responsabilidade: é necessário transformála em ação. Toda ação consciente, resultante de uma decisão consciente, é manifestação de nosso espírito, por meio da Alma da Consciência que, justamente como vimos, está mais voltada para ele ${ }^{8}$.

Do ponto de vista da antroposofia são estes elementos que impulsionam os trabalhos ditos sociais realizados por eles, e expõe em síntese que,

\footnotetext{
${ }^{8}$ idem
} 
A Territorialização da Associação Comunitária Monte Azul

“Temos, assim, 3 aspectos da atividade social. Inicialmente temos que nos interessar pelo próximo, e ter a capacidade de detectar quais são suas necessidades e habilidades. Em seguida (ou em paralelo) devemos sentir seus sofrimentos e alegrias. Finalmente, não basta ficarmos apenas nesses aspectos: devemos sentir a responsabilidade de ajudar o outro satisfazendo suas necessidades e possibilitando que exercite suas habilidades, colocando nossas habilidades a serviço dele, executando assim alguma ação social". ${ }^{9}$

No que se refere à estrutura da Associação, podemos verificar a lógica de seu desenho por meio de outro momento do pensamento no qual se embasam. Além da Alma, há o Corpo com quatro membros, o corpo físico, etérico, astral e o "eu". Inicialmente, começa-se da parte física, depois o etérico que é responsável pelas funções vitais e orgânicas do corpo o regulando, o astral representa o movimento do corpo, a consciência, o supra-sensível, e o "eu”, que se diferencia dos demais por considerar somente enquanto uma característica espiritual, é a individualidade superior que capacita para a integração com o outro.

Por conseguinte, a estrutura organizacional vai pari passu a esta lógica. O conjunto se constrói como algo a ser projetado nas ações, pois é visto como um funcionamento orgânico. Uma organização para manter seu equilíbrio e realizar o objetivo da prática antroposófica, necessita estar próxima do funcionamento da “natureza humana”. É nessa direção que a fala da coordenadora de desenvolvimento institucional da ACMA contribui para a compreensão do sentido da estrutura em que se desenvolve a pratica sócio-espacial de seus membros, como se observa a seguir:

"Auritimia é como se fosse um movimento leve do corpo que ajuda os corpos, porque a gente tem o corpo físico, o etérico, o astral e o eu. Resumidamente, se você está andando na rua, ai você tropeça numa pessoa no chão, a primeira coisa que você olha, é que tem um corpo ali. Não sabe se está vivo ou se está morto, não sabe nada. Ali tem um corpo físico, com uma estrutura de organização, ai falando um pouco da administração antroposofica. Você chega num domingo a tarde aqui, é a estrutura física da associação. Ai você olha e vê que a pessoa está respirando, ele tem o vital dele, que é a vitalidade. Se você chegar aqui na segunda de manhã,

\footnotetext{
${ }^{9}$ Stezer, Valdemar, Uma Introdução Antroposófica à Constituição Humana, site, www.sab.org.br. Consultado em fevereiro de 2007.
} 
você vai ver que existem os processos. Então [por exemplo], que você chegou e que o porteiro interfonou. Existe um processo aqui, isto seria o etérico, tanto do indivíduo como de uma organização. Ai o cara olha para você e diz, como você tropeça em mim e não me enxerga? Você é cega? Não está me vendo? O cara pode ser muito grosso. Ou pode falar desculpas, eu estava no meio do caminho. O que tem ai? Tem um astral. Pode estar com um bom astral ou um astral péssimo como a gente chama, que é astralidade. A gente chama isso na instituição das relações. E tem o eu que é a identidade, no nosso caso é a missão, a visão da organização e do ser humano porque ele tem um nome, ele tem uma biografia que é única dele que nenhum outro ser humano tem igual. A gente enxerga esses processos tanto no ser humano quanto na organização". ${ }^{10}$

Esse conjunto de princípios serve de embasamento para o projeto que se impõe naquele lugar, produzindo-o. Tanto em seu Estatuto (2003) como em seus folders podem ser vistos os objetivos do trabalho proposto pela ACMA e que está cimentado pela filosofia antroposófica,

“Artigo 20 - A Associação Comunitária Monte Azul tem por finalidades (Cód. Civil de 2002, art. 54, I):

I. Promover o amor ao ser humano, proporcionando oportunidades através da educação, cultura e saúde, principalmente para pessoas não privilegiadas se desenvolverem material, social e espiritualmente, estimulando-as para agirem conscientemente e com amor;

II. Promover atividades recreativas, culturais e ambientais;

III. Promover atividades educacionais para crianças, adolescentes $e$ portadores de necessidades especiais.

IV. Promover cursos de capacitação para educadores comunitários;

$V$. Desenvolver cursos de iniciação profissional para jovens e de formação profissional para adultos.

VI. Atuar como órgão de apoio e serviço à comunidade.

VII. Realizar parcerias com entidades afins.

\footnotetext{
${ }^{10}$ Entrevista concedida em 08 de março de 2006. Grifos meus.
} 
VIII. Promover atividades e campanhas educativas na área da saúde."11

Assim, o sentido das ações se mostra explícito, denotando o viés assistencialista próprio da prática antroposófica, que irá atuar, como posto acima, em vários níveis da vida dos moradores para os quais direcionar-se-à o trabalho. O conteúdo destas ações os encaminham para a atuação no chamado terceiro setor, que tem o destaque da participação das organizações não governamentais. Há textos da Sociedade Antroposófica Brasileira que versam sobre os empreendimentos nesta área e destacam o papel de relevância para o enfrentamento dos "problemas sociais”.

Também nestes textos, há menção sobre a origem de tais problemas e as formas de equacionar ou minimizá-los. Segundo eles, as causas Vão desde os efeitos do neoliberalismo na economia até a falta de solidariedade entre os povos, que promovem o desemprego, falta de moradia ou a habitação indigna, a fome, a violência, etc. Para resolvê-los bastaria basicamente atuar em quatro pontos essenciais,

“1. Esforço de empatia e consciência de cada um, 2. Esforço de se juntar em comunidades solidárias, isto é, da sociedade civil organizar-se, 3. Diálogo e cooperação entre os três setores da sociedade (empresas, governo e organizações não governamentais) e, 4. Criação de políticas públicas de inclusão nacional e internacional ${ }^{12}$

Ainda em relação à busca de soluções e iniciativas atuais é destacada a capacidade de atuação do movimento antroposófico nesta direção por eles propostos,

“Há um complexo de problemas ligados à economia e à política mundial que são assuntos não diretamente acessíveis ao movimento antroposófico. Mas, semelhante à sociedade civil não antroposófica, os indivíduos podem engajar-se no movimento de direitos humanos, no movimento pela paz, nos movimentos sociais... Eles podem também, por meio de um esclarecimento político maior e um incentivo aos protagonismo juvenil, participar dessas lutas existentes. Infelizmente, só em raríssimos casos isso acontece.

\footnotetext{
${ }^{11}$ Associação Comunitária Monte Azul, Estatuto Social, São Paulo, 2003.

12 Walter, Coralia, Iniciativas com inspiração antroposófica no Terceiro Setor, www.sab.org.br. Consultado em fevereiro de 2007.
} 
Uma visão ecológico-social das empresas pressupõe que elas consigam integrar-se com os efeitos sociais que elas mesmas geram $e$ criam. Dessa forma, elas desempenham um papel primordial no desenvolvimento dos trabalhos sociais, culturais e educacionais.

A respeito do papel das empresas devemos mencionar a idéia central da Trimembração do Organismo Social, que prevê que a vida cultural-educacional-social seja alimentada pela vida econômica. Com exceção da Associação Tobias [mantenedora da área de saúde da ACMA] é raro encontrar esse entrelaçamento econômico. É por meio do desenvolvimento das capacidades humanas que podemos criar a energia para provocar as grandes mudanças na realidade social.

No segundo item - o da desagregação do individuo e a falta de orientação interna - o movimento antroposófico parece ter mais vocação. Existem inúmeras iniciativas de educação, saúde, cultura, arte, reorganização biográfica, consultoria social em empresas e alimentação, que em resumo, procuram facilitar a procura do caminho individual espiritual (veja www.sab.com.br).

No sentido de que essas iniciativas propõem-se a serem acessíveis a todos que as procuram, independente da exclusão sócio-econômica, surgiram desde os anos 70 várias iniciativas no plano de educação, escolas comunitárias, oficinas artísticas e profissionalizantes, centros culturais e ambulatórios comunitários.

Todas elas têm um enfoque espiritual ligado à Antroposofia, embora o caminho normalmente seja de procurar soluções práticas boas para problemas prementes e só depois aparecer um real interesse pela fonte espiritual dessas práticas. É o caminho que parte do fazer, da transformação da realidade para o perguntar e querer conhecer a fonte. Os agentes sociais normalmente motivam-se pela dor do ser humano; depois de terem procurado várias maneiras de aliviar esses sofrimentos acabam, às vezes, chegando até o movimento antroposófico." 
Neste contexto, aparece o caráter contraditório das ações realizadas pela Associação. Ao mesmo tempo em que explicita algumas razões para o estado atual de degradação da vida urbana, realiza a tendência hegemônica, ao propor um solução por dentro da própria lógica que produz os "problemas sociais" elencados. Isto é um fato importante, porque desta maneira a crise que atualmente se encontra a Associação, já estava latente em sua origem. Podemos, então tomar em consideração que o conflito entre mantenedores e a Associação é imanente ao projeto proposto.

Deste conflito, que ora aparece em nossa análise, depreende-se a contradição de um projeto que a princípio trata-se da retomada das relações marcadas pelas determinações do valor-de-uso, porém, para colocá-lo em prática se subordina ao valorde-troca na medida que sua sustentação se realiza por meio dos financiamentos advindos dos mantenedores. A subordinação na qual se encontram, os levam, enquanto um dos sujeitos na produção do lugar, a ratificar a produção do espaço urbano sob a égide da sobreposição do valor-de-troca sobre o valor-de-uso restringindo as possibilidades de uso na medida em que traçam relações de poder no lugar e modificam as relações espaço-temporais existentes na favela. Esta restrição do uso se realiza porque as atividades estão diretamente relacionadas com a vida dos moradores na favela e o lugar, portanto, elas são objeto de normatização.

Para tanto, isto se realiza por meio da gestão dos serviços e da propriedade dos equipamentos e dos locais onde se realizam as atividades. Neste viés, os moradores se apresentam no centro de uma subordinação dupla dadas pelas relações de poder instituídas, já que eles são de certa forma objeto de ação da ACMA.

A seguir esmiuçamos a estrutura da Associação Comunitária Monte Azul, com suas áreas de atuação, a arquitetura de gestão e o leque de mantenedores de sua estrutura, o que nos permitirá entender o funcionamento das instâncias de decisão, as ações dela, os laços com os moradores, as normas para manutenção dos trabalhos, enfim, as relações de poder que subordina tanto a ACMA como os moradores.

\section{A Estrutura da Associação Comunitária Monte Azul e a Gestão dos Serviços}

Desde a década de 80 a estrutura da Associação está dividida em três núcleos localizados na zona sul de São Paulo. São eles o núcleo Monte Azul (considerado o "berço" da Associação), o núcleo Peinha (favela com 500 famílias, que está do outro lado da Estrada de Itapecerica) e o núcleo Horizonte Azul (bairro de periferia localizado 
no Jardim Ângela). Cada um dos núcleos possui atividades que abrangem a área pedagógica e cultural, e outras que se desenvolveram a partir das especificidades dos lugares onde estão inseridas.

No ano de 2006, apenas o núcleo Monte Azul atendeu, no conjunto das atividades, mais de 1.100 pessoas. Contando com quase 230 funcionários chamados de colaboradores $^{13}$. A ACMA ainda gerencia alguns programas atrelados à área de saúde, que através de convênio com a Prefeitura por meio do Programa Saúde da Família absorve cerca de 820 funcionários resultando em um atendimento em torno de 2.500 pessoas por ano na região.

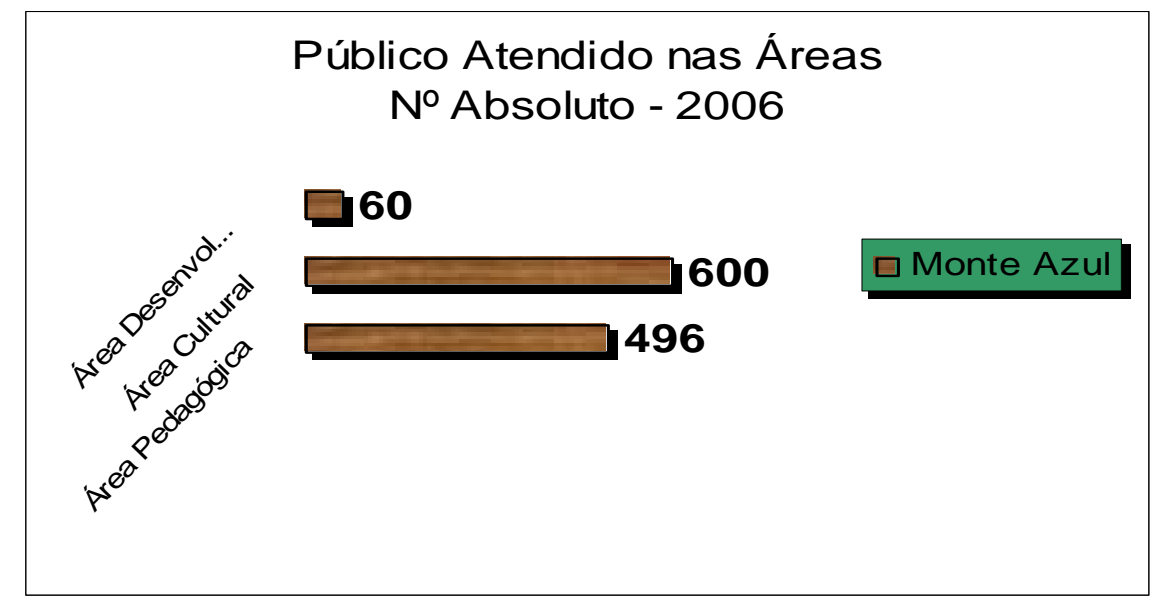

Fonte: Resumo Geral das Áreas, Associação Comunitária Monte Azul, 2006. Nota: Não consta os dados da área de saúde.

A ACMA está dividida em quatro grandes áreas: área pedagógica, cultural, de saúde e de desenvolvimento social. A primeira está atrelada ao conjunto de creches (que atende crianças entre 4 e 7 anos), núcleos sócio-educativo (ciclo I de 07-14 e ciclo II oficinas profissionalizantes para jovens de 15 aos 18 anos), agente jovem e centro terapêutico. A cultural abrange a dança, música, teatro, artes plásticas e cursos de idiomas. A área de saúde comporta os atendimentos no ambulatório (regido pela medicina antroposófica), a Casa da Trilha (especializada no atendimento aos dependentes de drogas) e, em regime diferenciado, gerencia o Programa Saúde da Família (Programa específico da Prefeitura). Sua quarta área, a de desenvolvimento social, é dividida entre as atividades de "urbanização da favela”, visitas de monitoradas à favela e à ACMA, e as aulas de informática para a comunidade.

\footnotetext{
${ }^{13}$ Os funcionários são denominados colaboradores, pois as suas atividades não se resumem apenas ao trabalho em si (exceto no Programa Saúde da Família), pois é preciso que cada funcionário esteja engajado no projeto principal da ACMA, exercendo atividades voluntárias e de assistencialismo.
} 
Para movimentar parte desta estrutura, especificamente no núcleo Monte Azul (principal), há um número de 215 colaboradores trabalhando nas diversas áreas e 13 pessoas que atuam somente no projeto de “urbanização da favela”, totalizando 228 pessoas. Deste montante, $60 \%$ são moradores da favela segundos dados da própria Associação, correspondendo a um total de 137 pessoas, que estão articuladas à Associação pelos laços de trabalho. Em um universo de quase 500 famílias residentes na favela, este número ganha expressividade, denotando o entrelaçamento da ACMA e os moradores da Monte Azul através do mundo do trabalho.

Quadro 2 - Conjunto de Atividades em cada Núcleo da ACMA

\begin{tabular}{|c|c|c|}
\hline Núcleo Monte Azul & Núcleo Peinha & Núcleo Horizonte Azul \\
\hline Programa Saúde da Família & & Programa Saúde da Família \\
\hline Centro cultural & & Centro cultural \\
\hline Ambulatório & Ambulatório & Ambulatório \\
\hline Urbanização & & Horta \\
\hline \multicolumn{3}{|l|}{ Centro Terapêutico } \\
\hline Creches & Creches & Creches \\
\hline Núcleo sócio-educativo & Núcleo Sócio-educativo & Núcleo Sócio-educativo \\
\hline Geração de renda & & $\begin{array}{l}\text { Meio ambiente (coleta } \\
\text { seletiva de lixo e horta } \\
\text { comunitária) }\end{array}$ \\
\hline
\end{tabular}

Organização: Ribeiro, F. V., 2006.

Assim, para garantir e manter os trabalhos e relações constituídas no lugar, a Associação se estrutura num híbrido entre o projeto calcado na antroposofia e nas necessidades impostas pelos convênios, este último será discutido mais adiante.

No momento, verifica-se que há uma forma de gestão das atividades da ACMA que assegura a reprodução desta mantendo as relações de subordinação. No quadro fornecido pela ACMA, vemos integralmente o organograma que expõe as atividades de cada núcleo e sua hierarquia. Dentro deste contexto, enfocaremos a organização do núcleo Monte Azul, pois é na favela Monte Azul que há duas intervenções importantes que são mediações potentes para entendermos a problemática da pesquisa. 


\section{INSERIR O ORGANOGRAMA DA ASSOCIAÇÃO}


Ao olhar atentamente o organograma e baseando-se nas entrevistas realizadas, percebemos que há um controle estrutural no processo de tomada de decisões, que no discurso da Associação aparece como uma estrutura "achatada”, na qual há uma hierarquia pouco acentuada entre os colaboradores (funcionários) e antigos fundadores da ACMA. Entretanto, nas entrelinhas da prática observada, evidencia-se um forte controle daqueles fundadores, que se reúnem na instância máxima de decisões (Metas da Associação), traçando as estratégias de realização do projeto original de base antroposófica.

Começamos por detalhar a estrutura da Associação, que possui as seguintes instâncias: comissões (festa, bolsas de estudo, embelezamento, espaços físicos, esportes, finanças, imprensa, integração, jurídica, moradia, transporte e voluntariado estrangeiro). Elas estão na base do funcionamento da ACMA e sua finalidade é a execução das tarefas decididas nas reuniões de coordenação de área. Estas, por sua vez, estão divididas, como próprio nome já destaca, por áreas. Dentro delas há as áreas nomeadas de suporte possuindo uma diferenciação devido ao caráter de importância, são elas a coordenação da área de recursos humanos, financeira e de contabilidade. A participação nelas pressupõe experiência específica, como também, um período dentro da própria ACMA. Há ainda outros patamares, a coordenação de núcleo que se reúnem para encaminhar as demandas para os três núcleos, a instância chamada de Metas Ampliadas e a Metas da Associação (instância de deliberação - topo da hierarquia), além da diretoria e do conselho, ambos de caráter consultivo. ${ }^{14}$

Segundo a responsável pela área de desenvolvimento social, as pessoas que participam destas instâncias possuem um trânsito entre elas, mas ao questionarmos sobre o local da deliberação das ações a resposta dada é, “Quem tem o poder de tomada de decisão é Metas [da Associação], junto com suas instâncias”. As instâncias com maior poder são Metas Ampliadas e Metas da Associação, e são compostas por antigos membros da Associação, em grande parte pelos fundadores. Elas têm o poder de deliberação sobre as ações de execução e gestão, balizando o que está de acordo ou não com o projeto original. Isto significa que parte de seus colaboradores/funcionários não realizam este trânsito nas instâncias com maior poder de decisão, além de mostrar que aqueles que são moradores, mesmo enquanto colaboradores, também não integram o

\footnotetext{
${ }^{14}$ Apenas para ilustrar o processo hierárquico de decisão tomamos a fala de Valéria "Eu tenho um problema aqui na minha área, eu converso com minha coordenação, se a minha coordenação acha que é importante eu levo para a coordenação de núcleo. Se a coordenação de núcleo fala, vamos pensar isto ao nível de três núcleos, vamos discutir aqui [metas ampliadas - metas da associação], então vou levando”.
} 
grupo que decidirá as ações a serem realizadas no lugar. O poder de gestão fica nas mãos do grupo fundador, pois cabe a ele a preservação dos objetivos do projeto antroposófico, que muitas vezes não estão de acordo com os anseios da população com a qual interagem diretamente. As funções dos demais campos se circunscrevem à execução, e as decisões giram em torno das formas de como realizar as tarefas vindas das instâncias superiores.

Dentre estes campos, estão as comissões que são a base da estrutura e que são importantes para agilizar a execução dos projetos. Isto é, nasceram com o intuito de descentralizar a execução das decisões das coordenações e são compostas por colaboradores que tenham no mínimo um ano de trabalho na Associação e com o perfil adequado para aquela tarefa (perfil que é definido pelos mais antigos na ACMA). A comissão de finanças é a única que exige formação na área, pois é considerada uma comissão estratégica para a ACMA.

O raio de atuação destas comissões é limitado. Elas atuam sob os direcionamentos das instâncias superiores, realizando tarefas de execução e não de deliberação. Se há dentro dela a elaboração de critérios, eles precisam ser aprovados por Metas da Associação.

Um destaque interessante é a comissão de moradores, que é agregada ao organograma da Associação como se fosse uma área específica. Este dado comporta o significado da dependência dos moradores, mesmo que no decorrer das ações entre ambos tensões apareçam, como no caso do processo de “urbanização da favela” que é objeto de nossa pesquisa.

As comissões atuam em objetos e reivindicações específicos dos colaboradores. Alguns exemplos merecem ser comentados porque revelando em quê elas atuam, permite-nos verificar como os colaboradores-moradores (parte dos funcionários que são moradores da favela) e ACMA estão entrelaçados. Este entrelaçamento representa a transformação do lugar de morada em lugar de trabalho, e por isso, se complexifica as relações entre parte destes moradores e a ACMA, seja para ratificar as ações dela seja para questioná-la.

Colocamos em destaque, as comissões de bolsa de estudo, moradia e jurídico. A primeira é responsável por distribuir as bolsas de estudos aos colaboradoresfuncionários, principalmente, àqueles ligados à área pedagógica e estas bolsas são oferecidas pelos parceiros da Associação. A segunda, a comissão de moradia, também exclusiva aos colaboradores, seleciona aqueles que necessitam de auxílio-aluguel, que 
serve como um benefício aos funcionários. Estes dois benefícios atingem parte dos funcionários que são também moradores da favela, denotando o laço de dependência deles com a ACMA. Esta dependência nos é apresentada nas entrevistas que fizemos com funcionários tendo este perfil, que no discurso defendem as ações da Associação e sua estrutura.

A última comissão, a jurídica, tem um alcance mais amplo e sua finalidade é “filtrar” as demandas por consultas desta natureza. Este serviço não se restringe aos colaboradores, podendo ser usufruído por parte dos moradores da favela, que encaminham a demanda para a comissão avaliá-la como pertinente ou não.

Estas três comissões evidenciadas representam a construção dos laços de dependência entre os funcionários e a ACMA através dos benefícios ofertados. Especificamente a comissão jurídica aponta mais um serviço que os moradores da favela podem ter acesso, estreitando as relações com a Associação ${ }^{15}$. Estes laços configuram as formas assistencialistas de ação das organizações não governamentais, e a ausência/presença do Estado em questões cruciais como moradia e educação.

Ao mesmo tempo, os funcionários e parte dos moradores se reproduzem pela ACMA, como também, ela se reproduz mantendo os recursos para sua reprodução. Isto é, em duas perspectivas: garantindo a imagem de ONG para angariar mais recursos e conseguindo a capacitação adequada de indivíduos para os quadros da ACMA, justificando seu uso nestas ações.

No que se refere à tomada de decisões internas na ACMA, uma outra comissão é posta em destaque por acreditarmos que seja importante e que mereça atenção por revelar a forma de elaboração dos critérios de deliberação internos a ACMA, que é a comissão de integração. As integrações são reuniões que acontecem mensalmente, com o intuito de debater as questões de execução do planejamento anual relativas aos três núcleos, e principalmente, o tema eleito para reflexão no ano ${ }^{16}$. Algo interessante é como ocorre a eleição do tema. Ao perguntar à coordenadora de desenvolvimento social sobre este aspecto, a reposta foi a seguinte:

\footnotetext{
${ }^{15}$ Segundo entrevista, este tipo de serviço começa a ser ofertado no período do governo Luiza Erundina por meio de um programa específico, no qual advogados assessoravam a população nas demandas relativas as questões jurídicas, isto é, um programa ligado a defensoria pública enfocando as pequenas causas. O programa se extinguiu mas o serviço continua sendo oferecido, pois alguns destes advogados fazem parte da sociedade antroposófica.

${ }^{16}$ Para o ano de 2006 o tema eleito foi "Pensar, sentir e agir". Já foram abordados em anos anteriores os temas do meio ambiente, as religiões no mundo (escolhido após o 11 de setembro de 2001), consumo consciente e o amor incondicional.
} 
“É discutido. O grupo de integração discute junto com Metas. Tem uma discussão por trás. No fundo a Ute, que é fundadora e conselheira da Monte Azul, propõe o tema”.

Este curto trecho nos leva a considerar que há uma hierarquia não tão "achatada” como parecia ser numa primeira aproximação, revelando que há estratégias dos fundadores da ACMA para manter o controle das ações da Associação. Logo, a estrutura participativa dita em discurso não se efetiva na prática. Isto se explicaria pela necessidade de assegurar as finalidades do projeto antroposófico, principalmente, por este se tornar mais fragilizado na medida em que incorpora as normas dos convênios.

Outras duas instâncias precisam ser mencionadas para compreensão do todo da ACMA. São elas a diretoria e o conselho, que são instâncias consultivas, compostos por funcionários, parceiros, apoiadores e associados da ACMA. Em ata do ano de 2001, constatamos que toda a diretoria da Monte Azul reside fora da favela, destacando que a composição da Associação são de pessoas organizadas externamente.

Toda a estrutura gestionária desemboca em um regime que mantêm as ações de caridade e assistencialistas, pois não há uma co-gestão entre aqueles que possuem o projeto e a aqueles que são o alvo das ações. As normas são elaboradas internamente a ACMA e sua prática se realiza no "chão” da favela, no sentido de se adequar às bases da antroposofia e as dos mantenedores, tornando-se de certa forma esquizofrênica, porque as finalidades são profundamente distintas.

Esta prática constrói também uma relação tipicamente assistencialista, pois na medida em que não há a inserção dos moradores nas instâncias de decisão, a interlocução entre eles se realiza como obrigação da instituição para suprir as demandas da favela, pois ela utiliza-se de seu espaço para a realização do projeto. Contudo, pelas formas contratuais principalmente com o poder público, a demanda aumenta, pois os serviços devem atender a todos, não exclusivamente a população da favela. Isto traz como conseqüência a escassez das vagas oferecidas, redundando na impossibilidade de atendimento de todos da favela.

A não socialização dos mecanismos de gestão e a falta de participação fundamentam a negação que atualmente a população faz da Associação, bem como, ratificam a territorialização dela, demarcando o processo contraditório de ação e o conflito entre os sujeitos na produção do lugar. 


\section{Mantenedores e Fluxo de Capital}

Para a realização dos serviços, a Associação conta com um leque de "parceiros" que direcionam os fluxos de capitais (atualmente não suficiente) para manter os 20 projetos existentes. Dentre eles, há diferenciações atribuídas conforme o tipo de auxílio prestado. São eles os parceiros mantenedores, os parceiros de projetos específicos e os de apoio.

Os parceiros mantenedores direcionam recursos para a manutenção da estrutura da Associação. Em sua maioria são empresas multinacionais alemãs ou ligadas as estruturas antroposóficas:

- Freunde der Erziehungskunst Rudolf Steiners (desde 1980);

- Associação Beneficente Tobias (desde 1981 - articulada a empresa Giroflex) ${ }^{17}$;

- $\quad$ Prefeitura de São Paulo (desde 1983) ${ }^{18}$;

- Galderma ;

- Ação Criança;

- Zukunftsstiftung;

- Etoile d'Azur;

- Colégio Visconde de Porto Seguro (escola localizada no Morumbi e dedicada ao atendimento aos alunos de maior poder aquisitivo);

- Rudolf Steiner Foundation e;

- Peter Koefmel.

Há os parceiros de projetos específicos, que também são organizações de cunho assistencialista em sua maioria, e empresas multinacionais, apontando a rede em que a Associação está inserida. São elas:

- Pepsico do Brasil;

\footnotetext{
17 “A Associação Tobias iniciou suas atividades na área de saúde como mantenedora da Clínica Tobias (1969) e, depois, estendeu seu campo de ação à Agricultura Biodinâmica (1974). A atuação da Associação Tobias tornou-se mais efetiva a partir de 1975, quando recebeu como doação uma parcela relevante da propriedade de uma indústria nacional de porte médio. Isso permitiu à Associação Tobias ampliar suas metas iniciais e criou as condições para fundar e manter iniciativas sociais e culturais, além de apoiar a formação profissional e a pesquisa.”, www.sab.org.br. Consultado em fevereiro de 2007. Cabe ressaltar que é ela que mantêm a estrutura para as ações na área de saúde, que tem seu fundamento na medicina antroposófica, pois o Estado na estabelece convênio com formas específicas de atuação como neste caso.

${ }^{18}$ Firmou convênio para a área pedagógica. Estes convênios são fruto das mobilizações de movimentos sociais ligados à reivindicação por creches no município de São Paulo na década de 1980.
} 
- Baxter Foundation;

- Atos Origin;

- Fundação Prada de Assistência Social;

- Unicef;

- Mahle Stiftung;

- Secretaria Estadual de Cultura;

- Rotary Chácara Flora;

- Rotary Midland Canadá;

- Fundação Raphaelstichting;

- Fundação Software AG;

- Irmãs Franciscanas da Holanda;

- Hand in Hand e;

- Acacia Stiftung.

Há também as organizações denominas de Apoio, que se destacam pela atuação na Associação por meio de serviços prestados à comunidade e não por doações em dinheiro, como os demais parceiros destacados acima. Elas oferecem desde remédios a preço de custo até atendimento jurídico à comunidade da favela, na maioria dos casos com regime de trabalho voluntário. Há ainda as empresas privadas, que conveniadas à ACMA, empregam os jovens saídos das oficinas profissionalizantes ou dos cursos de línguas realizados dentro da Associação. No conjunto destas organização de apoio temos:

- Asplan;

- Advocacia Pimentel;

- Weleda;

- Tim São Paulo SA;

- Mercuri (Hotel);

- CADEM;

- Cooperapic e/ou mkt de relacionamentos;

- Artes Gráficas Coppola;

- Sirimin Medicamentos;

- Centro de Voluntariado de São Paulo;

- Linhas e Laudas Comunicação; 
- Linguistik;

- G3S;

- Adigo;

- Centro de Formação de Professores Waldorf;

- Fundação Abrinq

- Perffil - Lab Centro diagnóstico.

Este quadro nos dá a dimensão da articulação da ACMA com empresas privadas, associações assistencialistas e o poder público para a realização de sua atuação nos três núcleos hoje construídos. Os modos como cada qual se insere, seja doando dinheiro, seja prestando serviço à comunidade ou incorporando os jovens da favela aos seus quadros de empregados, nos aponta o quanto a favela se introduz nos circuitos dos negócios da metrópole, que internamente possui formas da reprodução das relações de produção, amortecendo os conflitos. Entretanto, de que forma podemos influir que ela se insere nos negócios da metrópole? O quê a caracteriza como tal?

O papel de negócio não está diretamente atrelado à busca de lucratividade, e sim, indiretamente, pela natureza das ações das organizações não governamentais, que vão desde o gerenciamento de "urbanização de favelas" e a produção de habitação de interesse social, que muitas vezes, como será visto adiante, comportou relações de poder que impediram as experiências de politização da população e ratificaram as políticas urbanas internacionais (Banco Mundial e FMI), bem como, serve as empresas privadas, que ao financiar ações deste tipo conseguem isenções fiscais, aumentando sua margem de lucro. Além disto, este conjunto nos apresenta a importância das ONGs na reprodução das relações de produção como posto acima, porque a torna mediação entre Estado e trabalhadores, Estado e usuários dos serviços públicos precarizados, Estado e instituições internacionais e suas relações de subordinação, escamoteando o real conflito entre eles na medida em que desloca o foco dos sujeitos produtores das condições da desigualdade e da segregação sócio-espacial. A noção de negócio também está ligada ao espaço-tempo produtivo, pois as ONGs enquanto instituições que possuem uma carga burocrática considerável, necessitam da eficiência e a agilidade das empresas, rompendo com o espaço-tempo de suas ações sociais. Tornam-se empresas sem fins lucrativos, mas com toda a estrutura exigida a uma empresa convencional, com necessidades que 
transitam desde a prestação de contas até o marketing de suas ações sociais (vide visita monitorada e seu planejamento)

É por esta razão, que a necessidade das normatizações de uma ordem distante (instituições, empresas privadas ou o próprio Estado) se apodera deste lugar, pela sua potência de realização da reprodução das relações de produção para a reprodução do capital. É a tendência hegemônica que somente se realiza concretamente no lugar. Além da propriedade de negócio em si (lugar como negócio), na proporção que a lógica empresarial penetra na Associação para garantir a manutenção dos serviços e as empresas mantenedoras garantem abatimentos em impostos, há também, a introdução de parte dos moradores aos códigos ligados à competição, próprio da cotidianidade, que tem por centro as relações de troca e o consumo, para garantir uma mão de obra especializada aos serviços das próprias empresas mantenedoras.

Podemos exemplificar tal idéia se pensarmos nos jovens que estão sendo preparados para um mercado de trabalho (cada dia mais restrito), ou seja, as empresas apoiadoras escolhem somente alguns poucos jovens, geralmente os mais destacados. Este fato engendra uma competição entre eles, que desgasta as relações de solidariedade com o outro, impedindo a produção de uma identidade coletiva no âmbito de sua realidade. Este é um dos fatos que nos aponta a degradação da vida, que pautada nas relações de troca, empobrece as possibilidades de resistência, principalmente para os mais jovens, que têm suas relações calcadas na competição.

Isto se revela em conversa ${ }^{19}$ com um dos moradores da Favela, na qual se refere aos que estão trabalhando na Associação ou que faz as oficinas, como os “jovens escolhidos”, pois estão de acordo com os projetos propostos.

O importante é examinar que as atividades realizadas e a gama de parceiros e apoiadores mostram ao mesmo tempo a extensão e força de territorialização da Associação, na medida em que consegue tanto executar quanto gerir toda esta estrutura. Um bom exemplo desta eficácia se confirma quando, no governo de Marta Suplicy (2000-2004), a Associação é escolhida, no ano de 2001, como uma das ONGs com os requisitos adequados para gerir o Programa Saúde da Família, programa este que irá incorporar o triplo do número de funcionários existentes nos três núcleos.

\footnotetext{
${ }^{19}$ Este depoimento não foi gravado.
} 


\section{Um Exemplo de Atuação}

Somente a título de ilustração do poder de gestão desta ONG incursionamos por sua atuação em um programa específico, o Programa Saúde da Família.

O Programa Saúde da Família (PSF) é uma política pública para a área da saúde, que consiste no atendimento de famílias por agentes de saúde, no qual se faz uma avaliação de cada membro da família, encaminhando-os, se for necessário, aos postos de atendimento (Unidades Básicas de Saúde - USB). Estes postos possuem médicos, enfermeiros e auxiliares de enfermagem, além da gerência do posto e os demais profissionais necessários ao seu funcionamento. Esta estrutura é gerida pela ACMA, com um total de 820 funcionários $^{20}$, atendendo cerca de $60 \mathrm{mil}^{21}$ famílias (aproximadamente 240 mil pessoas) nos bairros do Jardim São Luís e Jardim Ângela. A casa na qual está alojada o projeto pertence a Associação - antes era a antiga casa que abrigava os voluntários estrangeiros.

A Associação, para gerir este programa, utiliza-se da estrutura interna de recursos humanos e financeiros, dos profissionais da área de contabilidade e compras, que realizam as atividades de suporte para o funcionamento pleno do programa conforme as recomendações do convênio assinado.

A atuação da Associação se estende por um grande raio na periferia sul de São Paulo, pela incorporação da gestão deste programa específico. Cabe ressaltar que este atendimento do PSF é distinto do efetuado nos ambulatórios existentes nos núcleos da Associação, pois estes últimos possuem claramente a vertente da medicina antroposófica, algo que não acontece no atendimento do PSF que segue as diretrizes das normas da Prefeitura.

Esta atuação demarca claramente dois pontos: a incorporação e subordinação às normas do Estado por um lado, e por outro, a capacidade de territorialização da ACMA por meio da estrutura construída.

\footnotetext{
${ }^{20}$ Valéria Carrilho em entrevista no diz "Os funcionários são contratados pela Monte Azul, se fosse pela Prefeitura iria inchar muito o quadro, e ai se não desse certo o programa, ele iria abortar e não teria como mandar embora”. Isto demonstra como as organizações não governamentais possuem um papel estratégico para a lógica do Estado mínimo e o processo de precarização das condições de trabalho na metrópole destes que se inserem neste programa.

${ }^{21}$ Dados fornecidos pela própria ACMA.
} 


\section{A Crise no Período de Reprodução do Lugar}

Esta estrutura de grande porte da ONG necessita se reproduzir por meio dos serviços que prestam. Como dito anteriormente, a relação de subordinação se faz presente por meio dos contratos estabelecidos entre a Associação e seus mantenedores e desde este ato aparentemente equilibrado contêm o conflito de finalidades de cada sujeito apresentando que a crise é imanente a esta relação. Atualmente, esta crise eclode em seus três níveis, econômico, político e social.

O papel dos convênios é central nesta crise e na subordinação da ACMA. Segundo Carrillo,

“Em 83 começam os convênios com a Prefeitura. O convênio sempre foi caráter de educação, para a área da saúde a gente nunca conseguiu convênio. Quem bancou a gente foi outra, Associação Beneficente Tobias [na área da saúde]. A Associação Tobias ela foi criada no modelo que a gente acha que é referencia, que é a partir da Giroflex [empresa multinacional]. A Giroflex, um dos fundadores destinou parte dos recursos da Girofex para uma área social, que era a Associação Tobias, $e$ ela apóia iniciativas com cunho antroposófico, e é a partir dele que a gente paga toda nossa estrutura médica dentro do ambulatório, hoje inclusive.”

No conjunto dos convênios, que se ampliaram no decorrer dos anos, observa-se que em boa parte deles, há a exigência de uma série de normas a serem cumpridas. São as planilhas de gastos, de custos, de prestação de contas, para demonstrar a eficiência do uso dos recursos muitas vezes estatais. Este trabalho a ser realizado pelas ONGs as inserem no desafio de montar um aparato de funcionários para administrarem todos os recursos e, desse modo, estruturando um quadro burocrático. Todavia, os recursos que chegam até elas não prevêem estes serviços, apenas aqueles para atenderem diretamente a população. O paradoxo está no aumento da exigência nos detalhes das prestações de contas - cada mantenedor o estabelece de determinada maneira - sem prever recursos para tais atividades.

Este fato acarreta uma crise profunda - financeira, principalmente - nas chamadas instituições sociais, fazendo-as mergulharem no mundo da burocracia para justificarem o fluxo de verba dos financiadores, ao mesmo tempo, que não possuem as 
verbas suficientes para tal, mas tentando sempre garantir os serviços prestados. Esta situação é um dos pontos atuais da crise de atuação da ACMA, pois garantir o fluxo de verbas significa provar que a necessidade "fim", como pagar um professor, precisa daqueles que farão a contabilidade exigida pelos próprios fornecedores das verbas. A crise que está atrelada a estrutura em que se fincou as bases da ACMA, ou seja, a estrutura de organização não governamental, que ao mesmo tempo possui características de empresa privada sem fins lucrativos com a finalidade de realização dos serviços que o Estado não cumpre, devido a lógica neo-liberal do Estado mínimo. Acarretando a precarização dos serviços, redução dos salários dos funcionários, na medida que transfere a crise para as ONGs.

Enfim, temos a transferência dos problemas à esfera do chamado terceiro setor, aparecendo como uma crise de “sustentabilidade”, que necessita ser sanado por este próprio corpo administrativo. A coordenadora da área de Desenvolvimento Institucional revela esta crise, quando nos aponta as dificuldades e desafios que hoje enfrenta dentro da Associação para manter os serviços prestados:

“Eu tenho empresas que estão apoiando aqui, mas são empresas que tem que ser muito conscientes para entender que precisa dessa essa estrutura para que o todo aconteça, porque isso faz parte do fluxo. Então, isso é muito difícil, porque ninguém quer doar para uma estrutura financeira, não tem que doar para o contador, pra mim, as pessoas querem dar para as crianças, mas é lógico que isso faz parte do todo. (...)

Mesmo do Estado, quer dizer, os convênios cobrem... porque é assim, o convênio ele tem uma forma, ele tem uma forma de prestação de contas para todas as entidades, e cada entidade acaba trabalhando um pouco dentro do seu perfil, mas a gente luta muito nessa questão do convênio, porque nem tudo a gente consegue responder da maneira como eles querem. Nem sempre a pergunta se encaixa com nossa resposta. Então, a gente batalha muito para conseguir algumas coisas, conciliar algumas coisas que a gente entende por verdadeiro. Então, a prestação de contas muitas vezes é uma loucura, eles permitem algumas coisas e não permitem outras. E no fundo a gente precisa de tudo. Então, quem paga o prestador de contas? A prefeitura banca os educadores, banca o percapita, mas é muito maior. Eles bancam uma parte e a Monte Azul entra com toda a outra parte. Se você pegar o valor percapita, ele é muito maior em outra 
instituição, porque precisa de um contador, você precisa estar legalizado, você precisa pagar imposto, você precisa recolher impostos, tem toda uma estrutura por trás. Então, assim é importantíssimo, o maior parceiro nosso é o Estado realmente. Eu acho que a gente tem um privilegio, porque as pessoas respeitam muito o trabalho da Associação."

A entrevista realizada com a responsável pelo desenvolvimento social, na qual alguns pontos foram levantados para compreender a situação de crise em que se encontra a Associação, delineando os desafios e dificuldades do presente, diz que houve de 1979 até 2006 um crescimento imenso dos trabalhos da ACMA, de 120 pessoas no início, para mais de mil pessoas (sem o PSF) atendidas. Entretanto, as receitas não cresceram na mesma proporção.

Ela atribui este problema a “falta de visão" das empresas privadas e do poder público sobre a totalidade das atividades ao realizar os projetos sociais, porque para continuar com a mesma qualidade nas atividades que atingem diretamente as pessoas, é preciso das chamadas atividades “meio”. São elas encarregadas da prestação correta das contas e da burocracia, que acompanha e garante o encaminhamento dos fluxos de verbas à ACMA.

O que nos coloca que estas atividades "meio" começam a se tornar mais importantes, já que a burocracia exigida nos convênios ultrapassa as atividades em si (que atingem diretamente a população). Então, é preciso negociar muito com as empresas e o poder público, ceder em alguns momentos e convencer os parceiros da necessidade dos trabalhos nos bastidores. Quando não se consegue abre-se mão de outras prioridades para não perder as demais parcerias.

"Você tem 20 projetos na Monte Azul e o número de papéis, de burocracia, o fluxograma é imenso. Como é que você faz para dar conta de uma folha de pagamento, da contabilidade, do financeiro, do cheque, do pagamento de notas, da transferência. Um de nossos principais pilares é a transparência. Isso que faz que muitos parceiros venham buscar a Monte Azul, essa coisa da transparência financeira. [grifos meu] Então, a gente não pode perder a qualidade aqui. E nos projetos, cada vez menos, eles querem apoiar aqui[atividade meio], que é o alicerce que eu chamo, eles querem cada vez mais apoiar o público direto. Eu tenho empresas que estão apoiando aqui [atividades "meio"], mas são empresas que tem que ser 
muito conscientes para entender que precisa dessa estrutura para que o todo aconteça, porque isso faz parte do fluxo, então isso é muito difícil, porque ninguém quer doar para uma estrutura financeira, não tem que doar para o contador, pra mim, as pessoas querem dar para as crianças, mas é lógico que isso faz parte do todo. Então, esse é um dos maiores desafios nesse sentido, trazer a consciência as empresas de que essa estrutura precisa existir para que as pessoas que trabalham nas pontas, com o público alvo tenham uma tranqüilidade de trabalho ali. Então, a gente segura as pressões aqui de prestação de conta, a gente segura aqui toda essa parte de pagamento, de salários, são seres humanos trabalhando com a gente. Então, a gente segura isso aqui para que eles possam executar o trabalho deles como educadores, como área de saúde, como produção cultural. Então, isso precisa estar funcionando”.

Esta fala nos faz perceber a necessidade de assegurar uma estrutura específica para responder a todas as demandas burocráticas exigidas. Isto explica muito o próprio déficit (R\$ 20 mil por mês segundo membro da ACMA) da ACMA, pois os convênios não direcionam fluxos para esta estrutura, são os parceiros mantenedores que atendem esta necessidade. Este ponto localiza a crise de "sustentabilidade"22, como eles denominam, da ACMA, já que para a realização dos projetos é preciso realizar todo um processo burocrático da qual faz parte toda a instituição. De acordo com Gohn isto que diferencia profundamente os movimentos das ONGs, para a autora

“As organizações são institucionalizadas, os movimentos não. Elas podem ter sistemas de relações internas informais, pouco burocratizadas, mas precisam ser, no mínimo eficientes. Elas têm de se preocupar com a perenidade para sobreviver, e ter um cotidiano contínuo. Os movimentos não; eles têm fluxo e refluxos, não são exatamente estruturais funcionais. São aglomerados polivalentes, multiforme, descontínuos, pouco adensados, não necessitam compromisso com a eficácia operacional, a não ser algum tipo de resultado para suas bases. Eles não têm de fazer balancetes, prestar

\footnotetext{
${ }^{22}$ Depoimento de Valéria, "Então, são questões assim que as pessoas perguntam na captação de recursos, essa questão da sustentabilidade é o que me preocupa muito mais hoje. E que é um caminho esse ano para a gente estudar, pra gente trabalhar. E eu e a Renati estamos dispostas sim, a ir em alguns lugares, ver como funciona a sustentabilidade e tudo, pra começar a pensar isso de uma forma mais real, para depois partir pra uma ação. Por enquanto, então, isso é uma estratégia da Monte Azul de médio a longo prazo. Essa questão da sustentabilidade mesmo. A gente tem, o que é muito importante são os parceiros da Monte Azul, que são os parceiros mantenedores que apóiam essa estrutura."
} 
contas ou pagar funcionários. As ONGs têm tudo isso no seu cotidiano; seus orçamentos ocupam a maior parte do tempo dos dirigentes. Em síntese, a lógica que preside as ONGs tem de se basear na ação racional." 49

É esta estrutura institucional que vai submetendo o projeto da Associação às normas das empresas e do poder público, para que ela continue se reproduzindo. O impacto se vê na vida cotidiana dos habitantes, que se colocam sob uma dupla subordinação, as normas da ACMA e as normas das empresas privadas e do poder público.

Para exemplificar, citamos um exemplo de mudança da prática da ACMA pela subordinação as normas dos parceiros, que produz um impacto direto na relação com os seus beneficiados (grande parte os moradores da Monte Azul). Este exemplo se refere a área alimentar, na qual a Prefeitura, como um mantenedor, só encaminha alimentos embutidos (salsicha) para as crianças das creches, substituindo os cereais e integrais, que são a base da alimentação considerada de "boa qualidade" na perspectiva antroposófica. A ACMA, por sua vez, não possui os recursos para suprir esta necessidade, se submetendo a este tipo de alimentação. Este ato revela a ação do Estado de igualar o desigual, homogeneizando a vida das pessoas e, inserindo-as em uma mesma dieta alimentar, base vital da reprodução da vida.

Em resumo, ao nível econômico, a Associação se encontra em uma profunda crise para dar continuidade aos trabalhos por ela geridos, mas se torna a mediação para a realização dos fluxos de capitais que darão vantagens as empresas mantenedoras e de certo modo, equaciona em parte o problema de gastos do Estado. Do ponto de vista das relações de poder, ela se subordina as normas destas instituições (empresas privadas) realizando as determinações da ordem distante no lugar, e seu projeto se reproduz precariamente. No âmbito social intensifica a normatização no lugar em que se territorializou subordinando aqueles que lá vivem aumentando o abismo existente entre ambos.

Estas subordinações, que perpassam a produção deste lugar, são necessárias, do ponto de vista da totalidade da metrópole, para garantir o domínio do espaço periférico para a realização da tendência hegemônica da reprodução capitalista. Isto é, para "controlar” as tensões geradas pela segregação sócio-espacial, para diluir as "barreiras" ou para produzir as condições da própria reprodução. Contudo, esta dupla subordinação não se realiza linearmente. Há transgressões as ações da Associação e o conflito com os moradores se instala. 
Algumas considerações podem ser tecidas, a partir da ordem que tentamos construir das relações que a ACMA engendrou:

A) A primeira relação tecida no âmbito da produção do lugar é a dos moradores - colaboradores pelos laços de trabalho, e moradores-beneficiados pelos vínculos dos serviços prestados. Isto garante a dependência dos residentes na favela à Associação, pois o trabalho e os serviços possuem um teor básico para a vida da população, e na periferia eles são elementos raros. Perder estes serviços e o trabalho significa entrar no circuito das privações pela qual a periferia é estrategicamente relegada. É esta condição que compreendemos enquanto necessária para a subordinação dos moradores no lugar, e que permite a territorialização da ACMA;

B) A segunda, é a configuração da Associação compreendida através de seu aparato estrutural, de atividades promovidas, do número de colaboradores e voluntários, do volume de pessoas atendidas, do conjunto de empresas privadas, associações e o poder público, que a mantém e a apóiam, do fluxo de verbas e de atratividade para captação de projetos de grande vulto (Programa Saúde da Família) nos dão a dimensão do poder de terriorialização na periferia, destacadamente nos pontos em que ela possui seus núcleos. Podemos considerá-la, nestes vários aspectos, um elemento que traz a tendência de realização da sobreposição do valor-de-troca sobre o valor-de-uso, na medida que se torna um negócio para empresas privadas (perspectiva de empresas com responsabilidade social e abatimento em imposto de renda, por exemplo), e negócio para o poder público, que realiza através de organizações não governamentais, o Estado mínimo (exemplo é o Programa Saúde da Família) e permite um certo controle político das tensões sociais (saneamento de certos serviços básicos - saúde e educação impedimento da produção de autonomia da população);

C) A terceira mostra que a estrutura na qual se alicerça a ACMA representa traçar quais os sujeitos externos (aqueles da ordem distante - instituições privadas e estatais) em que ela está articulada. Significa considerar uma relação conflituosa, pois há diferenciações nas estratégias. Desse modo, compreendemos que há um embate de projetos entre ambos. A Associação com sua base de atuação advinda dos termos da antroposofia tenta promover um desenvolvimento dos indivíduos, conforme as características do 
assistencialismo (sem um caráter de autonomia e inserção no mundo do consumo), mas se confronta com a produção de um mundo calcado na burocracia (na qual ela é mais importante do que as atividades de ponta), noção vinda juntamente com as verbas recebidas pelas empresas privadas e do poder público. Por meio das negociações a Associação empobrece seu próprio projeto para manter o fluxo de verbas para as ações. Este empobrecimento é uma das conseqüências do processo de homogeneização empreendido pelo Estado, ao sucumbir as diferenças por meio de políticas públicas que não consideram as particularidades dos lugares na metrópole;

D) A próxima tem a ver com a estrutura, que também apresenta as formas de deliberação de estratégias e ações da ACMA, apontando que mesmo na tentativa de algo menos hierarquizado não possibilita uma ação participativa, central para as experiências de politização da vida cotidiana dos colaboradores e fortalecimento nos embates com as normas da ordem distante. Sua atuação perpetua as relações de hierarquia como condição necessária ao não rompimento dos princípios do projeto antroposófico. Como conseqüência, a autonomia e a identidade concreta não se produz, fragilizando a própria Associação quando ela necessita se defrontar com empresas privadas, poder público ou mesmo, os sujeitos responsáveis pelo tráfico de drogas que insiste em se territorializar no lugar;

E) A última que será melhor desenvolvida adiante refere-se ao fato de que a Associação simultaneamente contêm e rechaça as possibilidades de apropriação do espaço urbano. Ao nos debruçarmos sobre as mediações efetivadas a partir das experiências culturais daqueles que participam dos cursos, percebemos as possibilidades de expressão da realidade na qual se vive. São nos momentos de uso do espaço da Associação que encontramos as transgressões, pois pela mediação do teatro os jovens necessitam exercitar a reflexão sobre suas condições, respeitar um coletivo e experimentar o uso do corpo. Tais ações são escassas na metrópole, pelo recuo dos espaços de sociabilidade e de experiências coletivas, conseqüência do avanço da dominação do espaço para a introdução deste mesmo nas relações de troca. No caso das experiências desenvolvidas nos mutirões para a "urbanização da favela” houve ganhos em prol do espaço de uso em detrimento do espaço privado, como o embate entre moradores que queriam garagens para seus 
carros e os demais que lutavam por uma área de lazer. Todavia, as experiências mencionadas são entrecortadas pelas normas e supervisão da Associação, que se territorializou no lugar, impedindo o avanço destas experiências no sentido da autonomia dos moradores para a plena realização da cidadania. As experiências que extrapolavam as subordinações transgressões - como o teatro do oprimido, que coordenadores deste núcleo queriam experimentar, foram descartadas num embate interno à Associação. A comissão de moradores - criada por incentivo da própria ACMA $^{23}$ - foi aos poucos subsumindo as diretrizes da Associação, se enfraquecendo por se construir em bases de cunho assistencialista (diretriz norteadora da ACMA).

Esta caracterização da matriz discursiva antroposófica, a forma de gestão e a estrutura na qual ela se alicerça nos apresentam o conteúdo de sua territorialização, do mesmo modo que nos lança aos conteúdos desta centralidade na periferia. Nos apresenta que a produção deste lugar esta imbricada com a produção da metrópole contendo contradições a partir do conflito entre os sujeitos.

Este conjunto de ações apenas se realiza na medida que produz um espaço para tais atividades, porque o espaço é condição e meio desta reprodução. Desse modo, dentro da favela, principalmente, que estão localizados os prédios da ACMA transformando a morfologia da favela.

\footnotetext{
${ }^{23}$ Segundo conversa com um antigo funcionário, a prática da Associação Comunitária Monte Azul foi no princípio construir um barracão onde os moradores se dirigiam para pedir ajuda, demonstrando a forma mais contundente de serviços assistencialistas. Após a entrada de um grupo de funcionários politizados na ACMA (não moravam na favela), resolve-se incentivar os moradores a se organizarem numa comissão para tratar dos seus interesses. Data daí organização para a realização da urbanização da favela. Porém, o trabalho político é barrado por um intenso conflito dentro da ACMA, pois a concepção de política estava atrelada ao âmbito partidário. Isto não significa que ela não tenha uma atuação política. Arriscamos a interpretar esta recusa à política como uma forma política de dominação do espaço, através de um discurso assistencialista.
} 


\section{A Morfologia da Favela: Os Prédios da ACMA e o Centro Cultural}

No mesmo lugar onde se localizam as casas com uso residencial, há aquelas dedicadas as atividades da ACMA, e este fato demonstra a territorialização da Associação no perímetro da favela e aponta o entrelaçamento das reproduções da vida dos moradores e das ações empreendidas pela instituição. No total são oito casas onde estão instaladas as creches, a cozinha e o refeitório. Há ainda quatro prédios que abrigam o ambulatório, as oficinas profissionalizantes, a padaria e a biblioteca. De acordo com Valéria Carrillo ${ }^{24}$, esta territorialização é necessária para o bom funcionamento das atividades, explicando que cada prédio representa:

“Pontos de Luz. Não é um prédio que tem todos os serviços. Se você quiser o serviço você vai até esse prédio, mas o serviço está distribuído dentro da favela. Então são vários pontos de luz, que permite que você seja obrigado a andar pela favela para você poder fazer o trabalho. Faz com que circule gente, circule energia. É um diferencial quando você consegue descentralizar esses processos.”

Isto significa a necessidade da presença da Associação dentro da favela, próximo da população que irá atender. Esta inserção é o modo concreto de introdução das normas para a realização do projeto da ACMA no perímetro da favela, levando a cabo o processo de territorialização (expressão das relações espaciais de poder). É a necessidade da produção do lugar com as referências desta matriz, que somente é materializada na medida em que há o entrelaçamento das relações sociais dos moradores e dos membros da Associação, transformando a prática sócio-espacial.

Os “pontos de luz” são os prédios onde se exerce as atividades da ACMA. Destacaremos a seguir os seus usos e funções:

1 - O ambulatório médico e odontológico é um dos maiores prédios, com quatro pavimentos, onde são atendidos moradores da favela e de seu entorno gratuitamente. Este trabalho foi um dos primeiros juntamente com a área pedagógica. Houve, na década de 70, a construção de um grande barracão em madeira para abrigar os profissionais da área, que trabalhavam voluntariamente. A construção se realizou pelo

\footnotetext{
${ }^{24}$ Coordenadora da área de Desenvolvimento Institucional da Associação Comunitária Monte Azul.
} 
sistema de mutirão com os moradores, do mesmo modo, no ano de 1985, há o erguimento do prédio em alvenaria.

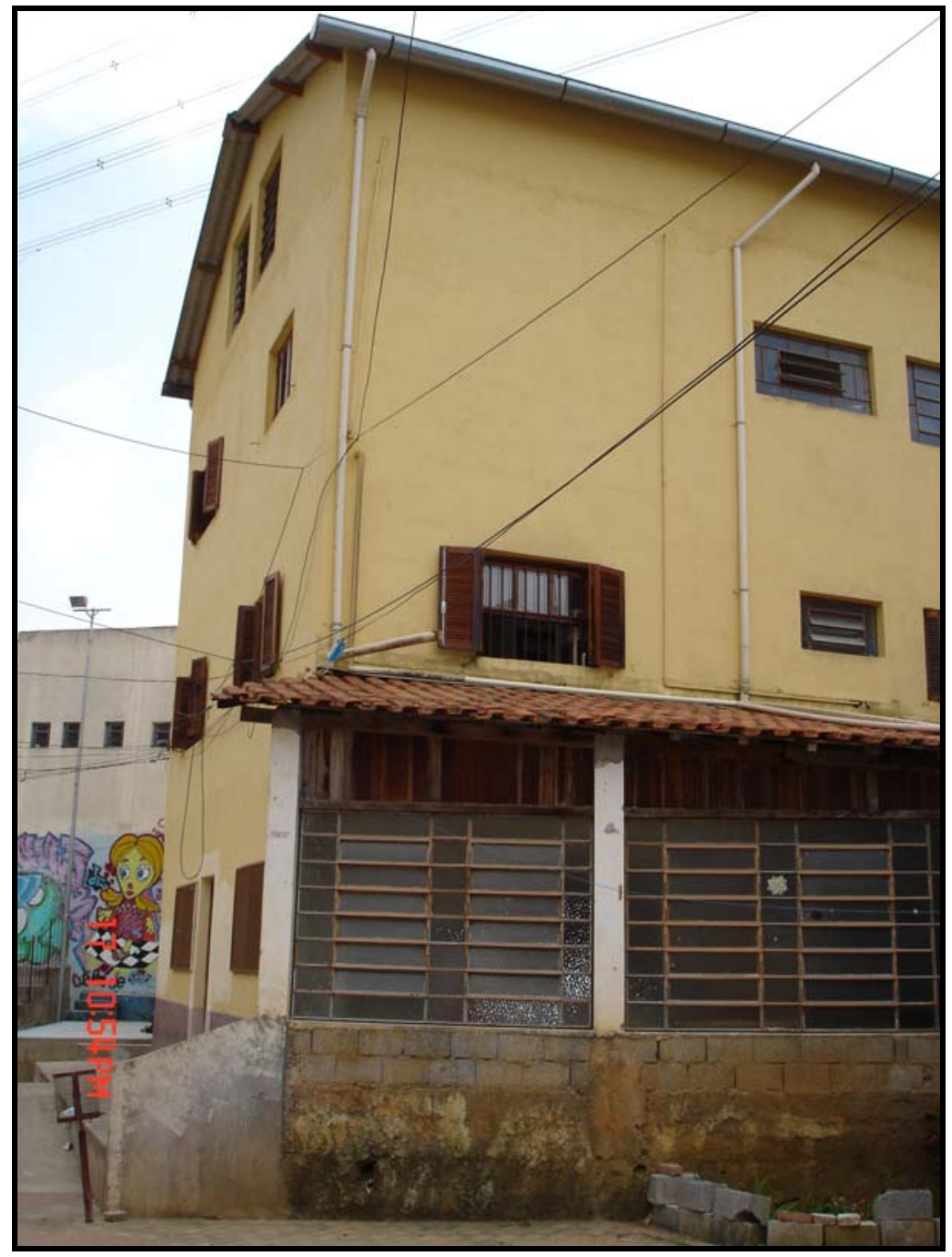

Foto 09 - Ambulatório da ACMA

Autor: Ribeiro, F. V. Jan/06

Nele trabalham voluntários, moradores e profissionais da área de saúde (alguns também moradores da favela). Há dentistas, pediatras, ginecologistas, clínico geral, fisioterapeuta, psicólogo, e aqueles que dão suporte, como as enfermeiras, auxiliares de enfermagem, auxiliar de limpeza e auxiliar de dentista. Estes profissionais oferecem os serviços para as crianças das creches e do centro terapêutico.

O trabalho é orientado pela medicina antroposófica como detalha Merege:

“O trabalho do ambulatório da Favela Monte Azul se orienta pela Medicina antroposófica cuja proposta é ampliar a cura, trabalhando o desenvolvimento do ser humano como um todo, lado espiritual e físico, racional e emocional. Não se restringe a curar os doentes com o atendimento ambulatorial e medicamentoso (sempre homeopático). Também são desenvolvidas ações preventivas tais como melhoria das 
condições de moradia, alimentação e vestuário; a contribuição para a oferta de empregos promovendo qualificação profissional e criando frentes de trabalho e melhoria da qualidade de vida em geral. Além disso, orientada pelos preceitos da Antroposofia, a ACMA conta com psicólogos e terapeutas voluntários que desenvolvem atividades de terapia artística, biografia, massagem rítmica e quirofonética, previamente indicadas pelos médicos, no intuito de acelerar o processo de cura. Em razão desta filosofia o ambulatório não tem atendimento de pronto socorro",25

Neste mesmo levantamento feito por Merege sobre as condições de vida na favela no ano de 1999, há a indicação de que 97\% da amostra já haviam utilizado ao menos uma vez os serviços do ambulatório, com destaque para os acompanhamentos de gravidez - pré-natal - 52\%, e 26\% dos moradores tinham alguém dentro de casa que havia feito o parto no ambulatório. Neste ano, houve um atendimento de mais de quatro mil pacientes. De acordo com os dados fornecidos pela própria ACMA (2005), a média de atendimentos ao ano é de 2.500 somente no ambulatório.

2 - Há o prédio onde estão instaladas as oficinas profissionalizantes, a lojinha (chamada de geração de renda), e salas de algumas áreas. Ele possui dois pisos, sendo que no inferior, funciona a oficina de marcenaria, tecelagem, corte e costura, e a padaria. No superior, há a oficina de reciclagem, oficina de panificação, sala de informática, sala da área de urbanização, a loja dos materiais produzidos pelos profissionais contratados (não há venda dos produtos feitos pelos alunos que estão realizando as oficinas - eles podem levar todos seus trabalhos para a casa), e dependências para a área pedagógica.

\footnotetext{
${ }^{25}$ MEREGE, Luiz Carlos, Análise de formações comunitárias em favelas - Metodologia, perspectivas e resultados - o modelo da Associação Monte Azul, Fundação Getúlio Vargas, São Paulo, 2001, pp.23.
} 


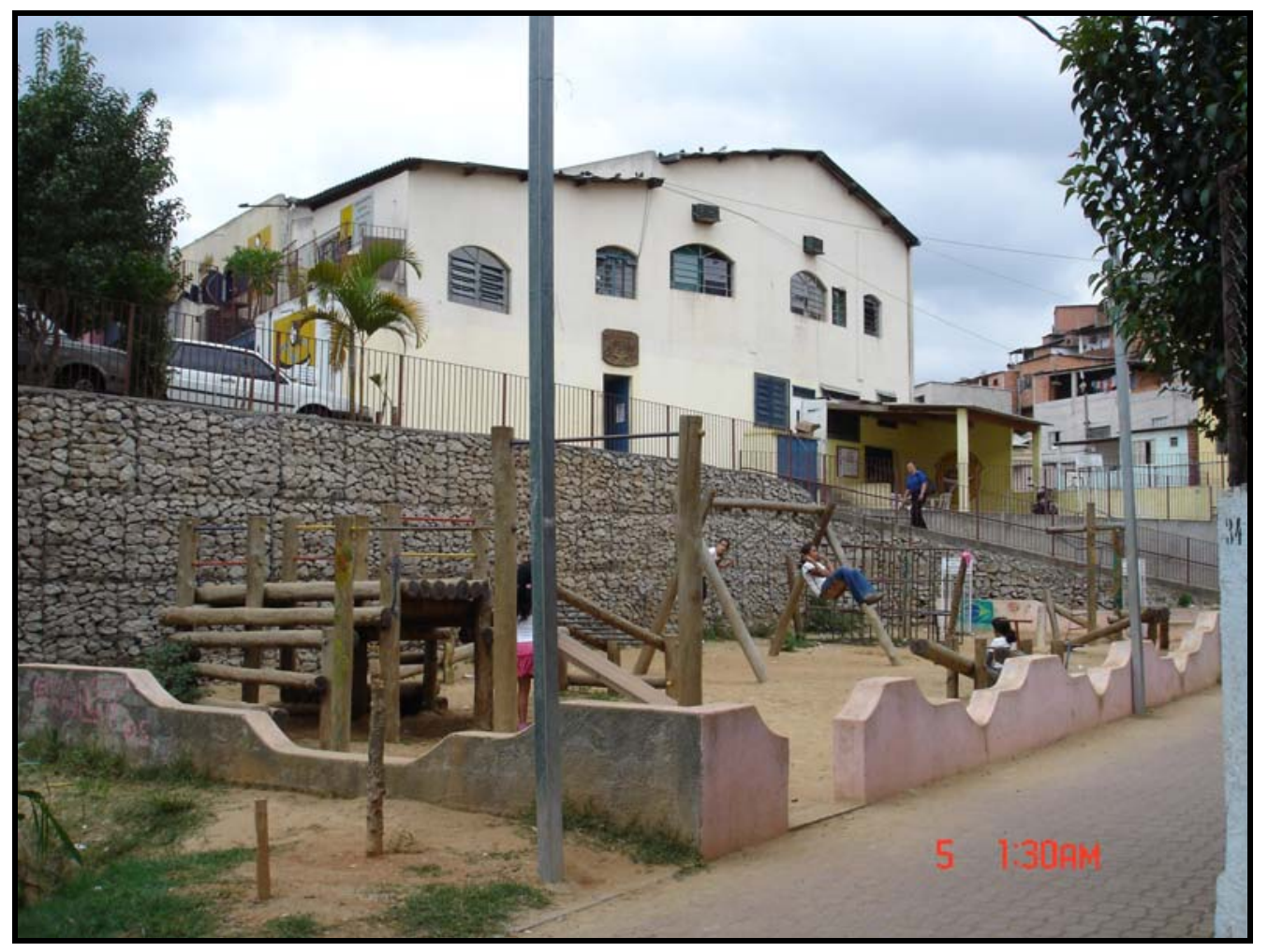

Foto 10: Prédio principal da ACMA na favela Autor: Ribeiro, F.V. Out/2006

As oficinas fazem parte da área educacional, foco central de atuação da ACMA, que atende jovens de 14 à 18 anos. No ano de 2006, está sendo atendido o total de 90 jovens (moradores ou não da favela) só no núcleo Monte Azul.

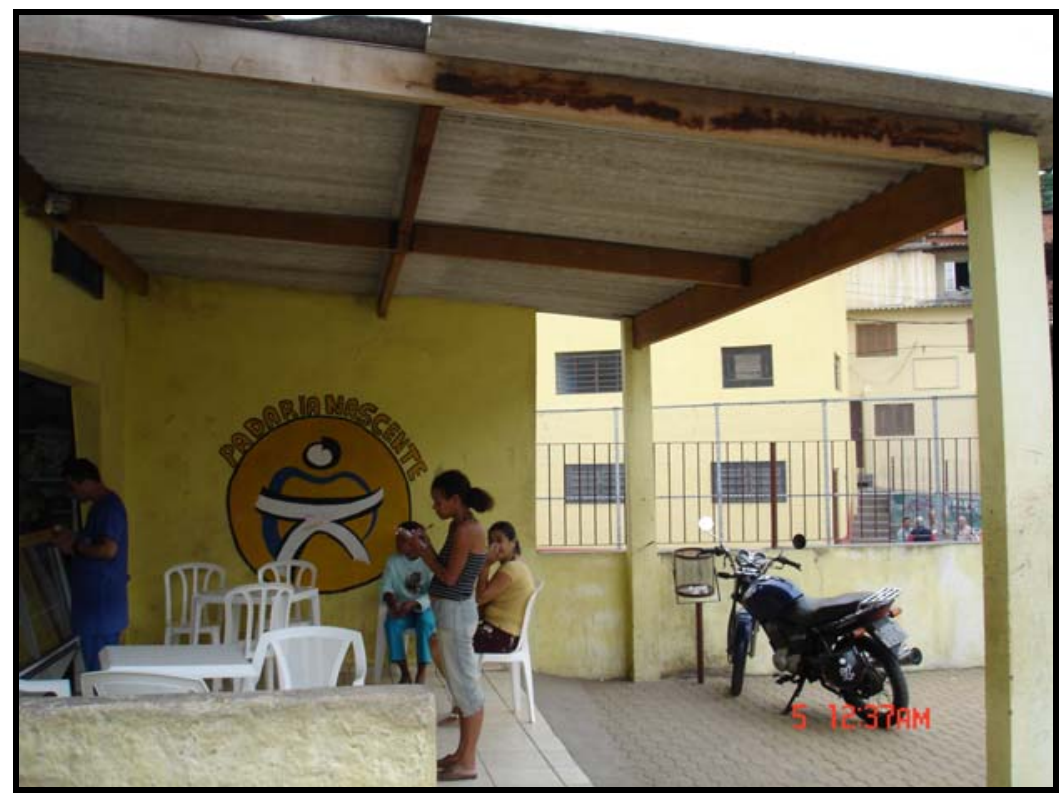

Foto 11: Padaria da ACMA Autor: Ribeiro, F.V. Out/2006 


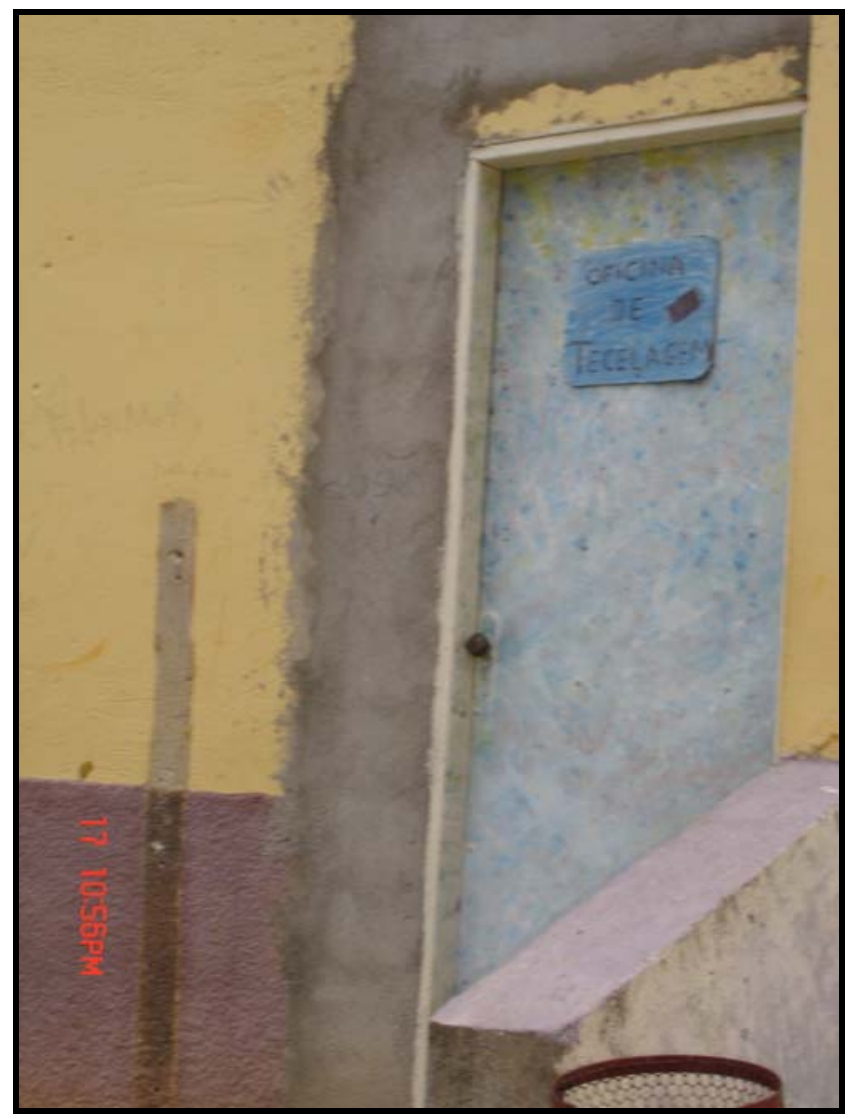

Foto 12: Porta de entrada para a Oficina de Tecelagem Autor: Ribeiro, F. V. Jan/2006

3 - Nas oito casas pertencentes a ACMA, temos as creches, que em 2006 estava atendendo um número de 170 crianças (moradoras ou não da favela), e o refeitório, no qual os colaboradores, alunos, voluntários e visitantes fazem suas refeições. 


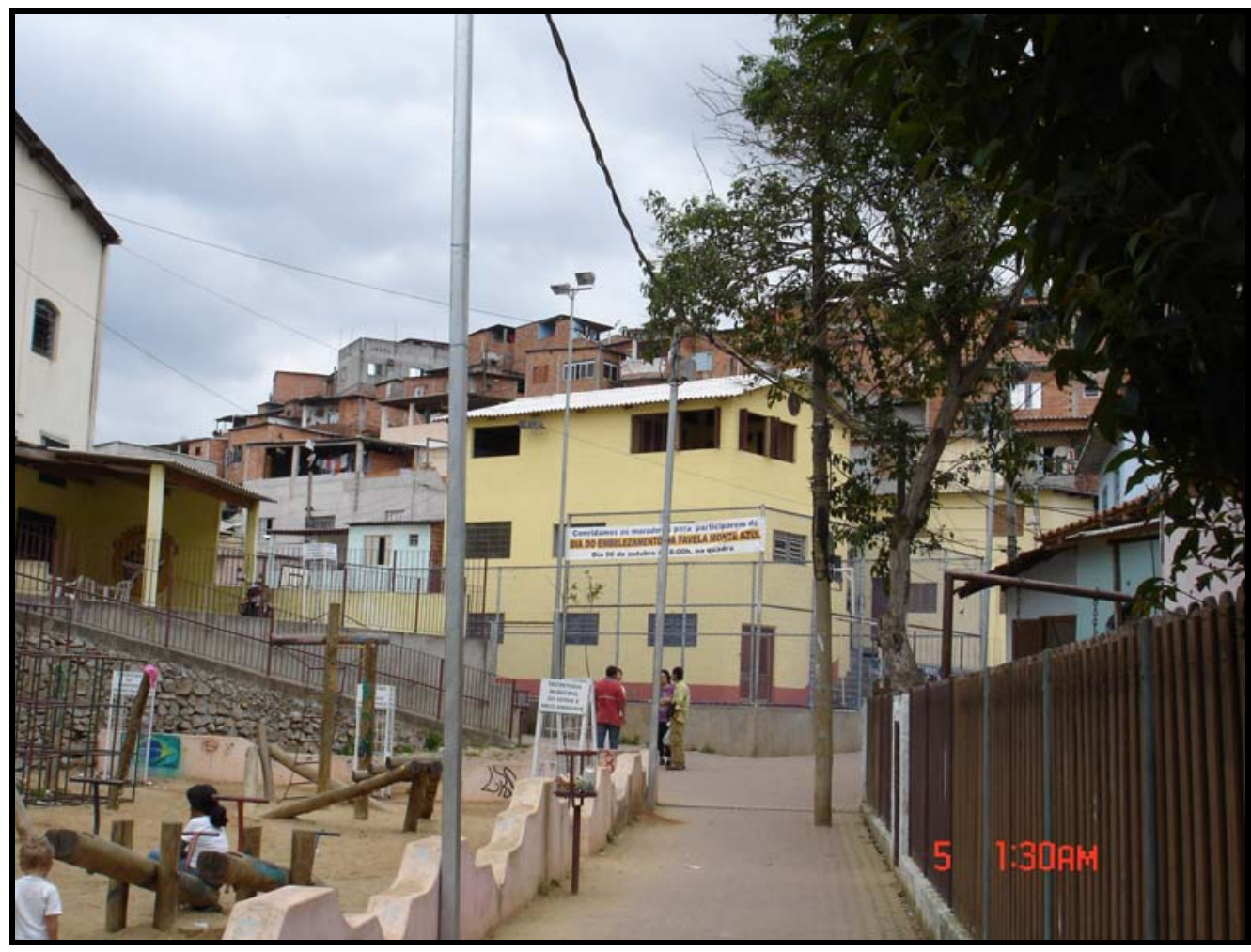

Foto 13: Ao fundo prédio da oficina de restauro e um grupo de voluntários estrangeiros. Nas laterais temos a presença das creches e do parque recreativo.

Autor: Ribeiro, F. V. Out/2006.

4 - Havia uma antiga casa para a oficina de restauro de imóveis localizada ao lado da quadra, que foi demolida dando espaço para um prédio de três pisos, ampliando a oficina e alguns outros trabalhos da ACMA. 


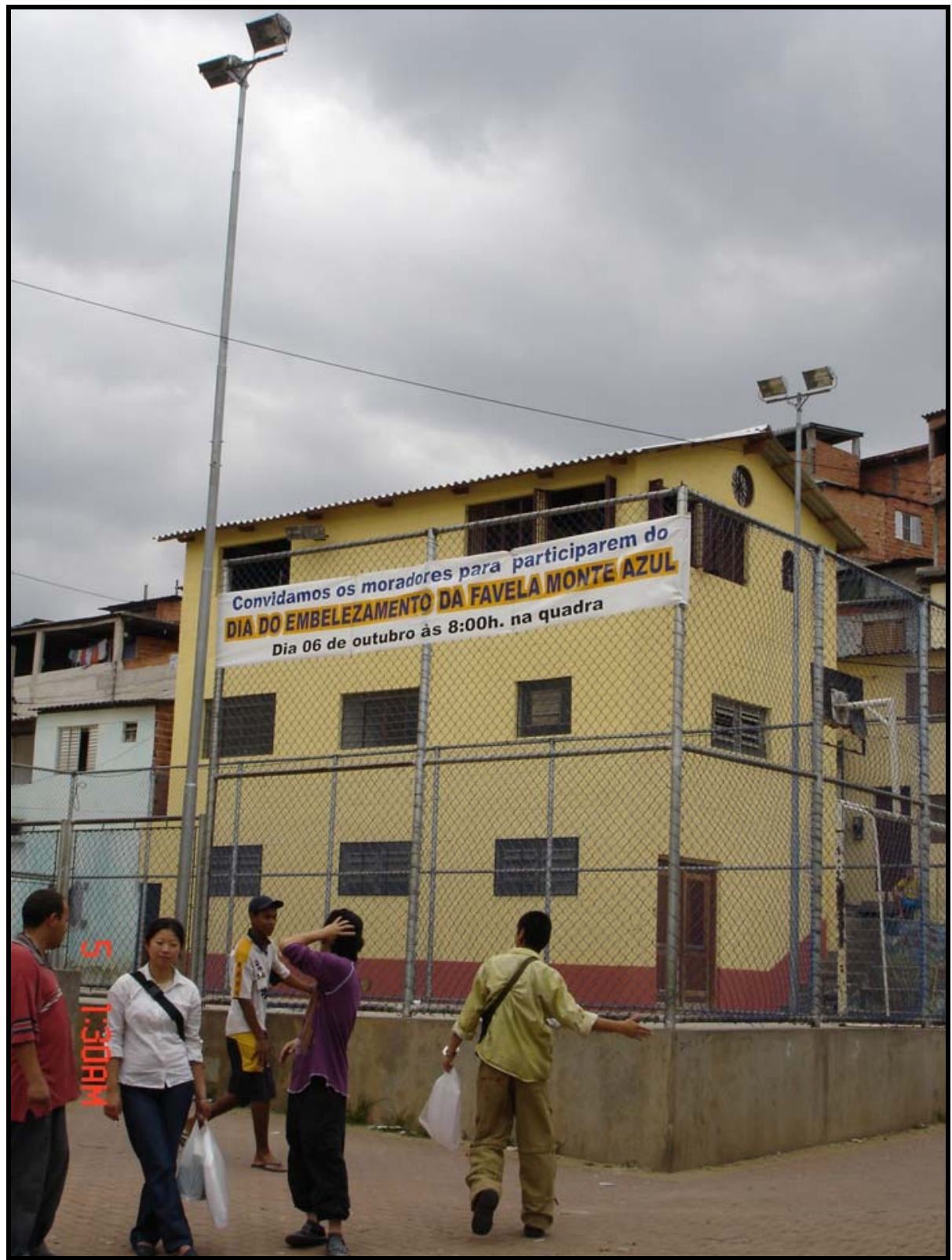

Foto 14: Prédio da Oficina de /Restauro de Móveis. Autor: Ribeiro, F. V. Out/2006 


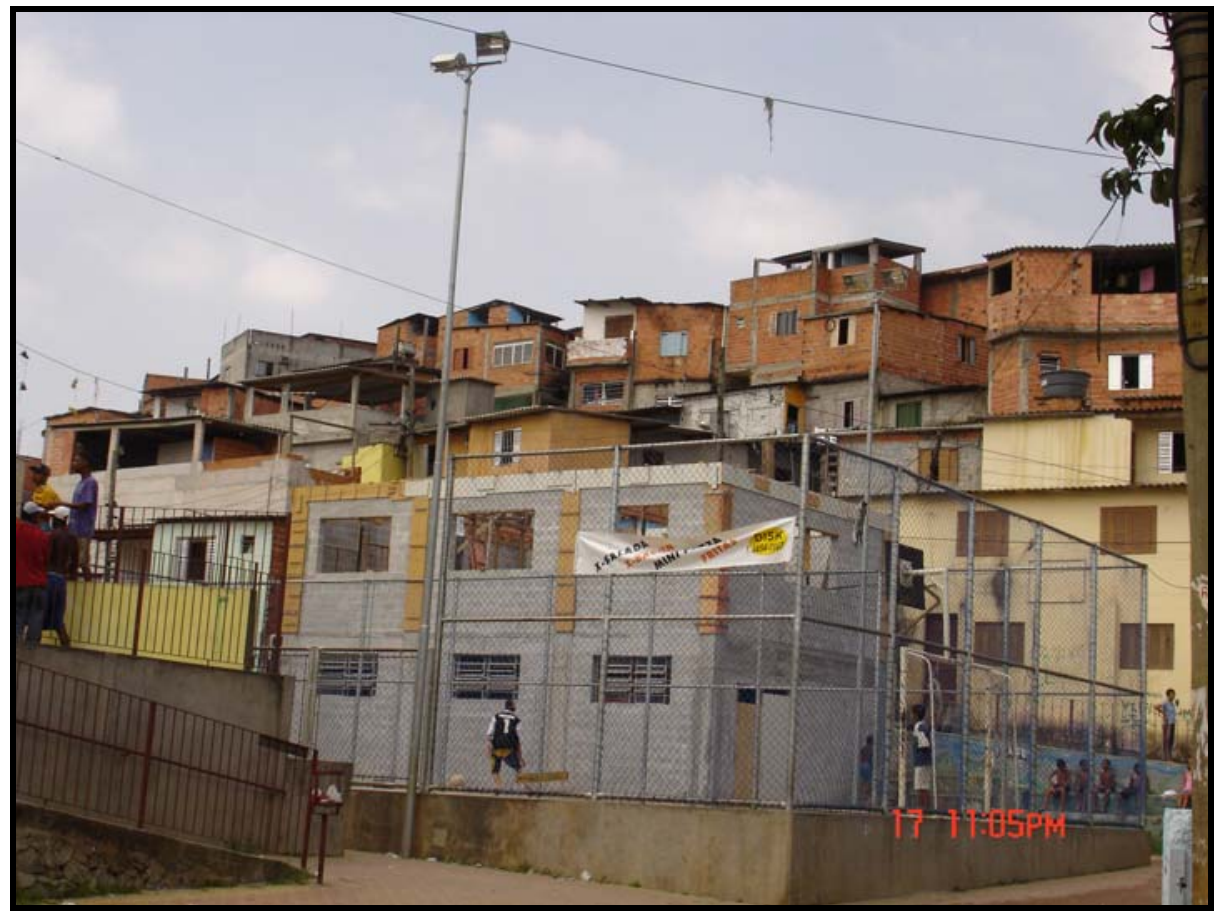

Foto 15: Ampliação do prédio da oficina de restauro de móveis. Autor: Ribeiro, F. V. Jan/2006

Sobre a infra-estrutura, um aspecto interessante a ser destacado é a inovação no sistema hidráulico. A partir dele há o aproveitamento das águas oriundas das nascentes existentes. Como é um fundo de vale que possui um número considerável de olhos d’água havia um risco as construções que estavam sendo produzidas afetando diretamente o projeto para construção do prédio. Para sanar tais problemas foram canalizados estas nascentes e a água represada serve as pessoas que freqüentam o prédio. Isto evitou que a água fosse diretamente a rede de esgoto, pois no processo de urbanização da favela a SABESP (Empresa de Serviço e Abastecimento do Estado de São Paulo) não autorizou a construção dos coletor tronco para separar a água das nascentes e advindas dos esgotos domésticos. 


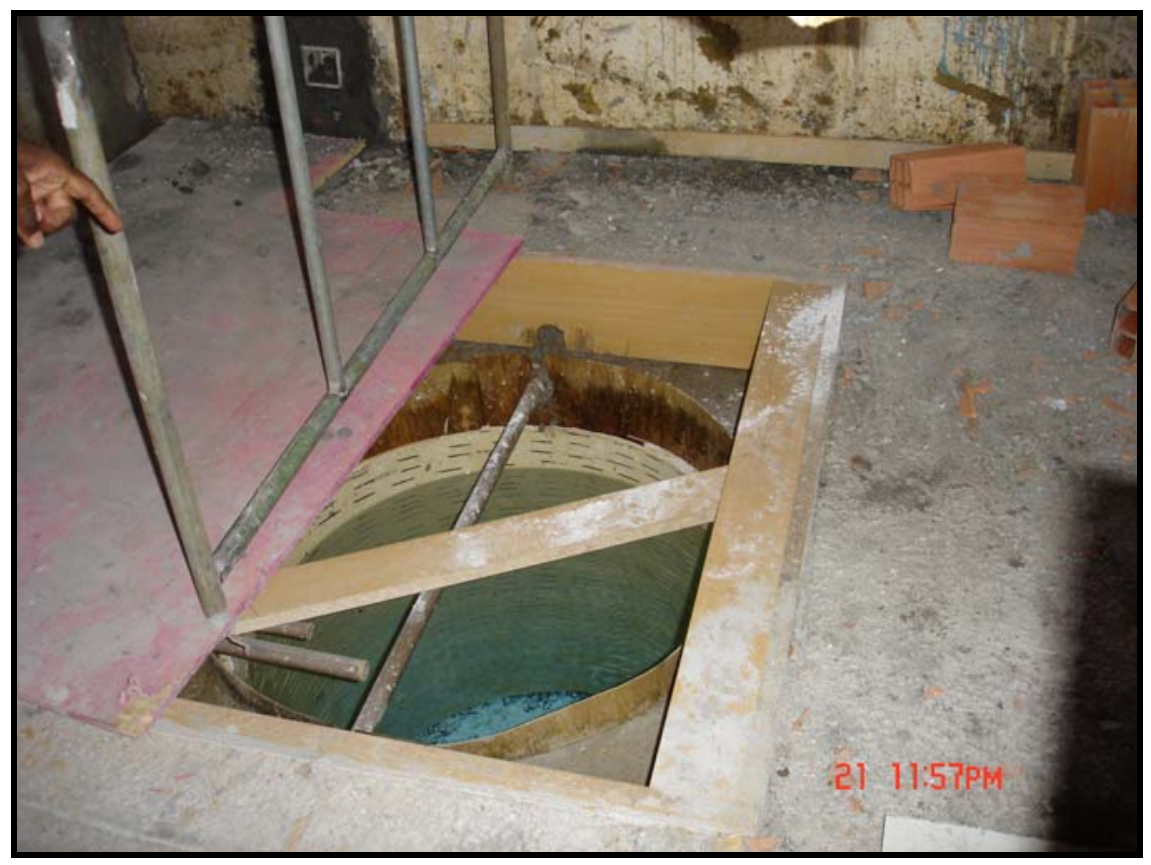

Foto 16: Sistema hidráulico de aproveitamento de águas oriundas das nascentes.

Autor: Ribeiro, F.V. Mar/2006

5 - Ao norte da favela, contíguo ao terreno da Eletropaulo e Petrobrás, existe a Casa Amarela, onde funciona a biblioteca formada por livros doados, na qual parte dos estudantes faz suas pesquisas escolares. Nela também há um espaço para os moradores realizarem festas (casamento, batizado, aniversário, etc), reuniões da comissão de moradores, e uma pequena academia de musculação, idéia da comissão de jovens.

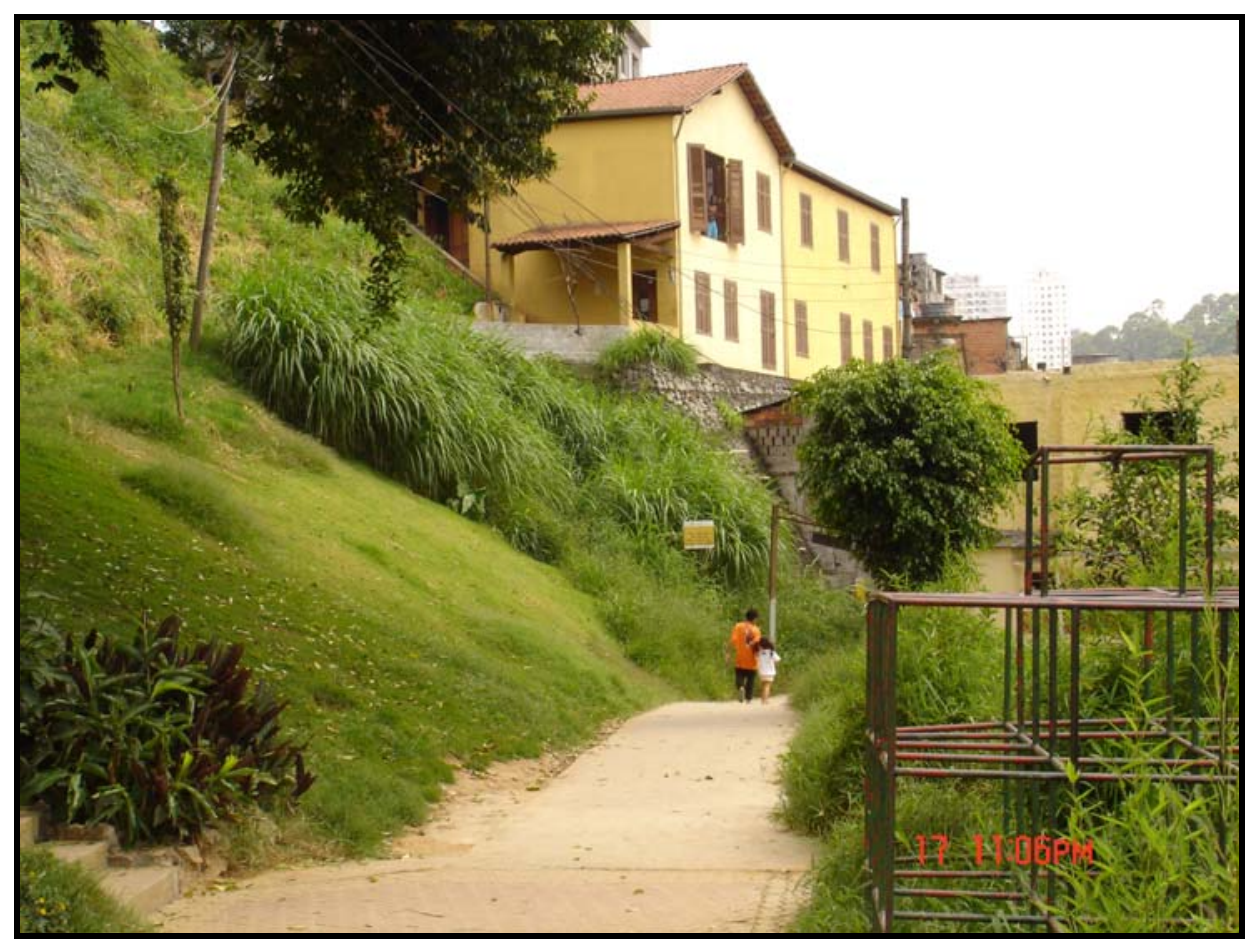

Foto 17: Casa Amarela onde há a biblioteca, salão de festas e academia de ginástica.

Autor: Ribeiro, F.V. Jan/2006 


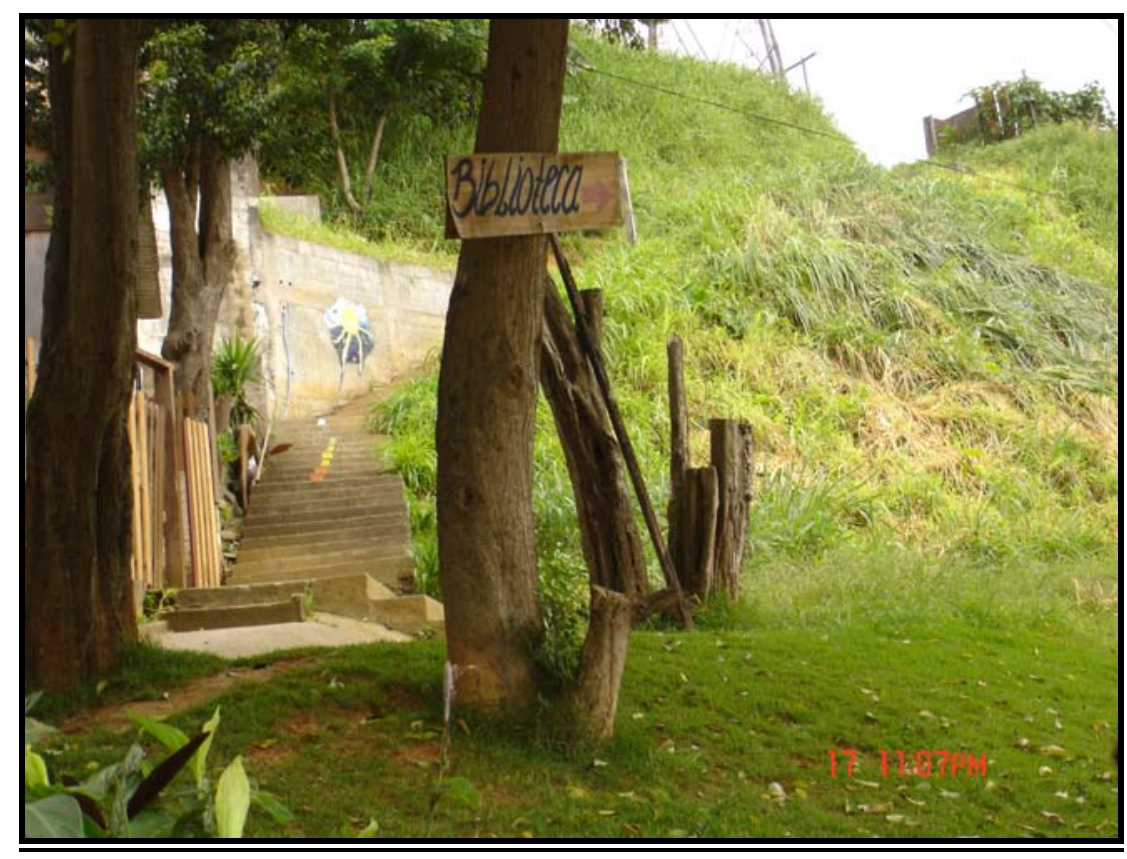

Foto 18: Indicação da Biblioteca existente na Casa Amarela. Autor: Ribeiro, F.V. Jan/2006.

\section{O Centro Cultural}

O Centro Cultural se localiza em área contígua à favela, num espaço cedido pela Prefeitura por um período de 90 anos às ações da ACMA. Na rua que dá acesso ao chamado Bairro Monte Azul (rua Tomás de Souza), onde se localiza o Centro Cultural, se caracteriza por um uso predominantemente residencial, com casas de padrão médio, muitas com 10 metros de testada e assobradadas, possuem acabamento externo bem feito, garagens com portões automáticos e nelas carros novos à vista. É este loteamento que até hoje se encontra em situação de irregularidade.

Nesta caminhada nos aproximamos da esquina do Centro Cultural, local que se diferencia na morfologia predominantemente residencial, por ter um muro que circunda todo o terreno. O acesso se realiza por um portão, que serve também de entrada aos carros pertencentes à Associação, e abre-se para uma grande quadra, que no decorrer do dia é usada por crianças e jovens em jogos de futebol, pega-pega, queimada, brincadeiras infantis de modo geral. Esta área na hora do almoço, café da tarde e jantar se transforma em refeitório ao ar livre. Este local, conforme depoimento da responsável pelo desenvolvimento institucional, é sempre preservada, mesmo com as necessidades 
de ampliação de espaços construídos, pois esta é a “...área onde as crianças brincam, eles não ficam dentro da sala de aula"26.

A disposição da construção é em “L”, tendo um segundo piso avarandado. É hoje em alvenaria, mas a construção inicial se fez em madeira (barracão), no qual se realizavam as atividades pedagógicas e de marcenaria reunindo as crianças e jovens da favela.

O uso das salas do prédio do Centro Cultural nos introduz ao desenho dos trabalhos realizados pela ACMA. Nele há a sala do núcleo de teatro, ao lado das salas do centro terapêutico - trabalho com jovens deficientes portadores da síndrome de dow - localizados logo na entrada da sede:

“O centro terapêutico é bem ali na portaria. Ali era uma igreja e o padre acabou mudando a igreja e a gente ficou com esse trabalho por causa das mães..."27

Na parte inferior do prédio há salas dedicadas aos trabalhos do núcleo sócioeducativo, a cozinha, as pias - nas quais cada membro (colaborador ou estudante) lava os objetos usados na hora das refeições -, banheiros, sala de administração, depósito de materiais e o teatro. Esta prática destaca uma maneira diferente de se relacionar com os trabalhos realizados, pois coloca a necessidade de cada um se responsabilizar pelas ações do dia-a-dia.

Há ainda o espaço do teatro, usado para as atividades culturais (mostras), encontros dos colaboradores e voluntários da ACMA nos seus dias de integração ${ }^{28}$, festas (junina, dia das mães e pais, etc), fórum de debates sobre temas específicos ${ }^{29}$, comemorações de aniversário da própria Associação.

O relevante, quando tratamos da morfologia enquanto condição primordial de aproximação ao nosso objeto de estudo, é compreendê-la como produto das relações tecidas naquele lugar e como estas estão permeadas por referenciais externos àquela localidade. Um equipamento como a sala de teatro, com esta série de atributos aqui

\footnotetext{
${ }^{26}$ Entrevista concedida em 08 e 15 de março de 2006.

${ }^{27}$ Depoimento Valéria Carrilho.

${ }^{28}$ Integração é a atividade realizada de 15 em 15 dias com os colaboradores dos três núcleos da Associação (Favela Monte Azul, Favela Peinha e Bairro Horizonte Azul). Este é o momento em que se debate e elabora a execução das ações da ACMA para reflexão do tema proposto para aquele ano.

${ }^{29}$ Em maio de 2005 foi realizado o primeiro Fórum de Teatro Monte Azul que objetivava debater as políticas públicas para a área, a importância da formação de grupos de teatro e as formas de integração dos grupos existentes. Dentre as atividades houve palestras ministradas pelo Sindicato de Artistas tematizando o papel do ator, Tin Urbinatti relacionando a cidadania e a prática do ator, apresentação de três espetáculos, um sarau e dois espaços de integração dos grupos.
} 
mencionados em nota, é muito raro. Ele se torna uma centralidade para os grupos culturais, ou mesmo de outros segmentos, pois amplia e dá uma possibilidade de multiplicidade de usos. É evidente que estes usos se realizam conforme normas daqueles gestores do espaço, todavia, a "brecha" das regras aumenta, relativizando a ação das transgressões.

Para dimensionar sua importância nesta região da metrópole é preciso verificar que para uma população de mais de meio milhão não há um teatro municipal. Os espaços de uso com esta função estão localizados depois do Rio Pinheiros, região de Santo Amaro. Estes espaços se ligam pelas vias de circulação, pertencentes ao complexo viário João Dias.

No Centro Cultural há também, no piso superior, as salas da recepção aos visitantes, da coordenação do desenvolvimento institucional, dos projetos, das finanças, da imprensa e do jurídico. É nele que funciona o "centro nervoso" das atividades "meios", como denomina Valéria Carrilho, isto é, aquelas atividades "suportes”, que viabilizam as ações de ponta da Associação. É por ele que se começa as visitas monitoradas. O centro cultural aparece como a porta de entrada aos trabalhos da ACMA, e lugar central das atividades que viabilizam, no plano das concepções (na logística), as normas de reprodução da Associação e seus moradores.

É esta morfologia da favela que revela e oculta, simultaneamente, sua produção e reprodução, seus conflitos e transgressões. Decompondo-a, construímos o movimento tendencial que perpassa a produção do espaço urbano paulistano revelando o movimento da vitória do valor-de-troca sobre o valor-de-uso.

É desta base material, produto do trabalho socializado e da apropriação privada, que podemos refletir sobre as determinações da urbanização crítica, que expropria o habitante da metrópole das possibilidades do urbano e o reduz a mero consumidor do espaço, bem como as estratégias que entram em contato com esta lógica.

Ao mesmo tempo que revela o movimento tendencial, também apresenta as particularidades deste lugar, que se diferencia em muitos aspectos das demais favelas datadas da década de 60. E são essas especificidades que nos propõe pensar sobre as insurgências à tendência, a qualidade diferenciada dos embates que resulta na territorialização dos sujeitos envolvidos, e como as normas "dos de fora", se tornaram “de dentro" se imbricando nos modos de uso do espaço da população.

O que nos deparamos, principalmente ao nos atentarmos à territorialização da ACMA e a descrição das suas atividades é a importância da presença deste sujeito na 
favela. Ele se encontra no centro da favela empregando seu espaço-tempo na vida cotidiana dos moradores.

Este conjunto de equipamentos e serviços promove uma imensa circulação de pessoas, sejam elas os moradores, os atendidos pelos serviços prestados, os voluntários estrangeiros e brasileiros, os visitantes, os fornecedores, imprimindo uma relação diferenciada na qual é regida predominantemente pelo ritmo da ACMA. Este ritmo se torna hegemônico pelo fato de ser próprio dos trabalhos ali executados, que carecem deste tipo de fluxo.

Para compreender os conflitos advindos destes espaço-tempos e de projetos diferenciados elegemos duas ações que acreditamos revelar as contradições aqui trabalhadas nesta territorialização da ACMA, são elas o processo de urbanização da favela e a atuação do núcleo teatral pertencente a própria Associação.

\section{A Política de "Urbanização" da Favela Monte Azul}

A aproximação com a morfologia da favela nos mostrou as melhorias infraestruturais conquistadas. Estas melhorias nos instigaram a compreender como decorreu o processo de “urbanização da favela” para a conquista deste espaço, primeiro por representar, do ponto de vista morfológico, uma resistência à degradação material da vida, e por outro, por reunir serviços que são escassos na periferia. Estes dois elementos conjugados poderiam revelar uma prática sócio-espacial calcada em resistências à tendência da degradação da vida na medida que desvelamos os usos de seus moradores.

Nessa direção, tentamos buscar o processo de participação da ACMA e da população na produção do lugar bem como os usos que atualmente estes sujeitos fazem deste espaço de uso. A pesquisa pôs a mostra as relações de dependência com a Associação Comunitária, que neste processo, ampliou sua territorialização no perímetro da favela ${ }^{30}$.Conforme íamos desenvolvendo o trabalho de campo verificamos que a Associação foi aquela que gerenciava a obra juntamente com uma liderança da favela.

A constatação do papel da ACMA na política de "urbanização de favela" transformou a orientação inicial da pesquisa, o que nos fez eleger a ONG como o foco neste processo, sem perder a articulação com os moradores da favela, pois esta é central, para alcançarmos os elementos da contradição entre apropriação e dominação do

\footnotetext{
${ }^{30}$ Um exemplo da ampliação de sua territorialização é a construção de um prédio de três patamares no centro da favela, como pode ser visto no conjunto de fotografias anexas.
} 
espaço. Isto é, o processo de “urbanização da favela” centrada nas ações da ACMA se tornou uma mediação para compreender as formas de territorialização de um sujeito como este, que possui a tendência de subordinação da população para a realização da reprodução das relações sociais de produção.

Todavia, a concepção do projeto de “urbanização de favela”, na qual se insere a Monte Azul, advêm das exigências dos movimentos sociais urbanos atrelados à reivindicação do direito à moradia, apontando desde o princípio um conflito entre concepções de projeto dos moradores e da instituição, principalmente no que se refere a participação e decisão do encaminhamento desta política.

A hipótese desta parte da pesquisa é que um projeto calcado nas reivindicações dos movimentos sociais urbanos de moradia, que possui como luta central o direito ao uso da terra urbana se revela neste lugar precarizada. E esta precarização nos aponta uma outra forma de degradação da vida. Ou seja, esta política reforça uma dominação do espaço, na medida que não transforma em um espaço de sociabilidade entre os moradores a ser apropriado para as experiências de politização dos mesmos, mas reproduz as relações assistencialistas e de dependência estabelecidas deste o princípio com a Associação Comunitária Monte Azul e a liderança da favela. Ao mesmo tempo, os benefícios infra-estruturais dados a população servem a ampliação e reprodução da ACMA.

A partir desta hipótese tentamos situar as políticas de ““urbanização de favelas”” e esboçar a intervenção realizada na Favela Monte Azul, colocando algumas idéias sobre a degradação da vida pela ótica dos processos de participação dos sujeitos implicados na produção destes lugares revelando o espaço enquanto condição, meio e produto.

\section{Favelas, Urbanização e Movimentos Sociais}

A “urbanização de favelas”, em sua origem, se introduz como estratégia de luta para a sobrevivência da população que se insere precariamente na lógica da cidade capitalista. À medida que avança a racionalidade produtivista sobre o espaço, transformando-o em condição e meio para a reprodução capitalista pela extensão da propriedade privada, há a produção da segregação sócio-espacial. É este processo que “empurra” a população de baixa renda para os locais em que não vigoram, no momento, as determinações da troca, como no caso os terrenos públicos em que se encontram 
grande parte das favelas, inclusive a Monte Azul. Ou então, há aquelas que se localizam em terrenos, que submetidos as leis do valor, são vendidos em um circuito informal, concretizando-se na precariedade do título de propriedade - um dos fatores de barateamento do preço do solo. O resultado pode ser visto na paisagem da metrópole, onde aparece os grandes aglomerados de casas auto-construídas e as concentrações de favelas.

Entretanto, tais áreas, que no momento ainda não representam atratividades para o circuito produtivo (do ponto de vista formal) na totalidade da metrópole, aparecem como potenciais para o processo de valorização e integração ao espaço produtivo no circuito formal. A periferia, de tal forma, é compreendida como espaço que apresenta potência de valorização (ou sobre valorização) ao mercado imobiliário.

Quando ela deixa de ser potência e começa a ser cobiçada por inúmeros mecanismos de valorização, os processos de expulsão da população se reatualizam. É neste momento que a "urbanização de favelas" se torna uma resistência à segregação sócio-espacial, pois seria uma forma de questionar as políticas de remoção de favelas atreladas ao circuito do mercado imobiliário e lutar pelo acesso á terra urbana. Ela aparece enquanto resistência a tendência da sobreposição do valor-de-troca sobre o valor-de-uso.

As políticas de remoção de favelas ficaram mais explícitas na produção do espaço carioca (Rio de Janeiro), mas em São Paulo tal política também era uma norma. Quando os espaços de potência de valorização se tornaram objeto de valorização, o procedimento de expulsão dos moradores se fazia mediante indenização ${ }^{31}$, dispersando a população da favela pela cidade, e se transformando inclusive em outras favelas ${ }^{32}$, ampliando ainda mais o tecido da habitação precária na metrópole e reproduzindo as relações sociais de produção.

Mas as estratégias e ações dos movimentos sociais aparecem em um movimento de contestação das perdas da possibilidade do uso e acesso a terra urbana bem como reivindicação da apropriação do espaço urbano. Na perspectiva da reprodução da vida, denunciam as degradações da vida urbana, os elementos da "nova pobreza", a

\footnotetext{
${ }^{31}$ O exemplo recente de processo de expulsão da população favelada foi a da Favela das Águas Espraiadas. Sua expulsão abriu espaço para a continuação da produção da Av. Berrine como eixo do setor terciário moderno, dando lugar aos prédios de maior tecnologia no espaço paulistano, integrando-se a rede mundial de cidades. Os trabalhos que fazem referência a este processo são os FIX, M. e de ALFREDO, A.

${ }^{32}$ Denaldi, Rosana, "Políticas de urbanização de favelas: Evolução e Impasses” doutorado FAU-USP, São Paulo, 2003.
} 
impossibilidade do uso, o modo como vigora a propriedade privada da terra e as ações segregacionistas do Estado na efetivação das urbanizações das favelas, revelando os conflitos no/do espaço urbano. Porém, muitas estratégias objetivavam somente as intervenções pontuais das políticas de urbanização, fragilizando o projeto dos movimentos e suas potencialidades de questionamento dos interditos dados pela racionalidade da reprodução do capital, como o que percebemos na Favela Monte Azul.

Em São Paulo, há um grande destaque destas políticas públicas no período do governo Luiza Erundina (1989/1992). Em relação as urbanizações de favelas percebemos a maior possibilidade de incursões das estratégias e táticas dos movimentos sociais na área habitacional.

Neste período, houve uma ampliação dos recursos que focou a construção de unidades habitacionais e a "urbanização de favelas” por meio de mutirões, culminando no processo de regularização fundiária como ocorreu na Favela Monte Azul. Os recursos eram oriundos do FUNAPS ${ }^{33}$ (Fundo de Atendimento à População Moradora em Habitação Sub-Normal) e seu caráter de dotação orçamentária era a fundo perdido.

No caso da “urbanização de favelas” em São Paulo, este recurso do FUNAPS foi ampliado nos programas Funaps-Favela e Urbanacom, este último utilizado no processo da Favela Monte Azul. Do ponto de vista da organização estatal, houve também uma reestruturação interna na organização dos técnicos da Prefeitura alargando a estrutura da Secretaria de Habitação e impedindo, “em parte”, a entrada de gerenciadoras, que implica no aumento de custos e entrada do projeto na lógica produtivista. Este "em parte” se destaca, pois a Prefeitura ao tentar abrir concursos para suprir as necessidades da nova estruturação foi impedida pelo Legislativo. A solução, então, foi contratar equipes técnicas, mas com uma ressalva - todo o processo seria gerenciado pelo HAB (Superintendência de Habitação Popular), diferente do que seria instituído nas gestões subseqüentes.

A estrutura se desenhou da seguinte forma: interna a Secretaria de Habitação retorna o HAB, responsável pelas habitações de interesse social, que anteriormente, pertencia à Secretaria de Bem Estar Social. Nesta transferência se regionaliza e descentraliza as decisões e ações passando a escritórios regionalizados no município, facilitando a participação popular e garantindo a agilidade nos processos. Em 1990,

33 “Com dotação orçamentária a fundo perdido para atender individualmente às famílias: na aquisição do terreno, compra de material de construção e reconstrução de barracos em situações emergenciais. (...) Subsidiaria também parte do valor de aquisição de casas da Cohab-SP, para famílias que precisavam ser removidas para execução de obras.” Rodrigues, A.M.(1988). 
organiza-se o GEU - Favelas (Grupo Executivo de "urbanização de favelas”) com o intuito de elaborar e executar as políticas de "urbanização de favelas" com participação popular.

Adota-se critérios para selecionar as prioridades, dentre elas se expressa uma central para os movimentos sociais: dar prioridade aqueles núcleos que estejam organizados. Tal medida era necessária, pois na execução de um projeto tinha-se a idéia de construir um espaço de experiências de politização a partir do trabalho em mutirão.

Os mutirões ${ }^{34}$ tiveram papel central, principalmente pelo fato de representar a conquista de anos de luta dos movimentos, e em certo sentido, assegurando o acesso a terra urbana na medida que diminuía os custos. Esta questão é de difícil equacionamento, porque os mutirões englobam a dimensão do sobre-trabalho dos habitantes da cidade, caracterizando-se também como uma forma de exploração, isto é, a conquista ao direito à terra urbana só é possível mediante os ônus de exploração sobre o trabalhador.

Mesmo com tais problemas estas experiências poderiam ser apreendidas como oportunidades de organização popular, ou a forma possível de resistência produzida diante o império da propriedade privada. Todavia, seus limites são apontados a partir da constatação que os moradores das favelas, no governo subseqüente, tiveram suas ações desmanteladas.

Porém, cabe ressaltar as conquistas desta fase:

“No final de 1992, haviam sido entregues cerca de 7.200 unidades por mutirão e 3.900 unidades por empreiteira. No término do governo, cerca de 6.500 unidades se encontravam em andamento, 5.184 por mutirão e 1.293 de provisão em favelas.” Nos projetos relacionados à "urbanização de favelas” “O programa atuou em 91 favelas com obras e intervenção integrada, sendo que 22 foram concluídas até o final da gestão (17 obras de infra-estrutura), envolvendo cerca de 6.100 famílias. "35

Na gestão Maluf e Pitta, governos subseqüentes, a política de “urbanização de favelas” se transforma por completo, articulando-se aos interesses de grandes

\footnotetext{
34 "Mas para os movimentos organizados não se pode falar de auto-construção e sim de mutirão: um processo de trabalho conjunto, que é considerado uma forma de organização, de discussão de problemas e de avanço para solucionar os problemas de moradia. E também uma forma de contestar as empresas de construção civil que fazem encarecer a produção da habitação.” Rodrigues, A.M. (1988) pp.183.

${ }^{35}$ Ibidem
} 
empreiteiras e consultorias de engenharia, que agora se inseririam como sujeitos principais de elaboração dos fundamentos desta política pública.

As verbas dos mutirões são paralisadas segundo alegação de irregularidades em contas, que anos mais tarde, se verificou não existir. O Funaps é substituído pelo Fundo Municipal de Habitação e o gerenciamento dos projetos é passado de HAB para a COHAB-SP retirando seu caráter descentralizado.

Em relação ao Fundo Municipal de Habitação (instituído no ano de 1993 pelo então prefeito Paulo Maluf), que era uma reivindicação dos movimentos para a conquista de recursos para a habitação popular, é aprovado com limitações que inviabilizam o projeto quisto por eles. Este fundo, que comporta também um conselho, objetivava, em tese, realizar a avaliação das prioridades de investimentos dos recursos em habitação popular (forma de participação na gestão da cidade), mas se materializou na negação do poder de intervenção sobre as políticas habitacionais. Isto é, a configuração dada a ele é de não vinculação orçamentária restringindo os recursos às sobras do orçamento, que significou uma redução nos investimentos na área. Em termos de continuidade da política habitacional, estes recursos somente se dirigiriam as obras de infra-estrutura e não na intervenção sobre a habitação. O Fundo Municipal de Habitação, que financiaria as urbanizações de favelas e a política habitacional de caráter popular no município, se estrutura inviabilizando seu objetivo principal,ou seja, a reorientação de recursos para as populações mais carentes.

A avaliação de Marques e Saraiva aponta que em 1996 o fundo recebe um novo golpe semelhante ao do BNH (Banco Nacional de Habitação), pois há uma ampliação da faixa de renda da população que seria atendida por estes parcos recursos, isto é, de cinco salários mínimos se alarga para dez, representando a perpetuação do direcionamento dos recursos à classe média.

No presente, a “urbanização de favelas” carrega em si a contradição uso-troca. Se por um lado ela continua enquanto "bandeira” dos movimentos sociais urbanos, conjuntamente com a regularização fundiária, a sua institucionalização na década de 90 permite introduzi-la aos mecanismos da urbanização como setor produtivo, regida por normas de cunho internacional. A concepção das políticas de "urbanização de favelas” se torna "globalizada" sob a lógica do Banco Mundial e do Banco Interamericano de Desenvolvimento.

O governo Marta Suplicy ao mesmo tempo que financia as "urbanizações de favelas” do período Luiza Erundina inicia novos projetos com a lógica destes agentes 
internacionais, evidenciando a justaposição de concepções de políticas públicas contraditórias. Ao pontuarmos o perfil das novas políticas de "urbanização de favelas" no presente localizamos o processo, ainda em curso, da Favela Monte Azul enquanto uma resistência aos novos ditames postos pelo Estado na totalidade da metrópole.

Cabe mencionar a característica das novas políticas de urbanização para contrapor ao que esta sendo executada na favela Monte Azul, para situarmos a sua condição de relativa resistência ao processo geral.

Este governo já estava profundamente inserido na trama dos procedimentos exigidos nas políticas públicas. Ao verificar a configuração dos contratos e convênios das urbanizações de favelas deste período - das poucas que se iniciaram no período - o que demonstra é uma série de clausulas de âmbito internacional, já que parte dos financiamentos provinham do Banco Mundial e do Banco Interamericano de Desenvolvimento. Dentre elas há duas em especial que nos apresentam, em síntese, a “urbanização de favelas” tornada negócio pelos órgãos financiadores: a primeira corresponde a contratação de empreiteiras de renome para a realização das obras. Isto significa, em sentido amplo, a recusa de um dos alicerces da organização dos movimentos de habitação, que é o processo de mutirão. Em segundo, há a exigência de contratação de gerenciadoras do projeto e da obra chamadas de Consultoras de Engenharia. Ao contrário do que os movimentos propunham, elas produzem o projeto com o mínimo de participação popular, que pode acarretar, na prática, num maior número de barracos a ser removidos, por exemplo.

Segundo estudo de Flávia Silva (2006) sobre a "urbanização de favelas" articulada à Operação Urbana na zona oeste de São Paulo, esta política fragmenta-se entre o projeto e a obra, cisão que era evitada pelos movimentos sociais por meio das formas de participação dos moradores da favela, mesmo que se realizassem precariamente.

Esta cisão aparece como necessária a realização desta política pública como negócio, pois na obtenção da otimização dos rendimentos investidos, o tempo da participação da população ou a margem de negociação entre os empreendedores e os moradores deve ser o mínimo. Este mínimo tempo faz parte também das exigências postas pelo Banco Mundial ou Banco Interamericano de Desenvolvimento (BID) traduzidas como Eficiência.

No balanço deste governo, não podemos deixar de mencionar que há a execução dos projetos de "urbanização de favelas", que se arrastavam deste o governo Luiza 
Erundina. Os projetos que se alicerçam em fundamentos mais próximos das exigências dos movimentos sociais. O que importa compreender é que a continuação desta política se realizou lentamente com continuas paralisações de verbas.

É na transição da hegemonia do uso, como caráter da "urbanização de favelas" para os movimentos sociais, para a cooptação dela para a realização da troca, nas normas atuais deste política, que destacaremos a experiência da Favela Monte Azul localizada na zona sul de São Paulo, que a partir de 1993 tem seus recursos paralisados, dificultando o trabalho de mutirão.

\section{A Favela Monte Azul e o Processo de "Urbanização da Favela"}

É no lugar que apreendemos as potencialidades, mesmo que limitadas pela natureza estatal, de uma política pública ainda referendada nos projetos de possibilidade de uso da cidade pelos seus habitantes.

A política de urbanização da Favela Monte Azul se inicia na concepção da política do governo Luiza Erundina, que como já foi mencionado, possui um caráter que se aproxima das reivindicações dos movimentos sociais. Desse modo, é a partir desta conquista que se transforma radicalmente a morfologia da favela, instituindo novas práticas sócio-espaciais, permitindo usos, que na maioria das vezes são restritos ao restante da metrópole. Mas, tais positividades são incorporadas ao processo perversamente, porque aprofunda a territorialização da ACMA conforme a coordenação que esta faz do processo de urbanização ratificando as relações assistencialista no lugar.

\section{A Atuação da Associação Comunitária Monte Azul nas Intervenções na Favela}

A inserção dos alemães antroposóficos marca o período de intervenção na favela. Eles orientam a vida dos moradores, seja para organizá-los para participar dos movimentos sociais na época, seja para mobilizá-los nos mutirões. Enquanto mediadores das empresas privadas como do poder público, vão integrando a população ao seu trabalho por meio da doação de madeiras para melhorias dos barracos, ou da doação de cestas básicas ou remédios às famílias mais carentes. Os trabalhos da 
Associação se ampliavam na medida que se articulava com os setores privado e público $^{36}$.

O depoimento do coordenador do núcleo de teatro nos mostra a inclusão dos primeiros trabalhos da ACMA com a participação fundamental de D. Ute, e as articulações que se concretizaram entre os favelados e os sujeitos externos à favela denotando as bases de introdução no lugar das relações assistencialistas,

“E ai a gente começou a procurar onde essas crianças moram[referindo-se as crianças que freqüentavam sua casa], e ai a gente descobriu que era na Favela Monte Azul, era bem precária, com poucas casas, muito mato, não tinha água, nem esgoto, nem luz. Não tinha nada. Era uma pobreza. As pessoas tinham vindo de Minas e Pernambuco. As pessoas que não tinham onde morar vinham procurar esse lugar aqui. Achava um cantinho para fazer seu barraco com caixotes, plástico. Era muito precário, e a gente viu que eram pessoas que precisavam muito de ajuda. Começamos a entrar, eu e a Ute, visitar as pessoas, conversar com eles, quais eram as necessidades deles. Então, a necessidade se via com [a constatação de] muitos vermes, os dentes estragados, era fome, era muita pobreza mesmo. Qual era a coisa que tínhamos que fazer de começo, era trazer essas crianças. Vê se a gente conseguia alimentos para pelo menos fazê-las almoçar, fazer atividades artísticas, amenizar um pouco o sofrimento deles, o que a Ute sempre fala é que não é só o alimento de comer, muitas vezes, precisa de outro alimento que é o alimento espiritual, também ajuda. E ai a gente pensava que eles também precisariam de amor, carinho, compreensão, já que os pais estão desesperados, muitas grávidas com muitos filhos, sem emprego. Ai começaram a chegar as pessoas, o Paulo e a Renati, e ai as reuniões não eram mais em dois mas em dez [todos pais dos alunos da Escola Rudolf Steiner, baseados na antroposofia]. Ai a gente começou a ver essa questão da saúde. Ai conhecemos o Michel que estava estudando medicina ainda, mas ele já achava que dava para ajudar. Ai com a favela construímos um barracão, foi o primeiro ambulatório, bem precário, todos os remédios eram doados,

\footnotetext{
${ }^{36}$ Valéria Carrilho nos diz "O trabalho da Associação se fortaleceu quando a Ute começou a buscar recursos. Batalhou muito em prefeituras atrás de verbas. Ela teve a oportunidade de ir para a Alemanha e proferiu algumas palestras, data daí a captação de recursos internacionais, e depois de algum tempo ela recebe uma verba de doação proveniente da Alemanha.”
} 
e assim a gente começou a trabalhar essa questão da saúde. Minha irmã era enfermeira e começou a ir nas casas, fazer o levantamento, começamos a juntar alguns moradores em algumas reuniões para ver o que precisava melhorar, indo na Prefeitura para ver a luz, arrumar os barracos ainda melhor, depois arrumar as vielas. A gente escorregava ali. Tudo era muito liso, e fomos vendo a questão da água, ai foram melhorando, as pessoas se animando mais, e isso foi crescendo e a favela foi crescendo, o trabalho a cada dia passava necessidade, aumentava. Então, essa questão da água, da luz, depois veio a questão da mãe, como ela dar a luz. Veio a Ângela, começou a trabalhar a questão da parteira e da mãe, como se prevenir, valorizar o parto natural, e ai foi um processo de conscientização. O trabalho foi crescendo, os alunos chegando e teve a necessidade de uma padaria, de uma marcenaria, tudo se começava pequenininho, a marcenaria começou com o Paulo [hoje coordenador da área de urbanização], tudo muito manual, o serrote, com o martelo. Projeto $e$ padrinhos da Alemanha que apadrinhava as crianças. Ainda não tinha projeto com a Prefeitura, depois de alguns anos é que veio as pessoas mais empreendedoras com essa coisa de projetos com a Prefeitura para as creches. .[grifos meu] Os projetos foram aparecendo, e hoje o projeto com a Prefeitura nos ajuda muito com alimentação básica”.

Um outro depoimento dado por um dos moradores nos fornece elementos das relações de dependência que se formavam entre moradores e ACMA, conforme as articulações desta última com empresas:

“A D. Ute tinha ganhado muita madeira da VolksWagem [empresa alemã] e deu para construir o barraco melhor, porque era muito pequeno. Me deu um punhado de madeira e fiz um barraco bem grande sem divisão nem nada. Também a gente não tinha luz, não tinha água, não tinha nada. A luz que tinha era emprestada, pagava um preço absurdo, mas você acendia a lâmpada e não enxergava nada dentro de casa, precisava duma vela para procurar alguma coisa.(...) Depois que a Ute apareceu aqui as coisas ficaram mil maravilhas. (...) A população ajudou, era mutirão quase todo o sábado, depois arrumou cesta básica para gente, e ai o pessoal ajudava mesmo. Era o pessoal fazendo mutirão, era uma festa." 
Os moradores, por impulso dos novos sujeitos que entravam no lugar de sua moradia, como podemos notar na fala de Cido e Tião, iniciam suas participações em ações articuladas aos movimentos sociais urbanos, organizados desde a década de 70 , reivindicando água e luz, que chegara nos anos 1980, tendo predominantemente, a supervisão da ACMA, que lançava os alicerces das relações assistencialistas, perpetuadas até hoje.

A história da melhoria infra-estrutural se inicia no período de produção das relações entre os moradores e a Associação Comunitária. Logo nos anos 80, começando em 1983, temos a execução de pavimentação de vielas e construção de escadarias por meio de mutirão. Em seguida, nos anos de 1985 e 1986, há a implantação da rede elétrica e abastecimento de água, respectivamente pelos programas Pró-Luz e Pró-Água nas vielas principais.

Em depoimentos de moradores que participaram dos mutirões nesta fase, nos relataram que a luta por estas melhorias era incentivada e mesmo, acompanhada por membros da Associação denotando a atuação da ACMA na organização dos moradores.

“A favela não tinha luz, a gente começou a brigar por luz e água. A gente brigava e a Associação tinha algumas pessoas que trabalhavam na Associação e envolvia com a gente. Depois começou a entrar Seu Paulo, entrar o pessoal para ajudar a fazer isso. A gente andou muito. (...)

A gente ia na Prefeitura, a gente ia na Eletropaulo a gente ia por todo o canto. E é assim, você chamava as pessoas para ir com você e ninguém ia, diziam vou nada, se vier coisa pra você vem pra gente também. A Julieta da Associação [não moradora] ia com a gente por todo o canto, todo canto que a gente ia, ela ia atrás(...) Até que um dia sem ninguém esperar chega um puta de um carrão carregando poste. Todo mundo foi carregar os postes. Passou quinze dias e tudo mundo tinha luz, graças a Deus. A água também foi mesma coisa, correu, correu, correu, até nós conseguir também.”

Nesta fase de produção, já existia dentro da favela os barracões construídos por sistema de mutirão (pode ser visto na fotografia $n^{0}$ ??? capitulo 1), onde abrigava os serviços de saúde, como também, segundo conversa com um ex-membro da Associação, funcionava como um atendimento as necessidades da população, recebendo as demandas e aprofundando os laços de dependência e assistencialismo. 
Dentre as conquistas, também destacamos no ano de 1990, o encaminhamento a Câmara Municipal do pedido de desafetação da área para fins de regularização fundiária (concessão de direito real de uso), que foi em 1993 decretada a título precário, isto é, permissão de uso.

Como posto anteriormente, ela se assentou em duas destas áreas pertencentes a loteamentos que no período, década de 60, não haviam sido aprovados, mas foram comercializados. O loteamento que abrange a R. Vitalina Grassmann foi aprovado somente no início da década de 80 , porém, o segundo, que se encontra ao lado oposto a este, ao longo da Avenida Tomas de Sousa e R. Joaquim Dias, até o momento não está regularizado, e seu processo extraviado. São as áreas de uso comum, portanto, que foi ocupada e deu origem à Favela Monte Azul, por isso, a necessidade do processo de desafetação.

Atualmente, ela é considerada uma zona especial de interesse social (ZEIS) e parte de sua extensão se encontra em uma zona considerada de uso industrial (porção norte à área pertencente a Eletropaulo) e ao sul zona de uso misto.

Em relação à “urbanização da favela”, esta atravessará os momentos de produção e reprodução da favela Monte Azul sofrendo diretamente os impactos das intervenções dos governos seguintes. Pois o convênio é assinado no último ano de gestão Erundina e suas contas em 1993 são bloqueadas para averiguação. Isto significou o prolongamento da obra até o ano de 2006, última previsão de conclusão.

A conquista desta intervenção não se efetivou conforme as demais favelas que fizeram parte desta política realizada no período. O motivo de sua entrada no programa se deve a um acidente ocorrido devido às chuvas em São Paulo, que desencadeiou um processo de escorregamento redundando na morte de uma criança. Tal fato foi objeto político nas mãos da imprensa provocando a ordem, diretamente do Gabinete da Prefeita, de introduzir esta favela nos programas de urbanização. Seu Paulo descreve a conquista:

“E foi ai, no início dos anos 90, na gestão da Luiza Erundina, tinha todo um movimento em São Paulo de luta por moradia e de melhoria nas comunidades. E ai o Monte Azul também fez parte disso. Essa comissão de moradores participou desses movimentos, manifestações e tal. E nessa época, então, surgiu esse projeto de "urbanização de favelas” em São Paulo na gestão da Luiza Erundina. E com a participação dessa comissão de moradores, que surgiu essa idéia de fazer uma urbanização da favela. 
Justamente porque na época aconteceu uma tragédia aqui, porque onde hoje é a biblioteca tinha um barraco lá, que numa das chuvas teve um deslizamento ai caiu e matou uma criança. Ai isso na época teve uma repercussão na imprensa muito grande, a Folha de São Paulo veio aqui. E a gente falou de tudo que a gente tinha pedido pra Prefeitura, e que, infelizmente, não acontecia nada. Bom, isso já foi uma força já muito grande pra despertar a Prefeitura. E foi daí que começou esse movimento, foi cada vez mais forte e se chegou ao ponto, depois de muitas idas na HAB, que é na Secretaria de Habitação, surgiu essa idéia de fazer a urbanização, e realmente foi incluído nesse programa de São Paulo como um todo"37.

O programa que se refere Seu Paulo foi o Urbanacom. Este programa se caracterizava pela construção de infra-estrutura por meio de mutirão. Seu convênio era firmado junto a Associação de Moradores, uma Assessoria Técnica inscrita na Prefeitura e a HAB. A gestão e execução da obra ficariam a cargo da associação dos mutirantes. ${ }^{38}$

No caso da Favela Monte Azul, o convênio (anexo) foi assinado pela Associação Comunitária Monte Azul - que não representa moradores -, Comissão de Moradores que não tinha status jurídico, a Assessoria Profissional de Apoio ao Movimento Popular e a Prefeitura. Porém, na medida que se paralisou as verbas, parte dos moradores deixaram de participar e a comissão de moradores se desmobilizou, ficando a continuidade do projeto a cargo da Associação, que prosseguiu no gerenciamento e prestação de contas da urbanização ${ }^{39}$.

No princípio, o primeiro passo foi a elaboração conjunta com os moradores do projeto da favela, que estavam sendo coordenados pela Assessoria Técnica. Contudo, para a realização do projeto a Associação faz o trabalho de articulação da comissão de moradores para auxiliar na organização e convocação dos moradores. Um dos membros da ACMA auxilia na estruturação da comissão de moradores para que pudessem organizar os representantes dos setores e das vielas para o encaminhamento dos trabalhos.

\footnotetext{
${ }^{37}$ Entrevista concedida em 22 de fevereiro de 2006, por Seu Paulo. Membro da Associação Comunitária Monte Azul e representante da área de urbanização da favela.

${ }^{38}$ D’Alessandro, Maria Lucia Salum, Avaliação da Política de "urbanização de favelas” em São Paulo no período de 1989/1992, dissertação de mestrado, Fundação Getúlio Vargas, São Paulo, 1999.

${ }^{39}$ Em documentos mais recentes não há a assinatura dos representantes da comissão de moradores como posto no contrato firmado no ano de 1992, levando-nos a considerar que o processo de urbanização ficou sob responsabilidade da Associação Comunitária Monte Azul.
} 
Essa organização se pautava pela articulação entre a ACMA e a liderança da favela. Este último exerce um papel importante internamente à favela até o ano de 2007. Isto nos leva a perceber que somada as relações de poder da ACMA havia também relações desta ordem exercidas por uma figura entre os moradores revelando que as relações assistencialistas também se construíam nos limites das relações entre os moradores. Este exercício de poder se apreende nas decisões obtidas no processo de urbanização: a própria Associação juntamente com a liderança da favela escolhiam os trabalhadores que fariam parte da equipe permanente da urbanização. Estas ações foram reforçando as relações de dependência, pois a população não se inseria no processo com autonomia, mas as decisões eram tomadas muitas vezes, pela Associação articulada à liderança da favela.

O projeto de intervenção elaborado no ano de 1993 se resumia a melhoria nas vielas e na contenção dos taludes a partir da construção de muros de arrimo. E a canalização do córrego se incorporou apenas no período dos anos 2000. Ainda nos anos 90, o plano traçado para a área central da favela era a construção de uma praça, para que continuasse a ser um espaço de uso.

A arquiteta responsável nos disse em depoimento que

“A gente não tinha nenhuma condição de canalizar o córrego, mas a gente já pensou desde o princípio em fazer uma praça ali, porque ali era ponto onde as pessoas vinham para as creches, as crianças iam para as creches, as creches se concentravam ali. Já tinha o ambulatório, não daquele tamanho, teve ampliação. Já tinha a padaria, já tinha a oficina de marcenaria, tinha uma lojinha muito precária. Hoje é algo sofisticado. E eles tinham as oficinas de reciclagem de papel que eles mantêm. Depois já na gestão Marta, eles conseguiram o centro de informática. (...) Aquele espaço já era público. Já era espaço de lazer, porque enquanto as mães lavavam as roupas de suas casas ali, as crianças ficavam brincando por ali. Quando a gente pensou, a gente nunca pensou em deslocar a mina, mas que a mina ficasse como lugar de lazer das crianças”

Este relato nos permite apreender a centralidade das ações da ACMA na favela, bem como a referência do projeto de urbanização, pois a garantia do espaço de uso possui a referência dos usos que a Associação faz daquele lugar. A ótica do empreendimento referendava as ações dos serviços postos ali, tanto que foi dado grande destaque a melhoria das vias de circulação. As melhorias também chegaram a 
população, pois o lugar de morada é também de realização dos serviços da ACMA, o que trataremos adiante.

O projeto de “urbanização da favela” refletirá, portanto, a relevância do conjunto de sujeitos que produziram este lugar. O espaço de uso conquistado, como a quadra de esportes e o parque das crianças, estão atrelados as concepções da liderança da favela e da ACMA respectivamente.

Cabe ressaltar que o papel da ACMA na continuidade da efetivação desta política se intensificava na proporção que se desmobilizava os moradores devidos às constantes paralisações das verbas da Prefeitura. Na estrutura da ACMA se institui a comissão de urbanização e esta assume, juntamente com a Assessoria Técnica, a responsabilidade pelo andamento das obras. Os trabalhos vão desde a prestação de contas até as idas e vindas em reuniões com a equipe da COHAB-SP. Conforme a arquiteta responsável houve uma descaracterização do mutirão,

“Descaracterizou completamente o mutirão. Não existe mutirão. Tem uma pequena equipe que faz"

O único morador da favela que participava ativamente era a liderança, que assumiu o cargo de mestre de obras. Este, por sua vez, contratava alguns outros moradores para fazer parte da equipe da construção.

No processo de urbanização, associado ao movimento interno da ampliação da Associação, há um distanciamento em relação à população, que em um primeiro momento pode permitir uma agilidade no processo em curso e consolidação do projeto da ACMA. Contudo, este distanciamento encaminha a população a exigir o cumprimento por parte da ACMA de suas demandas através de mecanismos assistencialistas o que acarreta a tensão entre estes dois sujeitos. Pois a Associação não possui a estrutura para suprir todas as solicitações.

Atualmente, na estrutura da ACMA há a comissão de urbanização que continua a gerenciar o projeto, pois ainda não foi finalizado. Mas, sua atuação se amplia com o processo de regularização fundiária. Ou seja, ela ratifica seu papel de mediação entre moradores e o poder público. Nos procedimentos de compra e venda realizada na favela após a regularização fundiária a ACMA se torna a mediação entre os contratos de compra e venda, ficando responsável por documentar a transição entre o comprador e vendedor.

Ao verificar a atuação da ACMA nesta política pública pudemos atentar para 0 fato de que a produção do lugar esteve predominantemente sob a tutela desta instituição. 
O projeto, o gerenciamento e a execução da obra estiveram sob seus marcos e a participação da população estava referendada no âmbito da execução, mesmo porque o papel da liderança ofuscava uma atuação direta deste sujeito.

Um dos elementos que apontamos como um conteúdo da degradação da vida é a impossibilidade de participação direta e autônoma da população do lugar nas instâncias de decisão. As relações de poder sob a direção da ACMA contidas no lugar impediram a elaboração de um projeto calcado nos desejos dos moradores e isto pôde acarretar a fissura necessária para a inserção de novos sujeitos na favela, que questionarão estas relações de poder.

\section{As Conquistas na Produção do Lugar}

A política de "urbanização de favela” não pode ser vista somente como um projeto que propiciou o alargamento da territorialização da ACMA. Ela representou conquistas significativas à população do ponto de vista dos espaços de uso conquistados e, mesmo por garantir o acesso à terra urbana em uma região que tende a se valorizar. Dessa maneira, a "urbanização" aparece enquanto possibilidade de resistência à degradação material da vida no lugar, tornando-a bem diferente das demais favelas da metrópole paulistana.

Um episódio significativo de resistência à terra urbana no momento de introdução desta política se refere as negociações realizadas nas reuniões de elaboração do projeto, no qual se conseguiu a redução da remoção do número de barracos. De 80 barracos a serem removidos (número previsto por um projeto anterior e que não havia participação da comunidade) houve a possibilidade de se reduzir para apenas seis. Isto somente foi possível pela participação dos moradores juntamente com a assessoria técnica e ACMA no tempo de elaboração do projeto. Atualmente, tais famílias aguardam alocação sobre um platô existente após a construção de alguns muros de contenção. 
INSERIR MAPA DE ESPAÇO DE USOS NA FAVELA 


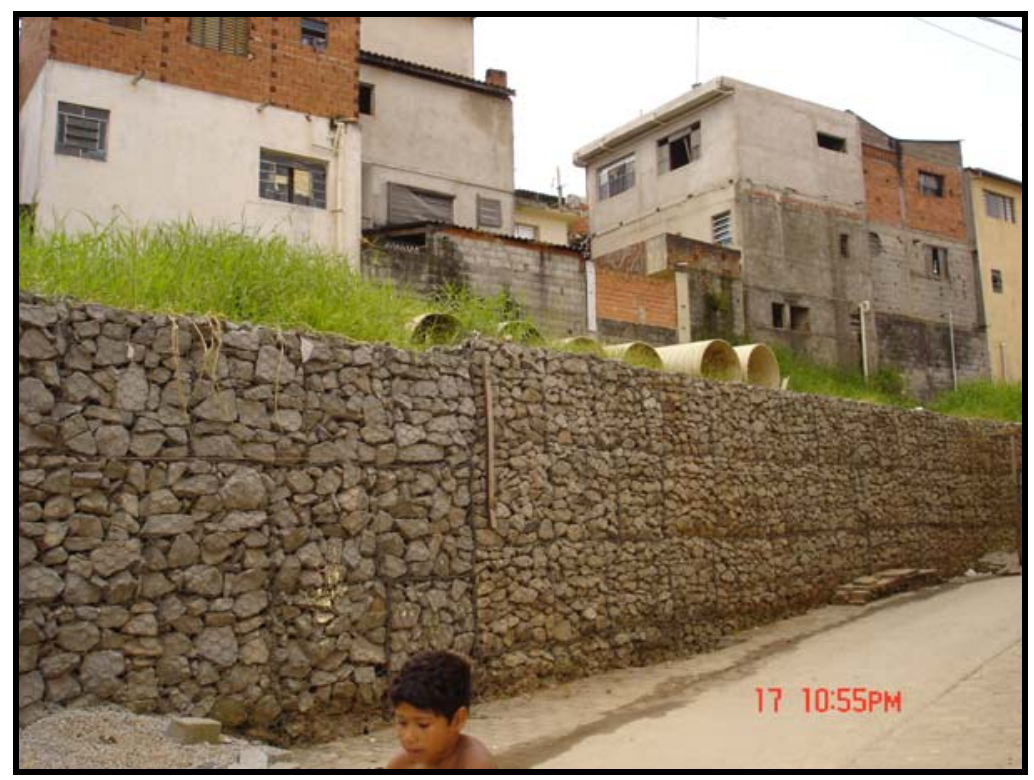

Foto 19: Platô onde serão erguidas as casas removidas com 0 processo de urbanização da favela. Autor: Ribeiro, F. V. Jan/2006

As conquistas infra-estruturais atingiram principalmente os traçados das vielas, isto é, as vias de circulação promovendo o trânsito de seus moradores em toda sua extensão. Portanto, diferente das demais favelas da região, decorrente do processo de urbanização da favela, as vielas são relativamente largas, chegando a até 2,5 metros de largura, permitindo maior circulação de ar nas residências.

As vielas, como vias de acesso necessárias para todas as atividades do dia-adia dos moradores, aparecem constantemente nas entrevistas, onde sempre são caracterizadas como um problema (de mobilidade e acessibilidade) a ser resolvido.

Seu Tião expressa este problema a partir de sua experiência de ida para o trabalho:

"Pior eram as condições de você andar na favela. Quando tava chovendo eu tive que voltar duas ou três

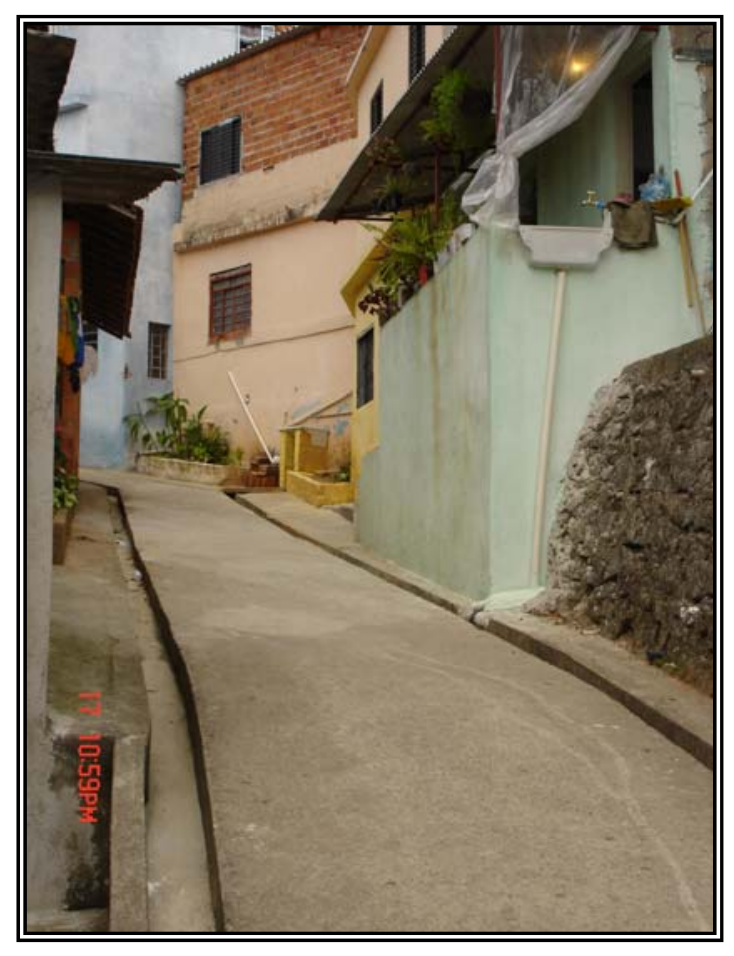

Foto 20 - Viela Setor Oeste Autor: Ribeiro, F. V.Jan/2006 
vezes para trocar de roupa porque eu caia e me lambuzava todo". ${ }^{40}$

Seu Paulo, se referindo as ações da Comissão de Moradores, localiza os trabalhos de intervenção contínua nas vielas, devido a precariedade:

“Melhorias de vielas. Porque antes, hoje tem toda essas escadas, mas ontem era tudo terra. Você imagina que de tempos em tempos tinha que estar retificando. Às vezes conseguia algum material junto a subprefeitura [na época era Administração Regional] e o pessoal ia trabalhando. E quando chovia tinha o deslizamento, caia barraco" ${ }^{41}$.

Hoje, elas são todas em concreto, com sistema de drenagem facilitando o escoamento superficial das águas para as caixas de vazão, que direcionam o fluxo para o córrego canalizado. O maior problema apontado é o acúmulo de lixo nestes caminhos, redundando na convocação, feita pela ACMA, para mutirões de limpeza do espaço de uso da favela.

Andando por elas percebemos a acentuada declividade em que se instalou os barracos da favela, explicando, em parte ${ }^{42}$, os motivos deste terreno não interessar, no momento de sua formação, ao circuito da troca.

Estas vielas dão acesso a porção central da favela. Por meio delas chegamos a um grande pátio onde há uma pequena piscina, a quadra poliesportiva com arquibancadas, o palco e o parque das crianças. Além de vermos o acesso que corta a favela norte - sul, pelo caminho produzido após a canalização do córrego, proporcionando maior mobilidade na extensão da favela e facilidades de acessibilidade ao terminal de ônibus e à estação do metrô.

Somente no governo Marta as obras ganham fôlego e radicalmente muda-se as feições da favela. Há a incorporação do projeto de canalização do córrego que corta a favela ampliando o espaço de uso. A quadra de esporte sai do papel, as crianças ganham uma piscina - devido a mina d’água existente no centro da favela - e um pequeno parque com brinquedos. Neste momento, amplia-se a territorialização da Associação Comunitária com os acessos aos equipamentos implantados (ambulatório, creches, biblioteca, padaria, etc).

Este espaço de uso produzido representa as relações de poder tecidas no âmbito do lugar, devido ao fato de grande parte destes espaços estarem permeados por normas

\footnotetext{
${ }^{40}$ Depoimento concedido em setembro de 2005.

${ }^{41}$ Depoimento dado em fevereiro de 2006.

${ }^{42}$ Este terreno também não interessa ao setor imobiliário, pois o trecho no qual a favela se assentou é de propriedade pública.
} 
advindas daqueles sujeitos que se territorializaram. Um exemplo a ser mencionado foi a quadra poliesportiva. Ela foi uma exigência da liderança da favela, que se colocava em posição contrária a ACMA, pois esta última queria a construção de uma praça (área verde). Ela é muito usada por seus moradores seja para os jogos dos jovens seja para a realização de festas e atividades artísticas.

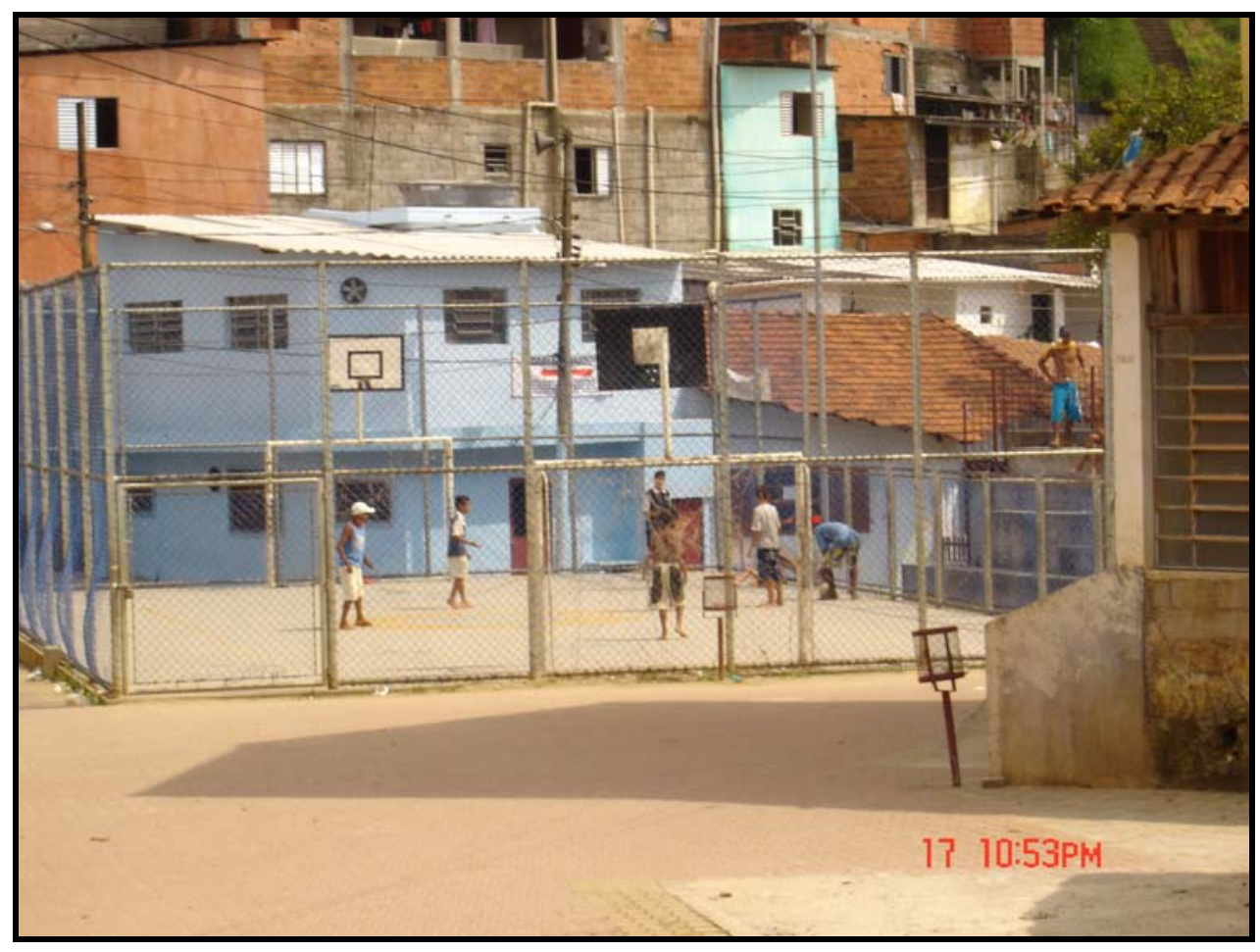

Foto 21: A quadra poliesportiva. Exigência da liderança da favela Autor: Ribeiro, F.V. Jan/2006

No centro da favela ainda estão a piscina e o parque recreativo. Ambos são usados pelas crianças e jovens da favela. Todavia, algumas regras são postas pela ACMA no uso do parque. O uso a todos está condicionado ao realizado pelas creches que estão ao lado, que possuem prioridade. Os brinquedos a serem colocados necessitam obedecer a concepção dada pela ação pedagógica da antroposofia, isto é, os brinquedos devem ser todos em madeira recusando aqueles em plástico ou outro material mais artificial. 


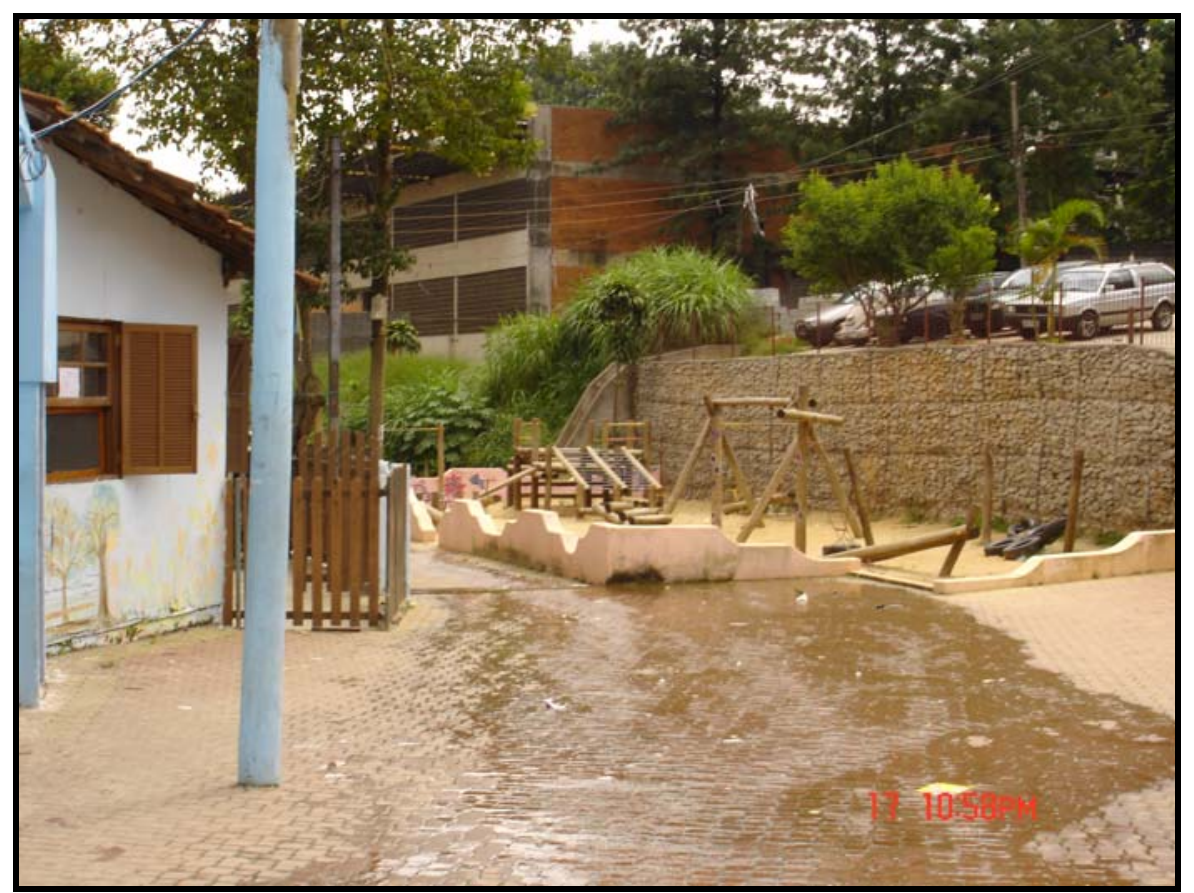

Foto 22: Parque Recreativo Autor: Ribeiro, F.V. Out/2006

Quanto a piscina, esta se torna diversão a todas as crianças. A única exigência da ACMA é não deixá-la transbordar, pois acarreta problemas ao trânsito das pessoas que vão aos prédios da Associação.

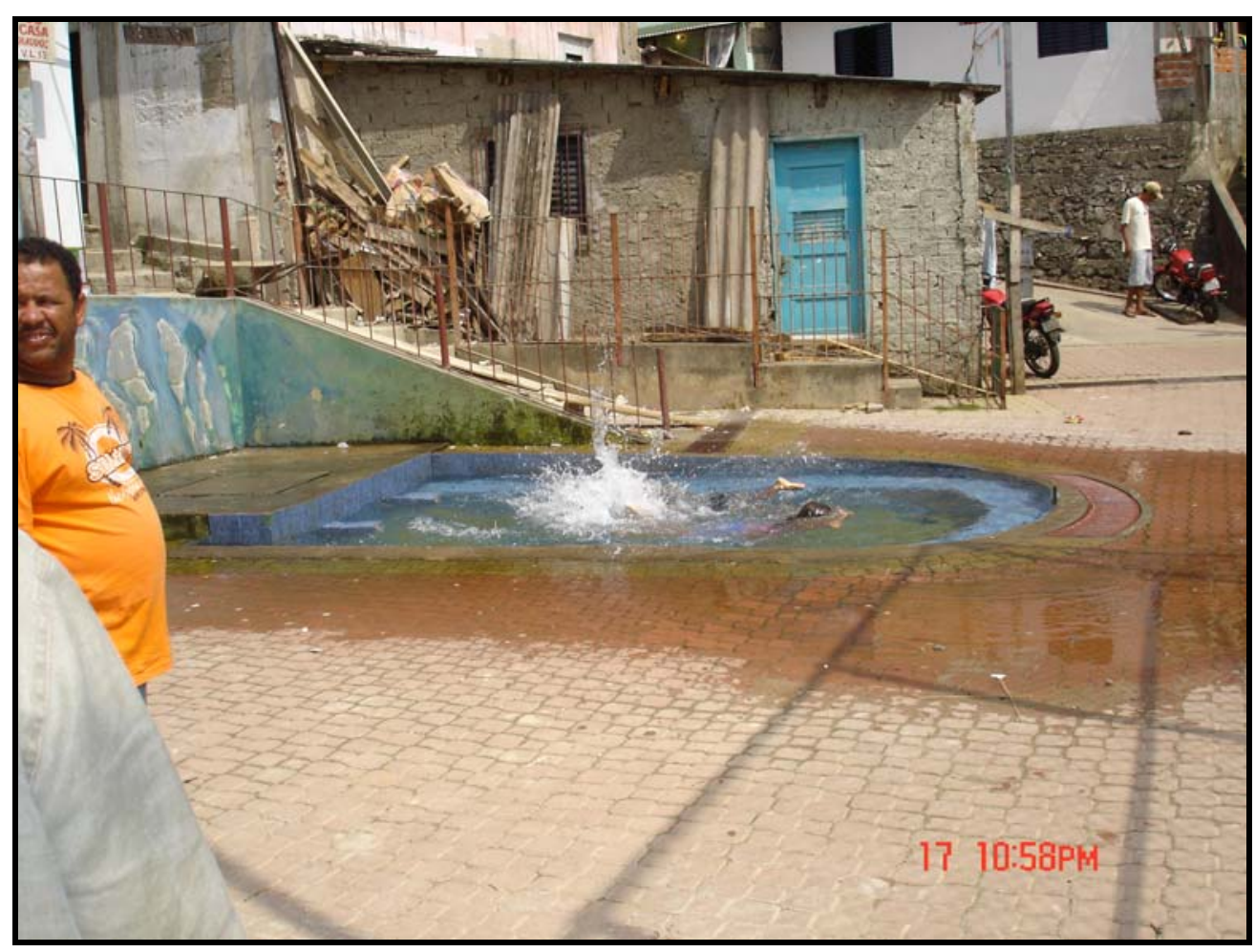

Foto 23: A piscina construída no intuito de preservar a mina que perpassa toda a história da Favela. Autor: Ribeiro, F.V. Jan/2006 
A etapa da "urbanização"que se conseguiu fazer, até o corte completo de verbas, foi a construção dos muros de arrimo eliminando os riscos da área e, permitindo a construção da Casa Amarela, que hoje é um espaço onde se encontra a biblioteca e o salão de reuniões dos moradores.

\section{O Aumento dos Preços das Casas na Favela}

Não podemos deixar de mencionar que além das conquistas introduzidas pelo processo de urbanização em relação à infra-estrutura, esta política pública aumentou os preços dos imóveis existentes. Não cabe aqui debater os mecanismos de sua valorização, mas sim pontuar a desigualdade empreendida internamente na favela, que propiciará formas de separação entre os moradores, destacando a incorporação de lógicas existentes nos demais loteamentos existentes na metrópole. Estas separações internas concebemos como um momento da degradação da vida, pois empobrece as relações de vizinhança. O sentido da segregação sócio-espacial está nesta ruptura em um dos planos da vida cotidiana, o âmbito do morar.

A casa é considerada como aquilo que mais nos aproxima do plano do privado. A casa é um dos elementos que revelam duplamente, na morfologia, a exploração do trabalhador, que não possui um salário que lhe permita a mínima condição de moradia, como também, a sua impossibilidade de uso pelas determinações da propriedade privada do solo, vista como a face mais contundente da fragmentação do espaço, já que esta produção se realiza na intencionalidade da sua inserção no processo produtivo. São elas que revelam os sinais da segregação sócio-espacial, que se funda na relação entre o valor-de-uso e valor-de-troca contido na mercadoria espaço.

Carlos afirma que:

“No conjunto da metrópole, a habitação revela com força a fragmentação do espaço, raiz da segregação que marca a reprodução do espaço em São Paulo; o entrelaçamento entre morfologia espacial e social aponta a desigualdade do processo fonte das contradições vividas"43

Por isso, o detalhe da produção das casas na favela revela também a sua reprodução, na medida que a favela vai se tornando um lugar de referência de moradia,

\footnotetext{
${ }^{43}$ Carlos, A. F., Algumas questões sobre a habitação na metrópole de São Paulo, In: O Espaço Urbano: Novos escritos sobre a cidade, Contexto, São Paulo, 2004.
} 
com a valorização de suas unidades, pelas políticas públicas concretizadas, aprofundando a fragmentação.

No primeiro momento, nos deparamos com a feição irregular das casas, característica dos assentamentos que ocuparam as vertentes íngremes do fundo de vale, com casas sobrepostas uma em cima da outra. Com predomínio da tonalidade marrom, cor dos blocos baianos usados na construção dos pisos superiores das casas. Mas, que estão "livres” dos riscos de escorregamento, porque um conjunto de muros de arrimo dá a sustentação necessária as vertentes nas quais as casas/sobrados estão assentadas.

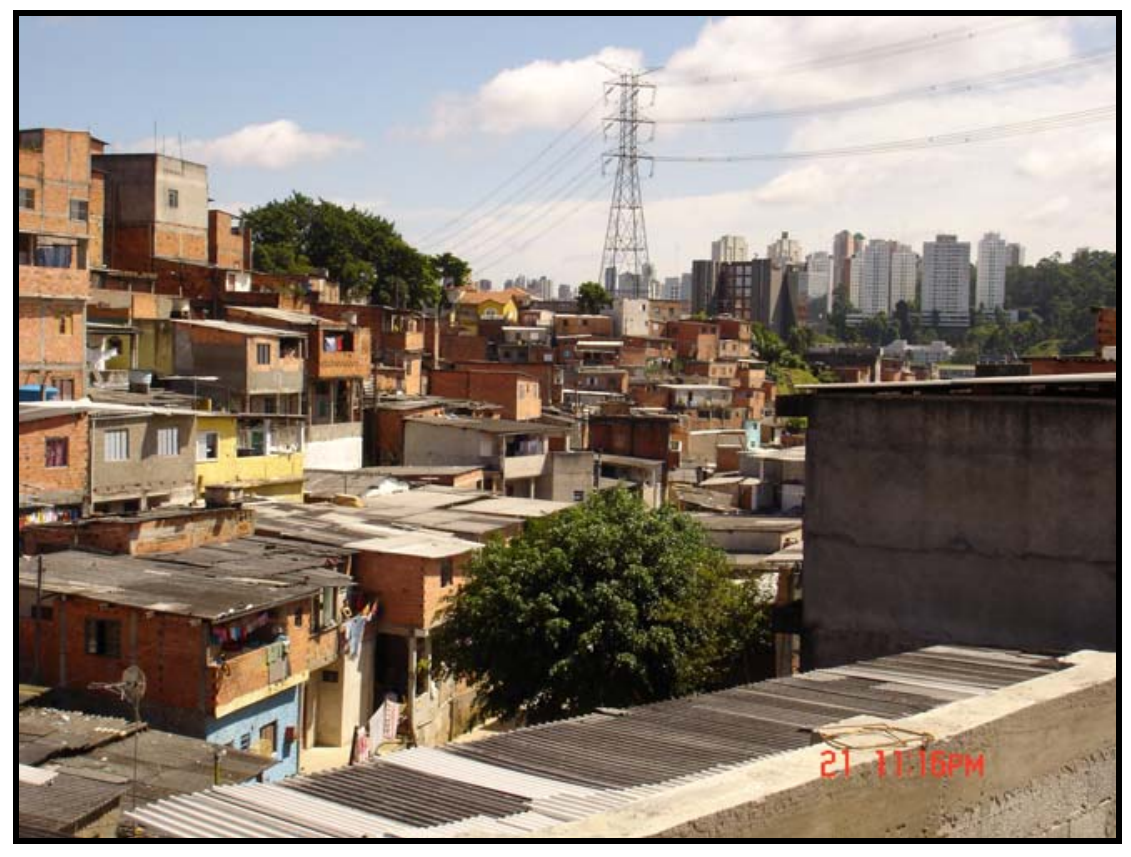

Foto 24:Casas na Favela Monte Azul

Autor: Ribeiro, F.V. Mar/2006

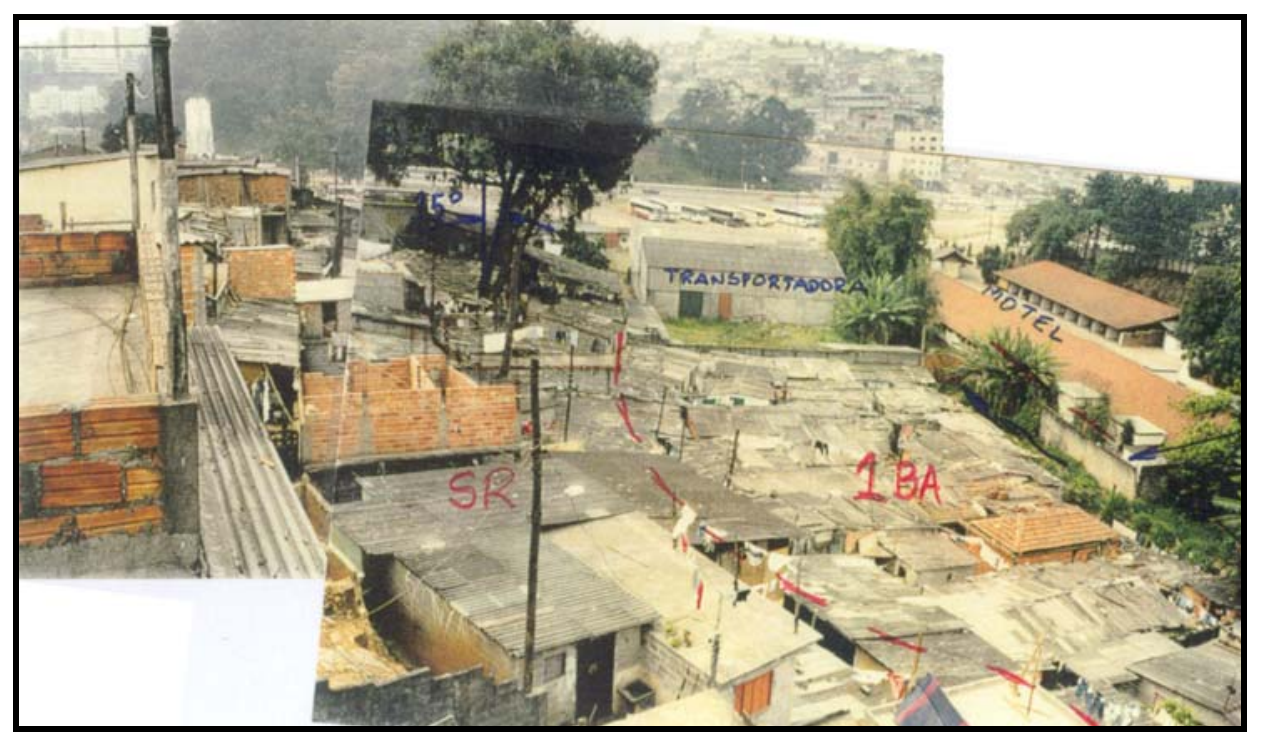

Foto 25:Casas da Favela Monte Azul. Grande parte ainda estava em madeira. Autor: Relatório Bureau. 1992 
Hoje, raras são aquelas que possuem somente um pavimento, o processo de verticalização está presente em toda a favela, denotando um adensamento de sua ocupação com o crescimento das famílias, que vão “batendo laje” para comportar todos.

“Teve uma verticalização, porque as famílias crescem. Então, a pessoa batelaje, como se diz, e constrói em cima. Então, o filho ou a filha é mais um que monta família...."44

No estudo de Merege, consta que segundo dados do Censo do IBGE de 1991 havia um total de 1.676 pessoas residindo em 383 domicílios. No convênio assinado em 1992 para a urbanização da favela, considerou-se o número de 423 famílias. Estima-se, atualmente, que a favela conte com uma população de 3.000 pessoas e cerca de 500 famílias (estimativa da ACMA) no ano de 2006.

Há ainda a presença de barracos em madeira na favela (seis), uma parte que ainda espera a finalização do "projeto de urbanização”, pois serão removidas para um platô existente ao lado do prédio do ambulatório (vide foto ??), e as demais (duas) são famílias que não conseguiram construir algo melhor por falta de condições financeiras.

A dinâmica da valorização de 2002 até hoje é evidente nos depoimentos, apresentando, por um lado, o impulso dado pelas obras de infra-estrutura, e por outro, a procura de pessoas por algum imóvel à venda na favela, que hoje é considerada bem localizada. Os atributos que a transformou em um lugar bem localizado são as possibilidades dadas pelo entorno. O volume de empregos, pela presença da área residencial de alto padrão, ou as condições favoráveis de acessibilidade e mobilidade as regiões onde se concentram trabalho, bem como as condições de infra-estrutura como hipermercados, e mesmo, os serviços prestados na área de saúde e educação pela ACMA nos mostram os motivos da permanência da população e da procurar de outros para residirem na favela.

O interessante a ser constatado é que a “urbanização da favela” proporcionou um aumento gigantesco do preço das casas/barracos existentes na favela. Mas, este fato não significou a expulsão de moradores, e sim, expandiu o processo de verticalização havendo a construção de mais patamares para que pudessem ser vendidos ou alugados.

Em relação ao valor "em si" das casas, este varia conforme a localização, o número de cômodos, se está próximo a rua com casas particulares, se possui ou não garagem, ou se a construção é estável ou não. Há uma variação de preços de R\$ 8 mil

\footnotetext{
${ }^{44}$ Depoimento Seu Paulo.
} 
até R \$ 50 mil. No depoimento do mestre de obras (liderança da favela) da "urbanização de favelas", que também possui uma pequena empreiteira, portanto, um dos conhecedores sobre os preços praticados na favela, nos fornece as seguintes informações:

"a mais barata que tem aqui hoje, mais barato ta em torno de $R \$ 8$ mil (...) Essa área aqui [se referindo a área da quadra], é uma área que todo mundo quer ..., tipo aquela casa azul, é em torno de $R \$ 35$ mil. A do Adão aqui, do sobradinho, é em torno de uns trinta também. Então, varia. Então, o que acontece, sempre ta localizado. Então, tem duas ou três casas que são um valor, tem outra duas casas mais bonitas que tem outro valor. Na beira da rua lá em cima a faixa é de quarenta (...) A casa do Bóia está avaliada hoje por cinqüenta mil, ou quarenta e oito mil, ou quarenta e cinco mil. (...) Com a urbanização ai vem essa questão, com a organização tinha casas que tavam na beira do córrego. Que estavam ali, caindo por cima do córrego. Com a canalização e a pavimentação ali, essas casas valorizaram."

"Tinha casas que valiam três mil ou quatro mil [referindo-se a aquelas localizadas na beira do córrego] e agora valem dez, quinze ou vinte". Justifica este aumento da seguinte maneira:

"Porque ela ficou de frente pra viela. (...) Aquele barraco que valia a dois anos atrás, em 2003, a três anos, que valia três mil, hoje vale vinte, hoje vale doze, hoje vale treze, hoje vale dezesseis e valia só três."

Situa também a grande procura de pessoas atraída pelas condições favoráveis

"E tem uma quantidade muito grande de pessoas que vem procurar ainda querendo saber se tem lugar na favela, se tem espaço ou querendo comprar".

A inserção desta política pública - urbanização da favela - significou um impacto profundo na vida daqueles que moram na favela. A melhoria na infra-estrutura, com a construção de ruas e espaços de uso representou um aumento do preço das casas. Mas, segundo os depoimentos, isso não representou a expulsão de famílias.

A saída dos moradores da favela nestes últimos anos se deve aos fatos atrelados ao próprio projeto de urbanização, que desalojou seis famílias. Somando a isso, há aquelas famílias que retornaram as cidades de origem nos estados de Minas Gerais ou 
Bahia, porque o chefe da família se aposentou. Entretanto, muitos que vão embora e deixam as casas para os filhos e netos que chegam, já que estes estão inseridos, por meio do trabalho ou do estudo, à metrópole.

Após todas estas conquistas perguntamos a alguns moradores sobre as relações com os vizinhos. Isto nos revelou as formas de separação na favela:

“A relação não tem problema. É harmônica, normal. Mas, a coletividade que não tem, entendeu? A coisa coletiva de comunidade é isso que não tem. Inclusive tem lugares, nós temos aqui dentro pequenos condomínios, entendeu? Se tem uma viela que não tem saída, as pessoas conversaram ali,e então, os vizinhos puseram o portão.”

“Cada um tem sua chave do portão. Por exemplo, quero falar com o Claudinho, você vai lá aperta o número dele, se tiver em casa bem, se não tiver...”

"As pessoas acham que isso se preserva mais"

Isto revela, alguns dos valores que rompem com os laços de solidariedade com os vizinhos, e ratifica a separação na vida privada dos moradores. No próprio depoimento, o “cercamento" de algumas vielas é visto como uma das formas de empobrecimento das relações sociais.

É este nível do privado - da casa - que alcança as práticas sócio-espaciais atravessadas pela lógica de afirmação da propriedade privada, demarcando o domínio sobre o espaço, e estabelecendo, mesmo num ínfimo trecho de sua casa - o quintal - as suas normas de convivência.

Em outra perspectiva, cabe comentar que as intervenções na favela por projetos não se realizaram apenas na sua infra-estrutura, as casas também foram objeto de ações.

Numa das ações da nova comissão de moradores - comissão jovem - trouxe um projeto que havia sido empreendido na favela de Heliópolis. A proposta era de revestimento das fachadas das casas com parceria da empresa de tintas Suvinil, no qual haveria a doação dos materiais por parte da empresa, e os beneficiados entrariam com a mão-de-obra.

Este projeto foi possível porque uma das moradoras da favela havia trabalhado como empregada doméstica na casa de uma senhora, que sensibilizada com as atividades da ACMA na favela, resolveu ajudar fazendo o contato com a empresa. Era preciso que um grupo de moradores se organizasse, o que ocorreu a partir de reuniões de alguns jovens. Mas, os problemas de comunicação, a escassez dos recursos (não era 
para todos o projeto), as pressões dos demais moradores e a inexperiência do grupo desmobilizou o projeto e só atingiu parte das 20 casas previstas, tornando mais evidente a diferença entre as casas na favela.

A precarização das habitações ainda é visível, mas presenciamos um constante trabalho de ampliação das casas dos moradores, de melhorias dos cômodos e, de certa maneira, um embelezamento da favela.

A casa, talvez, no movimento de empobrecimento da vida e das relações, represente o único espaço que possa ser apropriado conforme os valores daqueles que a habitam. O trabalho empregado na produção da casa representa, simultaneamente, a exploração do trabalhador, pois suas horas de descanso são gastas na produção da casa, mas representa também, seus esforços em ter uma casa para a reprodução da vida. Nesta última condição, a casa não é produzida visando o mercado, e sim a necessidade do morar, a finalidade é o valor-de-uso. A casa se torna mercadoria na medida que, pelas necessidades do capital, ao mobilizar a mão-de-obra ou o espaço, configura um ato de troca, e exige o sentido do valor-de-troca para tornar medida de valor intercambiável.

A degradação da vida neste plano do privado reside no fato de torná-lo o único momento de apropriação do espaço, no qual não está, em tese, subordinado ao espaçotempo dos sujeitos que se territorializam no lugar. Para garantir esta apropriação e não perdê-la, no limite estas ações vão na direção da perda das relações com os vizinhos na medida que se encerram em suas residências.

\section{A Disputa pelo Espaço de Uso: Fragmentação do Espaço?}

O conjunto de conquistas apresentado contem o conflito próprio de como o projeto se engendrou. Se nestes últimos itens destacamos as melhorias infra-estruturais não nos esquecemos que nascem também de tensões entre os sujeitos implicados nestas ações. A urbanização da favela se realiza para além das melhorias aos moradores, ela é vista como possibilidade de adequar o lugar aos acessos as atividades proporcionadas pela ACMA, e portanto, realiza o projeto antroposófico com a territorialização desta organização não governamental no terreno da favela. Todavia, este espaço se torna também o lugar privilegiado das transgressões daqueles que estão insatisfeitos com a presença da Associação.

Desse modo, a fissura para o embate de sujeitos que desejam se territorializar neste lugar, pois seus conteúdos proporcionaram a produção de uma centralidade na 
periferia, são dadas, e neste ponto encontramos o cerne da contradição apropriação e dominação do espaço.

Recentemente, este espaço de uso é objeto de conflito entre os vários sujeitos, principalmente entre os jovens e os mais velhos. Seu Paulo, ao falar dos usos deste espaço, nos coloca diante de um dos conflitos:

“Ai eu posso dizer que, principalmente essa parte aqui, a quadra essas coisas aqui, usam mal. Não usa bem. Infelizmente os jovens não conseguem cuidar, entende? Porque infelizmente tem aquela coisa, aquele conceito de que é público não é de ninguém. Então poderia ser muito mais bem cuidado. Mas justamente uma falta de uma comissão, que cuidasse ou ajudasse a cuidar, mas disso, na minha opinião, é o que nós falamos sempre. Infelizmente, o Nengo [mestre de obras que foi morto na semana do ataque do PCC à São Paulo] fica triste, porque ele vê as coisas que foram feitas, não é cuidada, quebram as coisas. Por exemplo, tem uma cerca..,. os jovens estão na arquibancada da quadra, quer vir pra cá, ao invés de dar a volta, pulam, e com isso desestabilizam a cerca, sabe? Então são coisas assim, sujeira, não cuidam direito. Chegam de noite e juntam lá, jogam copo, lixo, largam tudo lá. Isso infelizmente...” (grifos meus)

Para parte dos jovens que usam este espaço não o concebe enquanto um espaço coletivo, de uso público, portanto, da necessidade de cuidá-lo. Muitas vezes, estes jovens degradam este mesmo espaço de uso, como nos elementos apontados pelo trecho da entrevista. Daí decorre os conflitos com os mais velhos, que participaram da conquista deste espaço, e que hoje tenta mantê-lo em boas condições.

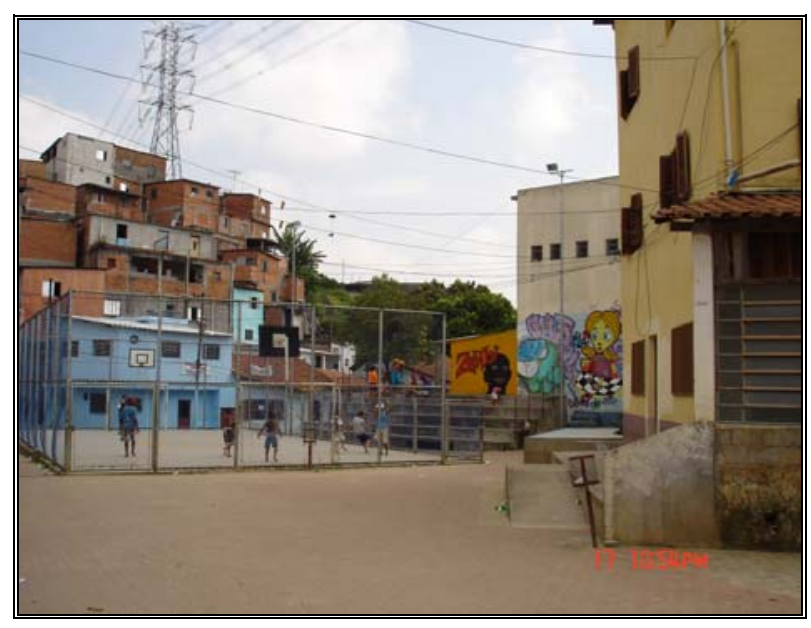

Foto 26 - A quadra poliesportiva. Centro da Favela. Autor: Ribeiro, F. V. Jan/2006 
Em relação a quadra de esportes, como já foi observado, serve às festas que a população realiza, destacadamente as festas juninas com quermesses organizadas pelos moradores tornando-se uma alternativa de ganho àqueles moradores que estão desempregados, pois há a venda de comidas e bebidas em cada barraca montada.

Porém, no ano de 2005, a festa junina, realizada durante todo o mês de junho na quadra, atraiu um enorme fluxo de pessoas. Conseguiu movimentar, através das barracas, uma quantidade razoável de dinheiro, e trouxe para si os negócios articulados ao tráfico de drogas, que estavam ainda em gestação, pois muitos jovens que se encontravam desempregados começaram a comercializá-las no perímetro externo à favela.

Na maioria das entrevistas realizadas este problema foi apontado seja pelos moradores seja pelos membros da ACMA. A sensação de segurança dada pelas atividades da Associação e garantida pela liderança da favela são estremecidas após a realização da festa junina neste espaço de uso:

“Aqui assim, aqui é muito seguro. Nesse último ano, em 2005, nós nunca tivemos problema aqui dentro. Nós tivemos muitos problemas no passado, nos anos $80^{45}$ era bem complicado aqui, depois mudou realmente e ficou muito tranqüilo. Nesse último ano de 2005, principalmente a partir do segundo semestre, ai nós começamos a nos preocupar, e esses jovens, justamente que tem essas complicações, começaram a se envolver com drogas aqui dentro, entendeu? Ai realmente começou a ficar preocupante. Eles ligados com outro de fora.(...)Isso aconteceu no segundo semestre pra cá, a partir da festa junina.(...) A partir da quermesse, a partir de junho. Foi exatamente em junho que começou."

Esta circunstância merece ser analisada a luz do significado que ganha o espaço no processo de urbanização, por meio da contradição apropriação-dominação do espaço. Pois ele revelou como uma favela, que se transformou numa centralidade na periferia, se torna também um espaço produtivo, no sentido que contêm particularidades positivas a realização do negócio do tráfico de drogas. Este fato também nos abre portas para

\footnotetext{
${ }^{45}$ Segundo conversas com moradores, na década de 80 havia as pessoas ligadas ao tráfico de armas, que foram expulsos pelos denominados "pé de pato". Esta figura merece destaque nas favelas e bairros da região periférica de São Paulo, pois representavam, e em algumas localidades ainda representam, os indivíduos que a partir do poder conquistado pela sua ação ilegal, ordena as relações dentro das favelas e bairros. Muitos moradores simpatizam com estas figuras, porque elas introduziram um código de conduta, que de certo modo "protege" os moradores de assaltos, estupros, e outros tipos de violência. Atualmente, esta figura está saindo de cena e muitas normas estão sendo quebradas pelos novos personagens ligados as recentes organizações criminosas.
} 
pensar as fragilidades de mobilização e organização da população frente a territorialização destes sujeitos, já que suas vidas estão permeadas por normas, que os levam a esperar as ações da ACMA, como instituição diretamente envolvida na disputa pela territorialização.

Estas insatisfações podem ser vistas por uma das falas dos moradores se referindo aos jovens da favela:

“A Monte Azul [ACMA] sempre tratou os meninos com o pé atrás aqui. Eles nunca confiaram nos meninos aqui. Por exemplo, vaga de emprego eles nunca deram, sempre dão pra um e outro, mas tem muita gente que trabalha aqui na Monte Azul que é de fora. Não é daqui. Essa é uma das maiores reclamações que os moradores tinham e sempre tiveram. A Monte Azul não dá oportunidade pra gente. Dá espaço pra gente de fora e não pra gente daqui."

Foi mencionado também um episódio em que parte dos jovens se dirigiu à ACMA para pedir apoio, e obtiveram como resposta a seguinte justificativa:

“Disseram que tinham uma linha de atuação, e a linha é essa. Não pode abrir muito. Não dá pra fazer tudo que vocês querem. O que dá pra fazer a gente faz, o que não dá a gente não faz”.

Outro episódio recente de uso da quadra de esporte torna mais evidente a tensão dos jovens e a ACMA. Houve no início do ano de 2007 uma festa de funk onde reuniu também um número considerável de pessoas. A estrutura se resumiu em um equipamento de som muito potente e bandas da região. O apoio para a contratação de todo o aparato necessário a festa não foi dado pela ACMA e a juventude que organizou a atividade não possuía o dinheiro. Resta-nos a incógnita de quem patrocinou a festa.

No bojo destes usos dos espaços conquistados nos é apontado uma possibilidade de dissolução deste próprio espaço de uso conforme se realizam estes tipos de transgressões à territorialização da ACMA.

Nesta parte procurei mostra a ação da ACMA. Ela se legitimou pelas ações assistencialistas que supriam as necessidades da população. Para tanto penetra na favela erguendo seus prédios e se territorializa, isto é, constrói relações de poder normatizando o espaço. Neste processo há um embate da dominação que a ACMA tende ter sobre o espaço com os usos e formas de apropriação que a população faz de seu lugar de morada. Com a urbanização da favela tenta-se garantir as vias de 
circulação que dão acesso aos serviços implicando num aprofundamento da territorialização deste sujeito. Todavia, isto a conduz a um aprofundamento de suas normas enquadrando, principalmente, os jovens a seu projeto. Na medida que tenta enquadrá-los estes saem de suas amarras produzindo seus próprios projetos, fazendo uso deste espaço de outra maneira. Isto abre "brechas" para os outros sujeitos se territorializarem, pois estes ganham legitimidade a partir do momento que suprem as necessidades destes jovens.

Atualmente a ACMA afirma a presença deste novo sujeito o caracterizando como o maior problema do período. Isto denota o embate de territorialização.

Nesta trama complexa, os moradores se utilizam das fissuras para transgredirem e se apropriarem do espaço conforme os desejos que possuem. Mas, parte deste mesmos moradores não conseguem enfrentar este problema solicitando a intervenção da ACMA.

Procuramos nesta parte mostrar a degradação da vida urbana pelo viés da redução das possibilidades de apropriação do espaço urbano nas facetas da precarização da participação e organização da população e as transgressões que reproduzem relações de assistencialismo.

\section{Os Limites das Ações Assistencialistas}

Martins, nos permite pensar amplamente a relação conflituosa entre a ACMA e seus moradores, ao abordar o tema da "exclusão social" 46 . No texto ele expõe as implicações da interpretação calcada na noção de “exclusão social”, afirmando a característica conservadora que há por trás dele, já que este não toca as contradições, apenas lamenta condição de excluído. Nesta lógica, o excluído,

"é capturado como consumidor marginal, porque suas necessidades estão limitadas ao que pode ser satisfeitos pelos resíduos do sistema. Não são necessidades que o lancem para além do atual. Suas necessidades são necessidades que afirmam as liturgias da sociedade de consumo, seu valores e ideais.”36 O “excluído” afirmará o papel central da modernidade “Cada um é o que parece ser e não o que é de 'fato'."

\footnotetext{
${ }^{46}$ Martins, J. S., A sociedade vista do abismo: Reflexão critica sobre o tema da "exclusão social”, São Paulo, 2002.
} 
A Associação Comunitária Monte Azul, com a prática assistencialista, ratifica esta “inclusão", ao apenas se limitar as conquistas tidas na favela, aos serviços e proporcionar aos seus moradores, pelo menos em discurso, a inserção em empregos pela capacitação feita por meio das oficinas, que muitas vezes, pode não garantir este posto de trabalho, como o que ocorre atualmente. O fundamento da condição na qual estão imersos não foi objeto das práticas da ACMA.

Seguindo a linha de raciocínio do autor, a necessidade construída de continuar a reprodução da lógica do 'parecer ter" tem implicações perversas no sentido de proporcionar formas degradadas de participação, isto é

“Diferenciam-se na medida em que, ao afirmarem os fins dessa sociedade, negam os meios que para eles se tornaram inacessíveis. No limite, podem usar meios ilícitos para obter os recursos de que necessitam para integrarse: o tráfico, o roubo, a violência, os meios transgressivos de participação. A deterioração dos valores éticos que deveriam permear as relações sociais, e que daí resulta, já produz seus desastrosos efeitos na socialização anômica das novas gerações, na vivência cotidiana atravessada pela violência.

(...)Estamos em face de um processo de dupla característica. De um lado, em face de que, sociologicamente, situações como a de exclusão induzem à criatividade social, à inventividade. Em situações assim, o poder da ordem se manifesta na busca de alternativas de integração social, de reconstituição do tecido social rompido. A própria vítima regenera rapidamente aquilo que falta para se situar interpretativamente na realidade que parece empurrá-la para fora, excluí-la.

Uma segunda característica do processo é que os que se incomodam não só com a exclusão, mas, sobretudo, com as vítimas dos processos sociais excludentes, têm dificuldade para compreender e aceitar essa criatividade. Em outras palavras, os que querem ajudar os 'excluídos' estão em aberto e político conflito com os que já se ajudam.”39/40.

Na medida que a ACMA não proporciona a reprodução de parte dos moradores, cumprindo a lógica do "parecer ter”, este próprios moradores se valerão de outras alternativas para continuar a suprir as necessidades da perpetuação da aparência. Isto porá um conflito entre moradores e ACMA, pois esta última perderá legitimidade por não se representar mais como o agente portador desta possibilidade, podendo 
encaminhar-se para o questionamento de sua territorialização e abrir o caminho para a inserção de sujeitos ligados à violência urbana - trafico de drogas - que representa hoje, a alternativa aos jovens de continuar a conquistar os elementos do "parecer ter".

A conquista por espaços de uso se concretiza, mas como a favela se insere como um lugar da metrópole e comporta as tendências da urbanização, o espaço de uso produzido a partir destes sujeitos se transforma em espaço de disputa. Isto é, a precarização da vida vista pela degradação do lugar de morada é superada pela possibilidade de uma política pública como a urbanização de favela. Mas, na medida que a ACMA se territorializa insere as suas normas, que impedem usos da população, para que deixem o espaço de uso ordenado as demandas dos serviços ali existentes, este próprio espaço se dissolve.

O que presenciamos são ações de manutenção organizadas pela Associação e não pelos seus moradores. A limpeza do espaço de uso é um exemplo no qual a convocação é realizada pela ACMA e a participação dos moradores é reduzida.

O que podemos perceber é que se conseguiu melhorias infra-estruturais de grande porte, mas centrada nos ditames e organização da ACMA, não de seus moradores, que atualmente aparece no caráter ambíguo da população a esta instituição, isto é, as falas que nos deparamos dos moradores em relação ao desempenho da Associação, é que reconhecem os serviços existentes na favela, a melhoria das condições materiais, mas que a ACMA realiza atividades que servem apenas a ela, e não correspondem as demandas daqueles que vivem nesta favela. Alguns dizem que se sentem usados por ela, pois são somente convocados em mutirões de limpeza.

Consideramos, portanto, que o processo de urbanização aparece como uma representação de que mesmo com as conquistas aqui destacadas, o processo no qual se efetivou não proporcionou um espaço a ser apropriado para as experiências de politização da população, mas empreendeu um fortalecimento das relações, desde o princípio estabelecidas, de assistencialismo. Estas relações seriam também a base das tensões atuais entre moradores e ACMA, pois os primeiros remetem a solução de suas demandas a Associação e o segundo, por limitações a suprem precariamente. 


\section{A Atividade Teatral na Associação Comunitária Monte Azul}

A pesquisa se propôs inicialmente a buscar as formas de resistência à degradação da vida urbana na periferia da metrópole paulistana a partir de práticas sócio-espaciais que não envolvessem a mediação da troca e produzissem espaços de sociabilidade. Nestes espaços, os sujeitos implicados poderiam construir uma identidade concreta por meio dos usos intrínsecos de tais atividades exercidas.

Logo de início, as primeiras leituras nos indicaram que as atividades atreladas ao campo das artes apareciam potentes para desenvolvermos a idéia do projeto. Dessa forma, procuramos os lugares da metrópole que exercessem tais atividades e chegamos à Associação Comunitária Monte Azul, que é referência na área cultural. Esse patamar de referência se construiu a partir de trabalhos junto aos moradores da favela, abrangendo a área de música, teatro e dança. As produções realizadas se introduziam nos circuitos dos festivais tanto nacionais como internacionais (vide anexo de reportagens).

Desse modo, foi se erigindo uma centralidade na periferia com um conteúdo lúdico, mostrando a possibilidade de se fazer arte na periferia sem passar pela mediação da troca. Apresentava-se, portanto, como um espaço de sociabilidade potente de debates sobre a vida cotidiana da população do entorno, principalmente aqueles que residiam na favela, transformando-se em uma oportunidade de construção de um espaço de experiências de politização.

Esta centralidade produzida nos instigou a compreendê-la porque aparecia enquanto um lugar que negava a tendência hegemônica da produção do espaço urbano, isto é, a da sobreposição do valor-de-troca sobre o valor-de-uso. Contudo, no decorrer da pesquisa enriquecemos esta hipótese na proporção que descobríamos a complexidade do próprio sujeito que oferecia tais atividades. Desta forma, optamos pelo estudo da atividade teatral, concebendo-a como a mediação para a produção de um espaço de sociabilidade que contém as possibilidades de apropriação do espaço à medida que se faz uso do próprio espaço da Associação, mas que se confronta com as normas do projeto antroposófico, que tenta normatizá-lo.

A atividade ganha importância também pelo fato de nos encaminhar para a compreensão das relações internas da Associação. Ou seja, evidencia que as pessoas inseridas nas coordenações não concebem de forma igual e homogênea as ações, 
havendo uma tensão, que tem seu fundamento na concepção do projeto antroposófico. A história do teatro nos revela estas transgressões tanto dos coordenadores dessa área como também dos participantes na medida que se defrontam com os espaços-tempos diferenciados. Nos oferece a luta interna à instituição contra a degradação da vida efetuada pela normatização imposta por esta mesma instituição.

O Centro Cultural Monte Azul representa, aos que trabalham com cultura, uma referência, por nela reunir em Mostras que ocorrem ao longo do ano, trabalhos de música, dança e teatro. Seu espaço é aberto a vários grupos amadores e profissionais, além de apresentar momentos de debate sobre as políticas públicas de cultura e unir jovens de partes distintas da metrópole, principalmente aqueles que residem na própria favela. Para aqueles que praticam o teatro significa uma oportunidade de fazer uma atividade sem ter a mediação da troca, como também, de experimentar uma nova relação espaço-tempo, mesmo que esteja permeada pelas noramtizações da instituição.

Para a presente pesquisa, as linhas gerais aqui apresentadas pretende mostrar a história e a prática desta mediação para a apropriação do espaço, restando ao último período uma análise detalhada do conflito que permeia esta prática sócio-espacial.

É preciso resgatar que o teatro feito na Associação Comunitária Monte Azul já possui uma história longa com a construção de várias experiências, na medida em que aprofundava os trabalhos realizados com os moradores da favela. O projeto proposto pela ACMA enfatizava a importância desta atividade para o desenvolvimento e crescimento do ser humano. Para o grupo de coordenadores deste núcleo teatral esta prática representava uma forma de reflexão dos moradores sobre sua realidade, ampliando a visão dada pelo projeto antroposófico. Este último apreende tal prática apenas no âmbito pedagógico e não enquanto oportunidade de questionamento sobre a condição na qual se encontravam aqueles que a faziam.

Em um primeiro momento, portanto, o teatro estava somente articulado a antroposofia, isto é, fazia-o abrindo um livro e dramatizando aquela história juntamente com os alunos. Posteriormente, une-se ao núcleo um grupo que propõe outra prática incorporando como central os debates sobre a realidade de nosso país. Esta nova prática conduziu à construção de peças que tocassem em aspectos relevantes para os moradores, mas também à organização da população para a realização do trabalho social proposto pela Associação.

Neste período, várias peças são produzidas coletivamente em um grupo de 10 pessoas, na maioria moradores da favela, e que participavam ativamente dos mutirões e 
ações na favela. Podemos elencar as experiências da peça “Ai que vida”, que conta a história de uma família de migrantes na cidade de São Paulo e os grandes desafios a serem enfrentados. Houve um trabalho intitulado "Causa Maior", que trata da problemática do menor no Brasil com suas conseqüências para nossa sociedade. Existiram outras montagens referindo-se as questões mais urgentes, como o tema da aids e dos 500 anos do Brasil. Muitas pessoas se inserem no processo, os moradores da favela, os voluntários da Associação e o diretor das peças. Este diretor - coordenador do núcleo teatral - trouxe a perspectiva do Teatro do Oprimido à cena. Por meio desta ótica o trabalho era realizado, isto é, se pautava pela necessidade da participação ativa de todos, inclusive do público.

Data daí a construção em alvenaria do Centro Cultural, que viria a comportar a estrutura de palco existente. O formato de semi-arena já representa uma concepção de interação entre platéia e palco, revelando uma arquitetura que tenta romper o isolamento do ator em relação ao espectador (concepção diferente das tradicionais caixas do teatro italiano e isabelitano). ${ }^{47}$ Este formato produzido atribuímos às concepções do grupo inicial de teatro, que na história da ACMA, apreendia esta atividade como momento possível de se pensar sobre a realidade vivida na favela. Esta forma do "fazer teatro" se chocou desde o início com o projeto da ACMA revelando que esta atividade, mesmo realizada dentro da Associação, transgredia as normas do projeto antropósofico.

Este grupo também propiciou a inserção das peças em Festivais e viagens por várias cidades, inclusive para o exterior. Dessa maneira, demonstravam o trabalho do grupo e levavam o nome da Associação. Assim, a atividade cultural produziu a visibilidade da ACMA e dos trabalhos realizados na favela à metrópole (não se restringindo ao universo da antroposofia ou do terceiro setor).

\section{Os Conflitos de Concepções do "Fazer" Teatro}

Estas ações na área do teatro adquiriram robustez e se transformaram em referência aos diversos grupos na metrópole. Ao mesmo tempo o uso deste equipamento

\footnotetext{
${ }^{47}$ Bertold Brecht em seu escritos traz a idéia de que rejeita a desigualdade social refletida pela sala italiana e condena o ilusionismo e a relação alucinatória que o palco fechado possibilita. Ele pede que o palco se torne uma área de jogo, um espaço concebido em função da representação do ator. O espectador tem constantemente consciência de estar assistindo uma representação, mantém a distancia dela, não se envolve, mas julga criticamente os fatos que lhe são apresentados. A arquitetura desta estrutura é fundamental para se conseguir a interação com o público. A estrutura em arena é uma das formas que proporciona esta interação com o público. No mesmo sentido esta estrutura é incorporada por aqueles que seguem a linha do teatro do oprimido.
} 
- raro na periferia - foi multiplicado. Se realizou festivais com grupos amadores e profissionais, se apresentou peças dos grupos de referência (Teatro Oficina), se ampliou o número de membros desta atividade. Neste ritmo não tardou os conflitos entre os coordenadores do núcleo teatral e os fundadores da Associação.

O relato de Cido assinala dois momentos. O primeiro é a tensão entre o projeto do grupo interno de teatro e a visão da antroposofia, que vê a arte não em seu âmbito político, mas a reduz a um instrumento exclusivamente pedagógico. E o segundo, revela a prática teatral como momento de reflexão dos problemas enfrentados na metrópole por aqueles que participam (ou participaram):

“O teatro foi um pouco difícil, pois quando se trata de teatro na Antroposofia tem uma preocupação maior, qual o método que se vai trabalhar com o teatro, teatro para criança de cinco anos, para quinze anos. Então isso tem uma certa separação, pois está ligado a esta coisa do crescimento e desenvolvimento (...) ai a gente se deparou com umas discussões quando o Amauri [primeiro diretor/coordenador da atividade teatral] veio, pois o Amauri tinha uma outra cabeça, ele queria fazer um trabalho do teatro de oprimido. Muitas vezes a Ute [fundadora da ACMA] achava que tinha que limitar certas coisas, então houve certos desentendimentos para se encaixar dentro do trabalho, mas foi meio complicado” (...) “Quando o Amauri começou a fazer o trabalho... Eu conheci o Amauri na Toca, uma entidade aqui perto. Ele dava aula de teatro lá. Ele tinha um grupo de teatro lá. E ai[tinha] a Glaia [membro da ACMA desde sua fundação] trabalhava comigo, e gente queria ampliar esse conhecimento, e [aumentava] a vontade de atuar, e ai começamos a formar o grupo, se encontrar aos sábados aqui, ler e discutir. A primeira peça encenada aqui foi “Ai que vida”, uma história de uma família de migrantes, pais, mães e filhos com seus problemas aqui em São Paulo, e essa peça viajou muito. Depois, a segunda foi “Causa Maior”, em que eu participei, e essa viajou para o Chile, Paraguai, Equador, falava sobre criança abandonada. (...) o nosso trabalho era um trabalho social, é o que dentro da arte a gente poderia contribuir. Então isso ia a tona. Então ia falar de um menino abandonado. Tinha a pesquisa e a gente ia no ônibus, ia nas igrejas, nas favelas e a problemática da criança que apanha da polícia, que 
apanha em casa, ai fizemos uma peça que ficou muito legal, e que fazia uma

discussão e um debate sobre." 48

O depoimento nos apontou que nos primórdios da atividade teatral se propunha refletir sobre as formas de apreender as vivências dos moradores da favela na periferia, num espaço de reunião, mediado por este uso, criando a oportunidade das experiências de politização da vida cotidiana. No entanto, este espaço se reduz, pois a perspectiva de politização dos moradores não condizia com as normas da ACMA (visão assistencialista). As tensões foram se avolumando e parte do grupo se retirou da Associação pelas impossibilidades de continuidade do trabalho.

De acordo com os relatos concedidos muitas eram as formas de cerceamento das atividades. Elas transitavam desde o contingenciamento de recursos até a censura aos grupos que se apresentavam. Um exemplo foi o episódio da apresentação do grupo do Teatro Oficina $^{49}$, na qual a membro fundadora da ACMA, Ute Craemer, determinou que peças elaboradas por eles não seriam apresentadas no centro cultural, pois tratavam de temas não adequados.

A saída deste grupo e daqueles que atuavam acarretou a limitação das possibilidades de uso do espaço aos ditames assistencialistas, obscurecendo as formas de reflexão sobre a realidade. Ainda assim, o núcleo se reestruturou, mas não nos moldes postos pelo grupo anterior, e sim, com práticas que gestaram um grupo que luta por realizar o teatro de uma maneira diversa da apregoada pela Associação reatualizando os conflitos existentes anteriormente.

\section{A Nova Fase do Núcleo Teatral}

Após o afastamento desta primeira equipe houve uma pausa nos trabalhos. O núcleo se reestrutura no ano 2000 e uma outra fase se apresenta ao grupo teatral da Monte Azul. Há a ampliação do número de participantes oriundos de outros bairros e em idades de 10 até os 26 anos. Formam-se três grupos, cada qual com uma proposta diferente. O primeiro que incorpora crianças e jovens iniciantes, um segundo, que possui um trabalho com jovens que já perfizeram uma história na Associação, e por fim, o terceiro grupo composto pelos jovens que conseguiram se profissionalizar na área. Dentre eles grande parte são moradores da favela.

\footnotetext{
${ }^{48}$ Depoimento de Aparecido Candido - Cido - em 10 de agosto de 2005.

${ }^{49}$ Grupo teatral de referência internacional coordenado por José Celso Martinez.
} 
Cada grupo possui uma dinâmica de trabalho. Tivemos a oportunidade de acompanhar nos anos de 2005 e 2006 parte das atividades do grupo 01, por nele reunir o maior número de jovens e que estavam iniciando seu percurso nesta atividade, e mais tarde a atuação do grupo 03, já que os seus membros coordenavam a área.

Começamos relatando as práticas que envolviam as ações para a construção da obra. Isto se faz importante, pois demonstra como a apropriação do espaço mediada pela arte exige um exercício de coletividade e de ações diretas que traz a possibilidade de produção da identidade no interior dos grupos. É este potencial que oferece a este uso do espaço a capacidade de transgressão, pois promove ações de questionamento.

Tratamos primeiro do grupo 01. O trabalho de campo conseguiu acompanhar o final do processo e início de outro completando o ciclo realizado no ano. No momento em que nos inseríamos era a época na qual estava se preparando para a estréia de uma peça chamada "Parlenda". Seu tema dizia respeito sobretudo as lendas brasileiras como momento de busca pelas raízes da cultura brasileira, a partir do folclore, das tradições, da história e das brincadeiras. O diretor do teatro nos relata o objetivo de um tema como este:

“Eu tenho muito essa questão do Brasil, não é que não goste do estrangeiro, eu sinto que o Brasil tem tanta coisa que a gente precisa trabalhar, mostrar a cara do Brasil para o povo."

Para elaborar esta idéia o grupo precisou realizar uma vasta pesquisa com os parentes e em recursos das bibliotecas. Cada um se responsabilizou por trazer uma lenda brasileira e construir um pequeno texto para que fosse incorporado á peça. Esta tarefa exigiu a coordenação do responsável na construção de relações de coletividade transformando a área do teatro no palco das discussões e embates na composição da peça. Os jovens simultaneamente experimentavam a "arte” de debater na dinâmica do ouvir e falar. Evidente que isto não ocorre sem desentendimentos e conflitos internos, no entanto, a necessidade de construção da peça de certa forma os faziam superar tais questões.

A divisão de tarefas reclamada na atividade também os levavam a compreender o sentido do trabalho cooperado, porque a cada ensaio ou apresentação se determinada tarefa não fosse executada comprometia o grupo por inteiro.

Tais reflexões eram tratadas nos momentos dedicados a avaliação que consistiam em um modo de avaliação do grupo e auto-avaliação. Neste momento, cada um expressava suas sensações em relação ao grupo, ao público e a sua atuação. Muitas 
vezes os participantes eram instigados a sugerir as soluções para os problemas elencados.

Deste grupo tivemos a oportunidade de realizar entrevistas que relataram recorrentemente as mudanças em suas vidas. As destacadas foram: a descoberta do gosto pela leitura que adquiriram no processo de pesquisa das peças, e a melhoria dos diálogos com a família, porque neste mesmo exercício da pesquisa, os temas resvalavam nas histórias de vida de seus pais ou avós.

Algumas frases tentam sintetizar estas mudanças percebidas:

"O teatro dá liberdade."

“Aprendi a gostar de ler”.

“Comecei a ler e prestar mais atenção nas coisas”.

“Me ajuda também na escola”.

“Faço amizade mais fácil”.

“Mudou até meu gosto musical"50

De experiências desta ordem que surgiram os demais grupos existentes na ACMA. Ressaltamos a experiência do grupo 03. Como dito, parte deste grupo que atualmente coordena as atividades do núcleo propondo debates, fóruns, mostras e peças com um teor que não condiz com as diretrizes da ACMA.

Este último grupo é muito tolhido em suas atividades por meio dos mesmos constrangimentos postos ao grupo original da ACMA (cortes financeiros e não auxílio na divulgação dos trabalhos), pois eles além de terem como proposta encenar peças de cunho político, como a de Plínio Marcos intitulada "Balada de um Palhaço”, também escolheram seguir profissionalmente tal área. Estes dois aspectos não corroboram com o projeto antroposófico criando profundas tensões entre a coordenação do núcleo teatral e a coordenação geral da ACMA.

Entretanto, ainda criam formas de debater as questões relativas as políticas culturais como o I Fórum de Teatro Monte Azul realizado em maio do ano de 2006 tratando os assuntos relativos ao papel do Sindicato dos Artistas (SATED), o papel cidadão do artista, as experiências de grupos reconhecidos como a Companhia do Feijão, o relato da vivência com grupos da região, além das apresentações de peças com um conteúdo que denunciavam as condições sociais da população (“A ralé ainda pulsa”, “O Santo Capão” e "Canibais da Alma”), sarau com as poesias dos artistas regionais, e enfim, a

\footnotetext{
${ }^{50}$ Entrevistas realizadas em outubro e novembro de 2005 com os integrantes do grupo 01, que na época estavam ensaiando a peça intitulada "Parlenda".
} 
apresentação da peça Parlenda na quadra poliesportiva da favela. Esta última atividade permitiu a interação com a comunidade da favela.

Mesmo com tais tensões, o trabalho realizado nos grupos permite uma prática não mediada pela relação de troca pautada na mercadoria, além de exercitar práticas de coletividade e cooperação, pois exige o trabalho de todos na construção da obra a ser apresentada.

São peças com temas que resgatam a história. Um exemplo também a ser descrito é a montagem da peça nomeada "Cora Coralina" destacando a poesia de uma escritora referência da literatura brasileira. Após este trabalho e continuando a proposta de resgatar os elementos brasileiros e apresentá-los pelos Festivais começa uma a pesquisa sobre o indígena, fazendo uma reflexão sobre sua realidade. Esta reflexão se faz trazendo para a cena debates contemporâneos, e também, o resgate da memória do povo.

Tais atividades, mesmo permeada pelas normas da Associação podem ser relativizada, diferentemente do processo de urbanização, pois o teatro e a arte, por suas características peculiares, exige a participação direta daqueles que o praticam, como também, o trabalho de cooperação entre seus participantes. Este diferencial pode nos apontar, principalmente, por não estar mediado pelo dinheiro, mas pelas normas que constantemente são transgredidas para conseguir realizá-las, um uso que permite a apropriação do espaço na metrópole paulistana. É dessa maneira, que esta atividade adquire relevância na pesquisa. As possibilidades de transgressão na periferia, mesmo das normas que são impostas por instituições que se territorializam no lugar são constantemente realizadas como meio de sobrevivência.

\section{A Arte das Transgressões}

O ato de reproduzir a vida sob a égide da reprodução do capital é a arte das transgressões, isto é, se confrontar a todo instante com as formas de degradação da vida urbana que invade todos os momentos da vida cotidiana.

A vida constantemente está sendo programada pelas determinações impostas pelo urbano e, desse modo, se acelera implodindo as relações de vizinhança, de cooperação, de coletividade e tantas outras que nos projeta a enriquecer a relação com o outro. O produto deste processo é o empobrecimento do humano. Todavia, ao nos debruçarmos sobre as próprias formas de dominação descobrimos, mesmo 
residualmente, as transgressões que nos encaminha as apropriações do espaço. Verificamos que o espaço-tempo da vida não foi plenamente cooptado pelas relações de troca, mas que em meio às formas de alienação, que insistem em se apossar de todo o plano de nossas vidas, propomos maneiras de se contrapor a tendência hegemônica. Compreendemos que aqui reside a "fissura”, a “fenda” que não permite o círculo capitalista cerrar, e sim, se coloca enquanto barreira a ser transposta pelo próprio capital. Nesse sentido, entendemos a centralidade posta sobre a reprodução das relações de produção, bem como, o espaço enquanto condição e meio da sobrevivência do capitalismo.

A arte, ou as atividades que resvalam nela, contêm uma potência de transformação na medida que restitui um espaço-tempo dedicado à apropriação do espaço. Nela há a latência das transgressões, portanto, temos na arte a arte das transgressões. 


\section{Considerações Finais}

"O investigador urbano não é o agente de transformação social e política. Seu papel fundamental reside na produção crítica de conhecimento na acepção mais forte e rigorosa do termo. Seu papel é ser subversivo, isto é, revolver, perturbar, desordenar o estado das coisas e idéias, transtornando a interpretação consagrada, a ação tida como correta ou eficaz, a hierarquia dos valores e a racionalidade dominante. Subverter significa questionar e desvendar as práticas sociais dos mais variados grupos presentes ao longo das hierarquias da sociedade, com especial atenção para os múltiplos valores, símbolos, tradições e experiências dos inúmeros componentes das camadas populares.

A investigação subversiva pode e deve produzir preciosas matérias-primas para se atingir o socialmente desejável."

Lucio Kowarick

Acreditamos que o papel do pesquisador é refletir e polemizar as interpretações sobre os processos sociais. É com este foco que a pesquisa se desenrolou, refletindo e polemizando sobre a produção de um lugar, que na aparência, se mostra como uma resistência à degradação da vida, mas escamoteia as formas de dominação do espaço para a realização da reprodução das relações de produção sob o prisma da acumulação.

Na pesquisa, o intuito era debater as resistências e transgressões na metrópole paulistana, porém, no desenvolvimento da problemática nos deparamos com alguns desafios, um de âmbito teórico e outro do plano da realidade. Em relação à prática sócioespacial constatamos as formas sutis de dominação do espaço pela legitimidade dada por meio da propriedade da terra e pelo modo de gestão dos serviços existentes no lugar. No âmbito teórico, percebemos uma produção pautada nas organizações populares institucionalizadas legitimando-as, também, como as formas mais eficazes, atualmente existentes, para as conquistas diante à urbanização capitalista. Este fato, então, nos fez perceber a dificuldade de encontrar, na interpretação teórica, os fundamentos das alienações que perpassam as formas de organização e mobilização popular no espaço urbano. O que descobrimos foi a centralidade do espaço na realização das estratégias da prática sócioespacial e o total obscurecimento deste mesmo espaço no plano do pensamento.

Por isso, ao nos debruçarmos sobre a territorialização de um sujeito que possui papel central na produção do lugar encontramos a via necessária e potente de retirar o espaço de

\footnotetext{
${ }^{1}$ Kowarick, Lucio “Investigação Urbana e Sociedade: Comentários sobre Nuestra América” pg. 132 In: "Escritos Urbanos"
} 
sua aparência de transparência e dar a ele a devida importância quanto à reprodução da sociedade em sua totalidade. É este mesmo espaço que ora aparece profundamente normatizado pelas instituições, que também contêm as transgressões, sendo fundamental para as estratégias de classe.

As perspectivas abertas foram de entender que o espaço é elemento essencial para a reprodução das relações de produção e, que com uma urbanização que leva a cabo o aprofundamento das desigualdades vistas pelo processo de segregação sócio-espacial, a instituição de normas, principalmente, nos lugares nos quais as tensões estão mais latentes, como na periferia, se torna ação obrigatória. Esta estratégia, sob um manto ideológico, chega na periferia através das milhares instituições territorializadas, espraiando relações de poder que empobrece as relações sociais ao romper com os espaços de sociabilidade pela mediação da representatividade. Compreender o papel destas instituições na periferia se torna fundamental.

Por fim, o rompimento destes espaços de sociabilidade no espaço urbano reforça a tese de que as dificuldades de mobilização e organização popular estão centradas nestas estratégias espaciais. Ao desvendar e retirar do ocultamento o papel do espaço nas estratégias de dominação, nos permite construir coletivamente um projeto que tenha como referência o direito à cidade. Isto é, o direito de reconstruir os espaços de sociabilidade, o espaço-tempo do usufruir da convivência com o outro e construir os laços de solidariedade, que estão sendo empobrecidos neste processo de urbanização regido pelo valor-de-troca.

Antes de mais nada, as considerações finais tem o papel de apontar caminhos que poderão ser trilhados a partir das proposições postas pelas reflexões aqui contidas e que somadas aos debates decorrentes das idéias apresentadas poderão expor o espaço como elemento central neste momento da reprodução capitalista. 


\section{Bibliografia}

- AVRITZER, Leonardo (org.), A participação em São Paulo, Unesp, São Paulo, 2004.

- BAVA, Silvio Angrisani Caccia, Práticas Cotidianas e Movimentos Sociais: elementos para reconstituição de um objeto de estudo, dissertação de mestrado, FFLCH-USP, São Paulo, 1983.

- $\quad$ BENSAID, Daniel, Cambiar el mundo, Catarata, Madri, 2004.

- BOTELHO, Adriano, O financiamento e a financeirização do setor imobiliário: Uma análise da produção do espaço e da segregação sócio-espacial através do estudo do mercado da moradia na cidade de São Paulo, tese de doutorado, Faculdade de Filosofia, Letras e Ciências Humanas - Departamento de Geografia - USP, São Paulo, 2005.

- BRANDÃO, Carlos Rodrigues, Pesquisar-Participar, In: Pesquisa Participante, BRANDÃO, C. R.(org.), Editora Brasiliense, São Paulo, 1981.

- CARLOS, A. F. A. \& CARRERAS, C., Urbanização e Mundialização: Estudos sobre a metrópole, Contexto, São Paulo, 2004.

- CARLOS, Ana Fani Alessandri, A (re)produção do espaço urbano, Edusp, São Paulo, 1994.

- CARLOS, Ana Fani Alessandri, Espaço - tempo na metrópole, Contexto, São Paulo, 2001.

- CARLOS, Ana Fani Alessandri, O espaço urbano: Novos escritos sobre a cidade, Contexto, São Paulo, 2004.

- CARLOS, Ana Fani Alessandri, O lugar no/do mundo, Hucitec, São Paulo, 1996.

- CHOSSUDOVSKY, Michel, A Globalização da pobreza: impactos das reformas do FMI e do Banco Mundial, Moderna, São Paulo, 1999.

- COÊLHO, Maria Nelma Gomes, A Urbanização da Favela Autódromo, 1983 a 1996: decisão, ação e conflito, dissertação de mestrado, FFLCH - USP, São Paulo, 2002.

- COELHO, Simone de Castro Tavares, O Estado e os movimentos pró moradia: A construção de uma relação democrática, dissertação de mestrado, FFLCHUSP, São Paulo, 1002. 
- CRAEMER, Ute, Crianças: entre luzes e sombras - Experiência pedagógica na Favela Monte Azul, Associação Comunitária Monte Azul, São Paulo, (s/d).

- D’Alessandro, Maria Lucia Salum, Avaliação da Política de Urbanização de Favelas em São Paulo no período de 1989/1992, dissertação de mestrado, Fundação Getúlio Vargas, São Paulo, 1999.

- DAMIANI, Amélia Luisa, A cidade (des)ordenada: Concepção e Cotidiano do Conjunto Habitacional Itaquera I, tese de doutorado, Departamento de Geografia - USP, São Paulo, 1993.

- DAMIANI, Amélia Luisa, A propósito do espaço e do urbano. Algumas hipóteses, In: Revista Cidades, Grupo de Estudos Urbanos, vol. 01, Presidente Prudente, 2004.

- DAMIANI, Amélia Luisa, O lugar e a produção do cotidiano, In: Novos Caminhos da Geografia, Carlos, A. F.(org), Contexto, São Paulo, 1999.

- DAMIANI, Amélia Luisa, Urbanização crítica e situação geográfica a partir da metrópole de São Paulo, In: Carlos, A. F. C. \& Oliveira, A. U., Geografias de São Paulo: Representação e Crise da Metrópole, contexto, São Paulo, 2004.

- DAMIANI, Amélia, A crise da cidade: os termos da urbanização, In:Carlos, A. F. A., Daminai, A., Seabra, O. L. S., O espaço no fim do século: a nova raridade, Geousp Abordagens, Contexto, São Paulo, 1999.

- DAVIS, Mike, Planeta Favela, Boitempo, São Paulo, 2006.

- DENALDI, Rosana, Políticas de Urbanização de Favelas: Evolução e Impasses, tese de doutorado, Faculdade de Arquitetura e Urbanismo - USP, São Paulo, 2003.

- DOIMO, Ana Maria, A Vez e a Voz do Popular: Movimentos sociais e participação política no Brasil pós-70, Relume Damará, Rio de Janeiro, 1995.

- ESTEBANEZ, Jose, Tendências y problemáticas actual de la Geografia, Editora Cicel, s/data.

- FELDMAN, Sarah (edição) e CYMBALISTA, Renato (colaboração), A pesquisa sobre segregação: conceitos, métodos e medições, Debate, Revista Espaço e Debates: Segregações Urbanas, n45, São Paulo, 2004.

- FERNANDES, Bernardo Mançano, MST: Formação e Territorialização, Editora Hucitec, São Paulo, 1999. 
- FERREIRA, Genovan Pessoa de Moraes, Morro da Conceição:espaço e cotidiano do lugar, In: Revista Geousp:Espaço e Tempo, nº8, Departamento de Geografia da Universidade de São Paulo, São Paulo, 2000.

- FIGUEIREDO, Regina, Saúde sexual e reprodutiva de mulheres de baixa renda: Favela Monte Azul - um estudo de caso, dissertação de mestrado, FFLCH USP, São Paulo, 1999.

- GOHN, Maria da Glória, Classe Populares, Periferia Urbana e Movimento Social Urbano: o movimento das sociedades amigos de bairro em São Paulo, FFLCH-USP, São Paulo, 1979.

- GOHN, Maria da Glória, História dos movimentos e lutas sociais: A construção da cidadania dos brasileiros, Edições Loyola, São Paulo, 1995.

- GOHN, Maria da Glória, Os sem terra, ONGs e Cidadania, Cortez Editora, São Paulo, 1997.

- HARVEY, David, Los limites Del capitalismo y la teoria marxista, Fondo de Cultura Econômica, México, 1990.

- HOBSBAWM, Eric, Era dos Extremos: o breve século XX - 1914 - 1991, Companhia das Letras, São Paulo, 1994.

- HONNETH, Axel, Luta por reconhecimento: A gramática moral dos conflitos sociais, Editora 34, São Paulo, 2003.

- LEFEBVRE, Henri, A re-produção das relações de produção, Publicações Escorpião, Porto, 1978.

- LEFEBVRE, Henri, A Revolução Urbana, trad. Sérgio Martins, Editora UFMG, Belo Horizonte, 2002.

- LEFEBVRE, Henri, A vida cotidiana no mundo moderno, trad. Alcides de Barros, Editora Ática, Série Temas, São Paulo, 1991.

- $\quad$ LEFEBVRE, Henri, Direito a Cidade,Editora Morales, São Paulo 1991.

- LEFEBVRE, Henri, Espacio y Política: El derecho a la ciudad II, Ediciones Península, Barcelona, 1976.

- MARICATO, Ermínia (org.), A produção capitalista da casa (e da cidade) no Brasil industrial, Editora Alfa-Omega, São Paulo, 1982.

- MARQUES, Eduardo e Torres, Haroldo (org.), São Paulo: Segregação, Pobreza e Desigualdades Sociais, Editora Senac, São Paulo, 2005. 
- MARTES, Ana Cristina Braga, A institucionalização dos movimentos de reivindicação urbana: As secretarias de saúde e a participação popular(1979 1989), dissertação de mestrado, FFLCH - USP, São Paulo, 1990.

- MARTINS, José de Souza, A sociedade vista do abismo: novos estudos sobre exclusão, pobreza e classes sociais, Ed. Vozes, Petrópolis, 2003.

- MARTINS, José de Souza, Depoimento, Revista Espaço e Debates: Periferia Revisitada, n²42, São Paulo, 2001.

- MARTINS, José de Souza, O senso comum e a vida cotidiana, In: A sociabilidade do homem simples, Hucitec, São Paulo, 2000.

- MARTINS, José de Souza, Sobre o modo capitalista de pensar, Coleção Ciências Sociais, Hucitec, São Paulo, 1982.

- MELUCCI, Alberto, A Invenção do presente - movimentos sociais nas sociedades complexas, Editora Vozes, Petrópolis, 2001

- MEREGE, Luiz Carlos, Análise de formações comunitárias em favelas Metodologia, perspectivas e resultados - o modelo da Associação Monte Azul, Fundação Getúlio Vargas, São Paulo, 2001

- MOURA, Rosa e ULTRAMARI, Clovis, O que é Periferia Urbana?, Coleção Primeiros Passos, Ed. Brasiliense, São Paulo, 1996.

- PALlAMin, Vera M. (org.), Cidade e Cultura: esfera pública e transformação urbana, Editora Estação Liberdade, São Paulo, 2002.

- PEDON, Nelson Rodrigo, A participação popular na produção do espaço urbano da cidade de Araçatuba - São Paulo: o caso do Bairro Alvorada, dissertação de mestrado, FCT - Unesp, Presidente Prudente, 2005.

- PEQUENO, L. R. B. \& Taschner, S. Avaliação de programas de urbanização de favelas da cidade de São Paulo: Estudo de caso Favela Autódromo, In: Desafios da Cidade Informal - Evento Preparatório da Conferência Habitat II, Belo Horizonte, 1995.

- RIBEIRO, Vânia Moura, Jardim Icaraí: Desenho urbano na periferia de São Paulo, Dissertação de mestrado, Faculdade de Arquitetura e Urbanismo - USP, São Paulo, 1996.

- $\quad$ ROCHA, Alexandre Souza de, Centralidade e Periferia na Grande São Paulo: abordagem crítica sobre o morar na periferia da metrópole, dissertação de mestrado, Departamento de Geografia - USP, São Paulo, 2000. 
- ROCHA, Alexandre Souza de, Espaço e política na centralidade da periferia, In: O espaço no fim do século: a nova raridade, CARLOS, A. F. C., DAMIANI, A. L. E SEABRA, O. C. L., Contexto, São Paulo, 1999.

- RODRIGUES, Arlete Moyses, Na procura do lugar o encontro da identidade: Um estudo do processo de ocupação coletiva de terra para moradia - Osasco, tese de doutorado, Faculdade de Filosofia, Letras e Ciências Humanas Departamento de Geografia - USP, São Paulo, 1988.

- SADER, Eder, Quando novos personagens entraram em cena: experiências e lutas dos trabalhadores da grande São Paulo - 1970-1980, Paz e Terra, São Paulo, 1988.

- SANTOS, Milton , Metrópole Corporativa Fragmentada: O caso de São Paulo, Secretaria do Estado da Cultura, Nobel, São Paulo, 1990.

- $\quad$ SANTOS, Milton, O espaço do cidadão, Nobel, São Paulo, 1987.

- SANTOS, Milton, A Natureza do espaço: Técnica e Tempo. Razão e Emoção, Edusp, São Paulo, 2002.

- SANTOS, Milton, A Urbanização Brasileira, Editora Edusp, São Paulo, $5^{\circ}$ Edição, 2005.

- SEABRA, O.L., Urbanização e Fragmentação: Cotidiano e vida de bairro na metamorfose da cidade em metrópole, a partir das transformações do Bairro do Limão, tese de livre-docência, FFLCH-USP, São Paulo, 2003.

- SEABRA, Odette Carvalho de Lima, Insurreição do Uso, In: Henri Lefebvre e o retorno à dialética, MARTINS, J. S.(org.), Hucitec, São Paulo, 1996.

- SEABRA, Odette Carvalho de Lima, São Paulo: a cidade, os bairros e a periferia, In: Geografias de São Paulo: Representação e crise da Metrópole, CARLOS, A. F. A. e OLIVEIRA, A. U. (org.), Contexto, São Paulo, 2004.

- SEABRA, Odette Carvalho de Lima, Territórios do uso: cotidiano e modo de vida, In: Revista Cidades, Grupo de Estudos Urbanos, vol. 02, Presidente Prudente, 2004.

- SILVA, Flávia Elaine da, Favela, que negócio é este?Um estudo sobre o projeto de urbanização da favela do Jaguaré no contexto dos negócios urbanos e de sua reprodução crítica, dissertação de mestrado, , Faculdade de Filosofia, Letras e Ciências Humanas - Departamento de Geografia - USP, São Paulo, 2006. 
- SILVA, José Borzacchiello da, Movimentos Sociais Populares em Fortaleza: Uma abordagem geográfica, tese de doutorado, Faculdade de Filosofia, Letras e Ciências Humanas - Departamento de Geografia - USP, São Paulo, 1986.

- SOUZA, Marcelo José Lopes de, O que pode o ativismo de Bairro? Reflexão sobre as limitações e potencialidades do ativismo de bairro à luz de um pensamento autonomista, dissertação de mestrado, UFRJ - IG, Rio de Janeiro, 1988.

\section{Material Cartográfico}

Fotografias Aéreas dos anos de 1962, 1972 e 1994 adquiridas no Laboratório de Sensoriamento Remoto - AFA do Departamento de Geografia da USP.

\section{Documentos Consultados}

- Relatórios do Projeto de Urbanização de Favela - Favela Monte Azul - APOIO Assessoria Profissional de Apoio ao Movimento Popular, 1998 - 2002,

- Relatório de Avaliação de Risco - Favela Monte Azul, Programa de Urbanização de Favelas do município de São Paulo, RC - SP - 056/93, BUREAU de Projetos e Consultoria Ltda, setembro, 1993.

- Relatório de Reavaliação das Situações de Risco - Favela Monte Azul, Programa de Urbanização de Favelas do município de São Paulo, RC - SP 022/95, BUREAU de Projetos e Consultoria Ltda, fevereiro, 1995.

- Documentos referentes aos aditamentos, processos de pagamentos de parcelas, avaliação quanto a canalização do córrego, processo n 335/95 COHAB - SP.

- Programação das atividades culturais e fóruns de debate.

- Folderes com resumo dos trabalhos da Associação Comunitária Monte Azul.

- Estatuto Social da Associação Comunitária Monte Azul, novembro, 2003.

- Resumo Geral das Áreas de Atuação da Associação Comunitária Monte Azul, 2006.

- Convênio que Entre Si Celebram O Fundo de Atendimento à População Moradora em Habitação Subnormal - FUNAPS e a Associação Comunitária Monte Azul, Prefeitura de São Paulo, Governo Luiza Erundina, São Paulo, dezembro, 1992.

- Ata da Assembléia da Diretoria da Associação Comunitária Monte Azul, São Paulo, março, 2001. 


\section{Jornais e Sites}

Folha de São Paulo

Estado de São Paulo

O Diário (Mogi das Cruzes)

www.sab.org.br (Sociedade Antroposófica no Brasil)

www.monteazul.org.br (Associação Comunitária Monte Azul) 


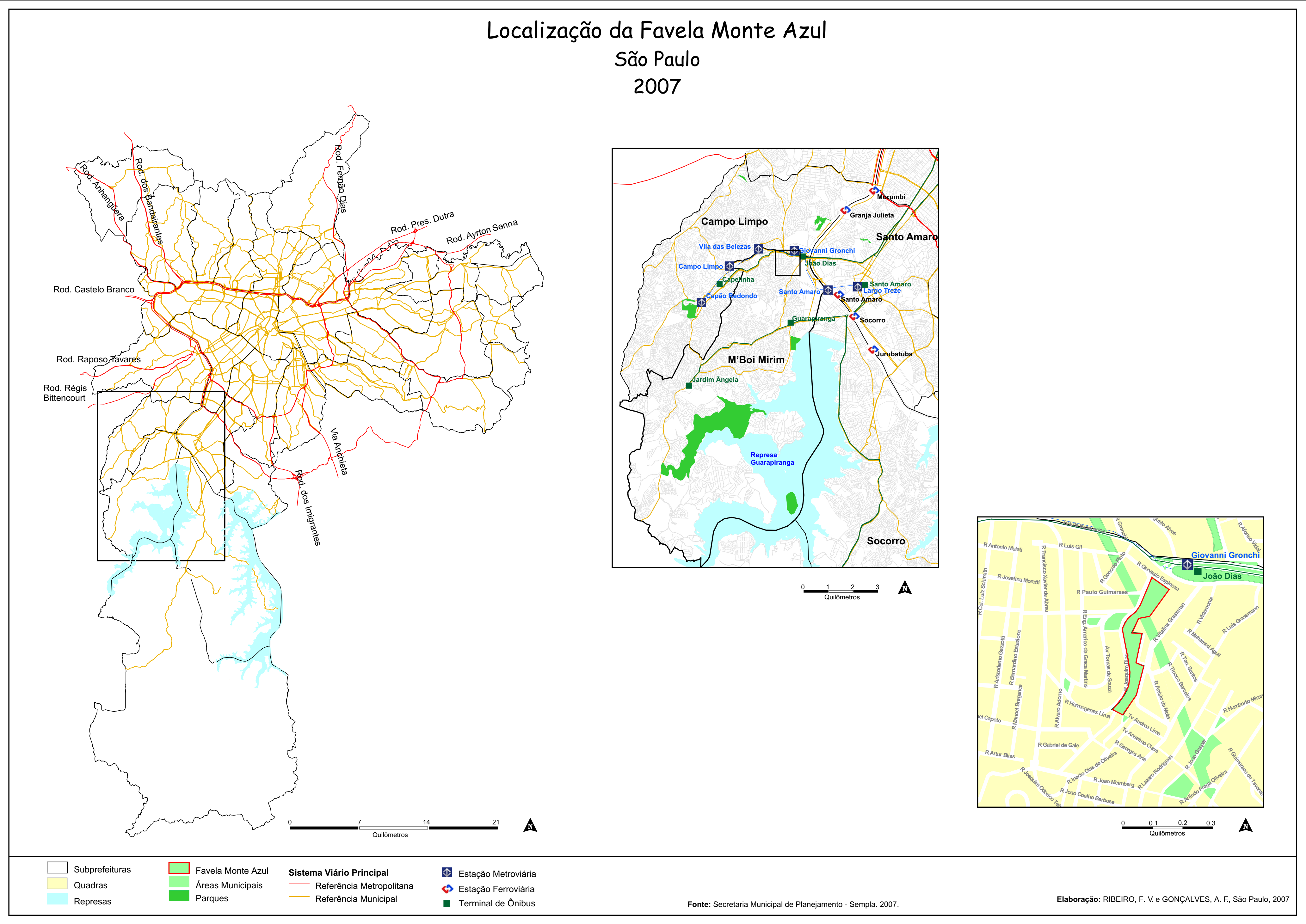


Territorialização da Associação Comunitária Monte Azul 2007

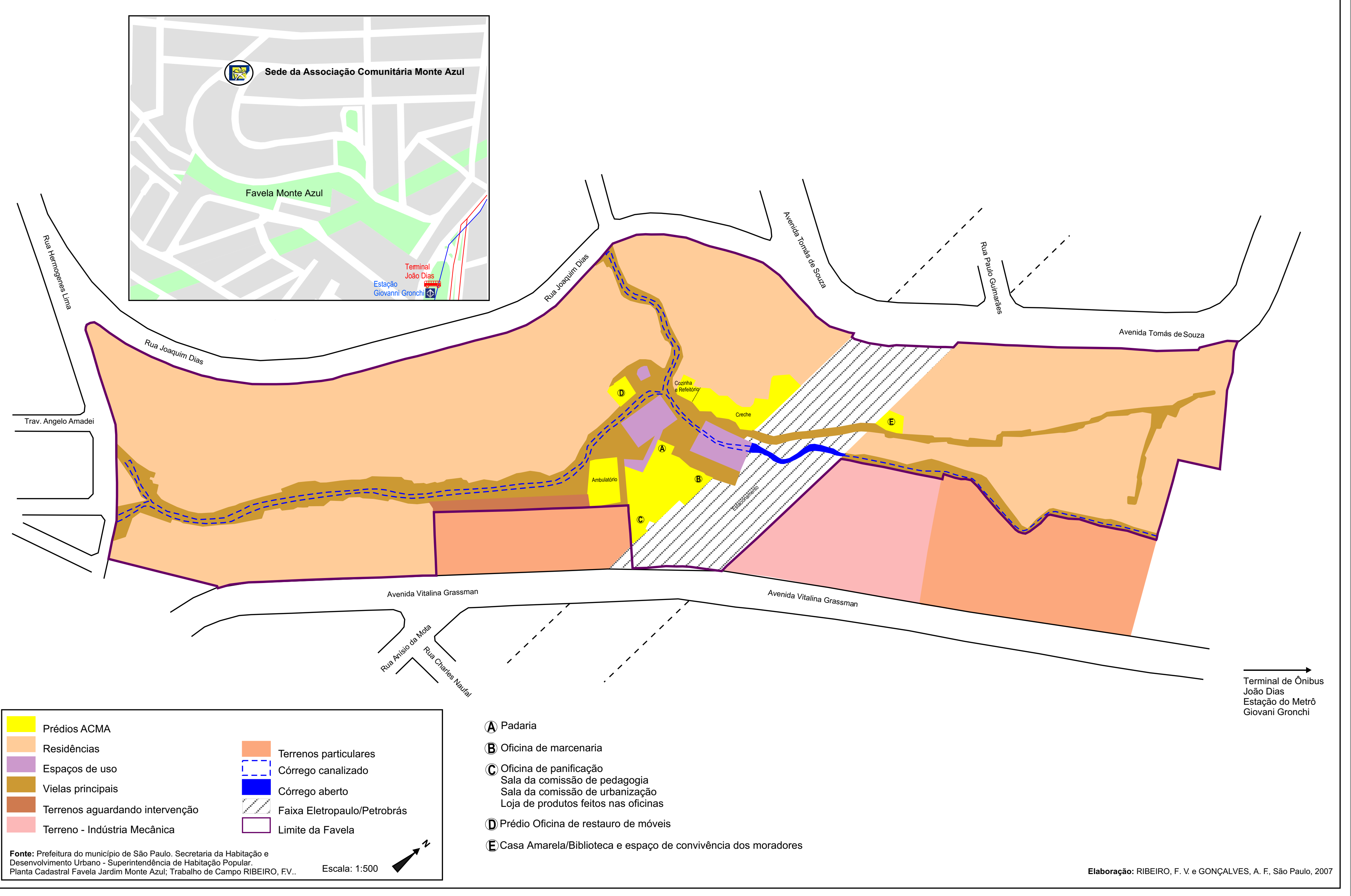




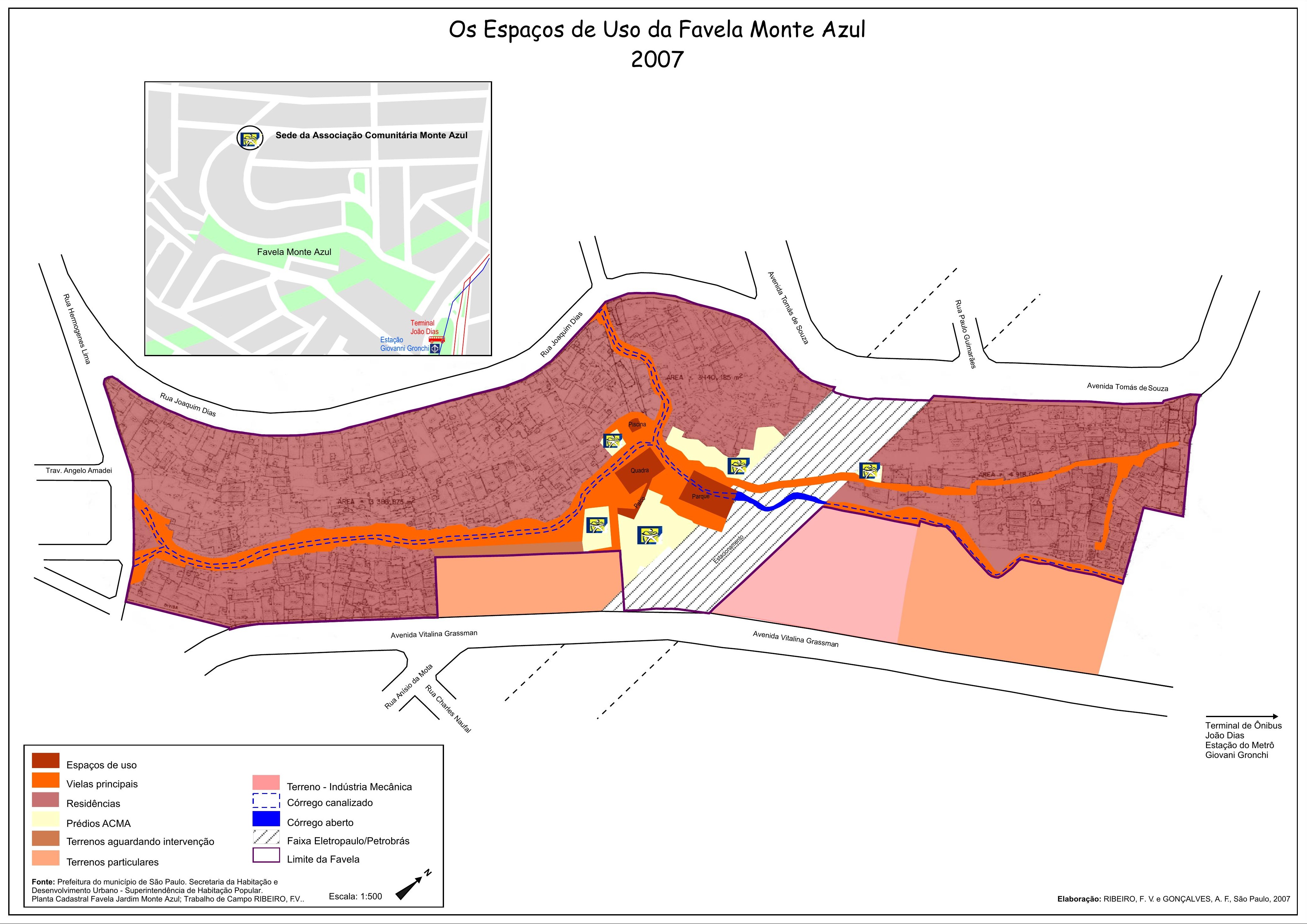




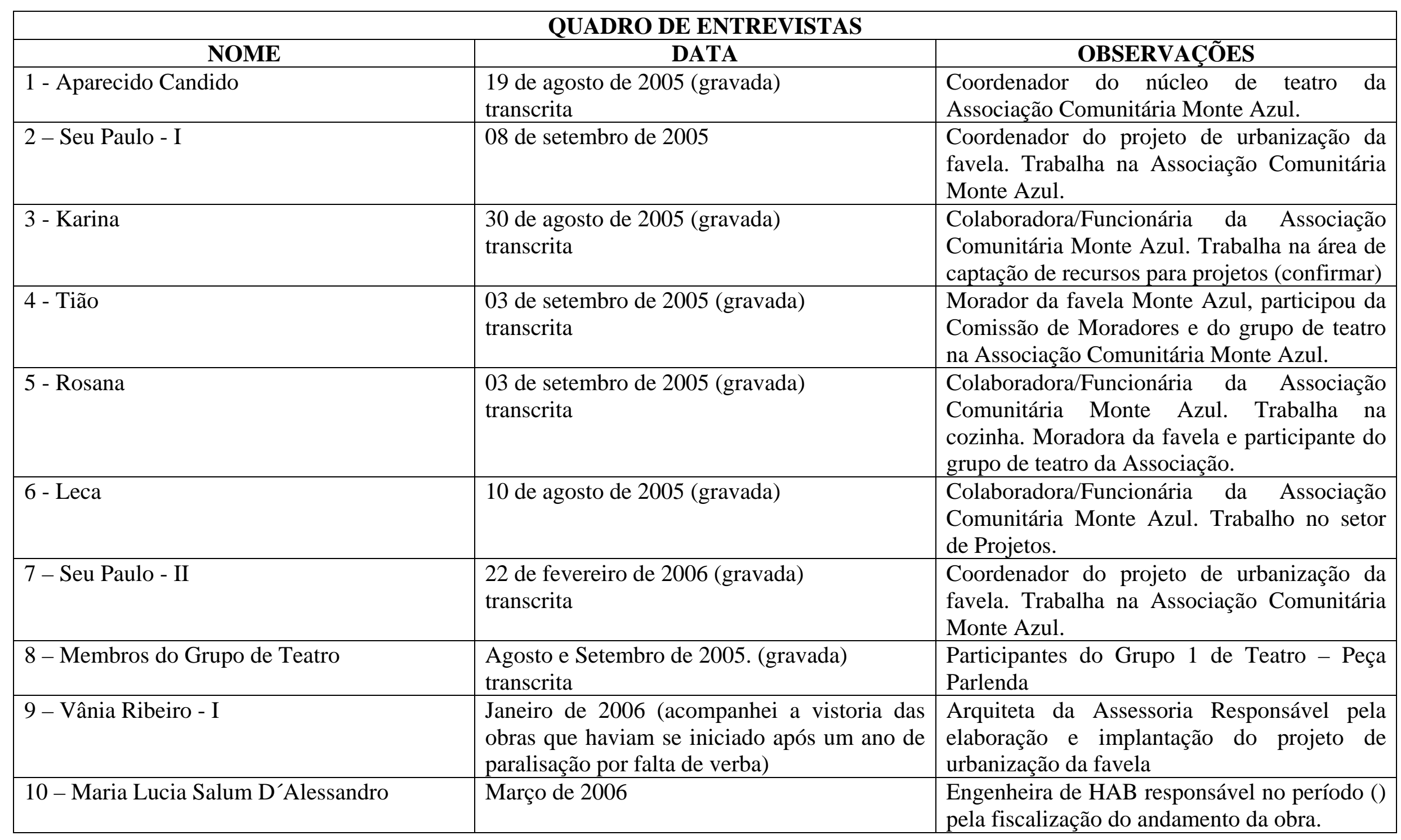




\begin{tabular}{|l|l|l|}
\hline $\begin{array}{l}11 \text { - Comissão de Jovens - Eraldo e Nenê } \\
\text { (Benício) }\end{array}$ & 3 de novembro de 2005 & $\begin{array}{l}\text { Moradores da Favela e integrantes da } \\
\text { Comissão de Jovens formada para se tornar a } \\
\text { comissão de moradores. O primeiro estava } \\
\text { desempregado e o segundo trabalhando como } \\
\text { pedreiro na construção do novo prédio da } \\
\text { Oficina de Restauro de Móveis. }\end{array}$ \\
\hline 12 - Valéria Carrillo & $\begin{array}{l}\text { Co de março de 2006. (gravada) } \\
\text { transcrita }\end{array}$ & $\begin{array}{l}\text { Coordenadora da área de Desenvolvimento } \\
\text { Institucional da ACMA. Trabalha desde 2001 }\end{array}$ \\
\hline 13 - Vânia Ribeiro - II & $\begin{array}{l}18 \text { de outubro de 2006 (gravada) } \\
\text { transcrita }\end{array}$ & $\begin{array}{l}\text { Arquiteta da Assessoria Responsável pela } \\
\text { elaboração e implantação do projeto de } \\
\text { urbanização da favela }\end{array}$ \\
\hline 14 - Claudio & $\begin{array}{l}05 \text { de outubro de 2006. (gravada) } \\
\text { Transcrita }\end{array}$ & $\begin{array}{l}\text { Morador da Favela Monte Azul e assessor do } \\
\text { deputado Vicente Cândido (PT) }\end{array}$ \\
\hline 15 - Lourdes e sua filha Neide & $\begin{array}{l}08 \text { de abril de 2006 (gravada) } \\
\text { transcrita }\end{array}$ & $\begin{array}{l}\text { Primeira moradora da Favela Monte Azul. } \\
\text { Não tem ligação com a ACMA }\end{array}$ \\
\hline
\end{tabular}

